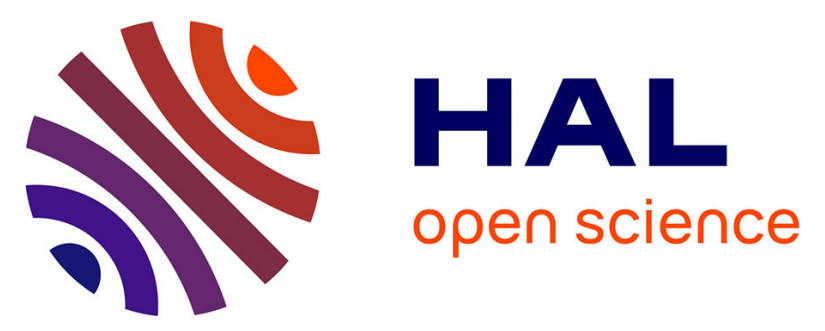

\title{
Highly Siderophile Element and Os Isotope Systematics of Volcanic Rocks at Divergent and Convergent Plate Boundaries and in Intraplate Settings
}

Abdelmouhcine Gannoun, Kevin W. Burton, James M.D. Day, Jason Harvey, Pierre Schiano, Ian Parkinson

\section{To cite this version:}

Abdelmouhcine Gannoun, Kevin W. Burton, James M.D. Day, Jason Harvey, Pierre Schiano, et al.. Highly Siderophile Element and Os Isotope Systematics of Volcanic Rocks at Divergent and Convergent Plate Boundaries and in Intraplate Settings. Reviews in Mineralogy and Geochemistry, 2015, 81 (1), pp.651 - 724. 10.2138/rmg.2016.81.11 . hal-01637163

\section{HAL Id: hal-01637163 \\ https://hal.uca.fr/hal-01637163}

Submitted on 31 Mar 2021

HAL is a multi-disciplinary open access archive for the deposit and dissemination of scientific research documents, whether they are published or not. The documents may come from teaching and research institutions in France or abroad, or from public or private research centers.
L'archive ouverte pluridisciplinaire HAL, est destinée au dépôt et à la diffusion de documents scientifiques de niveau recherche, publiés ou non, émanant des établissements d'enseignement et de recherche français ou étrangers, des laboratoires publics ou privés. 


\section{UNIVERSITY OF LEEDS}

This is a repository copy of Highly Siderophile Element and Os Isotope Systematics of Volcanic Rocks at Divergent and Convergent Plate Boundaries and in Intraplate Settings.

White Rose Research Online URL for this paper:

http://eprints.whiterose.ac.uk/102470/

Version: Accepted Version

\section{Article:}

Gannoun, A, Burton, KW, Day, JMD et al. (3 more authors) (2016) Highly Siderophile Element and Os Isotope Systematics of Volcanic Rocks at Divergent and Convergent Plate Boundaries and in Intraplate Settings. Reviews in Mineralogy and Geochemistry, 81 (1). pp. 651-724. ISSN 1529-6466

https://doi.org/10.2138/rmg.2016.81.11

(C) 2016, Mineralogical Society of America. This is an author produced version of a paper published in Reviews in Mineralogy and Geochemistry. Uploaded in accordance with the publisher's self-archiving policy.

\section{Reuse}

Unless indicated otherwise, fulltext items are protected by copyright with all rights reserved. The copyright exception in section 29 of the Copyright, Designs and Patents Act 1988 allows the making of a single copy solely for the purpose of non-commercial research or private study within the limits of fair dealing. The publisher or other rights-holder may allow further reproduction and re-use of this version - refer to the White Rose Research Online record for this item. Where records identify the publisher as the copyright holder, users can verify any specific terms of use on the publisher's website.

\section{Takedown}

If you consider content in White Rose Research Online to be in breach of UK law, please notify us by emailing eprints@whiterose.ac.uk including the URL of the record and the reason for the withdrawal request. 
2 Highly siderophile element and Os isotope systematics of

6 volcanic rocks at divergent and convergent plate boundaries and in intraplate settings

\section{Abdelmouhcine Gannoun ${ }^{1}$, Kevin W. Burton², James M.D. Day ${ }^{3}$, Jason Harvey ${ }^{4}$, Pierre Schiano $^{1}$, Ian Parkinson ${ }^{5}$}

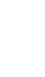

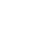

${ }^{1}$ Laboratoire Magmas et Volcans, Université Blaise Pascal, CNRS-IRD, BP 10448, 63000 Clermont Ferrand, France M.Gannoun@opgc.univ-bpclermont.fr

${ }^{2}$ Department of Earth Sciences, Durham University, Science Labs, Durham DH1 3LE, United Kingdom kevin.burton@durham.ac.uk

${ }^{3}$ Geosciences Research Division, Scripps Institution of Oceanography, La Jolla, CA 92093-0244, USA jmdday@ucsd.edu

${ }^{4}$ Institute of Geophysics and Tectonics, School of Earth and Environment, University of Leeds Leeds, LS2 9JT, United Kingdom feejh@leeds.ac.uk

${ }^{5}$ School of Earth Sciences University of Bristol

Bristol BS8 1RJ, United Kingdom Ian.Parkinson@bristol.ac.uk 
Terrestrial magmatism is dominated by basaltic compositions. This definition encompasses mid-ocean ridge basalts (MORB), which account for more than eighty percent of Earth's volcanic products and which are formed at divergent oceanic plate margins; intraplate volcanic rocks such as ocean island basalts (OIB), continental flood basalts (CFB) and continental rift-related basalts, and highly magnesian ultramafic volcanic rocks that dominantly occur in Archean terranes, termed komatiites. All of these broadly basaltic rocks are considered to form by partial melting of the upper mantle, followed by extraction from their source regions and emplacement at the Earth's surface. For these reasons, basalts can be used to examine the nature and extent of partial melting in the mantle, the compositions of mantle sources, and the interactions between Earth's crust and mantle. Because much of Earth's mantle is inaccessible, basalts offer some of the best 'proxies' for examining mantle composition, mantle convection and crust-mantle interactions. By contrast, at arcs, volcanism is dominated by andesitic rock compositions. While some arcs do have basaltic and picritic magmatism, these magma types are rare in convergent plate margin settings and reflect the complex fractional crystallization and often associated concomitant assimilation processes occurring in arc settings. Despite the limited occurrence of high $\mathrm{MgO}$ magmas in arc volcanics, magmas from this tectonic setting are also important for elucidating the behavior of the HSE from creation of basaltic compositions at mid-ocean ridges to the subduction of this crust beneath arcs at convergent plate margins.

The highly siderophile elements (HSE; comprising Re and Au, along with the six platinumgroup elements [PGE] Os, Ir, Ru, Rh, Pt and Pd) combined with the ${ }^{187} \mathrm{Re}^{188} \mathrm{Os}$ and ${ }^{190} \mathrm{Pt}-{ }^{186} \mathrm{Os}$ systems that are embedded within these elements, have found significant utility in the study of basaltic rocks (e.g., Shirey \& Walker, 1998; Carlson, 2005; Day, 2013). The greatest strengths of the HSE lie in the fact that they strongly partition into metal or sulfide phases, and so record evidence for processes that are not revealed from other isotope systems commonly used in high-temperature geochemical studies (e.g., He-O-Sr-Nd-Hf-Pb). Partial melting over much of Earth's geological history has resulted in significant fractionation of the HSE between the mantle and the crust (oceanic and continental). The HSE show contrasting behavior during melting, with the platinum-PGE (PPGE; $\mathrm{Pt}, \mathrm{Pd}), \mathrm{Re}$ and Au usually behaving as moderately compatible to moderately incompatible elements during melting and crystallisation, and the iridium-PGE (IPGE; Os, Ir and Ru) acting as highly compatible elements (Barnes et al., 1985). The differential response of the HSE to partial melting is demonstrated by differences in both the absolute and relative abundances of the HSE in mantle- 
derived melts and in residual mantle rocks themselves. High degree melts, such as komatiites (e.g. Puchtel et al., 2009) show a smaller enrichment of PPGE over IPGE than relatively lower degree melts, such as MORB (e.g. Rehkämper et al., 1999; Bezos et al., 2005) (Figure 1a). Mantle peridotites often show a complementary depletion of PPGE relative to the IPGE that reflects the degree of melt depletion (Figure 1b), consistent with preferential removal of $\mathrm{Re}>\mathrm{Au}>\mathrm{Pd}>\mathrm{Pt}>\mathrm{Rh}$ $>$ Ir $\geq \mathrm{Ru} \geq$ Os (Pearson et al., 2004; Becker et al., 2006; Fischer-Gödde et al., 2011). In the broadest sense, these observations suggest that the HSE in mantle and mantle-derived melts are controlled by both: (i) the degree of melting and; (ii) the mineralogy of mantle rocks. The IPGE are preferentially retained in mantle rocks at low-degrees of melting, consequently, moderate- to low-degree melts such as MORB have relatively low IPGE abundances.

Furthermore, because Pt is moderately compatible, Re is moderately incompatible and Os is highly compatible during melt generation, the Re-Os and Pt-Os isotope systems differ significantly from other geologically useful long-lived radiometric systems (e.g., Rb-Sr, Sm-Nd, Lu-Hf, U-Th-Pb), where both the parent and the daughter elements are preferentially concentrated into the melt. In this chapter, we review the distribution of the HSE amongst mantle minerals and their behavior during melting, the HSE abundances and Os isotope compositions preserved at mid-oceanic ridge settings (divergent plate boundaries), intraplate settings and of magmas formed at arcs (convergent plate boundaries), to examine the behavior of these elements in a range of tectonic settings.

\section{HIGHLY SIDEROPHILE ELEMENT DISTRIBUTION AND BEHAVIOR IN} THE UPPER MANTLE

\section{Core formation and the late accretion of impactor material.}

The HSE have high affinity for both Fe-metal and sulfide over coexisting silicate minerals or silicate melt. Low-pressure metal-silicate partition coefficients determined experimentally are extremely high (between $10^{4}$ and $10^{15}$ ) (Kimura et al., 1974; Jones and Drake, 1986; Peach et al., 1990, 1994; Fleet et al., 1991, 1996; Borisov et al., 1994; O'Neill et al., 1995; Holzheid et al., 2000; Ertel et al., 2001; Fortenfant et al., 2003; Yokoyama et al., 2009; Mann et al., 2012; Brenan et al., 2015, this volume). Consequently, these elements should have been substantially partitioned into Earth's metallic core, leaving the silicate mantles effectively stripped of the HSE. Yet, HSE concentrations in Earth's upper mantle are much greater than predicted from low-pressure experimental data (see Day et al., 2015, this volume). Moreover, their relative abundances display a 
broadly chondritic pattern, rather than reflecting differences in their respective metal-silicate partition coefficient (Figure 2). However, the siderophile behavior of some HSE may be greatly reduced at high pressure-temperature conditions, and on this basis it has been suggested that high-pressure equilibration at the base of a deep molten silicate layer or 'magma ocean' on the early Earth, may account for their abundances in the upper mantle (Murthy, 1991). High-pressure experiments that simulate the conditions of core formation do indeed indicate that the HSE are less siderophile under these conditions (e.g. Mann et al., 2012). However, the range of HSE partition coefficients, even at elevated P-T conditions, cannot account for either the absolute or relative abundances in the terrestrial mantle, suggesting that high-pressure equilibration was not the dominant process controlling their present distribution. Therefore, mantle HSE abundances have long been taken to suggest that between $0.5 \%$ and $0.8 \%$ by mass of 'late accreted' broadly-chondritic material was added to Earth after core formation was complete (e.g., Kimura et al., 1974; Chou, 1978). Differing absolute abundances, but similar chondrite-relative HSE abundances have also been inferred for the Moon, Mars and other meteorite parent-bodies (Day et al., 2007, 2010a, 2012, 2015 this volume; Day \& Walker, 2015; Brandon et al., 2012; Dale et al., 2012a; Riches et al., 2012), suggesting that late accretion was a phenomenon common to all terrestrial planets, setting the HSE abundances in planetary mantles. In this way, core formation and late addition of meteorite material are thought to have established the HSE abundance in Earth's silicate mantle, providing a framework for understanding the long-term effects of mantle melting.

\section{Highly siderophile elements in mantle minerals}

The behavior of the HSE during partial melting of the mantle is controlled by their distribution amongst sulfides, platinum group minerals (PGM) and coexisting silicates and oxides in mantle rocks (see also Lorand and Luguet, 2015, this volume; O’Driscoll and González-Jiménez, 2015, this volume; Harvey et al., 2015, this volume; Becker and Dale, 2015, this volume).

Sulfide: In addition to their strongly siderophile behavior the HSEs are also known to be highly chacophile (sulfur-loving) hence it has long been known that sulfide in mantle rocks exerts a dominant control over the behavior of HSE (e.g. Mitchell and Keys, 1981) despite its extremely low abundance (the proportion of sulfide in mantle rocks is though to be in the range 0.0014 to $0.008 \%$,

139 Luguet et al., 2003). The exact magnitude of partitioning of the HSE between sulfide and silicate, however, remains poorly constrained with values ranging from 1000 to $>10^{8}$ (Figure 3) (Peach et al., 
1990; 1994; Fleet et al., 1996; Crocket et al., 1997; Andrews and Brenan, 2002a; Gannoun et al., 2004, 2007; Fonseca et al., 2009; Mungall and Brenan, 2014). At least some of this variation is likely to relate to compositional variations of sulfide and silicate, or the conditions under which equilibration occurred. Values at the low end of the range are usually found in natural occurrences of glass and sulfide (e.g. Gannoun et al., 2004, 2007), while the highest values are indirect estimates based on alloy-sulfide and alloy-silicate partitioning (e.g. Fonseca et al., 2009). A particular problem with the "indirect" estimates of alloy-silicate partitioning (Fonseca et al., 2009) is that they were determined for $\mathrm{Fe}$ and $\mathrm{S}$-free compositions, precluding the possible formation metal-sulfide complexes (e.g. Gaetani and Grove, 1997). Moreover, the solubility of at least some HSE in silicate melts is enhanced in sulfur-bearing experiments, relative to sulfur-free (Laurenz et al., 2013) bringing partition coefficients into the range of other experimental estimates (Andrews and Brenan, 2002a; Mungall and Brenan, 2014). While the differences in partition coefficient that remain still span up to three orders of magnitude, estimates based on individual experiments or natural coexisting sulfidesilicate show significantly less variation. These data indicate that the PGE (Os, Ir, Ru, Pt and Pd) partition similarly into sulfide, with only Re showing a significant difference to the other HSE.

During mantle melting, sulfide will be removed in the silicate melt, as a function of temperature, pressure, oxygen fugacity and the iron content of the melt (Wallace and Carmichael, 1992; Mavrogenes and O'Neill, 1999; O’Neill and Mavrogenes, 2002). Given the estimated sulfur content of both the primitive mantle $\left(250 \pm 50 \mu \mathrm{g} \mathrm{g}^{-1} \mathrm{~S}\right.$; Lorand 1990; O'Neill 1991; Palme and O’Neill 2003) and the depleted mantle ( 120-150 $\mu_{\mathrm{g} \mathrm{g}} \mathrm{g}^{-1} \mathrm{~S}$; Salters and Stracke, 2004), and the relatively low degrees of partial melting required to produce most basalts, it is likely that they leave their source sulfide saturated (that is, sulfide remains as a stable mantle mineral). For example, the low HSE content of some low-degree alkali basalt partial melts can be explained by the presence of residual sulfide in the mantle source, while the high HSE content of high-degree mantle melts, such as komatiites, can be explained by exhaustion of sulfide in the source. However, sulfide behavior alone cannot account for the systematic depletion of HSE seen in mantle rocks, or the variable HSE content and very high Re abundances seen in MORB.

Silicate and oxides: Rhenium not only partitions into sulfide, but also into other mantle phases including clinopyroxene, orthopyroxene, garnet and spinel (Hart and Ravizza, 1996; Mallman and O’Neill, 2007; Righter and Hauri, 1998, Burton et al., 1999, 2000, 2002), particularly under reducing conditions (Mallman and O’Neill, 2007). The relatively low partition coefficients for Re between 
silicate phases and melt, and the much lower coefficient for its partitioning between sulfide and silicate melt compared to other HSE, makes this element moderately incompatible during partial melting (Figure 3). The partitioning of Re into silicate then raises the question of to what degree the HSE may also be incorporated into silicates or oxides in mantle rocks. Overall, natural and experimental data suggest that silicate or oxide phases in the mantle do not exert a strong control on the behavior of HSE during partial melting. Taking estimates of the proportion of silicate phases present in the upper mantle (e.g. Workman and Hart, 2005), partial melting of a sulfide-free mantle would yield melts that are slightly depleted in Os, Ir and Ru, relative to their source. Such a pattern is consistent with that seen for high-degree melts, such as komatiites. Nevertheless, silicate and oxide behavior cannot account for the fractionation of the HSE, and in particular the low Os, Ir and Ru contents, seen in MORB basaltic rocks from all tectonic settings.

Spinel: Empirical estimates of partitioning derived from mineral separates suggest that Os, Ru and Ir are highly compatible in Cr-bearing spinel with partition coefficients of up to 150 , while $\mathrm{Pt}$ and $\mathrm{Pd}$ are moderately compatible (Hart and Ravizza, 1996; Puchtel and Humayun, 2001). Experimental work on spinel-silicate melt partitioning at moderate to high oxygen fugacity suggests that for $\mathrm{Fe}$ bearing spinels $\mathrm{Ru}, \mathrm{Rh}$ and $\mathrm{Ir}$ are all highly compatible with partition coefficients of 20 to > 1000 (Figure 4), whereas Pd is barely compatible (Capobianco and Drake, 1990; Capobianco et al., 1994, Righter et al., 2004). More recently it has been shown that the partition coefficients for $\mathrm{Ir}, \mathrm{Rh}$, and $\mathrm{Ru}$ are strongly controlled by the ferric-iron content of the spinels. For $\mathrm{Cr}$-bearing spinels, in which $\mathrm{Fe}^{3+}$ is replaced by $\mathrm{Cr}^{3+}$, partition coefficients for $\mathrm{Ir}$ and $\mathrm{Rh}$ are much lower than for Fe-rich compositions, and Pt and Pd are highly incompatible (Brenan et al., 2012).

Olivine: Some of the first empirical data for olivine mineral separates were taken to indicate that Os may be compatible in olivine with an inferred olivine-silicate partition coefficient of $\sim 20$ (Figure 4), (Hart and Ravizza, 1996). However, other work on separated olivine suggested that Os is highly incompatible (Walker et al., 1999; Burton et al., 1999, 2000, 2002). At this stage it is not clear whether these variations reflect compositional differences between samples, or simply the presence of micro-nuggets of sulfide or PGMs in the separated silicate phase. Experimental work, however, suggests that many HSE are weakly compatible or only slightly incompatible in olivine, particularly under reducing conditions (Brenan et al., 2003, 2005).

Orthopyroxene and clinopyroxene: Empirical constraints from Hart and Ravizza (1996) suggest that Os may be compatible in orthopyroxene and clinopyroxene (Figure 4), but other studies yield much 
lower Os concentrations for these phases (relative to coexisting sulfide or olivine) (e.g. Burton et al.,

210 1999, 2000). Experimental work indicates that Re may be mildly compatible in ortho- and 211 clinopyroxene under reducing conditions (e.g. Mallman and O’Neill, 2007), but is incompatible 212 under more oxidizing conditions (e.g. Watson et al., 1987; Righter and Hauri, 1998; Righter et al., 213 2004; Mallman and O’Neill, 2007). While Pt and Pd appear to be mildly compatible in clinopyroxene 214 (Hill et al., 2000; Righter et al., 2004).

Overall, natural and experimental data suggest that silicate or oxide phases in the mantle do not exert a strong control on the behavior of HSEs during partial melting. Taking estimates of the proportion of silicate phases present in the upper mantle (e.g. Workman and Hart, 2005) partial melting of a sulfide-free mantle would yield melts that are slightly depleted in Os, Ir and Ru, relative to their source. Such a pattern is consistent with that seen for high-degree melts, such as komatiites (Figure 1a). Nevertheless, silicate and oxide behavior cannot account for the fractionation of HSEs, and in particular the low Os, Ir and Ru contents, seen in basaltic rocks from all tectonic settings (Figure 1a).

Refractory mantle sulfide: For natural magmatic and experimentally produced sulfide the data suggests that while the HSEs are strongly partitioned into this phase there is little fractionation between the elements (with the exception of Re). Mantle sulfides, however, dominantly comprise refractory monosulfide solid solution (MSS) and $\mathrm{Cu}$-rich sulfides, which together control much of the HSE budget of the upper mantle (e.g. Alard et al., 2000). Petrographic observations suggest that MSS often occurs as inclusions trapped in silicate phases, and is characterized by high Os, Ir and $\mathrm{Ru}$ abundances, whereas the interstitial $\mathrm{Cu}$-rich sulfides possess lower Os, Ir and Ru contents (Figure 5). The silicate hosted MSS sulfides were interpreted to be the refractory residues of partial melting, and the interstitial sulfides as having crystallised from a sulfide-bearing melt. On the basis of these observations it has been argued that the fractionation of HSE during mantle melting might be accomplished by partitioning between refractory "solid" MSS and liquid sulfide (Bockrath et al., 2004a). However, at mantle temperatures of $1300-1400^{\circ} \mathrm{C}$ and pressures of $5-16 \mathrm{kbar}$, that is, those appropriate for the generation of MORB (e.g. Klein and Langmuir, 1987) any refractory sulfide is likely to be completely molten well before the peridotitic silicate and oxide phases start to melt (Rhyzenko and Kennedy, 1973; Hart and Gaetani, 2006). Consequently, two phases of sulfide are unlikely to be stable during the melting that produces MORB, consistent with modeled depletion of mantle peridotites where MSS-sulfide melt partitioning cannot explain the observed variations in $\mathrm{Pd}$,

241 Pt and Au (Fisher-Godde et al., 2011). However, under conditions of melting at lower temperatures, 242 for example, due to the presence of volatiles such as $\mathrm{H}_{2} \mathrm{O}$ and at $\mathrm{fO}_{2}$ lower than that at which sulfide 
243 is oxidized to sulfate, MSS fractionation may play a role in generating melts with low Os, Ir and Ru

244 contents (Mungall, 2002, Mungall et al., 2006; Dale et al. 2012b; Botcharnikov et al., 2013)

Os-Ir-Ru metallic alloys: Osmium, Ir and Ru (the IPGE) are not only strongly concentrated in refractory monosulfide solid solution, but also in platinum-group minerals (PGM), which encompass alloys and sulfides where $\mathrm{Ru}$, Os and/or Ir are the major metallic elements. It is clear from the distribution and absolute concentrations of IPGE in PGM (Figure 6) that precipitation and accumulation of such phases should have a profound effect on IPGE/PPGE fractionation (Brenan and Andrews, 2001). In addition, Pt-rich PGM, such as Pt-Ir alloys, have also been found in upper mantle lithologies (Luguet et al., 2007; Lorand et al., 2010). Palladium-rich PGM also exist, which also may contain Pt, but typically $\mathrm{Pd}$ combines with bismuth and/or tellurium to form bismuthotellurides which are thought to be indicators of refertilisation rather than residual to melting (e.g. Lorand et al., 2010). Thus, Os-Ir-Ru and, to a lesser extent, Pt can all be retained by PGM during melting, while 256 Pd is not.

257 Some have argued that PGE-alloys may represent material that was once part of the core, either as a result of incomplete segregation of metal to the core, or due to the entrainment of outer core material into the mantle at the core-mantle boundary (Bird and Weathers, 1975; Bird and Bassett, 1980; Bird et al., 1999). However, recent experimental data suggests that metal originating in the outer core would possess similar concentrations of Os, $\mathrm{Pt}$ and $\mathrm{Re}$, rather than show an enrichment in Ru-Os and Ir (van Orman et al., 2008; Hayashi et al., 2009) likewise any metal trapped in the mantle during core formation (e.g. Mann et al., 2012). The solubility of Os, Ir and Ru is extremely low in silicate melts (e.g. Borisov and Palme, 2000; Brenan et al., 2005). Therefore, it has been argued that Os-Ir-Ru-rich PGM may precipitate directly from a silicate melt, through nucleation on nanoclusters of HSE molecules (Tredoux et al., 1995). Furthermore, on the basis of the high solubility of Ir and $\mathrm{Ru}$ in sulfide melts it has been proposed that crystallisation of Ru-Ir-Os alloys in the presence of a sulfide liquid is unlikely (Brenan and Andrews, 2001). Rather it has been argued that such alloys can only precipitate from a melt that is sulfide-undersaturated (Brenan and Andrews, 2001; Andrews and Brenan 20002b; Bockrath et al., 2004b; Barnes and Fiorentini, 2008).

Together, these observations have been taken to suggest that the relationship between Os-Ir-Ru alloys and refractory sulfides in the mantle is key to understanding the behavior of the HSE during higher degrees of partial melting (e.g. Fonseca et al., 2012), where the removal of sulfur in silicate melts leads to a decrease in the proportion of sulfide in the source. All the while that sulfide remains present the HSE are quantitatively retained, and can reach wt. \% levels in sulfide. However, as soon 
as sulfide has been completely dissolved, Os-Ir-Ru-Pt alloys form in response to lowering of $\mathrm{fS}_{2}$ and diminished metal-sulfide complexation in the silicate melt (Fonseca et al., 2012). Effectively, much of the HSE budget of the mantle, with the exception of Re, remains in the mantle until sulfide has been completely removed, after which time Os-Ir-Ru and Pt are hosted by PGM phases rather than being liberated in a silicate melt. This model is consistent with an increasing number of petrographic observations indicating the presence of PGM phases in melt-depleted mantle peridotite (Luguet et al., 2003, 2007; Pearson et al., 2004; Brandon et al., 2006; Kogiso et al., 2008, Lorand et al., 2010, 2013; Fisher-Gödde et al., 2012).

The degree of partial melting needed to trigger PGM formation will depend on how much sulfur there is in the mantle source at the onset of melting, and is also a result of the solubility of $S$ being inversely proportional to pressure (Mavrogenes and O'Neill, 1999). The mantle that melts to produce MORB is already significantly depleted (e.g. Hofmann, 1997), and the melting occurs at relatively shallow levels (e.g. Klein and Langmuir, 1987). However, there is considerable uncertainty as to the amount of sulfur in the depleted mantle, with estimates ranging down to $\sim 120 \mu \mathrm{g} \mathrm{g}^{-1}$ (Salters and Stracke, 2004) compared to the concentration in primitive "fertile" (unmelted) mantle at $250 \mu \mathrm{g}$ $\mathrm{g}^{-1}$ (Lorand, 1990; O’Neill, 1991; Palme and O'Neill, 2003). Taking the S content of the MORB source mantle to be $120 \mu \mathrm{g} \mathrm{g}^{-1}$, then $15 \%$ melt extraction is needed to exhaust sulfide from the source, and thereby allow the generation of PGM in the mantle residue (Fonseca et al., 2011, 2012; Mungall and Brenan, 2014). While these calculations indicate that even the depleted mantle requires significant degrees of melting to remove sulfide, such melt proportions are well within the range of estimates for the generation of MORB (e.g. Klein and Langmuir, 1987). In this case PGM formation in the upper mantle may be a potential cause for the characteristic depletion of Os, Ir Ru and $\mathrm{Rh}$, relative to Pt and Pd observed in MORB (Figure 7). The absence of significant fractionation of the HSE in komatiites, considered to represent higher-degrees of melting than MORB, suggests that alloys are not stable at the higher pressures and temperatures conditions required for the generation of such melts (cf. Mungall and Brenan, 2014).

Overall, the natural and experimental data for mantle minerals indicates that whenever sulfide is present in the mantle, the HSE are largely retained during partial melting, the exception being $\mathrm{Re}$ that is not as strongly incorporated into sulfide, and is relatively soluble in silicate melts. However, if base metal sulfide is removed from the system during high degrees of melting, at the pressure temperature conditions appropriate for MORB melting, then this will result in the formation of Os-Ir$\mathrm{Ru}$ alloys and/or sulfides. 
313 The major and trace element variations preserved in mid-ocean ridge basalts indicates that their 314 composition has been extensively modified by fractional crystallisation, prior to eruption on the ocean floor (e.g. Klein and Langmuir, 1987). The principal silicate phases involved in the fractional crystallisation that generates MORB are olivine, plagioclase and clinopyroxene (e.g. Klein and Langmuir, 1987; Grove et al., 1993). In general, the more evolved MORB (that is, those with lower $\mathrm{MgO}$ and Ni contents, due to the crystallisation and removal of olivine) possess lower HSE contents (Figure 7). On the basis of early empirical estimates for the partitioning of Os into olivine, this relationship has led some to suggest that the HSE are compatible in this phase and removed from the silicate melt. However, as discussed previously, with the exception of Re, there is little evidence to suggest that the HSE are strongly partitioned into olivine, plagioclase or clinopyroxene (Figure 4).

Most MORB are thought to be sulfur saturated (Wallace and Carmichael, 1992) and sulfide is a ubiquitous phase. Nevertheless, even if MORB melts are sulfur saturated at their source, they are likely to arrive at the surface undersaturated, because the sulfur content at sulfide saturation increases dramatically at lower pressures (e.g. Mavrogenes and O’Neill, 1999). In this case the only viable mechanism by which MORB melts can become sulfur saturated is through extensive fractional crystallisation, driving the residual melt to higher $\mathrm{S}$ contents. Therefore, it seems most likely that it is the fractional crystallisation of olivine, plagioclase and clinopyroxene that drives the melt to sulfur saturation, resulting in the precipitation of sulfide. Hence, the relationship between Ni (concentrated in olivine) and HSE (concentrated in sulfide) can be attributed to the coupled crystallisation of silicates and sulfide.

Sulfide may be present at relatively high proportions in MORB (up to $\sim 0.23 \%$ by mode, Kiseeva and Wood, 2015), and it strongly incorporates most HSE (section 2.3, Figure 3) with partition coefficients between $10^{4}-10^{6}$. In contrast, Re, while still being compatible compatible in sulfide, has a sulfide-silicate melt partition coefficient, at least, two orders of magnitude lower than that of the other HSE ( $\left.D_{\operatorname{Re}} \sim 10-10^{3}\right)$. Consequently, MORB sulfides have high Os (and other HSE) contents, and low Re/Os relative to their parental melt, and the effect of sulfur saturation and sulfide crystallisation will be to decrease absolute HSE abundances, and to raise the Re/Os ratio in the residual melt. 


\section{Introduction}

Mid-ocean ridge basalts form by partial melting of the Earth's upper mantle, and variations in their radiogenic isotope compositions or concentration ratios of incompatible elements are considered to reflect compositional heterogeneity in the mantle source (Tatsumoto, 1966; O'Nions et al., 1977; Kay, 1985; Hofmann, 1997). These compositional variations occur on a variety of scales and tectonic settings, ranging from the global-scale of the so-called DUPAL anomaly (centred on the Indian ocean) (Dupré \& Allègre, 1983; Hart, 1984; Hamelin \& Allègre, 1985; Hamelin et al., 1986; Michard et al., 1986; Price et al., 1986; Dosso et al., 1988; Mahoney et al., 1989, 1992; Rehkamper \& Hofmann, 1997; Escrig et al., 2004); to those associated with ocean-island volcanics or near-ridge seamounts (White \& Schilling 1978; Zindler et al., 1984; Brandl et al., 2012); to minor pervasive variations within ridge segments of normal MORB (e.g. Hofmann, 1997; Agranier et al., 2005). A number of processes have been put forward to account for these compositional variations including variable degrees of mantle depletion by prior partial melting (e.g. DePaolo \& Wasserburg, 1976; Zindler et al., 1984), the infiltration of silicate melts or fluids (e.g. Green, 1971), or recycling of lithospheric material into the mantle (e.g. Hofmann, 1997).

The ${ }^{187} \mathrm{Re}^{187}$ Os isotope system, based on the long-lived $\beta$ decay of ${ }^{187} \mathrm{Re}$ to ${ }^{187} \mathrm{Os}$, potentially provides an exceptional tracer of recycled lithosphere in Earth's mantle. This is because both oceanic and continental crust possess exceptionally high Re/Os (parent/daughter ratios), and develop radiogenic Os isotope compositions over time (e.g. Pegram \& Allègre, 1992; Shirey \& Walker, 1998; Hauri, 2002). In contrast, portions of the lithosphere have low Re/Os, and evolve to unradiogenic Os isotope compositions relative to that of the primitive upper mantle (PUM) (Walker et al., 1989; Pearson et al., 1995). These distinctive isotope signatures can be readily traced as recycled material if mixed back into the convective mantle. For example, the ${ }^{187} \mathrm{Os} /{ }^{188} \mathrm{Os}$ variations seen in HIMU ( = high $\mu=$ elevated ${ }^{238} \mathrm{U} /{ }^{206} \mathrm{~Pb}$ ) ocean island basalts indicate the presence of material that has evolved over a long-time period with high Re/Os, consistent with models indicating recycled oceanic lithosphere in the source of these volcanic rocks (Zindler and Hart, 1986; Day et al., 2010b; Day, 2013).

Some of the earliest measurements of ${ }^{187} \mathrm{Os} /{ }^{188} \mathrm{Os}$ in MORB also yielded isotope compositions more radiogenic than estimates for the primitive upper mantle (e.g. Martin, 1991; Roy-Barman and 
Allègre, 1994) and these were attributed either to contamination by seawater derived Os or melting of a heterogeneous mantle (e.g. Martin, 1991; Roy-Barman and Allègre, 1994). The work of Schiano et al (1997) on normal MORB, however, not only indicated relatively radiogenic Os isotope compositions but also that these compositions appeared to covary with the $\mathrm{Sr}-\mathrm{Nd}$ and $\mathrm{Pb}$ isotopes of the same samples. For the DUPAL anomaly, radiogenic Os isotope compositions were taken to indicate the presence of mafic continental crust in the mantle source (Escrig et al., 2004). While radiogenic ${ }^{187} \mathrm{Os} /{ }^{188} \mathrm{Os}$ isotope compositions for MORB from the south Atlantic were attributed to metasomatism of the asthenospheric mantle, and local effects from plume-ridge interaction (Escrig et al., 2005). At first sight the data from these studies might be taken to suggest that the Os isotope variations reflect those of the MORB mantle source, rather than a secondary process, and that Os isotopes do indeed act as a sensitive tracer of different recycled or enriched material in the mantle.

However, these data also indicate a covariation between the Os isotope composition and the Os elemental abundance in these samples (Schiano et al., 1997; Escrig et al., 2005). Covariations between $\mathrm{Os}, \mathrm{Ni}$ and $\mathrm{Mg}$ contents in MORB are most readily explained by fractional crystallisation (e.g. Burton et al., 2002) but in this case it is then difficult to attribute the Os isotope variations to a mantle source, leading some to propose that the radiogenic Os isotope ratios reported by these studies must result from seawater derived contamination (e.g. Shirey and Walker, 1998; Hart et al., 1999; Standish et al., 2002; Peucker-Ehrenbrink et al., 2003). Subsequent work demonstrated that many of the MORB previously analysed (Schiano et al., 1997; Escrig et al., 2004, 2005) had been affected by an analytical artefact (Gannoun et al., 2007), nevertheless a number of samples still possess relatively radiogenic isotope compositions (Gannoun et al., 2004, 2007; Yang et al., 2013, Burton et al., 2015).

Despite the potential utility of this isotope system, in particular, for tracing the presence of recycled material in MORB, these studies highlight the particular difficulties of both the measurement and the interpretation of ${ }^{187} \mathrm{Re}^{187} \mathrm{Os}$ isotope data in MORB. Mid-ocean ridge basalts possess extremely low Os concentrations, usually less than 10 parts per trillion $\left(\mathrm{pg} \mathrm{g}^{-1}\right)$ which, not only makes their accurate measurement exceptionally challenging, but also renders MORB highly susceptible to effects that are rarely seen in lithophile elements isotope systems (such as $\mathrm{Rb}-\mathrm{Sr}$ or Sm-Nd). Such effects include; (i) Radiogenic ingrowth of ${ }^{187} \mathrm{Os}$, produced from the decay of ${ }^{187} \mathrm{Re}$ over very short periods of time, (ii) seawater contamination, both direct on the sea floor or indirect in the magmatic plumbing system, and (iii) sample heterogeneity, due to variable contamination in glass or amongst coexisting magmatic phases or through sulfide nugget effects. 
Osmium has seven naturally occurring isotopes, two of which ${ }^{187}$ Os and ${ }^{186}$ Os are the decay products of long lived radioactive isotopes, ${ }^{187} \mathrm{Re}$ and ${ }^{190} \mathrm{Pt}$. Of these two decay systems, the Re-Os method has been used as a dating tool and geochemical tracer for over four decades (Shirey and Walker, 1998). Despite its great potential as a geochemical tool, analytical difficulties initially limited the application of the osmium isotope method, mainly because of the high ionization potential of Os (ca. 9eV). The discovery that a solid Os sample could yield negative molecular ions by conventional thermal ionisation (Creaser et al., 1991; Volkening et al., 1991) rendered largely obsolete all the excitation methods for atomic osmium used before (Hirt et al., 1963; Luck and Allègre, 1982; Walker and Fasset, 1986). In the N-TIMS method Os is measured as osmium trioxide $\left(\mathrm{OsO}^{3-}\right)$ via heating on platinum filaments with an electron donor. $\mathrm{A} \mathrm{Ba}-\mathrm{Na}$ emitter solution is employed to lower the work function of the filament, which enhances the emission of negative ions. The formation of the Os oxide species is also advantaged by bleeding oxygen into the source (Walczyk et al., 1991). The ionisation efficiency increases significantly with decreasing Os loads and can reach above 30\% at the pg Os level (Birck, 2001; Gannoun and Burton, 2014).

Another major problem with Re-Os isotopic analysis has been the chemical behavior of Os in solution because of the numerous oxidation states including the volatile tetraoxide species $\left(\mathrm{OsO}_{4}\right)$. At present, no single technique is equally applicable to all matrices particularly when organic matter and/or refractory mineral phases are present because the variable oxidation states may inhibit the complete homogenisation of Os between sample and spike.

High temperature $\left(\sim 250^{\circ} \mathrm{C}\right)$ oxidising digestions using either Carius tubes (Shirey and Walker, 1995) or high-pressure asher (HPA) digestion vessels (Meisel et al., 2003) have the merit of dissolving acid-resistant phases such as chromite and HSE alloys. These methods have been supplemented by employing HF digestion after Carius tube/HPA digestion (e.g., Ishikawa et al., 2014), but with mixed results (Day et al., 2015). However, such techniques can potentially yield high Os blanks (> 1pg) that can contaminate low Os ( \pm PGE and Re) abundance samples, such as MORB. Mid-ocean ridge basalt glass possesses low Os abundances, with some samples in the range of 0.2 and $3 \mathrm{pg} \mathrm{g}^{-1}$, in which refractory minerals are usually absent. For these reasons low-temperature digestion techniques have been used in preference to other approaches when analysing Os in MORB. These use HF and $\mathrm{HBr}$ in sealed Teflon vessels at temperature of $\leq 140^{\circ} \mathrm{C}$, followed by extraction of Os in liquid bromine (Birck et al., 1997). Extremely low blanks of <50 fg of Os have been achieved with this method (Gannoun et al., 2004; 2007). Furthermore, MORB glasses are likely to be completely dissolved in $\mathrm{HF}-\mathrm{HBr}$ acids mixtures even at room temperature. 
Mid-ocean ridge basalt sulfide grains can be extracted directly using a magnet and handpicked under a binocular microscope (Gannoun et al., 2004; 2007; Harvey et al., 2006) or removed from hand-polished slabs using a diamond scribe to etch around and under the grains (Warren and Shirey, 2012). The grains are weighed, spiked with ${ }^{185} \mathrm{Re}^{190} \mathrm{Os}$ and dissolved with high purity $\mathrm{HBr}$. The Os fraction is then purified using microdistillation (Birck et al., 1997; Gannoun et al., 2007, Harvey et al., 2006). It is also possible to undertake dissolution simultaneously with microdistillation (Pearson et al;, 1998). The purified Re and Os are analysed by NTIMS following the method described by Pearson et al. (1998). Osmium analysis in sulfides can also be achieved using in situ laser ablation techniques. The strength of this technique lies in the ability to relate Os isotope information from individual sulfide to their precise spatial and textural setting in the rock (Pearson et al., 2002). However single sulfide Os data analysed by the N-TIMS technique are typically of a much higher precision than in situ analysis (cf. Gannoun et al., 2007; Harvey et al., 2006; Pearson et al., 1998) even for sulfide with low Os contents (i.e. less than $10 \mu \mathrm{g} \mathrm{g}^{-1}$ ). Moreover, for in situ analysis, because of the isobaric interference of ${ }^{187} \mathrm{Re}$ on ${ }^{187} \mathrm{Os}$ accurate measurement of ${ }^{187} \mathrm{Os} /{ }^{188} \mathrm{Os}$ is only possible for sulfides with low ${ }^{187} \mathrm{Re} /{ }^{188}$ Os (Pearson et al., 2002). Such conditions are only met in the case of mantle sulfides.

\section{Rhenium-Osmium elemental variations in MORB glass.}

The fractionation of Re and Os accompanying the generation of MORB is one of the key processes controlling the distribution of these elements between Earth's mantle and crust. Osmium behaves as a highly compatible element during partial melting, and is preferentially retained in the residual mantle. Consequently, MORB have much lower concentrations, ranging from 0.18 to $170 \mathrm{pg}$ $\mathrm{g}^{-1}$ (with a mean of $10 \mathrm{pg} \mathrm{g}^{-1}$ ) than mantle peridotite, ranging from 800 to $13000 \mathrm{pg} \mathrm{g}^{-1}$ (with a mean of $3900 \mathrm{ng} \mathrm{g}^{-1}$ ). In contrast, Re is moderately incompatible during partial melting and preferentially enters the melt. Accordingly, MORB have high Re concentrations, ranging from 480 to $3000 \mathrm{pg} \mathrm{g}^{-1}$ (with a mean of $1023 \mathrm{pg} \mathrm{g}^{-1}$ ) compared to 10 to $450 \mathrm{pg} \mathrm{g}^{-1}$ in mantle peridotite (with a mean of 200 $\mathrm{pg} \mathrm{g}^{-1}$ ) (Figure 8).

By comparison, komatiiites have generally much higher Os concentrations, up to $10,000 \mathrm{pg} \mathrm{g}^{-1}$, with a similar range of Re concentrations as MORB. These high Re and Os concentrations are generally attributed to higher degrees of melting. Ocean island basalts (OIB) have Os concentrations that range from 1 to $500 \mathrm{pg} \mathrm{g}^{-1}$, and arc lavas from 0.1 to $>10 \mathrm{pg} \mathrm{g}^{-1}$. The low Os concentration of many arc lavas is likely due to extensive removal during fractional crystallization and indeed in cases where basaltic compositions have been sampled Os concentrations can be greater than $50 \mathrm{pg} \mathrm{g}^{-1}$ (Dale 
et al., 2012b). The relatively low Re concentration of many arc lavas and OIB was originally thought to reflect differences in the mineralogy of the mantle source or the extent of melting, but it is likely that for many of these samples the low Re concentrations result from volatile behaviour during subaerial eruption (e.g. Lassiter, 2003; Day et al., 2010b; Gannoun et al., 2015b). As outlined previously, the low Os concentration of MORB is likely to result, in part, from preferential partitioning into residual mantle sulfide and/or PGM phases and, in part, to the low solubility of Os in silicate melts. In addition, the Os composition of primitive MORB melts will be further reduced by sulfide segregation during fractional crystallisation. In contrast, the relatively high Re concentrations result, in part from Re being much less strongly incorporated in mantle sulfide and PGM phases and, in part, from much of the Re budget being controlled by silicate phases, and having a much higher solubility in silicate melts. Rhenium, is removed into both silicates and sulfide during fractional crystallisation.

A remarkable feature of MORB, and indeed all other terrestrial basalts, is the relatively constantly increasing fractionation of Re/Os with decreasing Os content. The values range from mantle Re/Os values of around 0.01 for Os concentrations of $2-7 \mathrm{ng} \mathrm{g}^{-1}$, to Re/Os values of $\sim 1000$ for lavas with concentrations of $0.1 \mathrm{pg} \mathrm{g}^{-1}$ (Figure 9). The systematic nature of this fractionation, suggests either that it is dominantly controlled by a single process, such as mantle melting or fractional crystallisation, or else that several process act to have the same effect, for example, fractionation by refractory mantle sulfide and also by sulfide segregation during fractional crystallisation.

Rhenium shows a broad positive covariation with $\mathrm{Al}_{2} \mathrm{O}_{3}$ and sulfur consistent with the incompatibility of all these elements during mantle melting (Figure 10). The positive $\operatorname{Re}-\mathrm{S}$ covariation might be explained by the fact that both elements will be removed into sulfide during fractional crystallization, resulting in a decreasing $\mathrm{S}$ and $\mathrm{MgO}$ content during the differentiation of $\mathrm{S}$ saturated MORB (Mathez, 1976; Bezos et al., 2005; Ballhaus et al., 2006). Despite significant scatter, Os broadly covaries with Ni in MORB (Figure 11), consistent with a role for olivine crystallisation in Os partitioning. Although previous studies have attributed the Os-Ni covariation directly to the compatibility of Os in olivine (Brügmann et al., 1987; Hart and Ravizza, 1995), natural samples and experiments indicate that Os is much less compatible. Burton et al., (2002) have shown that Os is in fact extremely incompatible in olivine. Rather it is the crystallisation of olivine that drives the melt to sulfur saturation, which in turn results in sulfide precipitation (in which Os is highly compatible) that is trapped within the olivine as 'melt inclusions' (Walker et al., 1999; Burton et al., 2002, Brenan et al., 2003, 2005). In summary, Re and Os display similar overall behaviour in MORB from the three major ocean basins. Osmium is highly compatible during melting and fractional crystallisation, whereas Re is moderately incompatible. 
The ${ }^{187} \mathrm{Os} /{ }^{188}$ Os isotope compositions for MORB from the Pacific, Atlantic and Indian Oceans are shown against the reciprocal of the concentration in Figure 12. Mid-ocean ridge basalts from the three major oceans show a similar range of ${ }^{187} \mathrm{Os} /{ }^{188} \mathrm{Os}$ isotope compositions, ranging from 0.126 to 0.148 with a mean value of $0.133 \pm 0.009$ ( $2 \sigma$ st. dev.) (Gannoun et al., 2004, 2007; Yang et al., 2013; $\mathrm{K}$ W Burton, unpublished data). There is no overall correlation with Os concentration (cf. Schiano et al., 1997; Escrig et al., 2004), however, in general MORB glasses have Os concentrations in the following order: Indian > Atlantic > Pacific, and those samples with a higher Os concentration have a tendency to possess more radiogenic ${ }^{187} \mathrm{Os} /{ }^{188} \mathrm{Os}$ compositions. Comparison of ${ }^{187} \mathrm{Os} /{ }^{188} \mathrm{Os}$ radiogenic ratios with the parent/daughter ratio, ${ }^{187} \mathrm{Re} /{ }^{188} \mathrm{Os}$, on a conventional isotope evolution diagram (Figure 13) indicates that there is no systematic covariation. The data do, nevertheless, indicate that MORB glasses with lower ${ }^{187} \mathrm{Re} /{ }^{188} \mathrm{Os}$ are generally found in the Indian > Atlantic > Pacific. In addition, those samples with the lowest ${ }^{187} \mathrm{Re} /{ }^{188}$ Os tend to possess the most radiogenic isotope compositions.

With regard to the long-lived radiogenic isotopes of $\mathrm{Sr}, \mathrm{Nd}$ and $\mathrm{Pb}$, while the cross-linked data are limited, there are no systematic variations between ${ }^{187} \mathrm{Os} /{ }^{188} \mathrm{Os}$ and ${ }^{87} \mathrm{Sr} /{ }^{86} \mathrm{Sr},{ }^{143} \mathrm{Nd} /{ }^{144} \mathrm{Nd}$, and ${ }^{206} \mathrm{~Pb} /{ }^{204} \mathrm{~Pb}$ (Figure 14). Similarly, there is no correlation between ${ }^{187} \mathrm{Os} /{ }^{188} \mathrm{Os}$ composition and ridge bathymetry or spreading rate (Figure 15) (using data compilation of DeMets et al., 2010 and Argus et al., 2011).

\section{Analytical issues associated with MORB}

Several studies have reported ${ }^{187} \mathrm{Os} /{ }^{188}$ Os data for MORB glass (Schiano et al., 1997; Escrig et al., 2004) that could not be reproduced elsewhere, using lower blank techniques (Gannoun et al., 2007; K.W. Burton unpublished data). Comparison of these data shows that for many of the relatively unradiogenic samples there is reasonably good agreement between studies (Figures 16 and 17) but notably none of the very radiogenic values previously reported were reproduced for the same samples. Such a difference might be attributed either to the nature of the samples or the methods involved in their preparation for chemistry. The earlier studies used leaching techniques to remove any Fe-Mn oxyhydroxides that may have accumulated on the glass while on the sea floor. Iron-

546 manganese precipitates, if present, are likely to possess a radiogenic Os isotope composition acquired

547 from seawater $\left({ }^{187} \mathrm{Os} /{ }^{188} \mathrm{Os}=\sim 1\right)$, therefore if present they might shift the measured ${ }^{187} \mathrm{Os} /{ }^{188} \mathrm{Os}$ to 
more radiogenic values. However, experiments on some of the same glasses indicate that extensive

549 leaching, with oxalic acid and $\mathrm{HBr}$, yields indistinguishable results to those for the same glass samples simply rinsed in dilute $\mathrm{HCl}$, ethanol and water. Another possibility is that because of the 551 large sample sizes used in the earlier studies, between 1 and 5 g (Schiano et al., 1997; Escrig et al., 2004) compared to 300 to $500 \mathrm{mg}$ (e.g. Gannoun et al., 2007), phenocrysts possessing radiogenic isotope compositions may have been inadvertently included in the material measured. Likewise, entrainment of included sulfides possessing very radiogenic compositions may have the same effect. If the radiogenic ${ }^{187} \mathrm{Os} /{ }^{188} \mathrm{Os}$ were due to the presence of entrained silicates or sulfides, then some variation in the parent/daughter ratio might be expected (cf. Figure 9 of Day 2013). Such heterogeneity is spectacularly displayed in two samples from the same locality in the Indian Ocean, where significant variations in the isotope and elemental composition of MORB glass can be attributed to the variable presence of sulfide inclusions. However, duplicate and triplicate measurement of eleven of the samples showed no resolvable variation, and there is no evidence for isotope and elemental heterogeneity in any of these glass samples. Therefore, it seems more likely that the difference in measured ${ }^{187} \mathrm{Os} /{ }^{188} \mathrm{Os}$ composition is an analytical artefact. One possibility is that this is due to interference from ${ }^{187} \mathrm{ReO}_{3}{ }^{-}$on the measured ${ }^{187} \mathrm{OsO}_{3}{ }^{-}$, although this can be carefully monitored during N-TIMS analysis through the direct measurement of ${ }^{185} \mathrm{ReO}_{3}{ }^{-}$. More likely is that the earlier data were under-corrected for the total procedural blank during chemical purification. The blanks of the original studies possessed a radiogenic ${ }^{187} \mathrm{Os} /{ }^{188} \mathrm{Os}$ composition, and the difference between the earlier data (Schiano et al., 1997; Escrig et al., 2004) and those samples that were reanalysed increases with decreasing Os concentration in the sample, consistent with increasing contribution from the blank (Figure 17). Overall, these studies highlight the analytical difficulties of obtaining accurate ${ }^{187} \mathrm{Os} /{ }^{188} \mathrm{Os}$ data for MORB glass many of which possess low Os concentrations (i.e. between 0.2 and $5 \mathrm{pg} \mathrm{g}^{-1}$ ).

\section{The origin of the Os isotope variations in MORB glass}

Notwithstanding any shifts that arise from analytical problems, the data obtained thus far, for 577 all the major oceans, indicates a resolvable variation in the ${ }^{187} \mathrm{Os} /{ }^{188} \mathrm{Os}$ isotope composition of MORB, ranging from values similar to those expected for the primitive upper mantle (e.g. Meisel et al., 1996) to radiogenic compositions akin to those found in ocean island basalts (e.g. Day, 2013). It

580 is unlikely that these data have also been compromised by analytical problems; first, because there is 581 no covariation between the corrected ${ }^{187} \mathrm{Os} /{ }^{188} \mathrm{Os}$ and the Os concentration, as might be expected if 
582 the blank concentration was not correctly determined. Second, replicates with differing sample 583 weights and subject to different dissolution technique yield indistinguishable ${ }^{187} \mathrm{Os} /{ }^{188} \mathrm{Os}$ values 584 (Gannoun et al., 2007; Yang et al., 2013, Burton et al., 2015). Moreover, those samples with radiogenic ${ }^{187} \mathrm{Os} /{ }^{188} \mathrm{Os}$ compositions are actually those with the highest Os concentrations, and therefore would be less susceptible to any blank effect. Finally there is no significant covariation between $\mathrm{Os}$ and $\mathrm{Sr}, \mathrm{Nd}$ or $\mathrm{Pb}$ isotopes, as might be expected if the variations were due to compositional heterogeneity in the mantle source.

Radiogenic growth of ${ }^{187}$ Os since MORB eruption. For lithophile elements, such as $\mathrm{Sr}$ or $\mathrm{Nd}$, parent/daughter ratios in MORB glass and coexisting silicates are relatively low, consequently shifts in their radiogenic isotope composition are unlikely to have a measurable effect for timescales less than $10^{3}$ million years (e.g. Hofmann, 1997). Therefore variations in $\mathrm{Sr}$ or $\mathrm{Nd}$ isotope composition preserved in MORB can be attributed to compositional heterogeneity in the upper mantle source (e.g. Hofmann, 1997). For the ${ }^{187} \operatorname{Re}_{-}{ }^{187}$ Os system however, silicate phases and glass possess exceptionally high ${ }^{187} \mathrm{Re} /{ }^{188} \mathrm{Os}$ (parent/daughter). This then raises the possibility that radiogenic ${ }^{187} \mathrm{Os}$ could be produced in situ from the decay of ${ }^{187} \mathrm{Re}$ over relatively short periods of time (that is a few hundred thousand years or less; e.g. Hauri et al., 2002, Gannoun et al., 2004, 2007). For example, MORB glass possesses ${ }^{187} \mathrm{Re} /{ }^{188}$ Os with values ranging from 30 to 8000 (Gannoun et al., 2007; Yang et al., 2013), and a glass with ${ }^{187} \mathrm{Re} /{ }^{188} \mathrm{Os}=4000$ would produce a shift in ${ }^{187} \mathrm{Os} /{ }^{188} \mathrm{Os}$ from mantle values of 0.1296 to a value of 0.14 in less than 250 thousand years (Gannoun et al., 2007). This effect is illustrated in Figure 13, where timescales of between $50 \mathrm{ka}$ and $>1$ Ma could produce the range of ${ }^{187} \mathrm{Os} /{ }^{188} \mathrm{Os}$ preserved in the MORB glasses if they were simply due to the decay of Re.

One approach to determining the age of crystallisation of the MORB glasses is the measurement of short-lived isotopes of Th-U and Ra in the same samples. Such Th-U-Ra data were obtained for a few MORB glasses spanning much of the observed range of ${ }^{187} \mathrm{Os} /{ }^{188} \mathrm{Os}$ compositions for the datasets in Gannoun et al. (2004, 2007). Of those samples measured, if it is assumed that they initially possessed a PUM-like composition at the time of crystallization, then between $700 \mathrm{kyr}$ and 1.25 Myr would be required to generate their given ${ }^{187} \mathrm{Os} /{ }^{188} \mathrm{Os}$ isotope compositions. However, the same samples possess ${ }^{230} \mathrm{Th} /{ }^{232} \mathrm{Th}$ activity ratios greater than 1 , suggesting that they must be $\leq 350$

611 kyr old (that is, the maximum time available before all ${ }^{230} \mathrm{Th}$ has decayed). Moreover, all but one sample has a ${ }^{226} \mathrm{Ra} /{ }^{230} \mathrm{Th}$ activity ratio that is also greater than 1 , suggesting those samples must be $\leq$ $6138 \mathrm{kyr}$ old. Therefore, for these samples, at least, the radiogenic ${ }^{187} \mathrm{Os} /{ }^{188} \mathrm{Os}$ compositions cannot be 614 explained solely as a result of in situ decay of ${ }^{187}$ Re subsequent to igneous crystallisation (Gannoun et al., 2004, 2007). 
An alternative approach that can be used with phenocryst-bearing MORB samples is to obtain

618 Re-Os isotope data for the constituent phases in MORB, including sulfide, glass, spinel, olivine, 619 clinopyroxene and spinel (Gannoun et al., 2004). If these coexisting phases are in Os isotope 620 equilibrium, then they may yield an isochron that will give the age of crystallisation, and the initial 621 Os isotope composition defined by the best-fit line will correspond to that of the mantle source. 622 However, if some of the phases were assimilated from previously crystallised basalts, gabbro (from 623 deeper in the oceanic crust), or contaminated by seawater, then they may possess different isotope 624 information to that of the host glass or other minerals (Gannoun et al., 2004). ${ }^{187} \mathrm{Re}^{187}$ Os data were 625 obtained for coexisting phases from two MORB samples from the FAMOUS region on the mid626 Atlantic ridge (Figures 18 and 19). These results illustrate the age information that can be obtained 627 from MORB glass and coexisting phases, some of the processes involved in MORB genesis, and the $628{ }^{187} \mathrm{Os} /{ }^{188}$ Os composition of the MORB source. Sample ARP1974-011-018 $\left(36.85^{\circ} \mathrm{N} ; 33.25^{\circ} \mathrm{W}\right)$ is an 629 olivine basalt containing olivine (Fo90-Fo80), plagioclase (An91-An95), and clinopyroxene $630\left(\mathrm{Wo}_{44} \mathrm{En}_{15} \mathrm{Fs}_{5}-\mathrm{Wo}_{40} \mathrm{En}_{15} \mathrm{Fss}_{9}\right)$ phenocrysts (up to 1 to $2 \mathrm{~mm}$ in diameter) and microphenocrysts in a 631 hyalocrystalline matrix, and, in places, a glassy pillow rim (e.g. Le Roex et al., 1981). The ${ }^{187} \operatorname{Re}^{-}$ $632{ }^{187}$ Os isotope data for matrix, glass, plagioclase, and olivine yield a best-fit line corresponding to an 633 age of $565 \pm 336 \mathrm{ky}$ and an initial ${ }^{187} \mathrm{Os} /{ }^{188} \mathrm{Os}$ ratio of $0.1265 \pm 0.0046$ (Figure 18). The data for 634 clinopyroxene are distinct from this best-fit line, suggesting either an older age or a different and 635 more radiogenic source for this phase. Sample ARP1973-010-003 (36.8372 ${ }^{\circ}$; $33.2482^{\circ} \mathrm{W} ; 2760-\mathrm{m}$ water depth) is a porphyritic, picritic basalt with abundant olivine phenocrysts (Fo91-Fo89; up to 5 $\mathrm{mm}$ in diameter) set in a glassy to hyalocrystalline matrix. $\mathrm{Cr}$-spinel $[\mathrm{Cr} /(\mathrm{Cr}+\mathrm{Al})=48.01]$ phenocrysts and sulfide [ 14 weight percent (wt \%) Ni] blebs (up to $1 \mathrm{~mm}$ in diameter) occur as inclusions in olivine or discrete crystals in the groundmass. Plagioclase $\left(\mathrm{An}_{80}\right)$ microlites are also common (Le Roex et al., 1981, Su and Langmuir, 2003). The ${ }^{187} \mathrm{Re}^{187} \mathrm{Os}$ data for olivine, plagioclase, glass, and sulfide yield a best-fit line corresponding to an age of $2.53 \pm 0.15 \mathrm{My}$ and an initial ${ }^{187} \mathrm{Os} /{ }^{188} \mathrm{Os}$ ratio of $0.129 \pm 0.002$ (Figure 19). Spinel, which is relatively Os-rich (Table 1 of Gannoun et al., 2004), possesses a distinct isotope composition from this best-fit line and is probably the phase responsible for the displacement of the matrix from the same line.

The simplest interpretation of these data is that the ages represent the time of igneous crystallization and the initial Os isotope composition represents that of the mantle source. The crystallization ages are, however, much older than might be expected from age-distance relations with the ridge axis that suggest ages of 5 to $10 \mathrm{kyr}$ (Selo and Storzer, 1979). They are also different to the ages inferred from the Th-U-Ra isotope composition of the glass. Glass from sample 
ARP1974-011-018 gives a ${ }^{226} \mathrm{Ra} /{ }^{230} \mathrm{Th}$ activity ratio close to 1 , suggesting that the sample is $\leq 8 \mathrm{ky}$

651

652

653

654

655

656

657

658

659

660

661

662

663

664

665

666

667

668

669

670

671

672

673

674

675

676

677

678

679

680

681

682 old, whereas the ${ }^{230} \mathrm{Th} /{ }^{232} \mathrm{Th}$ activity ratio is 1.273 , suggesting that the sample is $\leq 350$ ky old, consistent with previous ${ }^{230} \mathrm{Th}$ data for the same sample (Condomines et al., 1981). Arguably the ${ }^{187} \mathrm{Re}^{187} \mathrm{Os}$ age of $565 \pm 336 \mathrm{kyr}$ is indistinguishable from the ${ }^{230} \mathrm{Th}$ age constraints. Glass from sample ARP1973-010-003 gives ${ }^{226} \mathrm{Ra} /{ }^{230} \mathrm{Th}$ ratio of 1.3 , which might at first be taken to indicate that the sample is less than $8 \mathrm{ky}$ old. However, the same sample has a ${ }^{234} \mathrm{U} /{ }^{238} \mathrm{U}$ ratio of 1.043 , and such elevated values are often taken to indicate seawater contamination, consistent with previously published data for this sample (Condomines et al., 1981), which raises the possibility that Ra has also been affected by the same seawater contamination. It might be argued that the best-fit lines are due to contamination by radiogenic Os from seawater, rather than having some age significance. This would require that the contamination occurred during mineral crystallization and has affected phases such as olivine and plagioclase in a systematic manner; otherwise, it is difficult to imagine how different phases would align to yield the correlations observed.

Alternatively, the data may indicate that few if any of the constituent phases crystallized in their present basalt host (i.e., they are xenocrysts not phenocrysts). There is evidence for assimilation of xenocrystic phases in samples from the FAMOUS region (e.g. Clocchiati, 1977; le Roex et al., 1981; Shimizu, 1998). For example, in this sample high-Al spinel is considered to be a relict from high-pressure crystallization (Sigurdsson and Schilling, 1976), which suggests that spinel is not in Os isotopic equilibrium with the other phases. However, if most of the phases lie on the same best-fit line, then this interpretation demands that all such minerals are xenocrysts. For the picritic basalt, if eruption occurred about 5 to $10 \mathrm{kyr}$ ago, then the $\mathrm{Re}-\mathrm{Os}$ isotopic data indicate that original crystallization of the minerals occurred about 2.5 Myr prior to this event. In this case, the xenocrysts were assimilated from previously solidified "olivine-plagioclase" basalts, or cumulates through which the present host basalts have ascended.

Taken together, these results demonstrate that the radiogenic ${ }^{187} \mathrm{Os} /{ }^{188} \mathrm{Os}$ composition of MORB glass can be readily generated from the decay of ${ }^{187} \mathrm{Re}$ over very short timescales (that is, a few hundred thousand years or less). Nevertheless, the ages obtained for the samples from the FAMOUS region on the mid-Atlantic ridge are much older than might be expected on the basis of their distance from the ridge axis, and this can only be explained either by seawater contamination (that occurred during the crystallisation of magmatic minerals) or by the entrainment of crystals (i.e. xenocrysts) from older oceanic crust. 
Extreme ${ }^{187} \mathrm{Os} /{ }^{188}$ Os heterogeneity in MORB glass. Occasionally MORB itself shows significant Os isotope and elemental heterogeneity. For example, replicate measurements of the MORB sample EN026 10D-3 show significant heterogeneity, with ${ }^{187}$ Os $/{ }^{188}$ Os isotope compositions that range from 0.128 to $>0.15$ (Day et al., 2010b). For MORB glass this is exemplified by two samples from the same locality on the central Indian ridge, MD57 D9-1 and D9-6 $\left(8.01^{\circ} \mathrm{S} ; 68.07^{\circ} \mathrm{E}\right)$ which show ${ }^{187} \mathrm{Os} /{ }^{188} \mathrm{Os}$ compositions ranging from 0.126 to 0.254 , with covariations in Os concentration (Figure 20). Those samples with the least radiogenic ${ }^{187} \mathrm{Os} /{ }^{188} \mathrm{Os}$ composition possess unusually high Os concentrations ( $\mathrm{up}$ to $220 \mathrm{pg} \mathrm{g}^{-1}$ ). Sulfides from the same samples possess ${ }^{187} \mathrm{Os} /{ }^{188} \mathrm{Os}$ between 0.126 to 0.132 , and concentrations between 136 and $246 \mathrm{ng} \mathrm{g}{ }^{-1}$. Given the presence of Os-rich sulfides in these samples, it seems most likely that this heterogeneity is due to the entrainment of this phase. If the radiogenic ${ }^{187} \mathrm{Os} /{ }^{188} \mathrm{Os}$ isotope composition of the glass is simply due to the radiogenic growth of ${ }^{187} \mathrm{Os}$ from the decay of ${ }^{187} \mathrm{Re}$, since the time of igneous crystallization, then the initial ratio determined from elemental or parent/daughter ratios may reflect the composition of the source (cf. Day, 2013). Alternatively, if the radiogenic composition of the glass is due to seawater contamination or altered oceanic crust then the initial ${ }^{187} \mathrm{Os} /{ }^{188} \mathrm{Os}$ isotope composition determined from such covariations may have little relationship with that of the mantle source.

Seawater contamination or assimilation of altered oceanic crust. The age constraints from spreading rates, Th-U-Ra disequilibria and ${ }^{187} \mathrm{Re}-{ }^{187}$ Os isotope data for MORB glass and coexisting minerals suggest that the radiogenic ${ }^{187} \mathrm{Os} /{ }^{188} \mathrm{Os}$ isotope compositions of MORB glass cannot be solely explained by an age effect following igneous crystallisation. An alternative possibility is that these radiogenic compositions could be due to seawater contamination, either occurring directly during quenching of the glass on the ocean floor or through the assimilation of hydrothermally altered oceanic crust in the magmatic plumbing system. Seawater possesses a very radiogenic ${ }^{187} \mathrm{Os} /{ }^{188}$ Os composition ( 1.026-1.046) (e.g. Sharma et al., 2012, Gannoun and Burton, 2014) and a ${ }^{187} \mathrm{Re} /{ }^{188} \mathrm{Os}$ ratio of $\sim 3400$, (calculated using the Os concentrations from Sharma et al., 2012, Gannoun and Burton, 2014 and Re from Anbar et al., 1992, Colodner et al., 1993). In this case, seawater contamination could account for both the radiogenic Os isotope composition and the tendency of such samples to possess relatively low ${ }^{187} \mathrm{Re} /{ }^{188} \mathrm{Os}$.

Trace elements that are enriched in seawater, such as $\mathrm{Cl}$ or B could potentially be used as indicators of seawater contamination. At first sight, however, there is no apparent covariation of 714 either $\mathrm{B}$ or $\mathrm{Cl}$ with ${ }^{187} \mathrm{Os} /{ }^{188} \mathrm{Os}$ in the MORB glasses. Rather the variations that do exist indicate that many of the samples with radiogenic Os compositions possess low $\mathrm{Cl}$ and $\mathrm{B}$ concentrations, 716 inconsistent with seawater contamination (Figure 21). The difficulty in interpreting $\mathrm{Cl}$ and $\mathrm{B}$ is that 
717 both are highly incompatible elements, and therefore they are strongly affected by partial melting and 718 fractional crystallisation (Michael and Schilling, 1989; Chaussidon and Jambon, 1994; Jambon et al., 719 1995; Michael and Cornell, 1998). Indeed, Cl and B for the same MORB glasses show a negative covariation with $\mathrm{MgO}$ suggesting that fractional crystallisation has strongly influenced their abundances, thereby masking any subtle effects from seawater contamination. Like $\mathrm{Cl}$ and $\mathrm{B}, \mathrm{K}$ also behaves as a highly incompatible element during melting and crystallisation, in this case an alternative approach is to use incompatible element ratios such as $\mathrm{B} / \mathrm{K}$ or $\mathrm{Cl} / \mathrm{K}$ that are not significantly fractionated during crystallisation to place some constraints on potential contamination by seawater. For example, mantle $\mathrm{Cl} / \mathrm{K}$ ratios are lower than 0.08 , whereas altered oceanic crust has a $\mathrm{Cl} / \mathrm{K}$ ratio $\sim 0.1$, and seawater $\sim 50$ (Michael and Schilling, 1989; Jambon et al., 1995; Michael and Cornell, 1998). However, again there is no clear co-variation of $\mathrm{Cl} / \mathrm{K}$ with ${ }^{187} \mathrm{Os} /{ }^{188} \mathrm{Os}$, rather the radiogenic Os values appear to possess low $\mathrm{Cl} / \mathrm{K}$ (Gannoun et al., 2007).

A more robust tracer of seawater interaction is provided by ${ }^{11} \mathrm{~B} /{ }^{10} \mathrm{~B}$ of the MORB glasses. The upper mantle is thought to possess a $\delta^{11} \mathrm{~B}$ value (Chaussidon and Marty, 1995) of - $10 \%$, (where $\delta^{11} \mathrm{~B}$ $=1000 \times\left[\left({ }^{11} \mathrm{~B} /{ }^{10} \mathrm{~B}_{\text {sample }} /{ }^{11} \mathrm{~B} /{ }^{10} \mathrm{~B}_{\text {standard }}\right)-1\right]$ relative to the borate standard NBS 951 with an ${ }^{11} \mathrm{~B} /{ }^{10} \mathrm{~B}$ ratio of 4.04558). In contrast, for altered oceanic crust $\delta^{11} \mathrm{~B}$ ranges from +2 to $+9 \%$, seawater has a $\delta^{11} \mathrm{~B}=+39.5 \%$ (e.g., Spivak and Edmond, 1987; Smith et al., 1995) and serpentinized oceanic mantle samples can range from $+9 \%$ to $+39 \%$ (Boschi et al., 2008; Vils et al., 2009; Harvey et al., 2014a). While melting and crystallisation processes are unable to significantly fractionate boron isotopes, mixing with altered oceanic crust and mantle can account for the $\delta^{11} \mathrm{~B}$ range of -7 to $-1 \%$ o observed in MORB (Chaussidon and Jambon, 1994).

The $\delta^{11} \mathrm{~B}$ values of MORB glasses for which ${ }^{187} \mathrm{Os} /{ }^{188} \mathrm{Os}$ data are available range from -9 to $+2 \%$, and those samples with high $\delta^{11} \mathrm{~B}$ values also possess radiogenic ${ }^{187} \mathrm{Os} /{ }^{188} \mathrm{Os}$ compositions (Figure 22). The B concentration of seawater is $\sim 4.6 \mu \mathrm{g} \mathrm{g}^{-1}$ which is some 5-10 times higher than that of unaltered MORB $\left(<1 \mu \mathrm{g} \mathrm{g}^{-1}\right)$, whereas the Os concentration in seawater of $10^{-2} \mathrm{pg} \mathrm{g}^{-1}$ is some

7423 orders of magnitude less than that of average MORB. Direct mixing of seawater would be 743 dominated by B at the low mixing proportions suggested in Figure 22 (that is, a horizontal vector in 744 Os versus $\delta^{11} \mathrm{~B}$ ) indicating that the radiogenic ${ }^{187} \mathrm{Os} /{ }^{188} \mathrm{Os}$ and high $\delta^{11} \mathrm{~B}$ values cannot be easily explained by direct contamination from seawater. Conversely, contamination from Fe-Mn crust with a seawater Os isotope composition would produce far greater shifts in ${ }^{187} \mathrm{Os} /{ }^{188} \mathrm{Os}$ than $\mathrm{B}$. Rather, the co-variations are entirely consistent with the assimilation of between $5-10 \%$ of altered oceanic crust with a variable ${ }^{187} \mathrm{Os} /{ }^{188} \mathrm{Os}$ composition.

It might be argued that the relatively heavy $\delta^{11} \mathrm{~B}$ values $(>-5 \%)$, and the radiogenic ${ }^{187} \mathrm{Os} /{ }^{188} \mathrm{Os}$ could be due to the presence of recycled oceanic crust (present as pyroxenite) in the 
MORB mantle source. Recycled oceanic crust can lose substantial amounts of Re during subduction ( $\sim 50 \%$ or more, Becker, 2000; Dale et al., 2007) but Re/Os ratios are still sufficiently elevated to produce radiogenic ${ }^{187} \mathrm{Os} /{ }^{188} \mathrm{Os}$ values with time. However, recent studies suggest that during dehydration of the subducting slab, B is preferentially partitioned into the released fluids, leaving a depleted residue (Moran et al., 1992; Bebout et al., 1993; Peacock and Hervig, 1999; Nakano and Nakamura, 2001; Harvey et al., 2014b). Furthermore, boron isotope fractionation occurs during such dehydration and the residue becomes increasingly enriched in the light $\mathrm{B}$ isotope $\left({ }^{10} \mathrm{~B}\right)$ generating light $\delta^{11}$ B values (You et al., 1996; Ishikawa et al., 2001; Leeman et al., 2004), rather than the heavy values required to generate the ranges observed in MORB.

Notwithstanding analytical difficulties, the Os isotope and elemental variations in MORB glass, the mismatch in age constraints and measured ${ }^{187} \mathrm{Os} /{ }^{188} \mathrm{Os}$ compositions, and the covariations with $\mathrm{B}$ isotopes suggest that assimilation of seawater-altered oceanic crust is likely to be the dominant process responsible for the radiogenic Os isotope signal seen in many of the MORB glasses studied thus far.

\section{Petrology and chemistry}

Sulfide is a ubiquitous phase in MORB glass, indicating that these melts were sulfur saturated (Wallace and Carmichael, 1992). Because decompression will drive the melt away from sulfide saturation (e.g. Mavrogenes and O’Neill, 1999) it might be expected that most MORB would be undersaturated when transported to lower pressures during eruption. The presence of sulfide globules in early crystallising phases, however, clearly indicates that MORB are sulfur saturated during the initial stages of magmatic evolution (Mathez and Yeats, 1976; Patten et al., 2012; Yang et al., 2014) and, as previously suggested for MORB, this sulfur saturation is most likely to result from fractional crystallisation itself. In addition, MORB contain more sulfur than subaerially erupted basalt, because degassing is impaired by the overlying pressure of seawater.

Sulfides occur as spherules embedded in the walls of large vesicules (Moore and Calk, 1971; Moore and Schilling, 1973), as small irregular grains in microcrystalline aggregates of plagioclase and olivine (Mathez and Yeats, 1976) and as well-developed spherical globules, in glass or in phenocrysts (Mathez and Yeats, 1976; Czamanske and Moore, 1977; Patten et al., 2012; Roy-Barman et al., 1998) (Figures 23a and 23b). The globules, which range from 5 to $600 \mu \mathrm{m}$ in diameter, have 
different textures that can be divided into three groups (Moore and Calk, 1971; Mathez, 1976;

785 Mathez and Yeats, 1976; Czamanske and Moore, 1977; Peach et al., 1990; Roy-Barman et al., 1998; Patten et al., 2012; 2013). The first, comprise a fine grained micrometric intergrowth of Fe-Ni-rich and $\mathrm{Cu}-\mathrm{Fe}$-rich sulfide phases that represent quenched monosulfide solid solution (MSS) and intermediate solid solution (ISS). The second, comprise globules of coarser grained intergrowth of MSS and ISS with pentlandite and oxide (Mathez, 1976; Czamanske and Moore, 1977; Patten et al., 2012) and the third group comprise zoned globules that consist of two massive and distinct grains of MSS and ISS, first identified recently by Patten et al. (2012).

Pentlandite and oxide occur to a lesser extent in all types of textures. Sulfide droplets with different sizes and textures may coexist in the same MORB sample. Patten et al. (2012) have shown that sulfide droplets exhibiting all three textures may be present in the same sample separated by only few millimetres, (cf. Czamanske and Moore, 1977). Patten et al. (2012) also observed a relationship between the size of the droplets and their textures. Below $30 \mu \mathrm{m}$, over $90 \%$ of the droplets have a fine grained texture and between 30 and $50 \mu \mathrm{m}, 60 \%$ of the sulfide droplets are coarse-grained. In contrast, above $50 \mu \mathrm{m}$ all the droplets are zoned.

Sulfide globules usually comprise fine-grained exsolution of $\mathrm{Fe}-\mathrm{Ni}$ and $\mathrm{Cu}$-rich sulfide phases. When the bulk compositions of sulfide are calculated to $100 \%$, in order to estimate liquidus temperature of the MSS using the Ebel and Naldrett (1997) approach for O-free systems, they showed low variability in $\mathrm{S}$ content, moderate variability in Fe contents and high variability in $\mathrm{Cu}$ and Ni contents (Patten et al., 2012). Figure 24 shows the bulk composition of sulfide globules in the $\mathrm{Fe}-\mathrm{Ni}-\mathrm{Cu}$ system. The limited field of such bulk compositions confirms the agreement between different studies (Czamanske and Moore, 1977; Roy-Barman et al., 1998; Patten et al., 2012). The dashed lines in Figure $\mathbf{2 4}$ indicate the sulfide liquid at crystallisation temperatures of the MSS at 1100,1050 and $1000^{\circ} \mathrm{C}$ from Ebel and Naldrett (1997). The liquidus temperature of the sulfide globules from MORB determined in this way, range from slightly above $1100^{\circ} \mathrm{C}$ to $1030^{\circ} \mathrm{C}$ where globules are randomly distributed over this temperature interval irrespective of their size or textures (cf. Patten et al., 2012).

Pentlandite occurs to a lesser extent than MSS and ISS in all textures of sulfides. Oxide also occurs either inside MSS, inside ISS or at their interface, comprising up to $7 \%$ of some sulfide globules. Oxides are best developed in zoned droplets and electron probe analyses reveal that they are Ti-free magnetite (Patten et al., 2012) in agreement with Czamanske and Moore (1977), who 
If present, sulfide dominates the Os budget in MORB, where sulfide-silicate partition coefficients for Os in basaltic system are in the range $\sim 10^{4}-10^{6}$ (Roy-Barman et al., 1998; Gannoun et al., 2004, 2007). In contrast, Re while still being highly compatible in sulfide, has a partition coefficient at least two orders of magnitude lower than that of Os $\left(\sim 10^{1}-10^{3}\right.$; Roy-Barman et al., 1998; Gannoun et al., 2004, 2007) similar to that of $\mathrm{Cu}$ (Peach et al., 1990; Gaetani and Grove, 1997). As a result of the difference in partitioning of Re and Os, MORB sulfides have high Os concentrations (tens to a few hundreds of $\mathrm{ng} \mathrm{g}^{-1}$ ) and a low Re/Os relative to their coexisting glass (some 3 orders of magnitude lower). Consequently, sulfide is much less susceptible to the effects of seawater assimilation, or radiogenic in-growth, than coexisting silicate minerals or glass (RoyBarman et al., 1998; Gannoun et al., 2004, 2007).

For those sulfides for which Os isotope and elemental abundances have been measured thus far, there is a clear covariation between ${ }^{187} \mathrm{Os} /{ }^{188} \mathrm{Os}$ and the Os concentration (Figure 25). Where those sulfides with low Os concentrations (i.e $\leq 10 \mathrm{ng} \mathrm{g}^{-1}$ ) possess ${ }^{187} \mathrm{Os} /{ }^{188}$ Os compositions $>0.15$, and those with high Os concentrations (i.e. $\geq 100 \mathrm{ng} \mathrm{g}^{-1}$ ) possess ${ }^{187} \mathrm{Os} /{ }^{188} \mathrm{Os}$ compositions around $\sim 0.13$ or less. At first sight, this relationship might be taken to indicate that the sulfide globules, like their host glass have been systematically affected by contamination with material derived from altered oceanic crust. There is no clear relationship between the Os concentration of the sulfide and that of the host glass. However, with one exception, sulfides possess ${ }^{187} \mathrm{Os} /{ }^{188} \mathrm{Os}$ values that are less radiogenic than their glass host, where in general, the more radiogenic the host glass the greater the difference in ${ }^{187} \mathrm{Os} /{ }^{188} \mathrm{Os}$ with coexisting sulfide (Figure 26). It is difficult to explain such a difference between sulfide and glass simply by radiogenic decay of ${ }^{187} \mathrm{Re}$, rather it suggests that the ${ }^{187} \mathrm{Os} /{ }^{188} \mathrm{Os}$ composition of the glass has been more significantly affected by the assimilation of older oceanic crustal material than the coexisting sulfide.

If MORB sulfides preserve ${ }^{187} \mathrm{Os} /{ }^{188} \mathrm{Os}$ compositions that are systematically less radiogenic than their host silicate glass then this has some important implications for the timing of contamination relative to crystallisation. If contamination of the silicate melt occurred before sulfide precipitation then the sulfide should possess an Os isotope composition that is indistinguishable from that of the melt. Therefore, the contrasting Os isotope composition of the glass and sulfide suggests that the silicate melt experienced contamination after the segregation of sulfide in the melt.

At the high temperatures of MORB eruption $\left(\sim 1200^{\circ} \mathrm{C}\right)$ most sulfides will be present as liquid globules rather than as a solid phase, and diffusional equilibration between silicate and sulfide liquids is likely to be rapid. The time in which a sulfide globule will equilibrate its Os isotope composition 
with a melt can be assessed using simple diffusion calculations. Using an implicit finite difference model (Crank, 1975) and assuming a sulfide globule radius of $250 \mu \mathrm{m}$ and a silicate-sulfide melt diffusion coefficient of $10^{-8} \mathrm{~cm}^{2} \mathrm{~s}^{-1}$ the sulfide will equilibrate with the melt in $\sim 12 \mathrm{~h}$ (Gannoun et al., 2007). This is a relatively conservative estimate because cation diffusion in most basaltic melts is $10^{-5}$ to $10^{-6} \mathrm{~cm}^{2} \mathrm{~s}^{-1}$ (Watson and Baker, 1975), whereas diffusion rates in pyrrhotite are likely to be faster than $10^{-9} \mathrm{~cm}^{2} \mathrm{~s}^{-1}$ at magmatic temperatures (Brenan et al., 2000). Therefore, under normal circumstances, complete equilibration between sulfide and glass would be expected, with both possessing an indistinguishable ${ }^{187} \mathrm{Os} /{ }^{188} \mathrm{Os}$ composition. However, because of the large concentration difference between the sulfide and the silicate liquid, a large amount of melt has to exchange with a small sulfide bleb before the sulfide reaches Os isotope equilibrium with the glass. It is possible to calculate the volume (and mass) of melt that is needed to equilibrate the sulfide using simple mass balance equations and the concentration and isotopic data for the glass and sulfides obtained here. Assuming initial ${ }^{187} \mathrm{Os} /{ }^{188} \mathrm{Os}$ for the sulfides of 0.125 and a sulfide globule radius of $250 \mu \mathrm{m}$, then sulfides will have only equilibrated with $<0.5 \mathrm{~cm}^{3}$ of melt (or less if the sulfide blebs were smaller). This suggests that the sulfides have only exchanged with the immediate melt surrounding the sulfide. Furthermore, a sulfide that contains $>200 \mathrm{ng} \mathrm{g}^{-1}$ Os would have to exchange with $<50 \mathrm{~cm}^{3}$ of melt in order to completely equilibrate with that melt. Thus, the absence of any Os isotope or elemental covariation between the sulfides and their host glass suggests that Os isotope exchange is likely to have been limited. These observations are consistent with Pd elemental data for MORB from the SouthWest Indian Ridge taken to suggest that segregated sulfides were poorly equilibrated with their host silicate magmas (Yang et al., 2013).

Nevertheless, many, if not all of the sulfides analysed thus far are likely to have been modified by contamination, depending on their Os concentration. The sulfides with ${ }^{187} \mathrm{Os} /{ }^{188}$ Os compositions $>0.13$ have most likely been significantly modified through partial exchange with the contaminated silicate melt. Although those sulfides with a high Os concentration $\left(>20 \mathrm{ng} \mathrm{g}^{-1}\right)$ may have also been affected by such exchange they do, however, yield the least radiogenic compositions yet observed in normal MORB samples.

\section{The ${ }^{187} \mathrm{Os} /{ }^{188} \mathrm{Os}$ isotope composition of the MORB mantle source}

The MORB glass measured thus far preserves variations in ${ }^{187} \mathrm{Os} /{ }^{188}$ Os extending from unradiogenic values as low as 0.125 , comparable to estimates for the primitive upper mantle, to radiogenic values up to 0.25 . There are no clear covariations with lithophile element isotopes, such as $\mathrm{Sr}$ or $\mathrm{Nd}$, as might be expected from Os isotopic heterogeneity inherited for a mantle source. Rather, 
the radiogenic Os isotope compositions show a relationship with B isotopes that is most simply attributed to seawater-derived contamination that occurs during magma ascent. In this case, to a greater or lesser extent all MORB glass has been affected by seawater contamination. Individual sulfide grains appear to provide a much more robust record of the primary Os isotope signature (RoyBarman et al., 1998; Gannoun et al., 2004; 2007, Burton et al., 2015) although even this phase appears to be susceptible to seawater-derived contamination. In this case it is difficult to assess the extent to which any radiogenic signal, preserved in either glass or sulfide, is due to an age effect caused by ${ }^{187} \mathrm{Re}$ decay following igneous crystallisation, or the presence of Re-enriched material, such as recycled oceanic crust in the MORB source.

Assuming that the Os isotope information preserved by high-Os sulfide grains has been minimally affected by seawater contamination then they potentially provide some unique constraints on the nature of the MORB source. A fundamental assumption underlying the use of radiogenic isotopes, such as $\mathrm{Sr}, \mathrm{Nd}$ and $\mathrm{Os}$, in mantle derived basalts is that they are in equilibrium with their mantle source (e.g., Hofmann and Hart, 1978). Abyssal peridotites are ultramafic rocks thought to represent the residue of the melting responsible for generating MORB (Dick et al., 1984; Johnson and Dick, 1992; Brenan et al., 2000). Consequently during melting and basalt genesis the composition of long-lived isotopes of heavy elements in both MORB and residual abyssal peridotites should be the same. The average ${ }^{187} \mathrm{Os} /{ }^{188}$ Os composition of abyssal peridotites is $0.127 \pm 0.015(\mathrm{n}=129)$ (Figure 27), however, like MORB, abyssal peridotites are also susceptible to seawater alteration during their exhumation on the sea floor, which may shift the composition towards radiogenic values. In this case individual abyssal peridotite sulfides are likely to yield a more reliable indication of their primary Os isotope composition, and these yield an average ${ }^{187} \mathrm{Os} /{ }^{188} \mathrm{Os}$ composition of $0.125 \pm 0.021(\mathrm{n}=63)$. The best estimate for the ${ }^{187} \mathrm{Os} /{ }^{188} \mathrm{Os}$ composition of the primitive upper mantle, that is a theoretical mantle composition with high $\mathrm{Al}_{2} \mathrm{O}_{3}$ that is considered to have experienced no depletion through melting, is $0.1296 \pm 0.009(2 \sigma ; \mathrm{n}=117)$ (Meisel et al., 2001). By comparison, the high-Os $\left(>20 \mathrm{ng} \mathrm{g}^{-1}\right)$ 911 sulfides from MORB yield an average composition of $0.129 \pm 0.005(\mathrm{n}=31)$ with values as low as 9120.1236 (Figure 27). Therefore, these high-Os sulfides show no evidence for significant Re 913 enrichment in the MORB source that might accompany the presence of recycled oceanic crust. 914 Rather they indicate that the upper mantle source of these samples has experienced a long-term depletion of Re, similar to that observed in abyssal peridotites, and consistent with the incompatible nature of this element during mantle melting. 
922 The oceanic crust comprises some 1-1.5 km of basalt and dolerite that is underlain by $4-5 \mathrm{~km}$ of 923 gabbro. Therefore, mid-ocean ridge basalts are thought to be evolved lavas formed by fractional 924 crystallisation in the lower oceanic crust, that itself comprises plutonic rocks and cumulates, from primitive magmas. Given that Re is moderately incompatible while Os is compatible during mantle melting, one might expect that gabbros in the lower crust would have higher Os and lower Re concentration and accordingly low Re/Os ratios than evolved MORB assuming that the phases that control solid/liquid partitioning of $\mathrm{Re}$ and Os during crystallization are similar to those involved during partial melting. Gabbroic lower oceanic crust should therefore dominate the PGE budget of the oceanic crust as whole.

However, the first reported siderophile element data for gabbros from Ocean Drilling Program (ODP) Site 735 (Blusztajn et al., 2000) yielded rather low PGE concentrations (Figure 28), even lower than average MORB (Bezos et al., 2005; Gannoun et al., 2007) pointing to their evolved compositions. Indeed, Dick et al. (2000) and Hart et al. (1999) noted that the average composition of gabbro from ODP Site 735B is closer to that of average MORB (on the basis of major and trace element systematics). Consequently, the gabbro recovered at this site cannot be considered as the primitive complement to typical evolved MORB. More recently, Peucker-Ehrenbrink et al. (2012) have argued that all prior geochemical work on in situ upper oceanic crust such as DSDP-ODP sites 417, 418 and 504 (Bach et al., 2003; Peucker-Ehrenbrink et al., 2003), and 801 (Reisberg et al., 2008), and evolved gabbros at ODP 735 (Hart et al., 1999; Blusztajn et al., 2000), and site 894 (Lecuyer and Reynard, 1996) failed to reproduce the true average for the complementary crustal reservoir to MORB lavas and therefore needs to be complemented with more detailed geochemical and petrologic studies of primitive gabbroic material from the lower crust.

946 In order to more accurately assess the global HSE chemistry of the whole oceanic crust Peucker947 Ehrenbrink et al. (2012) obtained data for an oceanic crust section from the Oman ophiolite that 948 includes the crust-mantle transition. The mean weighted composition of the $4680 \mathrm{~m}$ Oman section 949 yielded Re 427 pg/g, Os 55pg/g, Ir 182 pg/g, Pd 2846 pg/g, Pt 4151 pg/g and initial ${ }^{187}$ Os $/{ }^{188}$ Os of 950 0.142, indicating higher PGE concentration and lower Re concentration than all data previously 951 reported on partial sections of ocean crust that lack cumulate lower crust. Assuming that these data 952 are truly representative of the lower oceanic crust then they suggest that these rocks are the main 
953 PGE reservoir in the oceanic crust as a whole and that the average Re in these gabbros is much lower 954 than in MORB lavas ( $\operatorname{Re} \sim 1070$ pg/g; Hauri and Hart, 1997; Gannoun et al., 2007; This chapter). The 955 Oman gabbros are characterised by a distinct subchondritic average Os/Ir ratio of $\sim 0.3$ which is significantly different from the chondritic ratio or the primitive upper mantle value of $\sim 1.1$ (Becker et al., 2006; Lodders et al., 2009). This difference is surprising because Ir is generally viewed as a geochemical analogue of Os during magmatic processes (Becker et al., 2006; Puchtel and Humayun, 2000). The Os/Ir fractionation observed in the Oman gabbros, while within the range observed in MORB (0.2-1.4 average 0.6), is the opposite of that observed in the upper crustal part from DSDP 504B (average Os/Ir of 2.4; Peucker-Ehrenbrink et al., 2003). However the Os/Ir of abyssal peridotites in general and in the harzburgitic mantle section of Oman in particular, remains chondritic (Hanghoj et al., 2010). If such harzburgites are representative of the mantle source then the subchondritic Os/Ir ratio in Oman gabbros cannot reflect a source signature. Hanghoj et al. (2010) report both superchondritic and subchondritic Os/Ir ratios in Oman dunites (0.5 - 8.3). As Os and Ir alloys included in chromites have been observed in Oman dunites (Ahmed and Arai, 2002; Ahmed et al., 2006), Peucker-Ehrenbrink et al. (2012) suggested that such a phase may be responsible for the fractionation of Os from Ir during melting, melt extraction or crystal fractionation.

Estimating the HSE inventory of the whole ocean crust remains challenging because of the discontinuous nature of the field sampling and the question of how representative are the samples that have been analysed thus far. Peucker-Ehrenbrink et al. (2012) used data from Site 504B for the upper oceanic crust (Peucker-Ehrenbrink et al., 2003) combined that for the Oman ophiolite for the lower oceanic crust (Peucker-Ehrenbrink et al., 2012). The weighted chemical and isotope characteristics of this "composite" oceanic crust (Figure 28), corrected for Re decay since emplacement, are $736 \mathrm{pg} / \mathrm{g}$ Re, 45 pg/g Os, 133 pg/g Ir, 2122 pg/g Pd, 2072 pg/g Pt, ${ }^{187} \mathrm{Re} /{ }^{188}$ Os: 80 and ${ }^{187}$ Os/ $/{ }^{188}$ Os: 0.144. Such crust is more enriched in Re and less depleted in PGE than observed in average gabbros from ODP Hole 735D. Therefore, unless fundamentally altered during subduction, subducted oceanic crust will evolve to form a PGE-depleted, Re-rich mantle component that over time will evolve to radiogenic ${ }^{187} \mathrm{Os} /{ }^{188} \mathrm{Os}$ isotope compositions. However, the projected ingrowth of radiogenic ${ }^{187} \mathrm{Os} /{ }^{188} \mathrm{Os}$ may be inhibited by the loss of Re from the basaltic upper part of the crust during eclogite-facies metamorphism (Becker et al., 2000; Dale et al., 2007) but not the gabbroic lower part of the crust (Dale et al., 2007). 
989 Recent work has shown that the crystallization of gabbros, troctolites and other plutonic rocks of the 990 lower oceanic crust may be protracted, and that these rocks sometimes possess ages that are several 991 million years older than predicted from the magnetic ages of the overlying basaltic crust (e.g. 992 Schwartz et al., 2005; Grimes et al., 2008). This extended timescale for the growth of the lower 993 oceanic crust has been attributed to the crystallisation of gabbros in the mantle followed by uplift to 994 lower crustal depths (Schwartz et al., 2005; Grimes et al., 2008). Such uplift may relate to unroofing 995 by low-angle detachment faults, typical of asymmetrical spreading ridge segments (e.g. Lissenburg et 996 al., 2009).

998 Over a timescale of several million years gabbros and troctolites, and their constituent phases, in the 999 lower oceanic crust will rapidly evolve to radiogenic Os isotope compositions. This raises the 1000 possibility that younger melts passing through older lower crust may acquire a radiogenic Os isotope composition, either by remelting and assimilation of older material or through the physical entrainment of older crystals. Primitive xenocrysts are commonly found in MORB (e.g. Dungan and Rhodes, 1978; Coogan, 2014) with evidence for mixing shortly before eruption (e.g. Moore et al., 2014). Indeed, as discussed previously, the old ages of phenocryst phases in basalts that are thought to have been erupted just 5 to $10 \mathrm{ka}$ (Figures 18 and 19), may indicate that these are rather xenocrysts physically entrained from previously solidified "olivine-plagioclase" bearing plutonic rocks through which the present host basalts have ascended. In this case, it is possible that some MORB glass may acquire a radiogenic Os isotope composition without interaction with seawater altered oceanic crust, or the presence of a radiogenic mantle source. For MORB glass such a signature might be distinguished by the absence of any covariation with $\mathrm{Cl}$ abundance or $\mathrm{B}$ isotopes. 
The HSE and Re-Os systematics of intraplate volcanism were reviewed recently by Day (2013). The purpose of this section is to briefly summarize the likely origins of intraplate volcanism, based specifically upon HSE abundance and Re-Os isotope constraints, and to provide a brief update of developments in the field since 2013. In particular, and mostly as a function of the difficulties associated with producing precise ${ }^{186} \mathrm{Os} /{ }^{188}$ Os data (e.g., Chatterjee and Lassiter, 2015), there has been no significant advances in the application of the Pt-Os isotope system to intraplate volcanism since Day (2013); the interested reader is referred to this earlier review article for an up to date appraisal of Pt-Os systematics.

The origin of intraplate volcanism has been variously attributed to (i) mantle plumes (Wilson, 1963; Morgan, 1971), (ii) plumes which are not particularly "hot” (e.g., Falloon et al., 2007; Putirka et al., 2007), (iii) stress-driven processes (Anguita and Hernan, 1975) or (iv) chemical heterogeneities preserved in the upper mantle (e.g., Courtillot et al., 2003; Arndt, 2012). The occurrence of intraplate volcanism does not appear to be related to proximity to plate boundaries (cf. Hawaii; Wilson, 1963 versus the Canary Islands; Morgan, 1971) and does not occur systematically on either the continents or within oceanic basins, even spanning continental-oceanic margins (i.e., the Cameroon Line; Rehkämper et al., 1997; Gannoun et al., 2015a). Intraplate volcanism can be associated with convergent (e.g. Samoa; Wright and White, 1987) and divergent (e.g. Iceland; Morgan, 1971) tectonic settings.

In general, intraplate volcanism is controlled by anomalous thermo-chemical and/or tectonic conditions capable of producing large volumes of extrusive products. Many investigations into the HSE of intraplate volcanic rocks have predominantly featured primitive, high-MgO rocks, e.g., komatiites and picrites (e.g. Connolly et al., 2011; Ireland et al., 2009, respectively), because of the compatibility of the HSE during fractional crystallisation, and the sensitivity of ${ }^{187} \mathrm{Os} /{ }^{188} \mathrm{Os}$ to crustal assimilation processes in more evolved magmas (e.g., Chu et al., 2013). However, evolved potassic and sodic mafic-alkaline volcanic rocks and phonolites, trachytes and rhyolites, which may have experienced extensive fractional crystallisation, are also observed and have recently been investigated for their HSE abundance and Re-Os isotope systematics (e.g., Chu et al., 2013; Li et al., 2014; Wang et al., 2014). For this reason, we adopt the same definition used by Day (2013) for intraplate 'hotspot' volcanism, i.e., "Volcanic rocks that are unassociated with conventional plate tectonic boundary magmatic processes and that may require anomalous thermo-chemical and/or tectonic conditions to induce small- to large-scale melting”. 


\section{Mantle melting processes}

The composition of the mantle source may be expressed by a variety of end-member compositions based upon its history of prior melt depletion i.e., depleted versus fertile peridotite 1057 (e.g., Niu, 2004; Godard et al., 2008) and overall lithology, i.e., peridotite versus pyroxenite 1058 (Hirschmann and Stolper 1996; Yaxley, 2000; Kogiso et al., 2004; Lambart et al., 2012, 2013). In 1059 addition, fertile heterogeneities in the mantle nucleate magmatic channels that focus melts up to the surface and hinder their re-equilibration with ambient peridotite (Katz and Weatherley, 2012). Therefore, the chemical signature of hybrid melts of peridotite and pyroxenite can be retained in the composition of mantle-derived basalts. Day (2013) discussed the significance of the 'shape' that a melting regime can have, discussing two end-member geometries; (i) batch melting of a columnar (cylindrical) region (e.g., Rehkämper et al., 1999), and (ii) regions of adiabatic melting in triangular or corner-flow melting regime (e.g., Plank and Langmuir, 1992). Each of these melting regimes aggregate melt pooled from over the melting volume, accounting for the overall composition of the magma generated.

Briefly, model (i) is most consistent with an upwelling 'mantle plume-like' melting regime. It assumes uniform melting throughout the source region and that HSE-rich sulfide is completely exhausted at 20-25\% partial melting. This cylindrical melting model reproduces the HSE abundances of low-degree alkali basalts (e.g., Canary Island lavas; e.g., Day et al., 2009) and high-degree partial melts (e.g., komatiites; e.g., Rehkämper et al., 1999), but the HSE signature of some tholeiitic magmas generated by low degrees of partial melting are not predicted using this cylindrical melt volume (e.g., Momme et al., 2003, 2006). The triangular melting regime (model ii) assumes nearfractional melting in $1 \%$ increments with decreasing pressure, i.e., through adiabatic ascent (e.g. Rehkämper et al., 1999; Momme et al., 2003). In this melting regime, S-saturated low-degree partial melts with low HSE-concentrations mix with shallower, higher-degree (and potentially Sundersaturated) partial melt. Refinements to the two general classes of models described above have allowed distinct melt regimes in some continental flood basalt (CFB) provinces to be determined (Momme et al., 2006), whereas in the Icelandic rift zones depleted versus enriched mantle components have also been identified (Momme et al., 2003). Moreover, the use of these models has permitted the detection of a pyroxenitic component in primitive lavas from the Canary Islands (Day et al., 2009), and a similar component has been implicated in the generation of some Hawaiian lavas 
Source compositional estimates become increasingly complicated when the necessity arises to account for the contributions from mixtures of source lithologies (e.g., peridotite and recycled sediment or basalt) and the complex interplay of the HSE that each of these source reservoirs may contribute to a pooled melt (e.g., Hirschmann and Stolper, 1996).

\section{Osmium isotopes as tracers of hotspot sources}

Ocean island basalts. Many intraplate basalts retain HSE signatures of their mantle source region and osmium isotopes, when compared to lithophile element-based radiogenic isotopes, can offer a unique perspective on the petrogenesis of intraplate lavas. The large Re/Os fractionations generated during crust-mantle partitioning make it possible to model ${ }^{187} \mathrm{Os} /{ }^{188} \mathrm{Os}$ variations in OIB in the context of variably aged recycled crust and lithosphere (e.g., Hauri and Hart, 1993; Marcantonio et al., 1995; Widom et al., 1999; Day et al., 2009; Day, 2013). For example, ancient oceanic mantle lithosphere or SCLM has been implicated in the genesis of lavas from the Azores, Iceland and Jan Mayen (Skovgaard et al., 2001; Schaefer et al., 2002; Debaille et al., 2009), where measured unradiogenic ${ }^{187} \mathrm{Os} /{ }^{188} \mathrm{Os}$ values cannot be explained by melting exclusively of modern oceanic lithospheric material and thus require a mantle source or sources that have evolved in a low Re/Os environment (cf. unradiogenic abyssal peridotites reported by Snow and Reisberg, 1995; Alard et al., 2005; Harvey et al., 2006; Liu et al., 2008; Warren and Shirey, 2012; Lassiter et al., 2014). Intraplate basalts and specifically ocean island basalts (OIB), are generated from mantle sources with distinct long-term time-integrated parent-daughter fractionations of $\mathrm{Sr}-\mathrm{Nd}-\mathrm{Pb}-\mathrm{Hf}$ isotopes (e.g., Zindler and Hart, 1986; Hofmann, 2003; White, 2010), and also preserve a large range of ${ }^{187} \mathrm{Os} /{ }^{188} \mathrm{Os}$ compositions (e.g., Pegram and Allègre, 1992; Hauri and Hart, 1993; Reisberg et al., 1993; Marcantonio et al., 1995; Roy-Barman and Allègre, 1995; Widom and Shirey, 1996; Lassiter and Hauri, 1998; Brandon et al., 1999, 2007; Widom et al., 1999; Schiano et al., 2001; Eisele et al., 2002; Schaefer et al., 2002; Lassiter et al., 2003; Workman et al., 2004; Escrig et al., 2005b; Class et al., 2009; Day et al., 2009, 2010b; Debaille et al., 2009; Ireland et al., 2009; Jackson and Shirey, 2011). These signatures are only retained in instances where the melt produced at depth, albeit with ancient time-integrated compositions, and reflecting the recycling of material back into the convecting mantle (e.g., Zindler and Hart, 1986), are not significantly contaminated or overprinted though interaction with the lithosphere through which these basalts necessarily transit en route to the surface. For example, in a recent study of the Louisville Seamount Chain, Tejada et al. (2015) demonstrated that OIB erupted along this chain of oceanic volcanoes reach the surface with negligible chemical interaction with the lithospheric mantle that underlies the South Pacific. Moreover, unlike the 
Hawaiian-Emperor Seamount chain, whose compositions are readily explained by heterogeneous mantle sources (see following section), Os isotope signatures of these basalts have a very narrow range, consistent with their derivation from a primitive mantle source (cf. Meisel et al., 2001; Becker et al., 2006). Age corrected ${ }^{187} \mathrm{Os} /{ }^{188} \mathrm{Os}$ of the Louisville Seamount basalts range from 0.1245 0.1314, similar to other Pacific OIB, such as Rarotonga (0.125-0.129, Hauri and Hart (1993); 0.1240.139, Hanyu et al. (2011) and some Samoan basalts (0.1230-0.1313, Hauri and Hart (1993); Jackson and Shirey (2011)). The age corrected ${ }^{187} \mathrm{Os} /{ }^{188}$ Os for two aggregates of olivine phenocrysts separated from Louisville Seamount basalts (0.1272 and $0.1271-0.1275)$ agree with whole rocks from the same seamount (0.1253-0.1274; Tejada et al., 2015), supporting the hypothesis that earlycrystallising olivine can preserve the pristine magmatic Os isotopic compositions of their source (cf. Jackson and Shirey, 2011; Hanyu et al., 2011) (Figure 29).

Studies of HSE abundance complement and extend the knowledge of intraplate magma petrogenesis gleaned from Os isotope systematics. Only lavas with high-MgO contents and $>0.05 \mathrm{ng}$ $\mathrm{g}^{-1}$ Os should be considered as potentially being representative of the true HSE characteristics of intraplate magma and its mantle source. Such restrictions on the analysis of intraplate magmas mean that there is still a dearth of high quality HSE data on OIB. Much of what has been elucidated from HSE abundances in OIB comes from studies of Hawaiian lavas (Bennett et al., 2000; Crocket, 2002; Jamais et al., 2008; Ireland et al., 2009; Pitcher et al., 2009). These studies support the hypothesis that, in general, high-MgO lavas preserve early-formed Os-rich (+ HSE) phases that become incorporated in early forming phenocrysts such as olivine (e.g., Brandon et al., 1999; Ireland et al., 2009). Removing the effects of mineral fractionation on HSE abundances allowed Day (2013) to directly compare the absolute and relative HSE abundances and calculated Re/Os of parent melts in addition to ${ }^{187} \mathrm{Os} /{ }^{188} \mathrm{Os}$, of Hawaiian, Canary Island and Samoan lavas. Combined with the HIMU type ${ }^{206} \mathrm{~Pb} /{ }^{204} \mathrm{~Pb}$ compositions of Canary Island lavas, this led to the conclusion that, in contrast to Hawaiian and Samoan OIB, and komatiites, whose compositions suggest a relatively high proportion of peridotite in their parental melts, lavas from the Canary Islands, and specifically El Hierro and La Palma, contain recycled oceanic crust in their mantle source. Osmium isotope studies of HIMU-type OIB support and enhance $\mathrm{Sr}-\mathrm{Nd}-\mathrm{Pb}$ isotope and trace element arguments for a recycled oceanic lithosphere component in their mantle source (Hauri and Hart, 1993; Marcantonio et al., 1995; Widom et al., 1999; Eisele et al., 2002; Day et al., 2010b). The observed range of ${ }^{187} \mathrm{Os} /{ }^{188}$ Os and ${ }^{206} \mathrm{~Pb} /{ }^{204} \mathrm{~Pb}$ of HIMU basalts (e.g., Becker et al., 2000; Dale et al., 2009a; van Acken et al., 2010) could be produced by direct melting ( $\sim 50 \%$ to $90 \%)$ of recycled oceanic crust, but would result in melts that contain too much silica and too little magnesium (e.g., Yaxley and Green, 1998). Although field evidence suggests that pyroxenites account for $\leq 10 \%$ of mantle lithologies (e.g., Reisberg et al., 
1153 1991; Pearson et al., 1991), they melt disproportionately to peridotite under any P-T conditions (only

11541 to $2 \%$ pyroxenite may generate up to $50 \%$ of the melt at low degrees of partial melting), thus 1155 producing silica-undersaturated, iron-rich melts with high MgO (e.g., Hirschmann et al., 2003). This 1156 means that direct melting of recycled oceanic crust and lithosphere is not necessary to produce HIMU 1157 OIB.

1158 Spinel websterites have been suggested to be geochemically analogous to pyroxenites, at least 1159 in terms of their HSE systematics (Marchesi et al., 2014). The Re-Os fractionation generated as a 1160 result of peridotite versus pyroxenite (and/or spinel websterites) has been suggested as a likely 1161 contributor to the observed ${ }^{186}$ Os- ${ }^{187}$ Os-rich compositions of some plume basalts (Luguet et al., 2008) 1162 previously attributed to interaction between the mantle and outer core (e.g., Brandon et al. 1998, 1163 2003; Puchtel et al., 2005; Walker et al., 1997). Subsequent studies (e.g., Baker and Jensen, 2004; 1164 Luguet et al., 2008; Scherstén et al., 2004) and, more recently, Marchesi et al. (2014) suggest that 1165 such enrichments could be attributed to processes requiring no input from the outer core. However, 1166 these models may require unreasonably high contributions from pyroxenitic / spinel websteritic 1167 lithologies in the mantle (as high as 90\% in some cases, but potentially as low as 50\%; van Acken et al., 2010; Marchesi et al., 2014), as a result of the comparatively low Os concentrations in pyroxenerich lithologies.

The enriched mantle (EM) signatures of other OIB have been attributed to the addition of 1171 subducted sediment or metasomatised lithosphere into their mantle sources (e.g., Workman et al., 1172 2004). EM-type OIB span a range of compositions in $\mathrm{Sr}-\mathrm{Nd}-\mathrm{Pb}$ isotope space, varying from EMI 1173 (e.g., Pitcairn; Woodhead and McCulloch, 1998; and the Comores; Class et al., 2009), which exhibit 1174 a wide range of $\mathrm{Os}$ and $\mathrm{Pb}$ isotope compositions, but more restricted $\mathrm{Sr}$ isotope compositions, to 1175 EMII OIB (e.g., Samoa; Wright and White, 1987; Workman et al., 2004; Jackson and Shirey, 2011). 1176 These compositions are consistent with sediment, recycled oceanic crust and peridotite producing 1177 EMI-flavoured compositions with more radiogenic ${ }^{187} \mathrm{Os} /{ }^{188}$ Os (Roy-Barman and Allègre, 1995; 1178 Class et al., 2009), while subducted sediment mixed with ambient peridotite produces enriched EMII 1179 compositions with lower ${ }^{187} \mathrm{Os} /{ }^{188} \mathrm{Os}$. Therefore, lithological variations in the mantle source play a 1180 key role in the composition of OIB, and HSE abundances combined with Re-Os systematics are 1181 critical in the identification of the various components mixed with variably depleted asthenospheric mantle.

Continental intraplate volcanism. The heterogeneous mantle sources described above are not restricted to OIB, or oceanic settings in general. These modifiers of magma composition also 1186 influence intraplate volcanism associated with continental regions. The main differences between 
oceanic and continentally erupted intraplate magmas is the greater potential for the latter to be influenced by interaction with the thicker and older overlying sub-continental lithospheric mantle (SCLM) and continental crust, in addition to the potential compositional heterogeneities within the asthenospheric mantle. Recently, Sun et al. (2014) reported Re-Os systematics of ultrapotassic (>7 wt. $\% \mathrm{~K}_{2} \mathrm{O}$ ) basalts from the Xiaogulihe area of western Heilongjiang Province, NE China. The relatively unradiogenic Os isotope ratios $\left({ }^{187} \mathrm{Os} /{ }^{188} \mathrm{Os}=0.119\right.$ to 0.143$)$ contrasted with the similarly potassic basalts from NE China reported by Chu et al. (2013) $\left({ }^{187} \mathrm{Os} /{ }^{188} \mathrm{Os}=0.13-0.17\right)$ and were attributed by Sun et al. (2014) to a dominantly peridotitic source, but one that required an unusually high $\mathrm{K}_{2} \mathrm{O}$ content. In this particular setting, phlogopite-bearing garnet peridotite hosted within the lower part of the SCLM was implicated; its derivation being potassium-rich silicate melts produced by the subduction of ancient continent-derived sediments $(>1.5 \mathrm{Ga})$. The observation that lherzolite xenoliths from Keluo and Wudalianchi contain phlogopite (Zhang et al., 2000, 2011) supports the hypothesis that SCLM, metasomatized by potassium-rich melts, is present beneath the WEK volcanic field and contributes to the basalts from Xiaogulihe.

\section{Crustal and lithospheric mantle assimilation/contamination}

Oceanic intraplate volcanism is often assumed to be immune to lithospheric contamination. Compared to continental intraplate eruptions, OIB do not interact with thermo-chemically complex SCLM. The low Os contents in OIB (typically $<1 \mathrm{ng} \mathrm{g}^{-1}$ ) makes the Re-Os isotope system a particularly sensitive indicator of lithospheric contamination, and the relatively unradiogenic ${ }^{187} \mathrm{Os} /{ }^{188} \mathrm{Os}$ compositions $(<0.18)$ of OIB relative to local oceanic crustal reservoirs (typically ${ }^{187}$ Os $/{ }^{188}$ Os $>0.4$; Reisberg et al., 1993; Marcantonio et al., 1995; Peucker-Ehrenbrink et al., 1995; Widom et al., 1999) make the tracing of assimilation of crustal or lithospheric mantle materials in

1211 OIB a straightforward process (e.g., Reisberg et al., 1993; Marcantonio et al., 1995; Lassiter and 1212 Hauri, 1998; Skovgaard et al., 2001; Gaffney et al., 2005). In particular, at the lowest levels of Os content, OIB are even more vulnerable to crustal contamination (Reisberg et al. 1993), while OIB with Os contents greater than 30 to $50 \mathrm{pg} \mathrm{g}^{-1}$ are typically assumed to be less susceptible to assimilation of lithospheric components (e.g., Reisberg et al., 1993; Eisele et al., 2002; Class et al., 2009). Crustal contamination thus rapidly drives Os isotope ratios to more radiogenic values resulting from the assimilation of oceanic crust with high Re/Os and ${ }^{187} \mathrm{Os} /{ }^{188} \mathrm{Os}$.

A consequence of the low HSE abundances of crustal material is that the addition of crust to a primitive melt should result in the dilution of HSE abundances in the resultant magma. Ireland et al. (2009) presented such a model, illustrating the effect of crustal contamination on Hawaiian picrites. 
1221 Briefly, three end-member scenarios are considered; (i) continental crust addition to komatiite; (ii) 1222 oceanic crust addition to tholeiite and, (iii) abyssal peridotite addition to alkali basalt. These models demonstrate that crustal contamination dilutes OIB HSE abundances at $\leq 20 \%$ crustal or lithospheric assimilation. However, both ${ }^{187} \mathrm{Os} /{ }^{188} \mathrm{Os}$ and Re/Os can change dramatically in the evolving liquid, which has implications for the time integrated Os isotope ratio of such contaminated magmas and the effectiveness of using ${ }^{187} \mathrm{Os} /{ }^{188} \mathrm{Os}$ as a tracer for the mantle source of the magma. The effects of assimilation on HSE abundances (absolute or relative) in general, are less well-defined and where this issue has been addressed in the literature the consensus appears to be that fractional crystallisation exerts a stronger influence on HSE distributions than contamination factors (e.g., Chazey and Neal, 2005; Ireland et al., 2009). However, crustal contamination of continental flood basalts (CFB) can lead to a significant augmentation in the $\mathrm{S}$ content of a magma, sometimes resulting in S-saturation and significant HSE fractionation (e.g., Keays and Lightfoot, 2007; Lorand and Alard, 2010). This may also elevate concentrations of Re and the PPGE relative to Os, Ir and Ru. Assimilation of mantle lithosphere also has pronounced effects on Re/Os, but requires large additions to generate significant effects on magma HSE abundances. Conversely, Widom et al. (1999) demonstrated that unusually unradiogenic ${ }^{187} \mathrm{Os} /{ }^{188} \mathrm{Os}$ in some Canary Island lavas was most likely the result of the assimilation of peridotite xenoliths with sub-chondritic ${ }^{187} \mathrm{Os} /{ }^{188} \mathrm{Os}$ and $>1 \mathrm{ng} \mathrm{g}^{-1} \mathrm{Os}$, prior to the eruption of the basalt at the surface. More recently, a similar process was described by

1239 Gannoun et al (2015a) to account for particularly unradiogenic Os concentrations in basalts from the Cameroon Line (Figure 30).

These simple crustal contamination models can be greatly complicated by the inclusion of fractional crystallisation processes, which are often intimately associated with crustal contamination. The combination of these processes will almost inevitably result in the generation of elevated $\mathrm{Re}, \mathrm{Pt}$ and $\mathrm{Pd}$ abundances compared to $\mathrm{Os}$, $\mathrm{Ir}$ and $\mathrm{Ru}$ in melts and crustal rocks, compared with their corresponding mantle residues. However, direct measurement of ${ }^{187} \mathrm{Os} /{ }^{188} \mathrm{Os}$ in early formed mineral 1246 phases handpicked from intraplate magmas, such as olivine (Debaille et al., 2009; Jackson and 1247 Shirey, 2011), generally yield more restricted ranges in ${ }^{187} \mathrm{Os} /{ }^{188}$ Os than their associated whole-rocks, 1248 and may provide a means of seeing past bulk-rock contamination of OIB. As a result of these potential complications, a common sense approach, based upon a rigorous assessment of local potential contaminants and melt products was advocated by Day (2013) when applying thresholds for “contaminated" versus "uncontaminated" OIB. Both crustal and SCLM contamination of primitive melts have been reported in the literature (e.g., Ellam et al., 1992; Horan et al., 1995; Molzahn et al., 1253 1996; Chesley and Ruiz, 1998; Keays and Lightfoot, 2007; Li et al., 2010; Chu et al., 2013). 1254 Successful modelling of SCLM or crustal assimilation is dependent upon the accurate determination 
1255 of likely end-member compositions, ranging from the parental primitive melt to its possible assimilants. Day (2013) successfully demonstrated the effect of contamination of primitive parent melts using North Atlantic Igneous Province (NAIP) picrites (Schaefer et al., 2000; Kent et al., 2004; Dale et al., 2009b) and intrusive rocks from the Rum Intrusion (O’Driscoll et al., 2009).

\section{The origin of Continental Flood basalts (CFB) and Large Igneous Provinces (LIP)}

Volcanic rocks from some CFB have been interpreted to have survived the transit from their asthenospheric source to eruption at the surface without any significant interaction with the SCLM or the crust (e.g., Schaefer et al., 2000; Zhang et al., 2008; Dale et al., 2009b; Rogers et al., 2010; Day et al., 2013). Many of these lavas are picritic in composition, have high-MgO (>13.5 wt. \%), high Os concentrations, and ${ }^{187} \mathrm{Os} /{ }^{188} \mathrm{Os}$ ratios which are, in general, unradiogenic; consistent with their derivation from primitive mantle or a depleted mantle source (e.g., Schaefer et al., 2000; Dale et al., 2009b; Rogers et al., 2010). This chemical and isotopic signature has, in turn, been used to suggest that such CFB may be modern-day equivalents of uncontaminated Archaean komatiites, albeit from a cooler mantle, (cf., Brügmann et al., 1987; Wilson et al., 2003; Puchtel et al., 2009; Connolly et al., 2011).

In contrast, several studies have highlighted the importance of an interaction between asthenosphere-derived melts, SCLM and the crust to produce the observed spectrum of CFB compositions (e.g., Ellam et al., 1992; Horan et al., 1995; Molzahn et al., 1996; Chesley and Ruiz, 1998; Xu et al., 2007; Li et al., 2010; Heinonen et al., 2014) and the HSE fingerprint of some komatiites (Foster et al., 1996). Osmium isotope systematics, combined with other radiogenic isotope tracers in CFB demonstrate that the interplay between a primary magma and its potential lithospheric contaminants can be complex, as illustrated in a number of localities (e.g., Siberia - Horan et al., 1995; Ethiopia - Rogers et al., 2010; Emeishan, China, - Zhang et al., 2008). Correlations between ${ }^{187} \mathrm{Os} /{ }^{188} \mathrm{Os}$ and ${ }^{87} \mathrm{Sr} /{ }^{86} \mathrm{Sr}$ (Molzahn et al., 1996), ${ }^{206} \mathrm{~Pb} /{ }^{204} \mathrm{~Pb}$ (Xu et al., 2007), and possibly even ${ }^{3} \mathrm{He} /{ }^{4} \mathrm{He}$ (Dale et al., 2009b) illustrate the effects of lithospheric contamination on primary, asthenosphere-derived melts. However, observed variations in Os isotopes are not wholly consistent with SCLM or crustal contamination alone, suggesting that, like many OIB, some inherent heterogeneity within the asthenospheric source is present. For example, the $260 \mathrm{Ma}$ Emeishan province (e.g., Li et al., 2010) requires a more depleted mantle source than 190 Ma Karoo CFB (Ellam et al., 1992). Some CFB provinces may therefore tap mantle sources that contain recycled material, similar to the source of some HIMU and EM flavoured OIB (e.g., Shirey, 1997; Dale et al., 2009b), while others are derived from an essentially primitive mantle (see review in Day, 2013). 
Heterogeneity in the composition and distribution of sulfide types within a magma source region in the mantle (e.g., interstitial versus enclosed sulfides; Alard et al., 2002; see also Harvey et al., 2015, this volume) can have a profound influence on the composition of a basaltic melt (e.g. Harvey et al., 2010, 2011). The combination of source heterogeneity and degree of partial melting can therefore account for the observed differences in initial Os isotopic and HSE abundance variations in CFB provinces, that range from depleted DMM-like mantle compositions (e.g., Rogers et al., 2010) through undepleted basalts (e.g., Schaefer et al., 2000), to more radiogenic compositions, which provide strong evidence for recycled components in some CFB provinces (Shirey, 1997).

Coupled with the effects of adding subducted oceanic lithosphere back into the convecting mantle, i.e. the source of CFB and LIP, and the combinations of pelagic / terrigenous sediments, variably altered oceanic crust and serpentinized peridotite (Allègre and Turcotte, 1986), unravelling the sources of voluminous basaltic magmatism has sometimes been demonstrated to be problematic, often requiring both HSE and Re-Os isotope evidence used in concert with more traditional lithophile element-based isotope systems. For example, Heinonen et al. (2014) invoked a mixture of depleted Os-rich peridotite with $\sim 10-30 \%$ of seawater-altered and subduction-modified MORB (with a recycling age of less than $1.0 \mathrm{Ga}$ ) as the likely source of the distinctive isotopic fingerprint found in CFB from the Antarctic Karoo province. A specific mixed peridotite-pyroxenite-like source was required to explain the unusual combination of elevated initial ${ }^{87} \mathrm{Sr} /{ }^{86} \mathrm{Sr}$ and $\mathrm{Pb}$ isotopic ratios, and low initial ${ }^{187} \mathrm{Os} /{ }^{188} \mathrm{Os}$ observed in the dykes sampled from around Ahlmannryggen, western Dronning Maud Land. In other words, simple, two-component mixing is often not consistent with the observed chemical and isotopic composition of CFB. In the example described by Heinonen et al. (2014), not only was a combination of mixed lithologies in the source, in addition to the inherent differences in their HSE and ${ }^{187} \mathrm{Os} /{ }^{188} \mathrm{Os}$ fingerprints required to account for the composition of the Ahlmannryggen dykes, but also a contribution from a seawater-altered subducted component was required. Magmatic Province (CAMP) by Merle et al. (2014) also revealed the complex combination of chemical and isotopic fingerprints that can be preserved in large-volume basaltic eruptions. Although CAMP magmatism in general may have been produced as a result of either heat incubation under thick continental lithosphere (McHone, 2000; De Min et al., 2003; Puffer, 2003; McHone et al., 2005; Verati et al., 2005; Coltice et al., 2007), or by a plume head under the continental lithosphere (May, 1971; Morgan, 1983; White \& McKenzie, 1989; Hill, 1991; Wilson, 1997; Courtillot et al., 1999; Ernst \& Buchan, 2002; Cebria et al., 2003), Merle et al. (2014) proposed several increasingly complex scenarios to account for the chemical and isotopic signatures preserved in the ENA CAMP 
1323 basalts, including (i) direct derivation from a mantle plume (Wilson, 1997) or oceanic plateau basalt1324 type melts (e.g. Kerr \& Mahoney, 2007); (ii) magmas derived from a mantle plume but contaminated by continental crust en route to the surface (Arndt al., 1993); (iii) mixing between asthenospheric and ultra-alkaline mafic (lamproite, kimberlite, and kamfugite) melts (Arndt \& Christensen, 1992; Gibson et al., 2006; Heinonen et al., 2010), possibly followed by crustal contamination; (iv) ternary mixing between OIB, MORB and SCLM-related melts, possibly followed by crustal contamination; (v) direct melting of a shallow source enriched in incompatible elements such as metasomatized SCLM or the mantle wedge above subduction zones (Puffer, 2001; De Min et al., 2003; Deckart et al. 2005; Dorais \& Tubrett, 2008). Unfeasibly large degrees of crustal contamination would be required to produce the observed ${ }^{143} \mathrm{Nd} /{ }^{144} \mathrm{Nd},{ }^{206} \mathrm{~Pb} /{ }^{204} \mathrm{~Pb}$ and ${ }^{208} \mathrm{~Pb} /{ }^{204} \mathrm{~Pb}$ isotopic compositions of the ENA CAMP basalts, and crustal contamination, assimilation (of continental crust) with fractional crystallization (DePaolo, 1981) and assimilation through turbulent ascent were discounted on the strength of the Re-Os and ${ }^{187} \mathrm{Os} /{ }^{188} \mathrm{Os}$ systematics i.e., initial ${ }^{187} \mathrm{Os} /{ }^{188} \mathrm{Os}$ ratios higher than 0.15 at Os concentrations lower than $50 \mathrm{ng} \mathrm{g}^{-1}$ (e.g., Widom, 1997).

Merle et al. (2014) determined that mixing involving either OIB or MORB-like parental melts, followed by crustal contamination, partially reproduces the compositions of the ENA CAMP basalts, but the trends observed in the $\mathrm{Nd}-\mathrm{Pb}$ and $\mathrm{Os}-\mathrm{Nd}$ isotopic diagrams require the addition of up to $35 \%$ continental crust, yet the assimilation of more than $20 \%$ of continental crust is 1341 thermodynamically unrealistic (Spera \& Bohrson, 2001). Consequently, the hypothesis of a magma originating from mixing between OIB and SCLM-related melts and further contaminated by the continental crust was deemed unlikely. Therefore, the continental crust-like characteristics of the ENA CAMP were inferred to be present in the mantle source itself. Recent studies have suggested that such contrasting chemical characteristics may be derived from a metasomatized SCLM-type source (cf. Chu et al., 2013; Sun et al., 2014; Wang et al., 2014), where phlogopite in the SCLM was thought to be derived from the melting of subducted terrigenous sediments. To account for the measured Os isotope compositions of the ENA CAMP basalts, the Os isotopic composition of the source needed to be within the range of ${ }^{187} \mathrm{Os} /{ }^{188}$ Os for off-cratonic SCLM $(0 \cdot 1180$ to $0 \cdot 1290$; Carlson, 2005), therefore the model favored by Merle et al. (2014) to explain the multi-isotope system fingerprint of the EMA CAMP basalts required a reservoir that experienced progressive incorporation of subducted sediments derived from the local continental crust into a depleted sub-arc mantle wedge above a subduction zone.

Recent work has revealed that HSE abundances can be broadly modelled as a function of 1355 fractional crystallization in CFB. Day et al. (2013) studied the 1.27 Ga Coppermine CFB in northern 1356 Canada, which represents the extrusive manifestation of the Mackenzie large igneous province (LIP), 
which includes the Mackenzie dyke swarm and the Muskox layered intrusion. These authors reported new HSE abundance and Re-Os isotope data for picrites and basalts from the CFB, as well as a highly unusual andesite glass flow. The glass contained high HSE contents (e.g., $3.8 \mathrm{ng} \mathrm{g}^{-1} \mathrm{Os}$ ) and mantle-like initial ${ }^{187} \mathrm{Os} /{ }^{188} \mathrm{Os}\left(\gamma_{1270 \mathrm{Ma}} \mathrm{Os}=+2.2\right)$, but $\delta^{18} \mathrm{O}, \varepsilon \mathrm{Nd}_{\mathrm{i}}$, and trace element abundances consistent with extensive crustal contamination, implicating a potential origin for sample CM19 as a magma mingling product formed within the Muskox Intrusion during chromitite genesis (cf. Day et al., 2008) and direct evidence for the processing of some CFB within upper-crustal magma chambers. These authors also modelled absolute and relative HSE abundances in CFB from the Coppermine, Parana and West Greenland, revealing that HSE concentrations decrease with increasing fractionation for melts with $<8 \pm 1 \mathrm{wt}$.\% $\mathrm{MgO}$ (Figure 31). The models reveal that significant interelement fractionation between $(\mathrm{Re}+\mathrm{Pt}+\mathrm{Pd}) /(\mathrm{Os}+\mathrm{Ir}+\mathrm{Ru})$ are generated during magmatic differentiation in response to strongly contrasting partitioning of these two groups of elements into sulfides and/or HSE-rich alloys. Furthermore, fractional crystallization has a greater role on absolute and relative HSE abundances than crustal contamination under conditions of CFB petrogenesis due to the dilution effect of low total HSE continental crust. Day et al. (2013) found that picrites (>13.5wt.\% MgO) from CFB ( $\left.\mathrm{n}=98 ; 1.97 \pm 1.77 \mathrm{ng} \mathrm{g}^{-1}\right)$ having higher Os abundances than OIB picrites $\left(n=75 ; 0.95 \pm 0.86 \mathrm{ng} \mathrm{g}^{-1}\right)$ and interpreted these differences to reflect either higher degrees of partial melting to form CFB, or incorporation of trace sulfide in CFB picrites from magmas that reached S-saturation in shallow-level magma chambers.

\section{Continental intraplate alkaline volcanism}

Continental intraplate alkaline volcanic rocks (CIAV) comprise a wide spectrum of sodic and potassic compositions ranging from alkali basalts, picrites and basanites through to more evolved eruptive products that include nephelinites, carbonatites, melilitites, and kimberlites. The origin of some of these rock types are not unequivocal, with petrogenetic models ranging from pure incipient rift-related sources (e.g., Thompson et al., 2005), to 'hotspot' or 'plume' related origins (e.g., Haggerty, 1999). Finding a likely source for these volcanic rocks is not made any less ambiguous when experimental and geochemical data are considered as many of these lavas are thought to derive from close to the boundary layer that separates the convecting and conducting mantle (e.g., Foley, 1992; Day et al., 2005), i.e. both the asthenosphere and SCLM can be implicated in the genesis of these magmas. Re-Os isotope data are limited for these types of lavas, and instances where this is combined with HSE abundance data are comparatively rare. Examples from the literature when HSE and / or Re-Os isotope data are available are summarized in Day (2013). 
When elevated osmium contents in basalts clearly exclude the influence of crustal contamination, radiogenic ${ }^{187} \mathrm{Os} /{ }^{188} \mathrm{Os}$ (e.g., >0.15) is often interpreted as being derived from olivinepoor mantle heterogeneities, such as clinopyroxenites (Carlson et al., 1996; Carlson and Nowell, 2001; Janney et al., 2002), primarily as a result of their time-integrated ingrowths to high ${ }^{187} \mathrm{Os} /{ }^{188} \mathrm{Os}$ (Reisberg et al., 1991; Reisberg and Lorand, 1995; Kumar et al., 1996). At the onset of S-saturated melting at depth, these fertile heterogeneities with radiogenic Os isotopic compositions melt preferentially (Hirschmann et al., 2003; Rosenthal et al., 2009). Combined with the Os isotope and HSE signature associated with pyroxenite-dominated melts, high $\mathrm{NiO}$ and low $\mathrm{MnO}$ concentrations in olivine phenocrysts are also diagnostic of olivine-poor mantle domains such as phlogopite-rich pyroxenites (Prelević et al., 2013). These phlogopite-bearing pyroxenites can be derived from the reaction of peridotitic mantle wedge with melts derived from terrigenous sediments, possibly from the uppermost regions of the subducting slab (Prelević et al., 2015). As such, many CIAV appear to have non-peridotitic sources, with some sodic mafic-alkali magmas possessing radiogenic ${ }^{187} \mathrm{Os} /{ }^{188} \mathrm{Os}$ compositions, but moderately high Os contents ( $\left.>0.5 \mathrm{ng} \mathrm{g}^{-1} \mathrm{Os}\right)$. Extreme Os isotopic compositions could reflect low degrees of partial melting and preferential sampling of more fusible mafic components, such as pyroxenite, in the asthenospheric mantle (cf. CFB above). Alternatively, melting of metasomatised lithosphere during rifting events (e.g., Carlson and Nowell, 2001; Thompson et al., 2005) may also be responsible for the PGE abundances and Re-Os systematics of some CIAV, such as the Newer volcanic rocks, Australia (Vogel and Keays, 1997). Similarly, carbonatites may also ultimately originate from mafic as opposed to ultramafic sources due to their close association with other ultrapotassic rocks (e.g., Gudfinnsson and Presnall, 2005). For example, young (>20 Ma) carbonatites from Fuerteventura, Canary Islands, possess low Os abundances (5 to $15 \mathrm{pg} \mathrm{g}^{-1}$ ) and highly radiogenic ${ }^{187} \mathrm{Os} /{ }^{188} \mathrm{Os}$ that extend to values in excess of 0.6 (Widom et al., 1999). Conversely, the high Os abundance and unradiogenic Os isotope signatures of some kimberlites and katungites are consistent with a petrogenesis involving the assimilation or derivation from the SCLM (Pearson et al., 1995; Carlson et al., 1996; Araujo et al., 2001; Carlson and Nowell, 2001; Pearson et al., 2008). More recently, Chalapathi Rao et al (2013) provided strong evidence for contrasting mantle sources for kimberlites and lamproites in the Eastern Dharwar craton, southern India. Re-Os isotope of orangeites from the Bastar craton and Mesoproterozoic kimberlites and lamproites contrasted with an unradiogenic Re-depleted kimberlite sample with present-day ${ }^{187} \mathrm{Os} /{ }^{188} \mathrm{Os}(0.1109)$ and a Re-Os isotopic fingerprint characteristic of Proterozoic lithosphere, with the positive $\gamma \mathrm{Os}$ (2.9 to 3.6) of two kimberlites from Raichur and Narayanpet (Eastern Dharwar craton) that retained both both plume and subduction-related source signatures (cf. Heinonen et al. 2014 for the petrogenesis of continental 1424 flood basalts from the Antarctic province of the Karoo). The enriched Re-Os mantle sources for the 
nearby Kodomali orangeite $(\gamma \mathrm{Os}=+3)$ and the Krishna lamproites, with very radiogenic $(\gamma \mathrm{Os} 56+$ 355), similar to those displayed by the lamproites of the Italian peninsula (Conticelli et al., 2007), suggest a subducted component for the latter ultra-potassic rocks, demonstrating the complex interplay of likely sources contributing to magma genesis around the Eastern Dharwar craton in both time and space (Chalapathi Rao et al., 2013).

The low Os concentrations of primary low-degree potassic and sodic mafic-alkali volcanic rocks, combined with the high Os abundance of mantle and crustal xenoliths in some kimberlites, alnoites and melnoites make these volcanic rocks highly susceptible to contamination as they pass through and interact with the SCLM and overlying crust. Evolved magmas of this type may also be susceptible to the effects of S-saturation prior to eruption (Vogel and Keays, 1997), i.e. they may have experienced the prior precipitation of sulfide and concomitant harvesting of HSE from the Ssaturated magma. Despite these caveats, some continental intraplate magmas still retain unique information on the composition of their mantle source. In particular, early Cretaceous alkaline picrites and basalts from the North China craton have petrological and Os-Sr-Nd isotope compositions consistent with contributions from recycled and foundered eclogitic lower continental crust (Gao et al., 2008). More recently, Chu et al. (2013) examined a suite of highly potassic basalts from Wudalianchi-Erkeshan, NE China and, despite the incorporation of modest amounts of continental crust and the potential of sulfide contamination derived from the SCLM, traced the source of the basalts back to the asthenosphere. Their findings suggested a complex interaction between crust and SCLM with highly potassic melts generated at least partly from SCLM containing phlogopite, itself with an ancient terrigenous sediment signature (Sun et al., 2014). In contrast to a predominantly peridotitic phlogopite-bearing source for continental volcanism reported by Sun et al. (2014), Miocene ultrapotassic rocks within the Sailipu area of the western Lhasa terrane, southern Tibet, were variously attributed to the interaction of both spinel- and garnet-lherzolite derived melt with a phlogopite-bearing pyroxenite source (Wang et al. 2014). Although the latter study postulated that the observed chemistry of the ultramafic melts could be attributed to crustal contamination, unfeasibly large-scale assimilation of continental crust would be necessary to account for the nature of the Sailipu basalts. While the lithophile element-based isotope systems are relatively insensitive to crustal contamination, mixing calculations using HSE concentrations and ${ }^{187} \mathrm{Os} /{ }^{188} \mathrm{Os}$ of primitive arc compositions (Os = $0.2 \mathrm{ng} \mathrm{g}^{-1} ;{ }^{187} \mathrm{Os} /{ }^{188} \mathrm{Os}=0.125$; Shirey and Walker, 1998; Suzuki et al., 2011), continental crust $\left(\mathrm{Os}=0.01 \mathrm{ng} \mathrm{g}{ }^{-1} ;{ }^{187} \mathrm{Os} /{ }^{188} \mathrm{Os}=1.10\right.$; Shirey and Walker, 1998) and depleted mantle material (Os $=0.405 \mathrm{ng} \mathrm{g}^{-1} ;{ }^{187} \mathrm{Os} /{ }^{188} \mathrm{Os}=0.108$; Shirey and Walker, 1998) demonstrated that the composition of the samples from western Lhasa (Wang et al., 2014) would require an unreasonably high degree of crustal contamination $(>80 \%$ ) (Figure 32). Two other studies of ultrapotassic rocks 
1459

1460

1461

1462

1463

1464

1465

1466

1467

1468

1469

1470

1471

1472

1473

1474

1475

1476

1477

1478

1479

1480

1481

1482

1483

1484

1485

1486

1487

1488

1489

1490

1491

1492

from Italy and the Balkans (Conticelli et al., 2007; Prelević et al., 2015, respectively) attributed a similar combination of mantle sources (as opposed to crustal contamination) as being primarily responsible for the observed chemical and isotopic compositions.

The recent study of Chu et al. (2013) also discussed the complex chemical and isotopic signatures preserved in the Wudalianchi-Erkeshan highly potassic basalts in the context of crustal and lithospheric contamination. Here, the range of ${ }^{187} \mathrm{Os} /{ }^{188} \mathrm{Os}$ in basalts $\left({ }^{187} \mathrm{Os} /{ }^{188} \mathrm{Os}=0.1187-0.17\right)$ was partially attributed to 2-8\% crustal contamination; a degree of assimilation that otherwise would be difficult to detect using lithophile element isotope systems. In fact, Gannoun et al. (2015a) suggested that degrees of crustal assimilation of up to $15 \%$ would have no measureable effect on $\mathrm{Nd}$ and $\mathrm{Pb}$ isotope ratios of basalts, while $\mathrm{Li}$ et al. (2014) commented that lithophile element-based isotope systems may be opaque to as much as $18 \%$ crustal contamination. In the latter study, high $\mathrm{NiO}$ and $\mathrm{SiO}_{2}$ contents, but low $\mathrm{MnO}, \mathrm{CaO}, \mathrm{MgO}$ and $\mathrm{Pb}$ contents, in addition to radiogenic ${ }^{187} \mathrm{Os} /{ }^{188} \mathrm{Os}$, low Os abundances (5 to $43 \mathrm{ng} \mathrm{g}^{-1}$ ) and high, but variable, Re/Os (3 to 126) of intra-continental OIB-like basalts from West Qinling, central China, were attributed to crustal contamination on the strength of the sensitivity of Os isotope systematics to the incorporation of continental crust.

In contrast, the most unradiogenic Os isotope signatures observed in continental alkaline intraplate volcanism may have been affected by the assimilation of xenocryst-hosted primary sulfide. The often unradiogenic ${ }^{187} \mathrm{Os} /{ }^{188} \mathrm{Os}$ and high $\left(>\mu \mathrm{g} \mathrm{g}^{-1}\right)$ Os content of sulfides enclosed within olivine xenocrysts (Alard et al., 2002) are prime candidates for the source of a possible "nugget effect". For example, a $20 \mu \mathrm{g}$ mantle sulfide with an Os concentration of $20 \mu \mathrm{g} \mathrm{g}^{-1}$ (see Alard et al., 2000, 2002; Pearson et al., 2002; Harvey et al., 2006, 2010, 2011; Lorand et al., 2013; Harvey et al., 2015, this volume for typical sulfides) contains twice as much Os as $2 \mathrm{~g}$ of basalt with an Os concentration of $100 \mathrm{pg} \mathrm{g}^{-1}$. This type of nugget effect was attributed by Chu et al. (2013) as being responsible for the poor reproducibility of ${ }^{187} \mathrm{Os} /{ }^{188} \mathrm{Os}$ in two Wudalianchi-Erkeshan basalts (LHS-6 and HSS-6). In this instance, the heterogeneous distribution of a component that contains anomalously high Os (+ PGE) abundances throughout the sampled rock powder could account for the observed heterogeneities in replicate basalt analyses. A similar source of heterogeneity was suggested by Gannoun et al. (2015a) to account for comparable unradiogenic ${ }^{187} \mathrm{Os} /{ }^{188} \mathrm{Os}$ signatures in some Cameroon Line basalts.

\section{Processes affecting the HSE compositions of sub-aerial volcanism}

The previous sections demonstrate that it is essential to consider the many possible source and contamination factors that may influence the ultimate composition of intraplate magmas. Irrespective of the tectonic setting in which an erupted magma was generated, sub-aerially erupted lavas may be 
1493

1494

1495

1496

1497

1498

1499

1500

1501

1502

1503

1504

1505

1506

1507

1508

1509

1510

1511

1512

1513

1514

1515

1516

1517

1518

1519

1520

1521

1522

1523

1524

1525

1526

subject to an additional group of processes whose affects need to be assessed prior to interpretations concerning magma sources and potential contaminants. These processes, including post-emplacement alteration and magmatic degassing, were reviewed comprehensively in Day (2013). While there has been a dearth of new data in the intervening period, one study in particular merits attention; the recent examination of Os loss through magmatic degassing at Piton de la Fournaise, Réunion Island (Gannoun et al., 2015b).

Oceanic island basalts have lower Re concentrations than MORB. This is anomalous considering the incompatible behavior of Re during basalt petrogenesis (Hauri and Hart, 1997). This apparent quirk has been attributed to two possible causes; (i) the presence of garnet and/or sulfide in their mantle source (Righter and Hauri, 1998), or (ii) magmatic degassing of Re (Bennett et al., 2000; Lassiter, 2003; Norman et al., 2004). Several lines of evidence support the idea that Re loss is a late and shallow stage process, which favors process (i) above. For example, an increase in oxygen fugacity promotes the loss of Re from Re metal (Borisov and Jones, 1999), suggesting that at the oxidation state relevant to OIB (FMQ), the rate of Re loss from a magma will increase by an order of magnitude per log unit of $\mathrm{fO}_{2}$ increase. Sub-aerial eruptions from Réunion and Hawaii preserve evidence for an increase in $\mathrm{fO}_{2}$ in the lavas during emplacement, from FMQ -1.8 close to eruption vents, to up to FMQ +3 in lava samples that have travelled several $\mathrm{km}$ and cooled slowly (Rhodes and Vollinger, 2005; Boivin and Bachélery, 2009).

Although Re and Os have the highest elemental condensation temperature (1821 and $1812 \mathrm{~K}$, respectively; Lodders, 2003), these elements are commonly enriched in volcanic gas sublimates and aerosols (Crocket, 2000; Yudovskaya et al., 2008; Mather et al., 2012). However, the relative and absolute volatilities of Re and Os, and hence the degree of degassing from sub-aerial lavas, are not well constrained. The propensity for an elemental species to be volatilized post-eruption can be described in terms of an emanation coefficient, $\left(E_{\mathrm{x}}\right)$, where $\mathrm{E}_{\mathrm{x}}=\left(\mathrm{C}_{\mathrm{i}}-\mathrm{C}_{\mathrm{f}}\right) / \mathrm{C}_{\mathrm{i}},\left(\mathrm{C}_{\mathrm{i}}=\right.$ concentration of element $\mathrm{x}$ in the magma and $\mathrm{C}_{\mathrm{f}}=$ concentration of element $\mathrm{x}$ in the magma after degassing; Gill et al., 1985; Lambert et al., 1986). The emanation coefficient of Re ranges from 0.12 (Rubin, 1997) to as high as 0.74 ( Norman et al. 2004). The difficulties associated with the analysis of $\mathrm{pg} \mathrm{g}^{-1}$ quantities of Os in basalts make the emanation coefficient of Os even less well known.

In their recent study, Gannoun et al. (2015b) investigated the Re-Os isotope and elemental systematics of basaltic lavas and gas condensates (a range of $\mathrm{Na}-\mathrm{K}-\mathrm{Ca}-\mathrm{Cu}$ sulfates, $\mathrm{Ca}-\mathrm{Mg}-\mathrm{Al}-\mathrm{Fe}$ fluorides, and native sulfur) produced during eruption and degassing at Piton de la Fournaise, Réunion Island, in order to examine the geochemical behavior of these two elements during magma degassing. High temperature $\left(>350{ }^{\circ} \mathrm{C}\right.$ ) deposits were enriched in $\operatorname{Re}\left(24\right.$ to $\left.79 \mathrm{ng} \mathrm{g}^{-1}\right)$, almost two order of magnitude higher than the corresponding lavas $\left(0.2\right.$ to $\left.0.8 \mathrm{ng} \mathrm{g}^{-1}\right)$, while the Os abundances 
of the high temperature condensates were similar to those of the lavas (14 to $132 \mathrm{pg} \mathrm{g}^{-1}$ ). The highest temperature condensates ( $\mathrm{Na}-\mathrm{K}$ sulfates; 384 to $400{ }^{\circ} \mathrm{C}$ ), yielded ${ }^{187} \mathrm{Os} /{ }^{188} \mathrm{Os}$ that were significantly lower (i.e. 0.124-0.129) than their corresponding lava. These unradiogenic osmium isotope ratios were attributed by Gannoun et al. (2015b) to the volatilization of Os originally contained in old, unradiogenic mantle sulfides. Sulfides associated with earlier volcanic eruptions at Réunion Island ( $<7 \mathrm{Ma}$ ) were deemed too young to provide the distinctive unradiogenic Os fingerprint of the volcanic gas, leading Gannoun et al. (2015b) to infer that the observed unradiogenic Os was ultimately derived from a mantle source. In the context of osmium mantle geochemistry, loss of unradiogenic Os during magmas degassing could help to explain osmium isotope disequilibrium between lavas and melting residues.

This contrasted with the Re-Os systematics of the low-to-medium temperature condensates, which contained the highest Os abundances (13 to $\left.77 \mathrm{ng} \mathrm{g}^{-1}\right)$ with unfractionated ${ }^{187} \mathrm{Os} /{ }^{188} \mathrm{Os}(0.130$ to 0.135), which are indistinguishable from the April 2007 lava flow and the historical lavas of Piton de la Fournaise (i.e. ${ }^{187} \mathrm{Os} /{ }^{188} \mathrm{Os}=0.130$ to 0.137 ; Schiano et al., 2012). In addition, very high concentrations of iridium ( 1 to $\left.8 \mathrm{ng} \mathrm{g}^{-1}\right)$ reported for hieratite condensates $\left(\mathrm{K}_{2} \mathrm{SiF}_{6}\right)$ suggested that $\mathrm{Ir}$ was also transported in volatile emissions as gaseous $\operatorname{IrF}_{6}$ (cf. Toutain and Meyer, 1989). The selective enrichment of HSE demonstrates their potential for transport as metallic hexafluorides (Molski and Seppelt 2009; Craciun et al., 2010; Gannoun et al., 2015b; see also review in Day, 2013). The absence of isotopic fractionation between gas deposits and lavas also indicates that external components (such as seawater, rainwater or air), which all possess particularly radiogenic ${ }^{187}$ Os/ $/{ }^{188}$ Os (Levasseur et al., 1998, 1999; Gannoun et al., 2006; Chen et al., 2009) have no significant influence on the Os budget of volcanic gases.

\section{HIGHLY SIDEROPHILE ELEMENT SYSTEMATICS OF ARCS}

Highly siderophile element abundance studies have been applied to arc volcanism to understand both subduction processes and the generation of economic deposits of precious metals within arc settings. A critical question has regarded the potential mobility of the HSE in subduction zone environments and the collateral effects such processes have regarding the siderophile element budget of the mantle. Fractionation of Re and Pt from Os in subduction zone environments could have a potentially significant effect both on Os isotope signatures at arcs (e.g., Brandon et al., 1996), but also on the long-term Re/Os and Pt/Os fractionations observed in OIB, MORB and mantle rocks. In addition, the potential mobility of HSE in subduction zone environments has important 
1560 implications regarding the formation of economic PGE ore deposits such as major epithermal gold 1561 deposits associated with some volcanic arcs (e.g., McInnes et al., 1999). For the purpose of this review, we focus on the petrogenetic implications of arc volcanism.

Arc magmatism includes tholeiitic to calc-alkaline compositions and dominantly involves the generation of basalt-andesites, andesites and more evolved magma-types. Only a limited number of arc volcanoes are known to erupt lavas approaching basaltic or picritic compositions. Because the HSE are typically compatible during mantle melting, as well as during fractional crystallization, this means that Os concentrations in arc volcanic rocks are typically very low, resulting in increased susceptibility of arc lavas to crustal contamination (e.g., Righter et al., 2002; Hart et al., 2002; Lassiter \& Luhr, 2001; Turner et al., 2009; Bezard et al., 2015). High ${ }^{187}$ Os $/{ }^{188}$ Os in arc lavas has therefore been attributed to assimilation of arc crust during magmatic ascent, but also due to enrichment in radiogenic Os due to contamination of the mantle wedge by slab-derived fluids/melts (e.g., Borg et al., 2000; Alves et al., 1999; 2002), or a combination of these processes (Suzuki et al., 2011). In this section, we review the work done so far in arcs, using both lavas, as well as mantlederived xenoliths erupted in association with active arcs. Since the behavior of the HSE are reviewed extensively elsewhere in this volume, the focus of this section is largely on the information that can be obtained from the HSE regarding arc processes.

\section{HSE and ${ }^{187} \mathrm{Os} /{ }^{188} \mathrm{Os}$ in arc lavas}

The majority of arc related volcanism is located around the Pacific 'Ring of Fire', extending from the southern tip of Chile, up much of South and North America, into the Aleutians and Kamchatka, through Japan and down as far as the Tonga Trench and New Zealand. Other significant arcs include the Lesser Antilles Arc and the Scotia Arc (Figure 33). Despite the extensive distribution of arc volcanoes, limited work has been conducted on Re-Os isotopes in arc volcanic rocks, primarily due to the limited availability of high $\mathrm{MgO}$ lavas, which are normally favored for study by Os isotope and HSE abundance studies. High MgO lavas do occur in some arc settings, most notably Grenada, south Lesser Antilles Arc, Tonga, and as boninite occurrences. These lavas are discussed in detail, below.

Work on arcs has shown that arc volcanic rocks typically contain between 0.0001 and $1 \mathrm{ng} \mathrm{g}^{-1}$ Os and 0.01 to $1 \mathrm{ng} \mathrm{g}^{-1} \operatorname{Re}$ (Figure 34). Rhenium concentrations generally increase with decreasing $\mathrm{MgO}$ in arc lavas, consistent with moderate incompatibility of Re. However, Re can also behave as a volatile element during oxidizing conditions in arc lavas, and for this reason it is likely that low concentrations could reflect loss of Re by this process (e.g., Righter et al., 2008). Positive correlation 
between $\mathrm{Os}$ and $\mathrm{MgO}$ is consistent with strong compatibility of Os during fractional crystallization of arc lavas. The low MgO and HSE contents in arc lavas can make them potentially highly susceptible to crustal contamination effects (cf. Lassiter \& Luhr, 2001). Osmium isotopic ratios in recently erupted arc lavas can span an extreme range, from high $\mathrm{MgO}$ lavas with ${ }^{187} \mathrm{Os} /{ }^{188} \mathrm{Os}(\sim 0.127-0.128)$ similar to typical mantle estimates, to andesites, rhyolites and dacites with ${ }^{187} \mathrm{Os} /{ }^{188} \mathrm{Os}>1$. There is an overall relationship of increasing ${ }^{187} \mathrm{Os} /{ }^{188} \mathrm{Os}$ with decreasing Os content, although more than one trend has been recognized in plots of reciprocal Os versus ${ }^{187} \mathrm{Os} /{ }^{188} \mathrm{Os}$ (Figure 35). Alves et al. (2002) pointed out that initial Os isotopic ratios are positively and systematically correlated on ${ }^{187} \mathrm{Os} /{ }^{188} \mathrm{Os}$ versus reciprocal Os plots, reflecting binary mixing processes, with a common endmember represented by upper mantle peridotite compositions.

To date, no study has found clear associations of Re or Os contents and ${ }^{187} \mathrm{Os} /{ }^{188} \mathrm{Os}$ with arc basement type, convergence rate or sediment supply. This may be partly due to the lack of available high $\mathrm{MgO}$ rocks with which to make cross-comparison of 'primary magmatic composition'. For example, Lassen Peak lavas with 8 to $11.1 \mathrm{wt} . \% \mathrm{MgO}$ have up to $0.37 \mathrm{ng} \mathrm{g}^{-1} \mathrm{Os}$ and span a range of ${ }^{187} \mathrm{Os} /{ }^{188} \mathrm{Os}$ from 0.1289-0.235 (Borg et al., 2002). It has been suggested that these lavas contain a contribution of radiogenic Os from the subducting slab. Conversely, Grenada picrites and basalts (10.5-17.4 wt.\% $\mathrm{MgO}$ ) contain up to $0.36 \mathrm{ng} \mathrm{g}^{-1}$ Os and have a slightly more restricted range of ${ }^{187} \mathrm{Os} /{ }^{188} \mathrm{Os}(0.1268-0.1644)$, yet these lavas are not considered to have a contribution from the slab, but instead have experienced various levels of crustal assimilation (Woodland et al., 2002; Bezard et al., 2015). Likewise, boninite (13 wt. \%) and some low $\mathrm{MgO}$ lavas ( $<1.5$ wt. \%) from the TongaKermadec arc have ${ }^{187} \mathrm{Os} /{ }^{188} \mathrm{Os}$ of $0.1275-0.1283$, indicating that more radiogenic values for lavas in this arc are consistent with localized arc contamination (Turner et al., 2009). Unique to that study is that the sample with the least radiogenic Os signature is a dacite, suggesting that evolved magmas can develop by fractionation from mantle-derived magma with minimal interaction with high Re/Os arc crust. High $\mathrm{MgO}$ ( $\geq 10 \mathrm{wt} . \%$ ) volcanics from the central and northern Tonga arc, including some with boninitic affinity, possess a greater range of ${ }^{187} \mathrm{Os} /{ }^{188} \mathrm{Os}$ from $0.131-0.156$, while lower $\mathrm{MgO}$ samples range up to ${ }^{187} \mathrm{Os} /{ }^{188} \mathrm{Os}=0.4$, again largely illustrating the potential effects of localized arc contamination (Dale et al., 2012b).

Contents of the HSE in arc-related lavas have been reported for Grenada basalts and picrites, Izu-Bonin lavas (Woodland et al., 2002) and Lihir lavas (McInnes et al., 1999) (Figure 36). These generally high MgO lavas show similar Re and PPGE enrichment over the IPGE, to many intraplate tholeiites and alkali basalts (e.g., Day, 2013). However, despite the picritic ( $\mathrm{MgO}>13.5$ wt. \%) nature of Grenada lavas, they contain low concentrations of the HSE $\left(<0 \cdot 2 \mathrm{ng} \mathrm{g}^{-1} \mathrm{Ir}, 1-4 \mathrm{ng} \mathrm{g}^{-1} \mathrm{Pd}\right)$ compared with other lavas of similar MgO content. Woodland et al. (2002) argued that this was 
probably due to a combination of lower degrees of partial mantle melting and early removal of PGE with cumulus phases such as olivine, magnetite and sulfide. Comparison of alkali Grenada lavas with boninitic Izu-Bonin lavas illustrates that although the major element chemistries of Grenada and IzuBonin are different, relative and absolute abundances of the IPGE and PPGE are similar. Rhenium, however, is markedly depleted in the Grenada picrites compared with the Izu-Bonin boninites, suggesting either retention of Re by residual garnet in the Grenada sub-arc mantle wedge (Woodland et al., 2002) or volatile-loss of Re. In some of these cases, their generation above a subduction zone did not appear to have any significant systematic effect on the HSE signatures of resultant lavas. However, Grenada samples possess markedly high $\mathrm{Pt} / \mathrm{Ru}$ ratios and significant PPGE/IPGE fractionation in general. This feature has also been observed in Tongan arc lavas and associated lavas from the Fonualei rifts (Dale et al. 2012b), which possess amongst the most extreme Pt/Ru ratios yet observed in terrestrial mantle-derived magmas (up to 300 in rocks with $\mathrm{MgO}>8$ wt. \%). This was attributed by Dale et al. (2012b) to the retention of IPGE in the mantle source by chromitite and/or IPGE-rich PGM, despite sulfide exhaustion. Sulfide exhaustion is consistent with the sulfideundersaturated nature of the magmas and led to very high PPGE concentrations in the melts.

\section{HSE and ${ }^{187} \mathrm{Os} /{ }^{188} \mathrm{Os}$ in arc xenoliths}

HSE studies of mantle xenoliths from arc settings have provided the opportunity to document the behavior of these HSE during slab fluid-induced metasomatism of the mantle wedge, with spinel harzburgite, websterite and pyroxenite mantle xenoliths occuring in back-arc environments in a number of arcs. Relatively radiogenic Os isotope signatures in mantle xenoliths and mantle rocks from arc settings, including the Cascades, Canadian Cordillera, Japan, Lihir, Papua New Guinea, Kamchatka, and the Catalina Schist have been documented, and attributed to the mobility of Os in slab fluids (Brandon et al., 1996; 1999; McInnes et al., 1999; Peslier et al., 2000; Widom et al., 2003). For example Simcoe xenoliths, which represent fragments of mantle lithosphere from the back-arc of the Cascade arc front, have been metasomatised by silica-rich fluids or hydrous melts leading to higher $\mathrm{fO}_{2}$ leading to radiogenic Os isotopic compositions being imparted to these peridotites (Brandon et al., 1996; 1999). These features are consistent with part or the entire metasomatic agent being derived from the Juan de Fuca slab. Studies of Kamchatka peridotites also indicate metasomatism of the Kamchatka sub-arc mantle wedge by radiogenic slab-derived fluids and melts (Widom et al., 2003).

HSE patterns of the arc-related mantle xenoliths are broadly similar to typical oceanic mantle xenoliths (Figure 36), but the xenoliths can often exhibit elevated ${ }^{187} \mathrm{Os} /{ }^{188} \mathrm{Os}$, with Simcoe xenoliths 
ranging from 0.123-0.157 and Kamchatka xenoliths ranging from 0.123-0.148. The regional variations in $\mathrm{Re}-\mathrm{Os}$ isotope signatures are consistent with previous petrographic and geochemical studies of the Kamchatka mantle xenoliths that reveal multistage metasomatic histories resulting from interaction of the mantle wedge with a variety of slab-derived fluids and melts, including silicic slab-melt metasomatism associated with subduction of relatively hot, young $(\sim 15-25 \mathrm{Ma})$ oceanic crust in the northern arc front, hydrous slab-fluid metasomatism associated with subduction of colder, old ( 100 Ma) oceanic crust in the southern arc front, and carbonate-rich slab-melt metasomatism in the southern segment behind the arc front, where the slab is deeper. Similar ranges of Re-Os isotope signatures in peridotites from Avachinsky, Japan and Lihir, and from Valovayam and the Cascades, respectively, suggest that the age (temperature) and depth of subducting oceanic crust influences the Re-Os composition of metasomatized sub-arc mantle.

\section{Radiogenic Os from slab components or from crustal contamination}

A continuing debate exists over the influence of slab-derived ${ }^{187} \mathrm{Os} /{ }^{188} \mathrm{Os}$ to arcs, versus the potential for crustal or seawater contamination of magmas with low Os abundances. From Lassen lavas, Borg et al. (2000) showed that crustal contamination could only explain the Re-Os isotope systematics if distribution coefficients for Re in sulfide were $~ 40-1100$ times higher than published estimates, and instead argued for contributions from a highly radiogenic Os slab component $\left({ }^{187} \mathrm{Os} /{ }^{188} \mathrm{Os}\right.$ up to 1.4$)$. Alves et al. (2002) also favoured slab components adding radiogenic Os to arcs, citing evidence from arcs worldwide for different mixing systematics between mantle peridotite and variably radiogenic Os slab contributions. Conversely, Bezard et al. (2015) have shown that Grenada picrites with radiogenic ${ }^{87} \mathrm{Sr} /{ }^{86} \mathrm{Sr}(0.705)$ have ${ }^{187} \mathrm{Os} /{ }^{188} \mathrm{Os}(0.127)$ that overlap with the mantle range and that assimilation and fractional crystallization can explain compositions of Lesser Antilles lavas, without the requirement of a slab input (Figure 37). Dreher et al. (2005) studied Os isotopes in Mindanao adakites, showing that the majority of these rocks had unradiogenic Os isotopes, inconsistent with the idea that adakites with high $\mathrm{Sr} / \mathrm{Y}$ and low $\mathrm{Y}$ and heavy rare earth element concentrations, reflect melting of young subducted crust in subduction zones.

On the other hand, the range in Os isotopes in Mexican Volcanic Belt rocks, which represent subduction-related calc-alkaline and lamprophyric rocks in which high $\mathrm{fO}_{2}$ precludes sulfide fractionation, could be explained up to $12 \%$ assimilation and fractional crystallization (Lassiter \&

1693 Luhr, 2001). To obviate potential issues of shallow-level crustal contamination, Suzuki et al. (2011) 1694 examined Cr-spinel from beach sands in the Bonin Islands, reasoning that $\mathrm{Cr}$-spinel is an early1695 formed mineral in most magmas and an indicator of primitive magma Os compositions. They found 
unradiogenic Os in Cr-spinel with boninitic affinity, versus a potential slab component reflected in spinel with tholeiitic affinity. These authors also argued that oxidative conditions in the mantle can lead to radiogenic Os mobilization in the arc. Ultimately, the most convincing arguments for or against radiogenic Os from the slab comes from high-MgO Grenada picrites. These samples have been shown to have less-radiogenic Os signatures in more mafic lavas, with an increasing influence of crustal contamination in more evolved melts (Woodland et al., 2002; Bezard et al., 2015). Combined with evidence for the potential influence of subduction zone fluids on the composition of arc xenoliths, these results suggest that some contribution from the slab can be exhibited in arc lavas, but that the role of crustal contamination of melts within the arc itself can obfuscate original mantlederived signatures.

\section{Mechanical mixing processes}

The debate as to whether slab-derived signatures are evident in HSE and Os isotopes within arc volcanic rocks has recently been enhanced by the recognition that mechanical mixing between peridotite mantle and recycled ocean rocks is likely an important process in modifying HSE contents at subduction zones. Studies of HSE contents and Os isotope compositions of mélange mafic metamorphic blocks at Catalina Island and the Franciscan Complex (California) and at the Samana Metamorphic Complex (Dominican Republic) have shown significant differences between block cores and block rims (Penniston-Dorland et al., 2012; 2014). In particular, while the cores of the blocks have enhanced PPGE compared with IPGE and radiogenic ${ }^{187} \mathrm{Os} /{ }^{188} \mathrm{Os}$, mimicking patterns for evolved basaltic rocks, or some sedimentary protoliths, the rims approach HSE contents expected in some mantle peridotites, with less radiogenic ${ }^{187} \mathrm{Os} /{ }^{188} \mathrm{Os}$ (Figure 38). Penniston-Dorland et al. (2014) have demonstrated that mèlange mechanical mixing occurs across a range of temperatures ( $\leq 200^{\circ} \mathrm{C}$ to $\sim 600^{\circ} \mathrm{C}$ ) during subduction leading to a hybrid rock composition of peridotite, basaltic materials and sediments. Measurements of the HSE in arc volcanics suggest variable amounts of peridotitic mantle with radiogenic Os components (e.g., Alves et al., 1999; 2002; Borg et al., 2000) and mechanical mixing may play a major role in this process. 
The highly siderophile elements are expected to be strongly incorporated into Earth's metallic core, but their abundance in the upper mantle appears to have been set by the late addition of meteoritic material after core formation was complete. Partial melting of the mantle since that time has resulted in a significant fractionation of the HSE. The platinum-PGE, Re and Au, can behave as moderately compatible or incompatible elements during melting, and may be variably enriched in melts, whereas the iridium-PGE behave as highly compatible elements. Sulfide is a major host for HSE in mantle rocks, despite its relatively low abundance (between 0.04 and $0.08 \%$ ). However, sulfide cannot account for the fractionation of HSE that occurs during the melting that generates MORB, which generally possess very low Os-Ir-Ru contents, and relatively high Re-Pd and Pt. Rather this fractionation appears to result from the crystallisation of Os-Ir-Ru alloy phases in refractory mantle rocks, accompanying the exhaustion of sulfide by melting. The HSE content of MORB is further modified by the segregation of sulfide during fractional crystallisation in the magmatic environment, where the HSE are quantitatively removed into sulfide, leaving the residual melt depleted in these elements.

The fractionation of Re and Os accompanying the generation of MORB, intraplate lavas and those produced at convergent margins is one of the key processes controlling the distribution of these elements between Earth's mantle and crust. Therefore, decay of ${ }^{187} \mathrm{Re}$ to ${ }^{187} \mathrm{Os}$ provides a potentially exceptional tracer of recycled crustal materials in Earth's mantle. This is because both oceanic and continental crust possess high Re/Os ratios, and develop radiogenic Os isotope compositions over time, which in turn can be readily traced as recycled material if mixed back into the convective mantle. However, while MORB glass commonly preserves a radiogenic ${ }^{187} \mathrm{Os} /{ }^{188} \mathrm{Os}$ isotope composition, this is most readily explained by seawater-derived contamination of the melt that occurs during magma ascent through the oceanic crust. Although reliable data for MORB glass remain

1754 limited these observations suggest that to a greater or lesser extent all MORB glass has been affected 1755 by seawater-derived contamination. This then also implies that other elements may have been 1756 affected by such contamination, most likely dependent upon their relative concentration in MORB 1757 glass and seawater. Sulfide, although demonstrably affected by the same seawater contamination, 1758 provides a more reliable record of the primary ${ }^{187} \mathrm{Os} /{ }^{188} \mathrm{Os}$ isotope composition of MORB, particularly those sulfides with high Os concentrations (i.e. > $100 \mathrm{ng} \mathrm{g}^{-1}$ ). These high-Os sulfides preserve relatively unradiogenic ${ }^{187} \mathrm{Os} /{ }^{188} \mathrm{Os}$ isotope compositions pointing to a mantle source that 
1761 has experienced long term depletion of Re, similar to abyssal peridotites, with no evidence for the 1762 presence of recycled crust.

In addition to the effects of seawater contamination observed in MORB, intraplate lavas and 1764 those generated at convergent margins may interact with sub-continental lithospheric mantle, itself

1765 variably contaminated by multiple metasomatic events since it became isolated from the convecting 1766 mantle, and incorporate additional complications from the overlying crust. At convergent margins 1767 there is the additional complication of fluxes generated as a result of the subduction of the down1768 going slab with the potential for overprinting pre-existing Re-Os isotope and HSE fingerprints. While 1769 the HSE and its isotope systems offer some unique perspecives on mantle processes and the 1770 generation of a wide range of magmas, their application needs to be exercised with care - the geochemical context provided by other isotope systems and trace element signatures should be considered and the specific set of local conditions, both physical and chemical, taken into account in addition to the use of these invaluable tools.

\section{ACKNOWLEDGMENTS}

We thank Jean-Louis Birck, Olivier Alard, Christian Pin, Ivan Vlastélic, Anthony Cohen, Ali Bouhifd for valuable insight and discussions over the years. AG would like to thank Jean-Luc Devidal for assistance with the electron microprobe measurements at Blaise Pascal University. The authors wish to thank Chris W. Dale for review that greatly improved the manuscript. This research was partially financed by the French Government Laboratory of Excellence initiative ${ }^{\circ}$ ANR-10LABX-0006, the Région Auvergne and the European Regional Development Fund. This is Laboratory of Excellence ClerVolc contribution number 178. 
Agranier A et al. (2005) The spectra of isotopic heterogeneities along the Mid-Atlantic Ridge. Earth Planet Sci Lett 238:96-109

Ahmed AH and Arai S (2002) Unexpectedly high-PGE chromitite from the deeper mantle section of the northern Oman ophiolite and its tectonic implications. Contrib Mineral Petrol 143:263-278

Ahmed AH, Hanghoj K, Kelemen PB, Hart SR and Arai S (2006) Osmium isotope systematics of the Proterozoic and Phanerozoic ophiolite chromites: In situ ion probe analysis of primary Or-rich PGM. Earth Planet Sci Lett 245:777-791

Alard O, Griffin WL, Lorand JP, Jackson SE, O'Reilly SY (2000) Non-chondritic distribution of the highly siderophile elements in mantle sulfides. Nature 407:891-894

Alard O, Griffin WL, Pearson NJ, Lorand J-P, O'Reilly SY (2002) New insights into the Re-Os systematics of subcontinental lithospheric mantle from in-situ analysis of sulfides. Earth Planet Sci Lett 203:651-663

Alard O, Luguet A, Pearson NJ, Griffin WL, Lorand JP, Gannoun A, Burton KW, O'Reilly SY (2005) In situ Os isotopes in abyssal peridotites bridge the isotopic gap between MORBs and their source mantle. Nature 436:1005-1008

Allègre CJ, Turcotte DL (1986) Implications of a two-component marble-caked mantle. Nature 323:123-127

Alves S, Schiano P, Allègre CJ (1999) Rhenium-osmium isotopic investigation of Java subduction zone lavas. Earth Planet Sci Lett 168:65-77

Alves S, Schiano P, Capmas F, Allègre CJ (2002) Osmium isotope binary mixing arrays in arc volcanism. Earth Planet Sci Lett 198:355-369

Anbar AD, Creaser CR, Papanastassiou DA, Wasserburg GJ (1992) Rhenium in seawater: Confirmation of generally conservative behaviour. Geochim Cosmochim Acta 56:4099-4103

Andrews DA, Brenan JM (2002a) The solubility of ruthenium in sulfide liquid: Implications for platinum-group mineral (PGM) stability and sulfide melt/silicate melt partitioning. Chem Geol 192:163-181

Andrews DA, Brenan JM (2002b) Phase Equilibrium Constraints on the Magmatic Origin of Laurite + Ru-Os-Ir Alloy. Can Mineral 40:1705-1716

Anguita F, Hernan F (1975) A propagating fracture model versus a hot spot origin for the Canary Islands. Earth Planet Sci Lett 27:11-19

Araujo AJN, Carlson RW, Gaspar JC, Bizzi LA (2001) Petrology of kamfugites and kimberlites from the Alto Paranaiba alkaline province, Minas Gerais, Brazil. Contrib Mineral Petrol 142:163-177

Argus DF, Gordon RG, DeMets C (2011) Geologically current motion of 56 plates relative to the nonet-rotation reference frame. Geochem Geophys Geosyst 12. http://dx.doi.org/10.1029/2011GC003751

Arndt NT (2012) Plates vs. Plumes: a Geological Controversy (2010) Wiley-Blackwell, Chichester, $\mathrm{UK}, 364 \mathrm{p}$

Arndt N, Christensen U (1992) The role of lithospheric mantle in continental flood volcanism; thermal and geochemical constraints. J Geophys Res 97:10967-10981

Arndt NT, Czamanske GK, Wooden JL, Fedorenko VA (1993) Mantle and crustal contributions to continental flood volcanism. Tectonophysics 223:39-52

Augé T (1985) Platinum-group-mineral inclusions in ophiolitic chromitite from the Vourinos Complex, Greece. Can Mineral 23:163-171

Augé T (1988) Platinum-group minerals in the Tiebaghi and Vourinos ophiolitic complexes: genetic implications. Can Mineral 26:177-192

Bach W, Peucker-Ehrenbrink B, Hart SR and Blusztajn JS (2003) Geochemistry of hydrothermally altered oceanic crust: DSDP/ODP Hole 504B-Implications for sea water-crust exchange 
budgets and $\mathrm{Sr}-$ and $\mathrm{Pb}$-isotopic evolution of the mantle. Geochem Geophys Geosyst 3 . http://dx.doi.org/10.1029/2002GC000419

Baker JA, Jensen KK (2004) Coupled 186Os-187Os enrichments in the Earth's mantle - coremantle interaction or recycling of ferromanganese crusts and nodules? Earth Planet Sci Lett 220:277-286

Ballhaus C, Bockrath C, Wohlgemuth-Ueberwasser C, Laurenz V, Berndt J (2006) Fractionation of the noble metals by physical processes. Contrib Mineral Petrol 152:667-684

Barfod, DN (1999) Noble Gas Geochemistry of the Cameroon Line Volcanic Chain. (PhD thesis). Michigan Univ

Barnes SJ, Fiorentini ML (2008) Iridium, ruthenium and rhodium in komatiites: evidence for iridium alloy saturation. Chem Geol 257:44-58

Barnes S-J, Naldrett AJ, Gorton MP (1985) The origin of the fractionation of platinum-group elements in terrestrial magmas. Chemical Geology 53:302-323

Bebout GE, Ryan JG, Leeman WP (1993) B-Be systematics in subduction-related metamorphic rocks: Characterization of the subducted component. Geochim Cosmochim Acta 57:2227-2237

Becker H (2000) Re-Os fractionation in eclogites and blueschists and the implications for recycling of oceanic crust into the mantle. Earth Planet Sci Lett 177:287-300

Becker H, Jochum KP, Carlson RW (2000) Trace element fractionation during dehydration of eclogites from high-pressure terranes and the implications for element fluxes in subduction zones. Chem Geol 163:65-99

Becker H, Horan MF, Walker RJ, Gao S, Lorand JP, Rudnick RL (2006) Highly siderophile element composition of the Earth's primitive upper mantle: constraints from new data on peridotite massifs and xenoliths. Geochim Cosmochim Acta 70:4528-4550

Becker H, Dale CW (2015) Re-Pt-Os isotopic and highly siderophile element behavior in oceanic and continental mantle tectonites. Rev Mineral Geochem 81 xxxxxx

Bennett VC, Norman MD, Garcia MO (2000) Rhenium and platinum group element abundances correlated with mantle source components in Hawaiian picrites: sulfides in the plume. Earth Planet Sci Lett 183:513-526

Bezard R, Schaefer BF, Turner S, Davidson JP, Selby D (2015) Lower crustal assimilation in oceanic arcs: insights from an osmium isotopic study of the Lesser Antilles. Geochim Cosmochim Acta 150:330-344

Bezos A et al. (2005) Platinum-group element systematics in Mid-Oceanic Ridge basaltic glasses from the Pacific, Atlantic, and Indian Oceans. Geochim Cosmochim Acta 69:2613-2627

Birck JL (2001) The precision and sensitivity of Thermal Ionisation Mass Spectrometry (TIMS): an overview of the present status. Geostand Geoanal Res 25:253-259

Birck JL, Roy Barman M, Capmas F (1997) Re-Os isotopic measurements at the femtomole level in natural samples. Geostandards Newsletter 20:9-27

Bird JM, Weathers MS (1975) Josephinite: specimens from the Earth's core?. Earth Planet Sci Lett 28:51-64

Bird JM, Bassett WA (1980) Evidence of a deep mantle history in terrestrial osmium-iridiumruthenium alloys. J Geophys Res 85:5461-5470

Bird JM, Meibomb A, Frei R, Nägler TF (1999) Osmium and lead isotopes of rare OsIrRu minerals: derivation from the core-mantle boundary region?. Earth Planet Sci Lett 170:83-92

Blusztajn J, Hart SR, Ravizza G and Dick HJB (2000) Platinum-group elements and Os isotopic characteristics of the lower oceanic crust. Chem Geol 168:113-122

Bockrath C, Ballhaus C, Holzheid A (2004a) Fractionation of the platinum-group elements during mantle melting. Science 305:1951-1953

Bockrath C, Ballhaus C, Holzheid A (2004b) Stabilities of laurite RuS2 and monosulfide liquid solution at magmatic temperature. Chem Geol 208:265-271 
Boivin P, Bachélery P (2009) Petrology of 1977 to 1998 eruptions of Piton de la Fournaise, La Réunion Island. J Volcanol Geotherm Res 184:109-105

Borg LE, Brandon AD, Clynne MA, Walker RJ (2000) Re-Os isotopic systematics of primitive lavas from the Lassen region of the Cascade arc, California. Earth Planet Sci Lett 177:301-317

Borisov A, Jones JH (1999) An evaluation of Re, as an alternative to Pt, for the 1 bar loop technique: an experimental study at $1400^{\circ} \mathrm{C}$. Am Mineral 84:1528-1534

Borisov A, Palme H, Spettel B (1994) Solubility of palladium in silicate melts: implications for core formation in the Earth. Geochim Cosmochim Acta 58:705-716

Borisov A, Palme H (1995) The solubility of iridium in silicate melts: new data from experiments with $\operatorname{Ir}_{10} \mathrm{Pt}_{90}$ alloys. Geochim Cosmochim Acta 59:481-485

Borisov A, Palme H (1997) Experimental determination of the solubility of platinum in silicate melts. Geochim Cosmochim Acta 61:4349-4357

Borisov A, Palme H (2000) Solubilities of noble metals in Fe containing silicate melts as derived from experiments in Fe-free systems. Am Mineral 85:1665-1673

Botcharnikov RE, Holtz F, Mungall JE, Beermann O, Linnen RL, Garbe-Schoenberg D (2013) Behavior of gold in a magma at sulfide-sulfate transition: Revisited. Amer Mineral 98:14591464

Brandl PA, Beier C, Regelous M, Abouchami W, Haase KM, Garbe-Schönberg D, Galer SJG (2012) Volcanism on the flanks of the East Pacific Rise: Quantitative constraints on mantle heterogeneity and melting processes. Chem Geol 298-299:41-56

Brandon AD, Creaser RA, Shirey SB, Carlson RW (1996) Osmium recycling in subduction zones. Science 272:861-864

Brandon AD, Graham DW, Waight T, Gautason B (2007) ${ }^{186}$ Os and ${ }^{187}$ Os enrichments and high$3 \mathrm{He} / 4 \mathrm{He}$ sources in the Earth's mantle: evidence from Icelandic picrites. Geochim Cosmochim Acta 71:4570-4591

Brandon AD, Norman MD, Walker RJ, Morgan JW (1999) ${ }^{186}$ Os- ${ }^{187}$ Os systematics of Hawaiian picrites. Earth Planet Sci Lett 174: 25-42

Brandon AD, Snow JE, Walker RJ, Morgan JW, Mock TD (2000) ${ }^{190} \mathrm{Pt}^{186}$ Os and ${ }^{187} \mathrm{Re}^{187} \mathrm{Os}$ systematics of abyssal peridotites. Earth Planet Sci Lett 177:319-355

Brandon AD, Puchtel IS, Walker RJ, Day JMD, Irving AJ, Taylor LA (2012) Evolution of the martian mantle inferred from the ${ }^{187} \mathrm{Re}-{ }^{187} \mathrm{Os}$ isotope and highly siderophile element abundance systematics of shergottite meteorites. Geochim Cosmochim Acta 76:206-235

Brandon AD, Walker RJ, Morgan JW, Norman MD, Prichard HM (1998) Coupled ${ }^{186}$ Os and ${ }^{187}$ Os evidence for core-mantle interaction. Science 280:1570-1573

Brandon AD, Walker RJ, Puchtel IS, Becker H, Humayun N, Revillon S (2003) ${ }^{186}$ Os- ${ }^{187}$ Os systematics of Gorgona Island komatiites: implications for early growth of the inner core. Earth Planet Sci Lett 206:411-426

Brandon AD, Walker RJ, Puchtel IS (2006) Platinum-osmium isotope evolution of the Earth's mantle: constraints from chondrites and Os-rich alloys. Geochim Cosmochim Acta 70:20932103

Brenan JM (2008) Re-Os fractionation by sulfide-silicate partitioning: a new spin. Chem Geol 248:140-165

Brenan JM, Andrews D (2001) High Temperature Stability of Laurite and Ru-Os-Ir Alloy and their Role in PGE Fractionation in Mafic Magmas. Can Mineral 39:573-592

Brenan JM, Cherniak DJ, Rose LA (2000) Diffusion of osmium in pyrrhotite and pyrite: implications for closure of the Re-Os isotopic system. Earth Planet Sci Lett 188:399-413

Brenan JM, McDonough WF, Dalpé C (2003) Experimental constraints on the partitioning of rhenium and some platinum-group elements between olivine and silicate melt. Earth Planet Sci Lett 212:135-150 
Brenan JM, McDonough WF, Ash R (2005) An experimental study of the solubility and partitioning of iridium, osmium and gold between olivine and silicate melt. Earth Planet Sci Lett 237:855872

Brenan JM and McDonough WF (2009) Core formation and metal-silicate fractionation of osmium and iridium from gold. Nat Geosci 2:798-801

Brenan JM, Finnegan CF, McDonough WF (2012) Experimental constraints on the partitioning of $\mathrm{Ru}, \mathrm{Rh}, \mathrm{Ir}, \mathrm{Pt}$ and Pd between chromite and silicate melt: the importance of ferric iron. Chem Geol 302-303:16-32

Brenan JM, Bennett N, Zajacz Z (2015) Fractionation of the highly siderophile elements (HSE) during planetary differentiation: An overview of results from experiments done at high pressure and temperature. Rev Mineral Geochem 81:1-74

Brügmann GE, Arndt NT, Hofmann AW, Tobschall HJ (1987) Noble metal abundances in komatite suites from Alexo, Ontario and Gorgona Island, Columbia. Geochim Cosmochim Acta 51:2159-2169

Burton KW, Schiano P, Birck JL, Allègre CJ (1999) Osmium isotope disequilibrium between mantle minerals in a spinel-lherzolite. Earth Planet Sci Lett 172:311-322

Burton KW, Schiano P, Birck JL, Allègre CJ, Rehkamper M, Halliday AN, Dawson JB (2000) The distribution and behaviour of rhenium and osmium amongst mantle minerals and the age of the lithospheric mantle beneath Tanzania. Earth Planet Sci Lett 183:93-106

Burton KW, Gannoun A, Birck JL, Allègre CJ, Schiano P, Clocchiatti R, Alard O (2002) The compatibility of rhenium and osmium in natural olivine and their behaviour during mantle melting and basalt genesis. Earth Planet Sci Lett 198:63-76

Burton KW, Gannoun A, Parkinson, IJ, Schiano, P (2015) No evidence for radiogenic osmium in the source of mid-ocean ridge basalts from the Indian Ocean. Submitted to Geochim Cosmochim Acta

Capobianco CJ, Drake MJ (1990) Partitioning of ruthenium, rhodium, and palladium between spinel and silicate melt and implications for platinum-group element fractionation trends. Geochim Cosmochim Acta 54:869-874

Capobianco CJ, Hervig RL, Drake MJ (1994) Experiments on crystal/liquid partitioning of $\mathrm{Ru}, \mathrm{Rh}$ and Pd for magnetite and hematite solid solutions crystallized from silicate melt. Chem Geol 113:23-43

Carlson RW (2005) Application of the Pt-Re-Os isotopic systems to mantle geochemistry and geochronology. Lithos 82:249-272

Carlson RW, Nowell GM (2001) Olivine-poor sources for mantle-derived magmas: Os and Hf isotopic evidence from potassic magmas of the Colorado plateau. Geochem Geophys Geosys 2 (2000GC000128)

Carlson RW, Esperance S, Svisero DP (1996) Chemical and Os isotopic study of Cretaceous potassic rocks from southern Brazil. Contrib Mineral Petrol 125:393-405

Cebria JM, Lopez-Ruiz J, Doblas M, Martins LT, Munha J (2003) Geochemistry of the Early Jurassic Messejana-Plasencia dyke (Portugal-Spain); implications on the origin of the Central Atlantic Magmatic Province. J Petrol 44:547-568

Chalapathi Rao NV, Creaser RA, Lehmann B, Panwar BK (2013) Re-Os isotope study of Indian kimberlites and lamproites: implications for mantle source regions and cratonic evolution. Chem Geol 353:36-47

Chaussidon M, Jambon A (1994) Boron content and isotopic composition of oceanic basalts: geochemical and cosmochemical implications. Earth Planet Sci Lett 121:277-291

Chaussidon M, Marty B (1995) Primitive isotope composition of the mantle. Science 269:383-386

Chatterjee R, Lassiter JC (2015) High precision Os isotopic measurement using N-TIMS: Quantification of various sources of error in ${ }^{186} \mathrm{Os} /{ }^{188}$ Os measurements. Chem Geol 396:112123 
Chazey WJ, Neal CR (2005) Platinum-group element constraints on source composition and magma evolution of the Kerguelen Plateau using basalts from ODP Leg 183. Geochim Cosmochim Acta 19:4685-4701

Chen C, Sedwick PN, Sharma M (2009) Anthropogenic osmium in rain and snow reveals globalscale atmospheric contamination. P Nat Acad Sci USA 106:7724-7728

Chesley JT, Ruiz J (1998) Crust-mantle interaction in large igneous provinces: implications from ReOs isotope systematics of the Columbia River flood basalts. Earth Planet Sci Lett 154:1-11

Chesley J, Ruiz J, Righter K, Ferrari L, Gomez-Tuena A (2002) Source contamination versus assimilation: an example from the Trans-Mexican Volcanic Arc. Earth Planet Sci Lett 195:211221

Chou CL (1978) Fractionation of siderophile elements in the Earth's upper mantle. Proc Lunar Planet Sci Conf. 9:219-230

Chu ZY, Harvey J, Liu CZ, Guo JH, Wu FY, Tian W, Zhang YL, Yang YH (2013) Source of highly potassic basalts in northeast China: evidence from Re-Os, Sr-Nd-Hf isotopes and PGE geochemistry. Chem Geol 357:52-66

Class C, Goldstein SL, Shirey SB (2009) Osmium isotopes in Grand Comore lavas: A new extreme among a spectrum of EM-type mantle endmembers. Earth Planet Sci Lett 284:219-227

Clocchiatti R (1977) Les inclusions vitreuses des phenocristaux d'olivine et de chromite d'un 'basalte picritique' de la ride medio-atlantique: témoins de la contamination mécanique d'un basalte a olivine. C R Acad Sci Paris 285:1155-1158

Colodner D, Sachs J, Ravizza G, Turekian K, Edmond J, Boyle E (1993) The geochemical cycle of rhenium: a reconnaissance. Earth Planet Sci Lett 117:205-221

Coltice N, Bertrand H, Rey P, Jourdan F, Philipps BR, Ricard Y (2009). Global warming of the mantle beneath continents back to the Archean. Gondwana Res 15:254-266

Condomines M, Morand $\mathrm{P}$, Allègre CJ $(1981){ }^{230} \mathrm{Th}-{ }^{238} \mathrm{U}$ radioactive disequilibria in tholeiites from the Famous zone (Mid Atlantic Ridge, 36 $50^{\prime} \mathrm{N}$ : Th and Sr isotopic geochemistry. Earth Planet Sci Lett 121:247-256

Connolly BD, Puchtel IS, Walker RJ, Arevalo R, Piccoli PM, Byerly G, Robin-Popieul C, Arndt N (2011) Highly siderophile element systematics of the $3.3 \mathrm{Ga}$ Weltevreden komatiites, South Africa: implications for early Earth history. Earth Planet Sci Lett 311:253-263

Conticelli S, Carlson RW, Widom E, Serri G (2007) Chemical and isotopic composition (Os, Pb, Nd, and $\mathrm{Sr}$ ) of Neogene to Quaternary calc-alkalic, shoshonitic, and ultrapotassic mafic rocks from the Italian peninsula: inferences on the nature of their mantle sources. Geol Soc Am Special Paper 418:171-202

Coogan LA (2014) The lower oceanic crust. In Treatise on Geochemistry (eds. K. Turekian and H. D. Holland). Elsevier, pp. 497-541

Cottrell E, Walker D (2006) Constraints on core formation from Pt partitioning in mafic silicate liquids at high temperatures. Geochim Cosmochim Acta 70:1565-1580

Courtillot V, Jaupart C, Manighetti I, Tapponnier P, Besse J (1999) On causal links between flood basalts and continental breakup. Earth Planet Sci Lett 166:177-195

Courtillot V, Davaille A, Besse J, Stock J (2003) Three distinct types of hotspots in the Earth's mantle. Earth Planet Sci Lett 205:295-308

Craciun R, Picone D, Long RT, Li S, Dixon DA (2010) Third row transition metal hexafluorides, extraordinary oxidizers, and Lewis acids: electron affinities, fluoride affinities, and heats of formation of $\mathrm{WF}_{6}, \mathrm{ReF}_{6}, \mathrm{OsF}_{6}, \mathrm{IrF}_{6}, \mathrm{PtF}_{6}$, and $\mathrm{AuF}_{6}$. Inorg Chem 49:1056-1070

Crank J (1975) The Mathematics of Diffusion. Oxford University Press, New York

Creaser RA, Papanastassiou DA, Wasserburg GJ (1991) Negative thermal ion mass spectrometry of osmium, rhenium, and iridium. Geochim Cosmochim Acta 55:397-401

Crocket JH (2000) PGE in fresh basalt, hydrothermal alteration products, and volcanic incrustations of Kilauea volcano, Hawaii. Geochim Cosmochim Acta 64:1791-1807 
Crocket JH (2002) Platinum-group elements in basalts from Maui, Hawai'i: low abundances in alkali basalts. Can Mineral 40:595-609

Crockett JH, Fleet ME, Stone WE (1997) Implications of composition for experimental partitioning of platinum-group elements and gold between sulfide liquid and basalt melt: The significance of nickel content. Geochim Cosmochim Acta 61:4139-4149

Czamanske GK, Moore JG (1977) Composition and phase chemistry of sulfide globules in basalt in the Mid-Atlantic Ridge rift valley near $37^{\circ} \mathrm{N}$ lat. Geol Soc Am Bull 88:587-599

Dale CW, Gannoun A, Burton KW, Argles TW, Parkinson IJ (2007) Rhenium-osmium isotope and elemental behaviour during subduction of oceanic crust and the implications for mantle recycling. Earth Planet Sci Lett 177:211-225

Dale CW, Burton KW, Pearson DG, Gannoun A, Alard O, Argles TW, Parkinson IJ (2009a) Highly siderophile element behaviour accompanying subduction of oceanic crust: whole rock and mineral-scale insights from a high-pressure terrain. Geochim Cosmochim Acta 73:1394-1416

Dale CW, Pearson DG, Starkey NA, Stuart FM, Ellam RM, Larsen LM, Fitton JG, Macpherson CG (2009b) Osmium isotopes in Baffin Island and West Greenland picrites: implications for the $187 \mathrm{Os} / 188 \mathrm{Os}$ composition of the convecting mantle and the nature of the high $3 \mathrm{He} / 4 \mathrm{He}$ mantle. Earth Planet Sci Lett 278:267-277

Dale CW, Burton KW, Greenwood RC, Gannoun A, Wade J, Wood BJ, Pearson DG (2012a) Late accretion on the earliest planetesimals revealed by the highly siderophile elements. Science 336:72-75

Dale CW, Macpherson CG, Pearson DG, Hammond SJ, Arculus RJ (2012b) Inter-element fractionation of highly siderophile elements in the Tonga Arc due to flux melting of a depleted source. Geochim Cosmochim Acta 89:202-225

Day JMD (2013) Hotspot volcanism and highly siderophile elements. Chem Geol 341:50-74

Day JMD, Walker RJ (2015) Highly siderophile element depletion in the Moon. Earth Planet Sci Lett 423:114-124

Day JMD, Hilton DR, Pearson, DG, Macpherson CG, Kjarsgaard BA, Janney PE (2005) Absence of a high time-integrated ${ }^{3} \mathrm{He} /(\mathrm{U}+\mathrm{Th})$ source in the mantle beneath continents. Geology 33, 733 736

Day JMD, Pearson DG, Taylor LA (2007) Highly siderophile element constraints on accretion and differentiation of the Earth-Moon system. Science 315:217-219

Day JMD, Pearson DG, Macpherson CG, Lowry D, Carracedo J-C (2009). Pyroxenite-rich mantle formed by recycled oceanic lithosphere: oxygen-osmium isotope evidence from Canary Island lavas. Geology 37:555-558

Day JMD, Walker RJ, James OB, Puchtel IS (2010a) Osmium isotope and highly siderophile element systematics of the lunar crust. Earth Planet Sci Lett 289:595-605

Day JMD, Pearson DG, Macpherson CG, Lowry D, Carracedo J-C (2010b) Evidence for distinct proportions of subducted oceanic crust and lithosphere in HIMU-type mantle beneath El Hierro and La Palma, Canary Islands. Geochim Cosmochim Acta 74:6565-6589

Day JMD, Walker RJ, Qin L, Rumble D (2012) Late accretion as a natural consequence of planetary growth. Nat Geosci 5:614-617

Day JMD, Brandon AD, Walker RJ (2015) Highly siderophile elements in terrestrial bodies. Rev Mineral Geochem 81:161-227

Day JMD, Waters CL, Schaefer BF, Walker RJ, Turner S (2015) Use of hydrofluoric acid desilicification in the determination of highly siderophile element abundances and Re-Pt-Os isotope systematics in mafic-ultramafic rocks. Geostandard and Geoanalytical Research doi: 10.1111/j.1751-908X.2015.00367.x

Debaille V, Trønnes RG, Brandon AD, Waight TE, Graham DW, Lee C-TA (2009) Primitive off-rift basalts from Iceland and Jan Mayen: Os-isotopic evidence for a mantle source containing enriched subcontinental lithosphere. Geochim Cosmochim Acta 73:3423-3449 
Deckart K, Bertrand H, Liegeois J-P (2005) Geochemistry and Sr, Nd, Pb isotopic composition of the Central Atlantic Magmatic Province (CAMP) in Guyana and Guinea. Lithos 82:289-314

DeMets C, Gordon RG, Argus DF (2010) Geologically current plate motions. Geophys J Internat 181:1-80

De Min A, Piccirillo EM, Marzoli A, Bellieni G, Renne PR, Ernesto M, Marques L (2003) The Central Atlantic Magmatic Province (CAMP) in Brazil: Petrology, Geochemistry, ${ }^{40} \mathrm{Ar} /{ }^{39} \mathrm{Ar}$ ages, paleomagnetism and geodynamic implications. In: Hames WE, McHone JG, Renne PR, Ruppel C (eds) The Central Atlantic Magmatic Province: Insights from Fragments of Pangea. Geophysical Monograph, Am Geophys Union 136:209-226

DePaulo DJ (1981) Trace element and isotopic effects of combined wallrock assimilation and fractional crystallization. Earth Planet Sci Lett 53:189-202

DePaolo DJ, Wasserburg GJ (1976) Nd isotopic variations and petrogenetic models. Geophys Res Lett 3:249-252

Dick HJB, Fisher RL, Bryan WB (1984) Mineralogic variability of the uppermost mantle along midocean ridge. Earth Planet Sci Lett 69:88-106

Dick HJB and 27 others (2000) A long in situ section of the lower ocean crust: Results of ODP Leg 176 drilling at the Southwest Indian Ridge. Earth Planet Sci Lett 179:31-51

Dorais MJ, Tubrett M (2008) Identification of a subduction zone component in the Higganum dyke, Central Atlantic Magmatic province: a LA-ICP-MS study of clinopyroxenes with implication for flood basalt petrogenesis. Geochem Geophys Geosys 9:Q10005, doi:10.1029/2008GC002079

Dosso L, Bougault H, Beuzart P, Calvez JY, Joron JL (1988) The geochemical structure of the South-East Indian ridge. Earth Planet Sci Lett 88:47-59

Dosso L, Bougault H, Joron JL (1993) Geochemical morphology of the North Mid-Atlantic Ridge, IO'-24’N: Trace element-isotope complementarity. Earth Planet Sci Lett 120:443-462

Drake M, Righter K (2002) Determining the composition of the Earth. Nature 416:39-44

Dungan MA, Rhodes JM (1978) Residual glasses and melt inclusions in basalts from DSDP Legs 45 and 46: evidence for magma mixing. Contrib. Mineral. Petrol. 67: 417-431.

Dupré $\mathrm{B}$, Allègre $\mathrm{CJ}$ (1983) $\mathrm{Pb}-\mathrm{Sr}$ isotope variation in Indian Ocean basalts and mixing phenomena. Nature 303:142-146

Ebel DS, Naldrett AJ (1997) Crystallization of sulfide liquids and the interpretation of ore composition. Can J Earth Sci 34:352-365

Eisele J, Sharma M, Galer SJG, Blichert-Toft J, Devey CW, Hofmann AW (2002) The role of sediment recycling in EM-1 inferred from $\mathrm{Os}, \mathrm{Pb}, \mathrm{Hf}, \mathrm{Nd}, \mathrm{Sr}$ isotopes and trace element systematics of the Pitcairn hotspot. Earth Planet Sci Lett 196:197-212

Ellam RM, Carlson RW, Shirey SB (1992) Evidence from Re-Os isotopes for plume lithosphere mixing in Karoo flood basalt genesis. Nature 359:718-721

Ernst RE, Buchan KL (2002). Maximum size and distribution in time and space of mantle plumes: evidence from large igneous provinces. J Geodyn 31:309-342

Ertel W, O'Neill HStC, Sylvester PJ and Dingwell DB (1999) Solubilities of Pt and Rh in haplobasaltic silicate melt at $1300{ }^{\circ} \mathrm{C}$. Geochim Cosmochim Acta 63:2439-2449

Ertel W, O’Neill HStC, Sylvester PJ, Dingwell DB, Spettel B (2001) The solubility of rhenium in silicate melts: implications for the geochemical properties of rhenium at high temperatures. Geochim Cosmochim Acta 65:2161-2170

Ertel W, Drake MJ, Walter MJ, Sylvester PJ (2006) Experimental study of platinum solubility in silicate melt to $14 \mathrm{GPa}$ and $2273 \mathrm{~K}$ : implications for accretion and core formation in Earth. Geochim Cosmochim Acta 70:2591-2602

Escrig S, Capmas F, Dupré B, Allègre CJ (2004) Osmium isotopic constraints on the nature of the DUPAL anomaly from Indian mid-ocean-ridge basalts. Nature 431:59-63 
Escrig S, Schiano P, Schilling J-G, Allègre CJ (2005a) Rhenium-osmium isotope systematics in MORB from the Southern Mid-Atlantic Ridge (40-50 ${ }^{\circ}$ S). Earth Planet Sci Lett 235:528-548

Escrig S, Doucelance R, Moriera M, Allègre CJ (2005b) Os isotope systematics in Fogo Island: evidence for lower continental crust fragments under the Cape Verde Southern Islands. Chem Geol 219:93-113

Falloon TJ, Danyushevsky LV, Ariskin A, Green DH, Ford CE (2007) The application of olivine geothermometry to infer crystallisation temperatures of parental liquids: implications for the temperature of MORB magmas. Chem Geol 241:207-233

Fischer-Gödde M, Becker H, Wombacher F (2011) Rhodium, gold and other highly siderophile elements in orogenic peridotites and peridotite xenoliths. Chem Geol 280:365-383

Fischer-Gödde M, Becker H (2012) Osmium isotope and highly siderophile element constraints on ages and nature of meteoritic components in ancient lunar impact rocks. Geochim Cosmochim Acta, 77:135-156

Fleet ME, Stone WE, Crocket JH (1991) Partitioning of palladium, iridium, and platinum between sulfide liquid and basalt melt: effects of melt composition, concentration and oxygen fugacity. Geochim Cosmochim Acta 55:2545-2554

Fleet ME, Crocket JH, Stone WE (1996) Partitioning of platinum group elements (Os, Ir, Ru, Pt, Pd) and gold between sulfide liquid and basalt melt. Geochim Cosmochim Acta 60:2397-2412

Foley S (1992) Petrological characterization of the source components of potassic magmas: geochemical and experimental constraints. Lithos 28:187-204

Fonseca ROC, Campbell IH, O'Neill HStC, Allen C,M (2009) Solubility of Pt in sulfide mattes: Implications for the genesis of PGE-rich horizons in layered intrusions. Geochim Cosmochim Acta 73:5764-5777

Fonseca ROC, Mallmann G, O’Neill HStC, Campbell IH, Laurenz V (2011) Solubility of Os and Ir in sulfide melt: Implications for Re/Os fractionation during mantle melting. Earth Planet Sci Lett 311-339-350

Fonseca ROC, Laurenz V, Mallmann G, Luguet A, Hoehne N, Jochum KP (2012) New constraints on the genesis and long-term stability of Os-rich alloys in the Earth's mantle. Geochim Cosmochim Acta 87:227-242

Fortenfant SS, Gunther D, Dingwell DB, Rubie DC (2003) Temperature dependence of Pt and Rh solubilities in a haplobasaltic melt. Geochim Cosmochim Acta 67:123-131

Fortenfant SS, Dingwell DB, Ertel-Ingrisch W, Capmas F, Birck JL, Dalpe C (2006) Oxygen fugacity dependence of Os solubility in haplobasaltic melt. Geochim Cosmochim Acta 70:742756

Gaetani GA, Grove TL (1997) Partitioning of moderately siderophile elements among olivine, silicate melt, and sulfide melt: Constraints on core formation in the Earth and Mars. Geochim Cosmochim Acta 61:1829-1846

Gaffney AM, Nelson BK, Reisberg L, Eiler J (2005) Oxygen-osmium isotope systematics of West Maui lavas: a record of shallow-level magmatic processes. Earth Planet Sci Lett 239:122-139

Gannoun A, Burton KW, Thomas LH, Parkinson IJ, Calsteren PV, Schiano P (2004) Osmium isotope heterogeneity in the constituent phases of mid-ocean ridge basalts. Science 303:70-72

Gannoun A, Burton KW, Vigier N, Gíslason S, Rogers NW, Mokadem M, Sigfússon B (2006) The influence of weathering process on riverine osmium isotopes in a basaltic terrain. Earth Planet Sci Lett 243:732-748

Gannoun A, Burton KW, Parkinson IJ, Alard O, Schiano P, Thomas LE (2007) The scale and origin of the osmium isotope variations in mid-ocean ridge basalts. Earth Planet Sci Lett 259:541-556

Gannoun A, Burton KW (2014) High precision osmium elemental and isotope measurements of North Atlantic seawater. J Anal At Spectrom 29:2330-2342 
Gannoun A, Burton KW, Barfod DN, Schiano P, Vlastélic I, Halliday AN (2015a) Resolving mantle and magmatic processes in basalts from the Cameroon volcanic line using the Re-Os isotope system. Lithos 224-225:1-12

Gannoun A, Vlastélic I, Schiano P (2015b) Escape of unradiogenic osmium during sub-aerial lava degassing: Evidence from fumarolic deposits, Piton de la Fournaise, Réunion Island. Geochim Cosmochim Acta 166:312-326

Gao S, Rudnick RL, Xu WL, Yuan HL, Liu YS, Walker RJ, Puchtel IS, Liu X, Huang H, Wang XR, Yang J ( 2008) Recycling deep cratonic lithosphere and generation of intraplate magmatism in the North China Craton. Earth Planet Sci Lett 270:41-53

Gibson SA, Thompson RN, Day JA (2006) Timescales and mechanisms of plume-lithosphere interactions: 40Ar/39Ar geochronology and geochemistry of alkaline igneous rocks from the Paraná-Etendeka large igneous province. Earth Planet Sci Lett 251:1-17

Gill J, Williams R, Bruland K (1985) Eruption of basalt and andesite lava degasses ${ }^{222} \mathrm{Rn}$ and ${ }^{210} \mathrm{Po}$. Geophys Res Lett 12:17-20

Godard M, Lagabrielle Y, Alard O, Harvey J (2008) Geochemistry of the highly depleted peridotites drilled at ODP Sites 1272 and 1274 (Fifteen-Twenty Fracture Zone, Mid-Atlantic Ridge): Implications for mantle dynamics beneath a slow spreading ridge. Earth Planet Sci Lett 267:410-425

González-Jiménez JM, Gervilla F, Proenza JA, Kerestedjian T, Augé T, Bailly L (2009) Zoning of laurite $\left(\mathrm{RuS}_{2}\right)$-erlichmanite $\left(\mathrm{OsS}_{2}\right)$ : implications for the origin of PGM in ophiolite chromitites. Eur J Mineral 21:419-432

González-Jiménez JM, Proenza JA, Gervilla F, Melgarejo JC, Blanco-Moreno JA, Ruiz-Sánchez R, Griffin WL (2011) High-Cr and high-Al chromitites from the Sagua de Tánamo district, Mayarí-Cristal ophiolitic massif (eastern Cuba): Constraints on their origin from mineralogy and geochemistry of chromian spinel and platinum-group elements. Lithos 125:101-121

Green DH (1971) Compositions of basaltic magmas as indicators of conditions of origin: application to oceanic volcanism. Phil Trans R Soc Lond Ser A 268:707-725

Grimes CB, John BE, Cheadle MJ, Wooden JL (2008) Protracted construction of gabbroic crust at a slow spreading ridge: Constraints from 206Pb238U zircon ages from Atlantis Massif and IODP Hole U1309D (30 N, MAR). Geochem Geophys Geosyst 9. http://dx.doi.org/10.1029/2008GC002063

Grove TL, Kinzler, RJ, Bryan, WB (1993) Fractionation of mid-ocean ridge basalt (MORB). In: Mantle Flow and Melt Migration at Mid-Ocean Ridges, Phipps-Morgan J. et al. (ed) American Geophysical Monograph 71:281-311

Gudfinnsson GH, Presnall DC (2005) Continuous gradations among primary carbonatitic, kimberlitic, melilititic, basaltic, picritic, and komatiitic melts in equilibrium with garnet lherzolite at 3-8 GPa. J Petrol 46:1645-1659

Haggerty SE (1999) A diamond trilogy: superplumes, supercontinents and supernovae. Science 285:851-860

Hamelin B, Allègre CJ (1985) Large-scale units in the depleted upper mantle revealed by an isotope study of the Southwest Indian Ridge. Nature 315:196-199

Hamelin B, Dupre D, Allègre CJ (1984) Lead-strontium isotopic variations along the East Pacific Rise and the Mid-Atlantic Ridge: a comparative study. Earth Planet Sci Lett 67:340-350

Hamelin B, Dupre D, Allègre CJ (1986) Pb-Sr-Nd isotopic data of Indian Ocean ridges: new evidence of large-scale mapping of mantle heterogeneities. Earth Planet Sci Lett 76:286-296

Hanyu T, Tatsumi Y, Senda R, Miyazaki T, Chang Q, Hirahara Y, Takahashi T, Kawabata H, Suzuki K, Kimura J-I (2011), Geochemical characteristics and origin of the HIMU reservoir: A possible mantle plume source in the lower mantle. Geochem Geophys Geosyst 12: Q0AC09, doi:10.1029/2010GC003252. 
Hart SR (1984) A large-scale isotope anomaly in the southern hemisphere mantle. Nature 309:753757

Hart SR, Ravizza G (1996) Os partitioning between phases in lherzolite and basalt. In: Earth Processes: Reading the isotopic Code. Union Geophys Monogr. Vol 95. Basu A, Hart SR (ed), p 123-134

Hart SR, Gaetani GA (2006) Mantle Pb paradoxes: the sulfide solution. Contrib Mineral Petrol 152:295-308

Hart SR, Blusztajn J, Dick HJB, Meyer PS, Muehlenbachs K (1999) The fingerprint of seawater circulation in a 500-meter section of ocean crust gabbro. Geochim Cosmochim Acta 63:40594080

Harvey J, Gannoun A, Burton KW, Rogers NW, Alard O, Parkinson IJ (2006) Ancient melt extraction from the oceanic upper mantle revealed by Re-Os isotopes in abyssal peridotites from the Mid-Atlantic ridge. Earth Planet Sci Lett 244:606-621

Harvey J, Gannoun A, Burton KW, Rogers NW, Schiano P, Alard O (2010) Unravelling the effects of melt depletion and secondary infiltration on mantle Re-Os isotopes beneath the French Massif Central. Geochim Cosmochim Acta 74:293-320

Harvey J, Dale CW, Gannoun A, Burton KW (2011) Osmium mass balance in peridotite and the effects of mantle-derived sulfides on basalt petrogenesis. Geochim Cosmochim Acta 75:55745596

Harvey J, Savov IP, Agostini S, Cliff RA, Walshaw RD (2014a) Si-metasomatism in serpentinized peridotite: the effects of talc-alteration on strontium and boron isotopes in abyssal peridotites from Hole 1268a, ODP Leg 209. Geochim Cosmochim Acta 126:30-48

Harvey J, Garrido CJ, Savov I, Agostini S, Padrón-Navarta JA, Marchesi C, Lopez Sánchez-Vizcaíno V, Gómez-Pugnaire MT (2014b). ${ }^{11}$ B-rich fluids in subduction zones: the role of antigorite dehydration in subducting slabs and boron isotope heterogeneity in the mantle. Chem Geol 376:20-30

Harvey J, Warren JM, Shirey SB (2015) Mantle sulfides and their role in Re-Os and Pb isotope geochronology. Rev Mineral Geochem 81:579-635

Hauri EH, (2002) Osmium isotopes and mantle convection. Phil Trans R Soc Lond 360:2371-2382

Hauri EH, Hart SR (1993) Re-Os isotope systematics of HIMU and EMII oceanic island basalts from the South Pacific Ocean. Earth Planet Sci Lett 114-353-371

Hauri EH, Hart SR (1997) Rhenium abundances and systematics in oceanic basalts. Chem Geol 139:185-205

Hayashi HE, Ohtani E, Terasaki H, Ito Y (2009) The partition of Pt-Re-Os between solid and liquid metal in the Fe-Ni-S system at high pressure: implications for inner core fractionation. Geochim Cosmochim Acta 73:4836-4842

Heinonen JS, Carlson RW, Luttinen AV (2010) Isotopic ( $\mathrm{Sr}, \mathrm{Nd}, \mathrm{Pb}$, and Os) composition of highly magnesian dykes of Vestfjella, western Dronning Maud Land, Antarctica: A key to the origins of the Jurassic Karoo large igneous province? Chem Geol 277:227-244

Heinonen J, Carlson RW, Riley TR, Luttinen AV, Horan MF (2014) Subduction-modified oceanic crust mixed with a depleted mantle reservoir in the sources of the Karoo continental flood basalt province. Earth Planet Sci Lett 394:229-241

Hill RI (1991) Starting plumes and continental break-up. Earth Planet Sci Lett 104:398-416

Hill E, Wood BJ, Blundy JD (2000) The effect of Ca-Tschermaks component on trace element partitioning between clinopyroxene and silicate melt. Lithos 53:203-215

Hirschmann MM, Stolper EM (1996) A possible role for garnet pyroxenite in the origin of the 'garnet signature' in MORB. Contrib Mineral Petrol 124(2):185-208

Hirschmann MM, Kogiso T, Baker MB, Stolper EM (2003) Alkalic magmas generated by partial melting of garnet pyroxenite. Geology 31:481-484 
Hirt B, Tilton GR, Herr W, Hoffmeister W (1963) The half life of ${ }^{187}$ Re. In: Geiss, J. and Goldberg, E. (Eds), Earth Science Meteoritics. North Holland Pub., pp. 273-280.

Hirth G, Kohlstedt DL (1996) Water in the oceanic upper mantle: implications for rheology, melt extraction and the evolution of the lithosphere. Earth Planet Sci Lett 144:93-108

Hofmann AW (1997) Mantle geochemistry: the message from oceanic volcanism. Nature 385:219229

Hofmann AW (2003) Sampling mantle heterogeneity through oceanic basalts: isotopes and trace elements, in: Carlson RW (ed), The Mantle, Treatise on Geochemistry vol. 2 (eds Holland HD, Turekian KK). Elsevier-Pergamon, Oxford, pp. 61-101

Hofmann AW, Hart SR (1978) An assessment of local and regional isotopic equilibrium in the mantle. Earth Planet Sci Lett 38:44-62Holzheid A, Sylvester P, O'Neill HStC, Rubie DC, Palme H (2000) Evidence for a late chondritic veneer in the Earth's mantle from high-pressure partitioning of palladium and platinum. Nature 406:396-399

Holzheid A, Sylvester P, O’Neill HStC, Rubie DC, Palme H (2000) Evidence for a late chondritic veneer in the Earth's mantle from high-pressure partitioning of palladium and platinum. Nature 406:396-399

Horan MF, Walker RJ, Fedorenko VA, Czamanske GK (1995) Osmium and neodymium isotopic constraints on the temporal and spatial evolution of Siberian flood basalt sources. Geochim Cosmochim Acta 59:5159-5168

Horan MF, Walker RJ, Morgan JW, Grossman JN, Rubin A (2003) Highly siderophile elements in chondrites. Chem Geol 196:5-20

Ireland TJ, Walker RJ, Garcia MO (2009) Highly siderophile element and ${ }^{187}$ Os isotope systematics of Hawaiian picrites: implications for parental melt composition and source heterogeneity. Chem Geol 260:112-128

Ireland TJ, Walker RJ, Brandon AD (2011) ${ }^{186}$ Os- ${ }^{187}$ Os systematics of Hawaiian picrites revisited: new insights into Os isotopic variations in ocean island basalts. Geochim Cosmochim Acta 75:4456-4475

Ishikawa T, Tera F, Nakazawa T (2001) Boron isotope and trace element systematics of the three volcanic zones in the kamchatka arc. Geochim Cosmochim Acta 65:4523-4537

Ishikawa A, Senda R, Suzuki K, Dale CW, Meisel T (2014) Re-evaluating digestion methods for highly siderophile element and ${ }^{187}$ Os isotope analysis: Evidence from geological reference materials. Chem Geol 384:27-46

Jackson MG, Shirey SB (2011) Re-Os isotope systematics in Samoan shield lavas and the use of Osisotopes in olivine phenocrysts to determine primary magmatic compositions. Earth Planet Sci Lett 312:91-101

Jamais M, Lassiter JC, Brügmann G (2008) PGE and Os-isotopic variations in lavas from Kohala Volcano, Hawaii: constraints on PGE behaviour and melt-crust interaction. Chem Geol 250:1628

Jambon A, Druelle B, Dreibus G, Pineau F (1995) Chlorine and bromine abundance in MORB: the contrasting behaviour of the Mid-Atlantic Ridge and East Pacific Rise and implications for chlorine geodynamic cycle. Chem Geol 126:101-117

Jenner FE, O'Neill HStC (2012) Analysis of 60 elements in 616 ocean floor basaltic glasses. Geochem Geophys Geosys 13. http://dx.doi.org /10.1029/2011/GC004009.

Johnson KTM, Dick HJB (1992) Open system melting and temporal and spatial variation of peridotite and basalt at the Atlantis II fracture zone. J Geophys Res 97:9219-9241

Jones JH, Drake MD (1986) Geochemical constraints on core formation in the Earth. Nature 322:221-228

Katz RF, Weatherley SM (2012) Consequences of mantle heterogeneity for melt extraction at midocean ridges. Earth Planet Sci Lett 335-336:226-237 
Kay RW (1985) Island arc processes relevant to crustal and mantle evolution. Tectonophysics 112:115

Keays RR, Lightfoot PC (2007) Siderophile and chalcophile metal variations in Tertiary picrites and basalts from West Greenland with implications for the sulfide saturation history of continental flood basalt magmas. Miner Deposita 42:319-336

Kent AJR, Stolper EM, Francis D, Woodhead J, Frei R, Eiler J (2004) Mantle heterogeneity during the formation of the North Atlantic Igneous Province: constraints from trace elements and SrNd-Os-O isotope systematics of Baffin Island picrites. Geochem Geophys Geosys 5:Q11004, http://dx.doi.org/10.1029/2004GC000743

Kerr AC, Mahoney JJ (2007) Oceanic plateaus: problematic plumes, potential paradigms. Chem Geol 241:332-353

Kimura K, Lewis RS, Anders E (1974) Distribution of gold and rhenium between nickel-iron and silicate melts: implications for the abundance of siderophile elements on the Earth and Moon. Geochim Cosmochim Acta 38:683-701

Kiseeva ES, Wood BJ (2015) The effects of composition and temperature on chalcophile and lithophile element partitioning into magmatic sulphides. Earth Planet Sci Lett 424:280-294

Klein EM, Langmuir CH (1987) Global correlations of ocean ridge basalt chemistry with axial depth and crustal thickness. J Geophys Res 92:8089-8115

Kogiso T, Hirschmann MM, Pertermann M (2004) High-pressure partial melting of mafic lithologies in the mantle. J Petrol 45:2407-2422

Kogiso T, Suzuki K, Suzuki T, Shinotsuka K, Uesugi K, Takeuchi A, Suzuki Y (2008) Detecting micrometer-scale platinum-group minerals in mantle peridotite with microbeam synchrotron radiation X-ray fluorescence analysis. Geochem Geophys Geosys 9. http://dx.doi.org/10.1029/2007/GC001888.

Kumar N, Reisberg L, Zindler A (1996) A major and trace element and strontium, neodymium, and osmium isotopic study of a thick pyroxenite layer from the Beni Bousera Ultramafic Complex of northern Morocco. Geochim Cosmochim Acta 60:1429-1444

Kwékam M, Affaton P, Bruguier B, Liégeois JP, Hartmann G, Njonfang E (2013) The Pan-African Kekem gabbro-norite (West-Cameroon), U-Pb zircon age, geochemistry and $\mathrm{Sr}-\mathrm{Nd}$ isotopes: geodynamical implication for the evolution of the Central African fold belt. J Afr Earth Sci 84:70-88

Lambart S, Laporte D, Provost A, Schiano P (2012) Fate of pyroxenite-derived melts in the peridotitic mantle: thermodynamic and experimental constraints. J Petrol 53:451-476

Lambart S, Laporte D, Schiano P (2013) Markers of the pyroxenite contribution in the major-element compositions of oceanic basalts: Review of the experimental constraints. Lithos 160-161:14-36

Lambert G, Le Cloarec MF, Ardouin B, Le Roulley JC (1986) Volcanic emission of radionuclides and magma dynamics. Earth Planet Sci Lett 76:185-192

Lassiter JC (2003) Rhenium volatility in subaerial lavas: Constraints from subaerial and submarine portions of the HSDP-2 Mauna Kea drillcore. Earth Planet Sci Lett 214:311-325

Lassiter JC, Hauri EH (1998) Osmium-isotope variations in Hawaiian lavas: evidence for recycled oceanic lithosphere in the Hawaiian plume. Earth Planet Sci Lett 164:483-496

Lassiter JC, Luhr JF (2001) Osmium abundance and isotope variations in mafic Mexican volcanic rocks: evidence for crustal contamination and constraints on the geochemical behavior of osmium during partial melting and fractional crystallization. Geochem Geophys Geosys 2:1027. http://dx.doi.org/10.1029/2000GC000116

Lassiter JC, Hauri EH, Reiners PW, Garcia MO (2000) Generation of Hawaiian post erosional lavas by melting of a mixed lherzolite/pyroxenite source. Earth Planet Sci Lett 178:269-284

Lassiter JC, Blichert-Toft J, Hauri EH, Barsczus HG (2003) Isotope and trace element variations in lavas from Raivavae and Rapa, Cook-Austral Islands: constraints on the nature of HIMU- and 

EM-mantle and the origin of mid-plate volcanism in French Polynesia. Chem Geol 202:115138

Lassiter JC, Byerly BL, Snow JE, Hellebrand E (2014) Constraints from Os-isotope variations on the origin of Lena Trough abyssal peridotites and implications for the composition and evolution of the depleted upper mantle. Earth Planet Sci Lett 403:178-187

Laurenz V, Fonseca ROC, Ballhaus C, Jochum KP, Heuser A, Sylvester PJ (2013) Solubility of palladium and ruthenium in picrite melts: 2. The effect of sulfur. Geochim Cosmochim Acta 108:172-183

Lee D-C, Halliday AN, Davies GR, Essene EJ, Fitton JG, Temdjim R. (1996) Melt enrichment of shallow depleted mantle: a detailed petrological, trace element and isotopic study of mantlederived xenoliths and megacrysts from the Cameroon line. J Petrol 37: 415-441

Lecuyer C and Reynard B (1996) High-temperature alteration of oceanic gabbros by seawater (Hess Deep, Ocean Drilling Program Leg 147): Evidence from oxygen isotopes and elemental fluxes. J Geophys Res 101:15883-15897

Leeman WP, Tonarini S, Chan LH, Borg LE (2004) Boron and lithium variations in a hot subduction zone, the southern Washington Cascades. Chem Geol 212:101-124

Le Roex AP, Erlank AJ, Needham HD (1981) Geochemical and mineralogical evidence for the occurrence of at least three distinct magma types in the 'famous' region. Contrib Mineral Petrol 77:24-37

Levasseur S, Birk J-L, Allègre CJ (1998) Direct measurement of femtomoles of osmium and the 187Os/186Os in seawater. Science 282:272-274

Levasseur S, Birck JL, Allègre CJ (1999) The osmium riverine flux and the oceanic mass balance of osmium. Earth Planet Sci Lett 174:7-23

Li J, Xu J-F, Suzuki K, He B, Xu Y-G, Ren Z-Y (2010) Os, Nd and Sr isotope and trace element geochemistry of the Muli picrites: insights into the mantle source of the Emeishan large igneous province. Lithos 119:108-122

Li J, Wang XC, Ren ZY, Xu JF, He B, Xu YG (2014) Chemical heterogeneity of the Emeishan mantle plume: evidence from highly siderophile element abundances in picrites. J Asian Earth Sciences 79:191-205

Lissenburg CJ, Rioux M, Shimizu N, Bowring SA, Mével, C (2009) Zircon dating of oceanic crustal accretion. Science 323:1048-1050

Liu CZ, Snow JE, Hellebrand E, Brügmann, G, von der Handt A, Büchl A, Hofmann AW (2008) Ancient, highly heterogeneous mantle beneath Gakkel ridge, Arctic Ocean. Nature 452:311-316

Lodders K. (2003) Solar system abundances and condensation temperatures of the elements. Astrophys J 591:1220-1247

Lodders K, Palme H, Gail HP (2009) Abundances of the elements in the solar system. In: LandoltBörnstein, New Series, Vol VI/4B. J.E. Trümper JE (ed), Springer-Verlag, Berlin, p 560-630

Lorand J-P (1990) Are spinel lherzolite xenoliths representative of the sulfur content of the upper mantle. Geochim Cosmochim Acta 54:1487-1492

Lorand J-P, Luguet A (2015) Chalcophile and siderophile elements in mantle rocks : trace elements controlled by trace minerals. Rev Geochem Mineral 81:441-481

Lorand J-P, Alard O (2001) Platinum-group element abundances in the upper mantle: new constraints from in situ and whole-rock analyses of Massif Central xenoliths (France). Geochim Cosmochim Acta 65: 2789-2806

Lorand J-P, Alard O, Luguet A (2010) Platinum-group element micronuggets and refertilization process in Lherz orogenic massif (northeastern Pyrenees, France). Earth Planet Sci Lett 289:298-310

Lorand J-P, Luguet A, Alard O (2013) Platinum-group element systematics and petrogenetic processing of the continental upper mantle: A review. Lithos 164-167:1-21 
Luck JM, Allègre CJ (1982) The study of molybdenites through the ${ }^{187} \mathrm{Re}^{187}$ Os chronometer. Earth Planet Sci Lett 61:291-296

Luguet A, Lorand JP, Seyler M (2003) Sulfide petrology and highly siderophile element geochemistry of abyssal peridotites: A coupled study of samples from the Kane Fracture Zone $\left(45^{\circ} \mathrm{W} 23^{\circ} 20 \mathrm{~N}\right.$, MARK area, Atlantic Ocean). Geochim Cosmochim Acta 67:1553-1570

Luguet A, Shirey SB, Lorand JP, Horan MF, Carlson RW (2007) Residual platinum group minerals from highly depleted harzburgites of the Lherz massif (France) and their role in HSE fractionation in the mantle. Geochim Cosmochim Acta 71:3082-3097

Luguet A, Pearson DG, Nowell GM, Dreher ST, Coggon JA, Spetsius ZV, Parman SW (2008) Enriched Pt-Re-Os isotope systematics in plume lavas explained by metasomatic sulfides. Science 319:453-456

Mahoney JJ, Natland JH, White WM, Poreda R, Bloomer SH, Fisher RL, Baxter AN (1989) Isotopic and geochemical provinces of the Western Indian Ocean spreading centers. J Geophys Res 94:4033-4052

Mahoney JJ, LeRoex AP, Peng Z, Fisher RL, Natland JH (1992) Southwestern limits of Indian Ocean ridge mantle and the origin of low ${ }^{206} \mathrm{~Pb} /{ }^{204} \mathrm{~Pb}$ mid-ocean ridge basalt: isotope systematics of the central Southwest Indian Ridge (178-508E). J Geophys Res 97:19771-19790

Mallmann G, O'Neill HStC (2007) The effect of oxygen fugacity on the partitioning of Re between crystals and silicate melt during mantle melting. Geochim Cosmochim Acta 71:2837-2857

Mann U, Frost DJ, Rubie DC, Becker H, Audétat A (2012) Partitioning of Ru, Rh, Pd, Re, Ir and Pt between liquid metal and silicate at high pressures and temperatures- implications for the origin of highly siderophile element concentrations in the Earth's mantle. Geochim Cosmochim Acta 84:593-613

Marcantonio F, Zindler A, Elliott T, Staudigel H (1995) Os isotope systematics of La Palma, Canary Islands: evidence for recycled crust in the mantle source of HIMU ocean islands. Earth Planet Sci Lett 133:397-410

Marchesi C, Dale CW, Garrido CJ, Pearson DG, Bosch D, Bodinier J-L, Gervilla F, Hidas K (2014) Fractionation of highly siderophile elements in refertilized mantle: Implications for the Os isotope composition of basalts. Earth Planet Sci Lett 400:33-44

Martin CE (1991) Osmium isotopic characteristics of mantle-derived rocks. Geochim Cosmochim Acta 55:1421-34

Mathez EA (1976) Sulfur solubility and magmatic sulfides in sub-marine basalt glasses. J Geophys Res 81:4269-4276

Mathez EA, Yeats RS (1976) Magmatic sulfides in basalt glass from DSDP hole 319a and site 320, Nazca plate. Initial Reports of the Deep-Sea Drilling Project 34:363-373

Mather TA, Witt MLI, Pyle DM, Quayle BM, Aiuppa A, Bagnato E, Martin RS, Sims KWW, Edmonds M, Sutton AJ, Ilyinskaya E (2012) Halogens and trace metal emissions from the ongoing 2008 summit eruption of Kilauea volcano, Hawaii. Geochim Cosmochim Acta 83:292323

Mavrogenes JA, O'Neill HStC (1999) The relative effects of pressure, temperature and oxygen fugacity on the solubility of sulfide in mafic magmas. Geochim Cosmochim Acta 63:1173-1180

May PR (1971) Pattern of Triassic diabase dykes around the North Atlantic in the context of predrift position of the continents. Geol Soc Am Bull 82:1285-1292

McHone JG (2000). Non-plume magmatism and rifting during the opening of the Central Atlantic Ocean. Tectonophysics 316:287-296

McHone JG, Anderson DL, Beutel EK, Fialko YA (2005) Giant dikes, rifts, flood basalts, and plate tectonics: A contention of mantle models. In: Foulger GR, Natlund JH, Presnall DC, Anderson DL (eds) In: Plates, Plumes, and Paradigms, Geol Soc Am Special Paper 388:401-420

McInnes BIA, McBride JS, Evans NJ,Lambert DD, Andrew AS (1999) Osmium isotope constraints on ore metal recycling in subduction zones. Science 286:512-516 
McDonough WF, Sun SS (1995) The chemical composition of the Earth. Chem Geol 120:223-253

Meisel T, Walker RJ, Morgan JW (1996) The osmium isotopic composition of the Earth's primitive upper mantle. Nature 383:517-520

Meisel T, Walker RJ, Irving AJ, Lorand JP (2001) Osmium isotopic compositions of mantle xenoliths: a global perspective. Geochim Cosmochim Acta 65:1311-1323

Meisel T, Reisberg L, Moser J, Carignan J, Melcher F, Brügmann G (2003) Re-Os systematics of UB-N, a serpentinized peridotite reference material. Chem Geol 201:161-179

Merle R, Marzoli A, Reisberg L, Bertrand H, Nemchin A, Chiaradia M, Callegaro S, Jourdan F, Bellieni G, Kontak D, Puffer J, McHone JG (2014) Sr, Nd, Pb and Os isotope systematics of CAMP tholeiites from eastern North America (ENA): evidence of a subduction-enriched mantle source. J Petrol 55:133-180

Michael PJ, Schilling JG (1989) Chlorine in mid-ocean ridge magmas: Evidence for assimilation of seawater-influenced components. Geochim Cosmochim Acta 53:3131-3143

Michael PJ, Cornell WC (1998) Influence of spreading rate and magma supply on crystallization and assimilation beneath mid-ocean ridges: Evidence from chlorine and major element chemistry of mid-ocean ridge basalts. J Geophys Res 103:18325-18356

Michard A, Montigny R, Schlich R (1986) Geochemistry of the mantle beneath the Rodriguez Triple Junction and the South-East Indian Ridge. Earth Planet Sci Lett 78:104-114

Mitchell RH, Keays RR (1981) Abundance and distribution of gold, palladium and iridium in some spinel and garnet lherzolites: implications for the nature and origin of precious metal-rich intergranular components in the upper mantle. Geochim Cosmochim Acta 45:2425-2442

Molski MJ, Seppelt K (2009) The transition metal hexafluorides. Dalton Trans 3379:3379-3383.

Molzahn M, Reisberg L, Worner G (1996) Os, Sr, Nd, Pb, O isotope and trace element data from the Ferrar flood basalts, Antarctica: evidence for an enriched subcontinental lithospheric source. Earth Planet Sci Lett 144:529-546

Momme P, Oskarsson N, Keays RR (2003) Platinum-group elements in the Icelandic rift system: melting processes and mantle sources beneath Iceland. Chem Geol 196:209-234

Momme P, Tegner C, Brooks CK, Keays RR (2006) Two melting regimes during Paleogene flood basalt generation in East Greenland: combined REE and PGE modeling. Contrib Mineral Petrol 151:88-100

Moore JG, Calk LC (1971) Sulfide spherules in vesicles of dredge pillow basalt. Am Mineral 56.476488

Moore JG Schilling JG (1973) Vesicles, water, and sulfur in Reykjanes Ridge basalt. Contrib Mineral Petrol 41:105-118

Moore A., Coogan L. A., Costa F. and Perfit M. R. (2014) Primitive melt replenishment and crystalmush disaggregation in the weeks preceding the 2005-2006 eruption $9^{\circ} 50 \mathrm{~N}, \mathrm{EPR}$. Earth Planet Sci Lett 403:15-26

Moran AE, Sisson VB, Leeman WP (1992) Boron depletion during progressive metamorphism: Implications for subduction processes. Earth Planet Sci Lett 111:331-349

Morgan WJ (1971) Convection plumes in the lower mantle. Nature 230:42-43

Morgan WJ (1983). Hotspot tracks and the early rifting of the Atlantic. Tectonophysics 94:123-139

Mungall JE (2002) Roasting the mantle: slab melting and the genesis of major $\mathrm{Au}$ and $\mathrm{Au}$-rich $\mathrm{Cu}$ deposits. Geology 30:915-918

Mungall JE, Brenan JM (2014) Partitioning of platinum-group elements and Au between sulfide liquid and basalt and the origins of mantle-crust fractionation of the chalcophile elements. Geochim Cosmochim Acta 125:265-289

Mungall JE, Hanley JJ, Arndt NT, Debecdelievre A (2006) Evidence from meimechites and other low-degree mantle melts for redox controls on mantle-crust fractionation of platinum group elements. Proc Natl Acad Sci 103:12695-12700

Murthy V (1991) Early differentiation of the Earth and the problem of mantle siderophile 
Nakagawa M, Franco HEA (1997) Placer Os-Ir-Ru alloys and sulfides: indicators of sulfur fugacity in an ophiolite? Can Mineral 35:1441-1452

Nakano N, Nakamura E (2001) Boron isotope chemistry of metasedimentary rocks and toumalines in a subduction zone metamorphic suite. Phys Earth Planet Inter 127:233-252

Niu Y (2004) Bulk-rock major and trace element compositions of abyssal peridotites: implications for mantle melting, melt extraction and post melting processes beneath mid-ocean ridges. J. Petrol. 45(12):2423-2458

Norman MD, Garcia MO, Bennett VC (2004) Rhenium and chalcophile elements in basaltic glasses from Ko'olau and Moloka'i volcanoes: magmatic outgassing and composition of the Hawaiian plume. Geochim Cosmochim Acta 68:3761-3777

O’Driscoll B, González-Jiménez J-M (2015) An inventory and overview of natural occurrences of the platinum-group minerals (PGM) in extraterrestrial and terrestrial rocks. Rev Mineral Geochem 81:489-576

O'Driscoll B, Day JMD, Daly JS, Walker RJ, McDonough WF (2009) Rhenium-osmium isotope and platinum-group elements in the Rum Layered Suite, Scotland: implications for Cr-spinel seam formation and the composition of the Iceland mantle anomaly. Earth Planet Sci Lett 286:41-51

Ohtani E, Yurimoto H (1996) Element partitioning between metallic liquid, magnesiowustite, and silicate liquid at $20 \mathrm{GPa}$ and $2500^{\circ} \mathrm{C}$ : A secondary ion mass spectroscopic study. Geophys Res, Lett 23:1993-1996

O'Neill HStC (1991) The origin of the Moon and early history of the Earth - a chemical model: Part 2. The Earth. Geochim Cosmochim Acta 55:1159-1172

O'Neill HStC, Mavrogenes J (2002) The sulfide capacity and the sulfur content at sulfide saturation of silicate melts at $1400^{\circ} \mathrm{C}$ and 1 bar. J Petrol 43:1049-1087

O'Neill HStC, Dingwell DB, Borisov A, Spettel B, Palme H (1995) Experimental petrochemistry of some highly siderophile elements at high temperatures, and some implications for core formation and the mantle's early history. Chem Geol 120:255-273

O'Nions RK, Hamilton PJ, Evenson AM (1977) Variations in ${ }^{143} \mathrm{Nd} /{ }^{144} \mathrm{Nd}$ and ${ }^{87} \mathrm{Sr} /{ }^{86} \mathrm{Sr}$ ratios in oceanic basalts. Earth Planet Sci Lett 34:13-22

Palme H, O'Neill HStC (2003) Cosmochemical estimates of mantle composition. In: Treatise on Geochemistry, The Mantle and Core (ed) Carlson RW. Elsevier, Amsterdam. p 1-38

Patten C, Barnes SJ, Mathez EA (2012) Textural variations in MORB sulfide droplets due to differences in crystallization history. Can Mineral 50:675-692

Patten C, Barnes SJ, Mathez EA, Jenner FE (2013) Partition coefficients of chalcophile elements between sulfide and silicate melts and the early crystallization history of sulfide liquid: LAICP-MS analysis of MORB sulfide droplets. Chem Geol 358:170-188

Peach CL, Mathez EA, Keays RR (1990) Sulfide melt-silicate melt distribution coefficients for noble metals and other chalcophile elements as deduced from MORB: implications for partial melting. Geochim Cosmochim Acta 54:3379-3389

Peach CL, Mathez EA, Keays RR, Reeves SJ (1994) Experimentally determined sulfide melt-silicate melt partition coefficient for iridium and palladium. Chem Geol 117:361-377

Peacock SM, Hervig RL (1999) Boron isotopic composition of subduction-zone metamorphic rocks. Chem Geol 160:281-290

Pearson DG, Carlson RW, Shirey SB, Boyd FR, Nixon PH (1995) The Stabilisation of Archean lithospheric mantle: a Re-Os isotope study of peridotite xenoliths from the Kaapvaal craton. Earth Planet Sci Lett 134:341-357

Pearson DG, Davies GR, Nixon PH, Greenwood PB, Mattey DP (1991) Oxygen isotope evidence for the origin of pyroxenites in the Beni Bousera peridotite massif N. Morocco: derivation from subducted oceanic lithosphere. Earth Planet Sci Lett 102:289-301 
Pearson DG, Shirey SB,Harris JW,Carlson RW (1998) Sulfide inclusions in diamonds from the Koffiefontein kimberlite, S. Africa: Constraints on diamond ages and mantle Re-Os systematics. Earth Planet Sci Lett 160:311-326

Pearson DG, Shirey SB, Bulanova GP, Carlson RW, Milledge HJ (1999) Re-Os isotope measurements of single sulfide inclusions in a Siberian diamond and its nitrogen aggregation systematics. Geochim Cosmochim Acta 63:703-711

Pearson DG, Irvine GJ, Ionov DA, Boyd FR, Dreibus GE (2004) Re-Os isotope systematics and platinum group element fractionation during mantle melt extraction: A study of massif and xenolith peridotite suites. Chem Geol 208:29-59

Pearson DG, Nowell GM, Kjarsgaard BA, Dowall DP (2008) The genesis of kimberlite: geochemical constraints. Ext Abs 9th Int Kimb Conf Frankfurt (No.9IKC-A-00149)

Pearson NJ, Alard O, Griffin WL, Jackson SE, O'Reilly SY (2002) In situ measurement of Re-Os isotopes in mantle sulfides by laser ablation multicollector-inductively coupled plasma mass spectrometry: analytical methods and preliminary results. Geochim Cosmochim Acta 66:10371050

Pegram BJ, Allègre CJ (1992) Osmium isotopic compositions from oceanic basalts. Earth Planet Sci Lett 111:59-68

Penniston-Dorland SC, Walker RJ, Pitcher L, Sorensen SS (2012) Mantle-crust interactions in a paleosubduction zone: Evidence from highly siderophile element systematics of eclogite and related rocks. Earth Planet Sci Lett 319-320, 295-306

Penniston-Dorland SC, Gorman JK, Bebout GE, Piccoli PM., Walker RJ (2014) Reaction rind formation in the Catalina Schist: Deciphering a history of mechanical mixing and metasomatic alteration. Chem Geol 384:47-61

Peslier AH, Reisberg L, Ludden J, Francis D (2000) Os isotopic systematics in mantle xenoliths; age constraints on the Canadian Cordillera lithosphere. Chem Geol 166:85-101

Peucker-Ehrenbrink B, Ravizza G, Hofmann AW (1995) The marine ${ }^{187}$ Os/ $/{ }^{186}$ Os record of the past 80 million years. Earth Planet Sci Lett 130:155-167

Peucker-Ehrenbrink B, Bach W, Hart SR, Blusztajn J, Abbruzzese T (2003) Rhenium-osmium isotope systematics and platinum group element concentrations in oceanic crust from DSDP/ODP Sites 504 and 417/418. Geochem Geophys Geosyst 4. http://dx.doi.org/10.1029/2002GC000414

Peucker-Ehrenbrink B, Hanghoj K, Atwood T and Kelemen PB (2012) Rhenium-osmium isotope systematics and platinum group element concentrations in oceanic crust. Geology 40:199-202

Pitcher L, Helz RT, Walker RJ, Piccoli P (2009) Fractionation of the platinum-group elements and Re during crystallization of basalt in Kilauea Iki Lava Lake, Hawaii. Chem Geol 260:196-210

Plank T, Langmuir CH (1992) Effects of the melting regime on the composition of the oceanic crust. J Geophys Res 97:19749-19770

Prelević D, Jacob DE, Foley SF (2013) Recycling plus: a new recipe for the formation of AlpineHimalayan orogenic mantle lithosphere. Earth Planet Sci Lett 362:187-197

Prelević D, Brügmann G, Barth M, Božovic M, Cvetković V, Foley SF, Maksimović Z (2015) Osisotope constraints on the dynamics of orogenic mantle: The case of the Central Balkans. Gondwana Res 27:1560-1573

Price RC, Kennedy AK, Riggs-Sneerginger M, Frey FA (1986) Geochemistry of basalts from the Indian Ocean triple junction: implications for the generation and evolution of Indian Ocean ridge basalts. Earth Planet Sci Lett 78:379-396

Prinzhofer A, Lewin E, Allègre CJ (1989) Stochastic melting of the marble cake mantle: evidence from local study of the East Pacific Rise at 12"50'N. Earth Planet Sci Lett 92:189-206

Puchtel IS, Humayun M (2000) Platinum group elements in Kostomuksha komatiites and basalts: Implications for oceanic crust recycling and core-mantle interaction. Geochim Cosmochim Acta 64:4227-4242 
Puchtel IS, Humayun M (2001) Platinum group element fractionation in a komatiitic basalt lava lake. Geochim Cosmochim Acta 65:2979-2993

Puchtel IS, Brandon AD, Humayan M (2004) Precise Pt-Re-Os isotope systematics of the mantle from 2.7-Ga komatiites. Earth Planet Sci Lett 224:157-174

Puchtel IS, Brandon AD, Humayan M, Walker RJ (2005) Evidence for the early differentiation of the core from Pt/Re/Os isotope systematics of 2.8-Ga komatiites. Earth Planet Sci Lett 237:118-134

Puchtel IS, Walker RJ, Brandon AD, Nisbet EG (2009) Pt-Re-Os and Sm-Nd isotope and HSE and REE systematics of the 2.7 Ga Belingwe and Abitibi komatiites. Geochim Cosmochim Acta 73:6367-6389

Puffer JH (2001) Contrasting HFSE contents of plume sourced and reactivated arc-sourced continental flood basalts. Geology 29:675-678

Puffer JH (2003) A reactivated back-arc source for CAMP magma. In: Hames WE, McHone JG, Renne PR, Ruppel C (eds) The Central Atlantic Magmatic Province: Insights from Fragments of Pangea. Geophysical Monograph, Am Geophys Union 136:151-162

Putirka KD, Perfit M, Ryerson FJ, Jackson MG (2007) Ambient and excess mantle temperatures, olivine thermometry, and active vs. passive upwelling. Chem Geol 241:177-206

Rehkämper M, Hofmann AW (1997) Recycled ocean crust and sediment in Indian Ocean MORB. Earth Planet Sci Lett 147:93-106

Rehkämper M, Halliday AN, Fitton JG, Lee DC, Wieneke M, Arndt NT (1999) Ir, Ru, Pt, and Pd in basalts and komatiites: new constraints for the geochemical behaviour of the platinum-group elements in the mantle. Geochim Cosmochim Acta 63: 3915-3934

Reisberg L, Lorand J-P (1995) Longevity of sub-continental mantle lithosphere from osmium isotope systematics in orogenic peridotite massifs. Nature 376:159-162

Reisberg L, Allègre CJ, Luck J-M (1991) The Re-Os systematics of the Ronda ultramafic complex of Southern Spain. Earth Planet Sci Lett 105:196-213

Reisberg L, Zindler A, Marcantonio F, White W, Wyman D, Weaver B (1993) Os isotope systematics in ocean island basalts. Earth Planet Sci Lett 120:149-167

Reisberg L, Rouxel O, Ludden J, Staudigel H and Zimmermann C (2008) Re-Os results from ODP Site 801: Evidence for extensive Re uptake during alteration of oceanic crust. Chem Geol 248:256-271

Rhodes JM, Vollinger MJ (2005) Ferric/ferrous ratios in 1984 Mauna Loa lavas: a contribution to understanding the oxidation state of Hawaiian magmas. Contrib Mineral Petrol 149:666-674

Rhyzenko B, Kennedy GC (1973) The effect of pressure on the eutectic in the system Fe-FeS. Am J Sci 273:803-810

Riches AJV, Day JMD, Walker RJ, Simonetti A, Liu Y, Neal CR, Taylor LA (2012) Rheniumosmium isotope and highly siderophile element abundance systematics of angrite meteorites. Earth Planet Sci Lett 353-354:208-218

Righter K, Hauri EH (1998) Compatibility of Re in garnet during mantle melting and magma genesis. Science 280:1737-1741

Righter K, Chesley JT, Ruiz J (2002) Genesis of primitive arc basalt: constraints from $\mathrm{Re}$, Os and Cl on the depth of melting and role of fluids. Geology 30:619-622

Righter K, Campbell AJ, Humayun M, Hervig MRL (2004) Partitioning of Ru, Rh, Pd, Re, Ir, and Au between Cr-bearing spinel, olivine, pyroxene and silicate melts. Geochim Cosmochim Acta 68:867-880

Righter K, Humayun M, Danielson L (2008) Partitioning of palladium at high pressures and temperatures during core formation. Nat Geosci 1:321-323

Rocha-Júnior ERV, Puchtel IS, Marques LS, Walker RJ, Machado FB, Nardy AJR, Babinski M, Figueiredo AMG (2012) Re-Os isotope and highly siderophile element systematics of the Parana continental flood basalts (Brazil). Earth Planet Sci Lett 337-338:164-173 
Rogers NW, Davies MK, Parkinson IJ, Yirgu G (2010) Osmium isotopes and Fe/Mn ratios in Ti-rich picrites from the Ethiopian flood basalt province: no evidence for core contribution to the Afar plume. Earth Planet Sci Lett 296:413-422

Rosenthal A, Foley SF, Pearson DG, Nowell GM, Tappe S (2009) Petrogenesis of strongly alkaline primitive volcanic rocks at the propagating tip of the western branch of the East African Rift. Earth Planet Sci Lett 284:236-248

Roy-Barman M, Allègre CJ (1994) ${ }^{187} \mathrm{Oss}^{-186}$ Os ratios of mid-ocean ridge basalts and abyssal peridotites. Geochim Cosmochim Acta 58:5043-54

Roy-Barman M, Allègre CJ (1995) 187Os/186Os in oceanic island basalts: Tracing oceanic crust recycling in the mantle. Earth Planet Sci Lett 129:145-161

Roy-Barman M, Wasserburg GJ, Papanastassiou DA, Chaussidon M (1998) Osmium isotope composition and Re-Os concentrations in sulfide globules from basaltic glasses. Earth Planet Sci Lett 154:331-347

Rubin K (1997) Degassing of metals and metalloids from erupting seamount and midocean ridge volcanoes: observations and predictions. Geochim Cosmochim Acta 61:3525-3542

Rudnick RL, Fountain DM (1995) Nature and composition of the continental crust: a lower crustal perspective. Rev Geophys 33:267-309

Saal AE, Rudnick RL, Ravizza GE, Hart SR (1998) Re-Os isotope evidence for the composition, formation and age of the lower continental crust. Nature 393:58-61

Salters VJM, Stracke A (2004) Composition of the depleted mantle. Geochem Geophys Geosys 5. http://dx.doi.org/10.1029/2003GC000597

Schaefer BF, Parkinson IJ, Hawkesworth CJ (2000) Deep mantle plume osmium isotope signature from West Greenland Tertiary picrites. Earth Planet Sci Lett 175:105-118

Schaefer BF, Turner S, Parkinson I, Rogers N, Hawkesworth C (2002) Evidence for recycled Archaean oceanic mantle lithosphere in the Azores plume. Nature 420:304-307

Scherstén A, Elliott T, Hawkesworth CJ, Norman M (2004) Tungsten isotope evidence that mantle plumes contain no contribution from the Earth's core. Nature 427:234-237

Schiano P, Birck JL, Allègre CJ (1997) Osmium-strontium-neodymium-lead isotopic covariations in mid-ocean ridge basalt glasses and the heterogeneity of the upper mantle. Earth Planet Sci Lett 150:363-379

Schiano P, Burton KW, Dupré B, Birck JL, Guille G, Allègre CJ (2001) Correlated Os-Pb-Nd-Sr isotopes in the Austral-Cook chain basalts: the nature of mantle components in plume sources. Earth Planet Sci Lett 186:527-537

Schiano P, David K, Vlastelic I, Gannoun A, Klein M, Nauret F, Bonnand P (2012) Osmium isotope systematics of historical lavas from Piton de la Fournaise (Réunion Island, Indian Ocean). Contrib Mineral Petrol 164:805-820

Schwartz JJ, John BE, Cheadle MJ, Miranda EA, Grimes, CB, Wooden JL, Dick HJB (2005) Dating the growth of oceanic crust at a slow-spreading ridge. Science 310:654-657

Selo M, Storzer D (1979) Chrolnologie des événements volcaniques de la zone Famous. C R Acad Sci Paris 289:1125-1128

Sen IS, Bizimis M, Sen G, Huang S (2011) A radiogenic Os component in the oceanic lithosphere? Constraints from Hawaiian pyroxenite xenoliths. Geochim Cosmochim Acta 75:4899-4916

Sharma M, Chen C, Blazina T (2012) Osmium contamination of seawater samples stored in polyethylene bottles. Limnol Oceanogr Methods 10:618-630

Shimizu N (1998) The geochemistry of olivine-hosted melt inclusions in a FAMOUS basalt ALV519-4-1. Phys Earth Planet Inter 107:183-201

Shirey SB (1997) Re-Os isotopic composition of Mid-continent rift system picrites: implications for plume-lithosphere interaction and enriched mantle sources. Can J Earth Sci 34:489-503

Shirey SB, Walker RJ (1995) Carius tube digestion for low-blank Re-Os analyses. Anal Chem 67:2136-2141 
Shirey SB, Walker RJ (1998) The Re-Os isotope system in cosmochemistry and high-temperature geochemistry. Ann Rev Earth Planet Sci 26:423-500

Sigurdsson H, Schilling JG (1976) Spinels in Mid-Atlantic Ridge basalts: Chemistry and occurrence. Earth Planet Sci Lett 29:7-20

Skovgaard AC, Storey M, Baker J, Blusztajn J, Hart SR (2001) Osmium-oxygen isotope evidence for a recycled and strongly depleted component in the Icelandic mantle plume. Earth Planet Sci Lett 194:259-275

Smith HJ, Spivak AJ, Staudigel H, Hart SR (1995) The boron isotopic composition of altered oceanic crust. Chem Geol 126:119-135

Snow JE, Reisberg L (1995) Os isotopic systematics of the MORB mantle: results from altered abyssal peridotites. Earth Planet Sci Lett 133:411-421

Sobolev AV, Hofmann AW, Kuzmin DV, Yaxley GM, Arndt NT, Chung SL, Danyushevsky LV, Elliott T, Frey FA, Garcia MO, Gurenko AA, Kamenetsky VS, Kerr AC, Krivolutskaya NA, Matvienkov VV, Nikogosian IK, Rocholl A, Sigurdsson IA, Sushchevskaya NM, Teklay M (2007) The amount of recycled crust in sources of mantle-derived melts. Science 316:412-417

Spera FJ, Bohrson WA (2001) Energy-constrained open-system magmatic processes I: General model and energy-constrained assimilation and fractional crystallization (EC-AFC) formulation. J Petrol 42:999-1018.

Spivak AJ, Edmond JM (1987) Boron isotope exchange between seawater and the oceanic crust. Geochim Cosmochim Acta 51:1033-1043

Standish JJ, Hart SR, Blusztajn J, Dick HJB, Lee KL (2002) Abyssal peridotite osmium isotopic compositions from Cr-spinel. Geochem Geophys Geosyst 3. http://dx.doi.org/10.1029/2001GC000161

Su Y, Langmuir CH (2003) Global MORB chemistry compilation at the segment scale. Ph.D. thesis, Department of Earth and Environmental Sciences, Columbia University. http://petdb.ldeo.columbia.edu/documentation/morbcompilation/

Sun Y, Ying J, Zhou X, Shao J, Chu Z, Su B (2014) Geochemistry of ultrapotassic volcanic rocks in Xiaogulihe NE China: Implications for the role of ancient subducted sediments. Lithos 208209:53-66

Suzuki K, Senda R, Shimizu K (2011) Osmium behavior in a subduction system elucidated from chromian spinel in Bonin Island beach sands. Geology 39:999-1002

Tatsumoto M (1966) Genetic relations of oceanic basalts as indicated by lead isotopes. Science 153:1094-1101

Tejada MLG, Suzuki K, Hanyu T, Mahoney JJ, Ishikawa A, Tatsumi Y, Chang Q, Nakai S (2013) Cryptic lower crustal signature in the source of the Ontong Java Plateau revealed by Os and Hf isotopes. Earth Planet Sci Lett 377-378:84-96

Tejada MLG, Hanyu T, Ishikawa A, Senda R, Suzuki K, Fitton G, Williams R (2015) Re-Os isotope and platinum group elements of a FOcal ZOne mantle source, Louisville Seamounts Chain, Pacific ocean. Geochem Geophys Geosys 16:486-504 doi:10.1002/2014GC005629

Thompson RN, Ottley CJ, Smith PM, Pearson DG, Dickin AP, Morrison MA, Leat PT, Gibson SA (2005) Source of the quaternary alkalic basalts, picrites, and basanites of the Potrillo volcanic field, New Mexico, USA: lithospheric or convecting mantle? J Petrol 46: 1603-1643

Toutain JP, Meyer G (1989) Iridium-bearing sublimates at hot-spot volcano (Piton de la Fournaise, Indian Ocean). Geophys Res Lett 16:1391-1394

Tredoux M, Lindsay NM, Davies G, McDonald I (1995) The fractionation of platinum group elements in magmatic systems, with the suggestion of a novel causation mechanism. S Afr J Geol 98:157-167

Turner S, Handler M, Bindeman I, Suzuki K (2009) New insights into the origin of O-Hf-Os isotope signatures in arc lavas from Tonga-Kermadec. Chem Geol 266:187-193 
van Acken D, Becker H, Walker RJ,McDonough WF, Wombacher F, Ash RD, Piccoli PM (2010) Formation of pyroxenite layers in the Totalp ultramafic massif (Swiss Alps) - insights from highly siderophile elements and Os isotopes. Geochim Cosmochim Acta 74: 661-683

Van Orman JA, Keshav S, Fei Y (2008) High pressure solid-metal/liquid-metal partitioning of Os, Re and Pt in the Fe/S system. Earth Planet Sci Lett 274:250-257

Verati C, Bertrand H, Feraraud G (2005) The farthest record of the Central Atlantic Magmatic Province into West Africa craton: Precise ${ }^{40} \mathrm{Ar} /{ }^{39} \mathrm{Ar}$ dating and geochemistry of Taoudenni basin intrusives (northern Mali). Earth Planet Sci Lett 235:391-407

Vidal P, Clauer N (1981) Pb and Sr isotopic systematics of some basalts and sulfides from the East Pacific Rise at 21'N (project RITA). Earth Planet Sci Lett 55:237-246

Vils F, Tonarini S, Kalt A, Seitz H-M (2009) Boron, lithium and strontium isotopes as tracers of seawater-serpentinite interaction at Mid-Atlantic ridge, ODP Leg 209. Earth Planet Sci Lett 286:414-425

Vogel DC, Keays RR (1997) The application of platinum group geochemistry in constraining the source of basalt magmas: results from the Newer Volcanic Province, Victoria, Australia. Chem Geol 136:181-204

Volkening J, Walczyk T, Heumann KG (1991). Osmium isotope ratio determinations by negative thermal ionization mass spectrometry. Int J Mass Spectrom Ion Proc 105:147-159

Walczyk T, Hebeda EH, Heumann KG (1991) Osmium isotope ratio measurements by negative thermal ionization mass spectrometry (NTI-MS) improvement in precision and enhancement in emission by introducing oxygen or freons into the ion source. Fresenius' J Anal Chem 341:537541

Walker RJ (2009) Highly siderophile elements in the Earth, Moon and Mars: update and implications for planetary accretion and differentiation. Chemie der Erde - Geochem 69:101-125

Walker RJ, Fassett JD (1986) Isotopic measurement of sub-nanogram quantities of rhenium and osmium by resonance ionization mass spectrometry. Anal Chem 58:2923-2927

Walker RJ, Carlson RW, Shirey SB, Boyd FR (1989) Os, Sr, Nd, and Pb isotope systematics of Southern African peridotite xenoliths; implications for the chemical evolution of subcontinental mantle. Geochim Cosmochim Acta 53:1583-95

Walker RJ, Morgan JW, Beary E, Smoliar MI, Czamanske GK, Horan MF (1997) Applications of the 190Pt-1860s isotope system to geochemistry and cosmochemistry. Geochim Cosmochim Acta 61:4799-4808

Walker RJ, Storey M, Kerr AC, Tarney J, Arndt NT (1999) Implications of 187Os isotopic heterogeneities in a mantle plume: evidence from Gorgona Island and Curaçao. Geochim Cosmochim Acta 63:713-728

Wallace P, Carmichael ISE (1992) Sulfur in basaltic magmas. Geochim Cosmochim Acta 56:18631874

Wang BD, Chen JL, Xu JF, Wang LQ (2014) Geochemical and Sr-Nd-Pb-Os isotopic compositions of Miocene ultrapotassic rocks in southern Tibet: Petrogenesis and implications for the regional tectonic history. Lithos 208-209:237-250

Warren JM, Shirey SB (2012) Lead and osmium isotopic constraints on the oceanic mantle from single abyssal peridotite sulfides. Earth Planet Sci Lett 359-360:279-293

Watson EB, Ben Othman D, Luck JM, Hofmann AW (1987) Partitioning of U, Pb, Cs, Yb, Hf, Re and Os between chromian diopsidic pyroxene and haplobasaltic liquid. Chem Geol 62:191-208

Watson EB, Baker DR (1985) Chemical diffusion in magmas: an overview of experimental results and geochemical applications. Adv Phys Geochim 9:120-151

White R, McKenzie D (1989) Magmatism at rift zones: the generation of volcanic continental margins and flood basalts. J Geophys Res 94:7685-7729

White WM (2010) Oceanic island basalts and mantle plumes: the geochemical perspective. Annu Rev Earth Planet Sci 38:133-160 
White WM, Schilling JG (1978) The nature and origin of geochemical variation in Mid-Atlantic Ridge basalts from the Central North Atlantic. Geochim Cosmochim Acta 42:1501-1516 A 244:484-496

Widom E, Shirey SB (1996) Os isotope systematics in the Azores: implications for mantle plume sources. Earth Planet Sci Lett 142:451-465

Widom E, Hoernle KA, Shirey SB, Schmincke H-U (1999) Os isotope systematics in the Canary Islands and Madiera: lithospheric contamination and mantle plume signatures. J Petrol 40:279296

Widom E, Kepezhinskas P, Defant M (2003) The nature of metasomatism in the sub-arc mantle wedge: evidence from Re-Os isotopes in Kamchatka peridotite xenoliths. Chem Geol 196:282306

Wilson JT (1963) A possible origin of the Hawaiian Islands. Can J Phys 41:863-870

Wilson M (1997) Thermal evolution of the Central Atlantic passive margins: continental break-up above a Mesozoic superplume. J Geol Soc, London 154:491-495

Wilson AH, Shirey SB, Carlson RW (2003) Archaean ultra-depleted Komatiites formed by hydrous melting of cratonic mantle. Nature 423:858-860

Woodhead JD, McCulloch MT (1998) Ancient seafloor signals in Pitcairn Island lavas and evidence for large amplitude, small length-scale mantle heterogeneities Earth and Planetary Science Letters 94(3-4):257-273

Woodhead J, Brauns M (2004) Current limitations to the understanding of Re-Os behaviour in subduction systems, with an example from New Britain. Earth Planet Sci Lett 221:309-323

Woodland SJ (2000) Development of ICP MS isotope dilution preconcentration techniques for determination of platinum group elements in volcanic rocks. $\mathrm{PhD}$ thesis University of Durham

Woodland SJ, Pearson DG, Thirlwall MF (2002) A platinum group element and Re-Os isotope investigation of siderophile element recycling in subduction zones: comparison of Grenada, Lesser Antilles Arc, and the Izu-Bonin arc. J Petrol 43:171-198

Workman RK, Hart SR, Jackson MG, Regelous M, Farley KA, Blusztajn J, Kurz M (2004) Recycled metasomatised lithosphere as the origin of the Enriched Mantle II (EM2) end-member: evidence from the Samoan Volcanic Chain. Geochem Geophys Geosys 5:Q04008 http://dx.doi.org/10.1029/2003GC000623

Workman RK, Hart SR (2005) Major and trace element composition of the depleted MORB mantle (DMM). Earth Planet Sci Lett 231:53-72

Wright E, White WM (1987) The origin of Samoa: new evidence from $\mathrm{Sr}, \mathrm{Nd}$ and $\mathrm{Pb}$ isotopes. Earth Planet Sci Lett 81:151-162

$\mathrm{Xu} \mathrm{JF}$, Suzuki K, Xu YG, Mei HJ, Li J (2007) Os, Pb, and Nd isotope geochemistry of the Permian Emeishan continental flood basalts: insights into the source of a large igneous province. Geochim Cosmochim Acta 71:2104-2119

Yang AY, Zhao TP, Zhou MF, Deng XG, Wange GQ, Li J (2013) Os isotopic compositions of MORBs from the ultra-slow spreading Southwest Indian Ridge: Constraints on the assimilation and fractional crystallization (AFC) processes. Lithos 179:28-35

Yang AY, Zhou MF, Zhao TP, Deng XG, Qi L, Xu JF (2014) Chalcophile elemental compositions of MORBs from the ultraslow-spreading Southwest Indian Ridge and controls of lithospheric structure on S-saturated differentiation. Chem Geol 382:1-13

Yaxley GM (2000) Experimental study of the phase and melting relations of homogeneous basalt + peridotite mixtures and implications for the petrogenesis of flood basalts. Contrib Mineral Petrol139:326-338

Yaxley GM, Green DH (1998) Reactions between eclogite and peridotite: mantle refertilization by subducted oceanic crust. Schweizerische Mineralogische und Petrographische Mitteilungen $78: 243-25$ 
Yokoyama T, Walker D, Walker RJ (2009) Low osmium solubility in silicate at high pressures and temperatures. Earth Planet Sci Lett 279:165-173

You CF, Spivack AJ, Gieskes JM, Martin JB, Davisson ML (1996) Boron contents and isotopic compositions in pore waters: a new approach to determine temperature induced artefactsgeochemical implications. Mar Geol 129:351-361

Yudovskaya MA, Tessalini S, Distler VV, Chaplygin IV, Chugaev AV, Dikov YP (2008) Behaviour of highly siderophile elements during magma degassing: a case study at the Kudryavy volcano. Chem Geol 248:318-341

Zhang M, Suddaby P, O'Reilly SY, Norman M, Qiu J (2000) Nature of the lithospheric mantle beneath the eastern part of the Central Asian fold belt: mantle xenolith evidence. Tectonophysics 328:131-156

Zhang YL, Liu CZ, Ge WC, Wu FY, Chu ZY (2011) Ancient sub-continental lithospheric mantle (SCLM) beneath the eastern part of the Central Asian Orogenic Belt (CAOB): implications for crust-mantle decoupling. Lithos 126:233-247

Zhang Z, Zhi X, Chen L, Saunders AD, Reichow MK (2008) Re-Os isotopic compositions of picrites from the Emeishan flood basalt province, China. Earth and Planetary Science Letters 276:30-39

Zindler A, Staudigel H, Batiza R (1984) Isotope and trace element geochemistry of young Pacific seamounts: implications for the scale of upper mantle heterogeneity. Earth Planet Sci Lett 70:175-195

Zindler A, Hart SR (1986) Chemical geodynamics. Chemical geodynamics. Ann Rev Earth Planet Sci 14:493-571 
Figure 1. CI-chondrite normalised PGE abundances in (a) mantle derived melts and (b) primitif upper mantle and residual mantle rocks. Due to extraction of the low melting temperature $\mathrm{Cu}-\mathrm{Ni}$ sulfide melt, which concentrates Pt and Pd, the PGE patterns of residual mantle rocks are depleted in $\mathrm{Re}, \mathrm{Pd}$ and Pt. The depletion factor increases with the degree of melting (10 to 40\%), and therefore with the amount of magma extracted from the mantle column, due to the concentration of the PGE in monosulfide solid solution (mss) and also to the fact that an increase in the degree of melting decreases the amount of mss remaining in the residual mantle. Mantle derived rocks show the opposite behaviour. MORB are IPGE depleted ( $\mathrm{Ru}, \mathrm{Ir}$, Os) relative to the mantle composition because base-metal sulfides are not exhausted. In contrast the very high degree of partial melting $(>35 \%)$ needed to generate the archean komatiite melts consumed all the base-metal sulfides in the mantle, generating PGE pattern close to the mantle. Data sources: MORB (Gannoun et al., 2007; Burton et al., 2015; Bézos et al., 2005; Yang et al., 2013; 2014; Jenner et al., 2012; Rehkämper et al., 1999); Komatiites (Connolly et al., 2011; Puchtel et al;, 2004; 2005; 2009); Abyssal peridotites(Harvey et al., 2006; Luguet et al., 2007; Pearson et al., 2004; Reisberg and Lorand, 1995); Primitif mantle (Becker et al., 2006).

Figure 2. Highly siderophile elements concentrations, normalised to CI-chondrite (Lodders et al., 2009). Primitive Earth mantle composition are from Becker et al. (2006) and from McDonough and Sun (1995). Predicted composition of Earth's mantle as a result of metal-silicate partitioning at low pressure (1 atm) are from Borisov et al. (1994; 1995); Borisov and Plame (1997); Fortenfant et al. (2003; 2006); Ertel et al. (1999); Ertel et al. (2001) and at high pressure (20 GPa) are from Brenan \& McDonough (2009); Cottrell and Walker (2006); Ertel et al. (2006); Holzheid et al. (2000); Righter et al. (2008); Ohtani and Yurimoto (1996). The Late veneer addition are using the average composition of all chondrite groups (Walker, 2009).

Figure 3. Summary of sulfide/silicate partition coefficients determined by experiment (Andrews and Brenan, 2002; Brenan, 2008; Crocket et al., 1997; Fleet et al., 1996; Mungall and Brenan, 2014) and from natural samples (Gannoun et al., 2004; 2007; Hart end Ravizza, 1996; Patten et al., 2013; Peach et al., 1990; Roy Barman et al., 1998)

Figure 4. Mineral-melt partition coefficients of HSE determined by experiment (Brenan et al., 2003; 2005; 2012; Chazey and Neal, 2005;Mallman and O'Neill, 2007; Righter et al., 2004) and from natural samples (Burton et al., 1999; 2000; 2002; Connolly et al., 2011; Debaille et al., 2009; Gannoun et al., 2004; Gao et al., 2008; Hart and Ravizza; 1996; Harvey et al., 2010; 2011; Jackson end Shirey, 2011; Puchtel and Humayun, 2001; Puchtel et al., 2009).

Figure 5. CI-chondrite-normalized PGE patterns for refractory mantle sulfides and intrergranular $\mathrm{Cu}$ rich sulfides. Reported patterns are a combination of different peridotites (Alard et al., 2000; 2005; Harvey et al., 2006; Lorand et al., 2001). Calculated mixture of residual included sulfide and an appropriate amount of intergranular sulfides produces a primitive mantle-like PGE pattern.

Figure 6. CI-chondrite normalized PGE abundances for Os-Ir-Ru alloys from ophiolite chromitites (Augé, 1985; 1988; González-Jiménez et al., 2009; 2011; Nakagawa and Franco, 1997). 
Figure 7. PGE vs. Ni plots of MORBs. The high-F (mostly MORBs from Kolbeinsey Ridge) and low-F fields represent MORB suites produced by high and low degrees of partial melting defined by Bézos et al. (2005). Data sources: Jenner et al., 2012; Yang et al., 2014.

Figure 8. Rhenium (pg. $\mathrm{g}^{-1}$ ) against osmium (pg. $\left.\mathrm{g}^{-1}\right)$ for terrestrial basalts. Literature data are from the following references: MORB (Burton et al., 2015; Escrig et al., 2004; Gannoun et al., 2007; Schiano et al., 1997; Yang et al., 2013). OIB (Class et al., 2009; Day et al., 2009; 2010b; Hauri and Hart, 1993; Ireland et al., 2009; 2011; Jackson et al., 2011; Schiano et al., 2001; Widom and Shirey, 1996); Arc lavas (Alves et al., 2002; Chesley et al;, 2002); Komatiites (Connolly et al., 2011; Puchtel et al; 2004; 2005; 2009); Mantle rocks (Harvey et al., 2006; Pearson et al., 2004; Reisberg and Lorand, 1995); CI-chondrite (Becker et al., 2006).

Figure 9. Re/Os ratio versus Os concentrations for terrestrial basalts. Data are frome the same references as for Figure 8

Figure 10. Rhenium concentrations (pg. $\mathrm{g}^{-1}$ ) in MORB glass shown against (a) Aluminium (wt. \% $\left.\mathrm{Al}_{2} \mathrm{O}_{3}\right)$ and (b) sulfur $\left(\mu \mathrm{g} \cdot \mathrm{g}^{-1}\right)$. Plotted data for MORB are from the same references as in Figure 8.

Figure 11. Osmium concentrations (pg.g $\left.{ }^{-1}\right)$ in MORB glass shown against Nickel $\left(\mu \mathrm{g} \cdot \mathrm{g}^{-1}\right)$. Plotted data for MORB are from the same references as in Figure 8.

Figure 12. ${ }^{187} \mathrm{Os} /{ }^{188} \mathrm{Os}$ versus $1 /{ }^{188} \mathrm{Os}$ ratios for MORB glasses. There is no covariation between Os concentration and Os isotope composition, and hence no evidence for binary mixing (see text for discussion). Plotted data are from Burton et al., 2015; Gannoun et al., 2004; 2007; Yang et al., 2013.

Figure 13. ${ }^{187} \mathrm{Re}^{187} \mathrm{Os}$ isotope evolution diagram for MORB glasses. No covariation is observed between ${ }^{187} \mathrm{Re} /{ }^{188}$ Os and ${ }^{187} \mathrm{Os} /{ }^{188} \mathrm{Os}$. MORB glass possesses high ${ }^{187} \mathrm{Re} /{ }^{187} \mathrm{Os}$ (parent/daughter) ratios which raises the possibility that radiogenic ${ }^{187}$ Os could be produced in very short periods of time (Gannoun et al., 2004; 2007). However, those samples with the highest ${ }^{187} \mathrm{Re} /{ }^{187}$ Os $(>2000)$ possess ${ }^{187} \mathrm{Os} /{ }^{188}$ Os compositions close to the value expected for the primitive upper mantle.

Figure 14. ${ }^{187} \mathrm{Os} /{ }^{188} \mathrm{Os}$ isotope composition of MORB glasses (Burton et al., 2015; Gannoun et al., 2004; 2007; Yang et al., 2013) shown against (a) ${ }^{87} \mathrm{Sr} /{ }^{86} \mathrm{Sr}$ (b) ${ }^{143} \mathrm{Nd} /{ }^{144} \mathrm{Nd}$ and (c) ${ }^{206} \mathrm{~Pb} /{ }^{204} \mathrm{~Pb}$ (see text for discussion) (Sr, $\mathrm{Nd}$ and $\mathrm{Pb}$ data from Dosso et al., 1993; Escrig et al., 2004; Hamelin and Allègre, 1985; Hamelin et al., 1984; 1986; Prinzhofer et al., 1989; Schiano et al., 1997; Vidal and Clauer, 1981).

Figure 15. ${ }^{187} \mathrm{Os} /{ }^{188} \mathrm{Os}$ isotope composition of MORB glass shown against (a) ridge depth (metres below sea level) and (b) spreading rate (cm/year) (calculated using Argus et al., 2011 and De Mets et 3000 al., 2010). 
Figure 16. Comparison of ${ }^{187} \mathrm{Os} /{ }^{188} \mathrm{Os}$ isotope ratios for $\mathrm{MORB}$ glass investigated previously (Schiano et al., 1997; Escrig et al., 2004) and re-analyzed in Gannoun et al. (2007) and Burton et al. (2015)

Figure 17. Osmium abundance shown against the deviation of the measured ${ }^{187} \mathrm{Os} /{ }^{188} \mathrm{Os}$ (in \%) between recent studies (Gannoun et al., 2007; Burton et al., 2015) and earlier work (Schiano et al., 1997; Escrig et al., 2004). The highest deviation in the reported ${ }^{187} \mathrm{Os} /{ }^{188} \mathrm{Os}$ is observed for the glass samples with the lowest Os contents.

Figure 18. ${ }^{187} \mathrm{Re}-{ }^{188} \mathrm{Os}$ isotope evolution diagram for coexisting phases from the olivine- basalt ARP1974-011-018 (Gannoun et al. 2004) . Olivine, plagioclase, glass, and matrix yield a best-fit line corresponding to an age of $565 \pm 336 \mathrm{ky}(2 \sigma)$. Clinopyroxene (not shown) does not lie on this best-fit line, suggesting either an older age or a different and more radiogenic source for this phase.

Figure 19. ${ }^{187} \mathrm{Re}-{ }^{188} \mathrm{Os}$ isotope evolution diagram for coexisting phases from the picritic basalt ARP1973-010-003 (Gannoun et al. 2004). Olivine, plagioclase, glass, and sulfide lie on a best-fit line corresponding to an age of $2.53 \pm 0.15 \mathrm{My}(2 \sigma)$. Spinel possesses a distinct isotope composition from this best-fit line and is probably the phase responsible for the displacement of the matrix from the same line.

Figure 20. ${ }^{187} \mathrm{Os} /{ }^{188} \mathrm{Os}$ vs $1 /[\mathrm{Os}]$ for heterogeneous Indian MORB. Two samples from the central indian ridge, MD57 D9-1 and D9-6 show high range of ${ }^{187} \mathrm{Os} /{ }^{188} \mathrm{Os}$ ratios from 0.126 to 0.254 which covaries with Os concentrations (Burton et al., 2015).

Figure 21. ${ }^{187} \mathrm{Os} /{ }^{188} \mathrm{Os}$ vs (a) $\mathrm{Cl}$ and (b) B for MORB glass

Figure 22. ${ }^{187} \mathrm{Os} /{ }^{188} \mathrm{Os}$ isotope composition of MORB glass shown against $\delta^{11} \mathrm{~B}$ ratios in the same sample (symbols as in Fig. 2) illustrating a clear positive covariation between both isotope systems. MORB samples with radiogenic ${ }^{187} \mathrm{Os} /{ }^{188} \mathrm{Os}$ values also possess high $\delta^{11} \mathrm{~B}$ ratios. Mixing curves between uncontaminated MORB $\left({ }^{187} \mathrm{Os} /{ }^{188} \mathrm{Os}\right.$ of 0.125 and $\delta^{11} \mathrm{~B}$ of $-10 \%$ with $7 \mathrm{pg} . \mathrm{g}^{-1}$ and $1 \mu \mathrm{g} . \mathrm{g}^{-1}$ for Os and B concentrations respectively) and other sources are also shown. (1) Direct contamination by seawater with ${ }^{187} \mathrm{Os} /{ }^{188} \mathrm{Os}$ of $1.06, \delta^{11} \mathrm{~B}$ of $+40 \%$, $[\mathrm{Os}]=0.01 \mathrm{pg} \cdot \mathrm{g}^{-1}$ and $[\mathrm{B}]=4.6 \mu \mathrm{g} . \mathrm{g}^{-1}$ (Levasseuret al., 1998). (2) Assimilation of Fe-Mn oxyhydroxides or Os-rich sediments. The grey field in the left of the graph encompasses the potential mixing lines ${ }^{187} \mathrm{Os} /{ }^{188} \mathrm{Os} \sim 1$, [Os] $=1 \mathrm{pg} \cdot \mathrm{g}^{-1}$, $\delta^{11} \mathrm{~B}=+10 \%$ and $[\mathrm{B}]=10 \mu \mathrm{g} \cdot \mathrm{g}^{-1}$. (3) Assimilation of relatively old altered oceanic crust with variable ${ }^{187} \mathrm{Os} /{ }^{188} \mathrm{Os}$ ratios $\left(0.15,0.20\right.$ and 0.25 for $\mathrm{a}, \mathrm{b}$ and $\mathrm{c}$, respectively), [Os] $=10 \mathrm{pg} \cdot \mathrm{g}^{-1},[\mathrm{~B}]=8 \mu \mathrm{g} \cdot \mathrm{g}^{-1}$ and $\delta^{11} \mathrm{~B}=+6 \%$. Marks on the curves denote the weight percentage of assimilated altered oceanic crust (in $1 \%$ increments) present in the mixture.

Figure 23. Backscattered-electron (BSE) images and chemical maps of typical MORB sulfides from the picritic basalt ARP1973-010-003 (Famous area, Mid-Atlantic ridge). Chemical maps were produced using a wavelength dispersive spectrometry (WDS) coupled to a CAMECA SX-100 
microprobe at Blaise Pascal University (Clermont-Ferrand, France). Shading indicates the relative abundance of a given element. MSS: monosulfide solid solution; ISS: intermediate solid solution; Pn: pentlandite. a. spherical sulfide globule inclusion in olivine. b. sulfide globule inclusion in basalt matrix. Both grains have coarse grained texture.

Figure 24. Bulk composition of sulfide droplets in the system $\mathrm{Fe}-\mathrm{Ni}-\mathrm{Cu}$ in weight fraction. The grey zone corresponds to the bulk composition of sulfide droplets from Czamanske \& Moore (1977). Dashed line represents the composition of sulfide liquid composition at Mss crystallization at 1100, 1050, and $1000{ }^{\circ} \mathrm{C}$ from Ebel \& Naldrett (1997). Note that texture of sulfide droplets is not dependent on their composition. Droplet liquidus range between more than 1100 to $1050{ }^{\circ} \mathrm{C}$. Modified from Czamanske and Moore (1977) and Patten et al. (2012).

Figure 25. ${ }^{187} \mathrm{Os} /{ }^{188} \mathrm{Os}$ isotope composition shown against Os concentration $\left(\mathrm{ng} \mathrm{g}^{-1}\right)$ for individual sulfides from MORB. This indicates a negative covariation between ${ }^{187} \mathrm{Os} /{ }^{188} \mathrm{Os}$ and Os concentration in the sulfides, where low Os sulfides possess more radiogenic Os isotope compositions. These radiogenic values may indicate that such sulfides are more susceptible to seawater derived contamination. Data taken from Burton et al., 2015; Gannoun et al., 2004; 2007; Roy Barman et al., 1998. (see text for discussion).

Figure 26. ${ }^{187} \mathrm{Os} /{ }^{188} \mathrm{Os}$ isotope composition of individual sulfides shown against the ${ }^{187} \mathrm{Os} /{ }^{188} \mathrm{Os}$ value of the glass host. In all cases, sulfide grains possess ${ }^{187} \mathrm{Os} /{ }^{188} \mathrm{Os}$ values that are less radiogenic than their glass host. Sulfides also show a much reduced range of Os isotope compositions compared to the corresponding host glass.

Figure 27. Histogram showing measured ${ }^{187} \mathrm{Os} /{ }^{188} \mathrm{Os}$ isotope ratios for (a) N-MORB glass data (Burton et al., 2015; Gannoun et al., 2004; 2007; Yang et al., 2013) (b) single grain sulfide data for MORB (Burton et al., 2015; Gannoun et al., 2004; 2007; unpublished data; Roy Barman et al., 1998) (c) abyssal peridotite whole-rock data (Alard et al., 2005; Brandon et al., 2000; Harvey et al., 2006; Martin, 1991; Snow and Reisberg, 1995; Standich et al., 2001) (d) single grain sulfide data for abyssal peridotites (Alard et al., 2005; Harvey et al., 2006; Warren and Shirey, 2012). The estimate for the primitive upper mantle (PUM; Meisel et al., 1996) is also shown. The average ${ }^{187} \mathrm{Os} /{ }^{188} \mathrm{Os}$ isotope composition of abyssal peridotites is $0.127 \pm 0.015(n=129)$ while individual sulfides yield an average ${ }^{187} \mathrm{Os} /{ }^{188}$ Os composition of $0.125 \pm 0.021(\mathrm{n}=63)$. N-MORB analysed thus far show no evidence for a subchondritic source which may reflect local melting of abyssal peridotites (Brandon et al., 2000), resistance of depleted peridotites to remelting (Hirth and Kohlstedt, 1996; Mange, 1996) or that Os from undepleted (fertile) mantle dominates the MORB budget.However, the high-Os (>20 $\left.\mathrm{ng} \mathrm{g}^{-1}\right)$ sulfides yield an average composition of $0.129 \pm 0.005(\mathrm{n}=31)$ close to the PUM estimation with values as low as 0.1236 . Therefore, these high-Os sulfides show no evidence no evidence for significant Re enrichment in the MORB source, as might be expected from the presence of recycled oceanic crust. Rather they indicate that the upper mantle source of these samples has experienced a long-term depletion of Re, similar to that observed in abyssal peridotites, and consistent with the incompatible nature of this element during mantle melting.

Figure 28. CI-chondrite normalised PGE abundance (Lodders et al., 2009). Open squares: average Deep Sea Drilling Project (DSDP) Sites 417/418; diamends: DSDP Hole 504B (Peucker-Ehrenbrink 
et al., 2003); solid squares: Ocean Drilling Program Hole 735B (Blusztajn et al., 2000); open circles: Oman crustal section (Peucker-Ehrenbrink et al., 2012); solid circles: composite ocean crust (Peucker-Ehrenbrink et al., 2012). The pattern of average MORB (This chapter) and abyssal peridotites (Harvey et al., 2006; Luguet et al., 2007; Pearson et al., 2004; Reisberg and Lorand, 1995) are added for comparison.

Figure 29. Plot of Os concentration versus Os isotope ratios for Louiville Seamount Chain basalts (age-corrected) and olivines (present-day). Pacific ocean island basalts (OIB), mid-ocean ridge basalts (MORB), and Ontong Java Plateau basalts (OJP) basalts are shown for comparison. Osmium abundances and isotopic signatures are limited compared to other Pacific OIB. Data sources: Schiano et al. (1997, 2001); Brandon et al. (1999); Eisele et al. (2002); Jackson and Shirey (2011); Hanyu et al. (2011); Tejada et al. (2013). Modified after Tejada et al. (2015).

Figure 30. ${ }^{187} \mathrm{Os} /{ }^{188} \mathrm{Os}$ versus (a) ${ }^{206} \mathrm{~Pb} /{ }^{204} \mathrm{~Pb}$ and (b) ${ }^{143} \mathrm{Nd} /{ }^{144} \mathrm{Nd}$ diagrams for Cameroon Volcanic Line (CVL) basalts. $\mathrm{Pb}$ and Nd isotope data are from Barfod (1999) and Lee et al. (1996). HIMU, DMM, EM1, and BSE are shown for reference. The average ${ }^{187} \mathrm{Os} /{ }^{188} \mathrm{Os}$ ratio for sub-continental lithospheric mantle is from Shirey and Walker (1998). Ultramafic xenoliths beneath the continental part of the CVL are also shown. The increments in the curves are $2 \%$. The grey shaded area indicates the possible compositions for crustally contaminated lavas. The most radiogenic samples from the continental sector can be explained by assimilation of 8 to $16 \%$ of continental crust. Assuming for the uncontaminated starting point [Os] $=10 \mathrm{pg} \mathrm{g}-1,{ }^{187} \mathrm{Os} /{ }^{188} \mathrm{Os}=0.156,{ }^{206} \mathrm{~Pb} /{ }^{204} \mathrm{~Pb}=20.24,[\mathrm{~Pb}]=2 \mu \mathrm{g}$ $\mathrm{g}^{-1}$; for upper continental crust (UCC) $[\mathrm{Os}]=50 \mathrm{pg} \mathrm{g}^{-1},{ }^{187} \mathrm{Os} /{ }^{188} \mathrm{Os}=1.4,{ }^{206} \mathrm{~Pb} /{ }^{204} \mathrm{~Pb}=19.3,[\mathrm{~Pb}]=8$ $\mu \mathrm{g} \mathrm{g}-1$; and for lower continental crust (LCC) $[\mathrm{Os}]=50 \mathrm{pg} \mathrm{g}^{-1},{ }^{187} \mathrm{Os} /{ }^{188} \mathrm{Os}=0.8$ (Saal et al., 1998), ${ }^{206} \mathrm{~Pb} /{ }^{204} \mathrm{~Pb}=17.5,[\mathrm{~Pb}]=8 \mu \mathrm{g} \mathrm{g}{ }^{-1}$. Curves (1) and (2) describe the possible mixing trajectories between HIMU and DMM. (1) Assimilation of mantle xenocrysts and (2) mixing of lavas derived from DMM and HIMU sources. Modelling parameters are as follows: for (1) DMM mantle [Os] = 3 $\mathrm{ng} \mathrm{g}{ }^{-1},{ }^{187} \mathrm{Os} /{ }^{188} \mathrm{Os}=0.125,{ }^{206} \mathrm{~Pb} /{ }^{204} \mathrm{~Pb}=18.5,[\mathrm{~Pb}]=0.15 \mu \mathrm{g} \mathrm{g}^{-1}$ and for (2) DMM melt $[\mathrm{Os}]=8 \mathrm{pg}$ $\mathrm{g}^{-1},{ }^{187} \mathrm{Os} /{ }^{188} \mathrm{Os}=0.127,{ }^{206} \mathrm{~Pb} /{ }^{204} \mathrm{~Pb}=18.5,[\mathrm{~Pb}]=0.45 \mu \mathrm{g} \mathrm{g}{ }^{-1}$. For Os-Nd modelling the starting point was chosen to be the closest to HIMU endmember, ${ }^{143} \mathrm{Nd} /{ }^{144} \mathrm{Nd}=0.513$, $[\mathrm{Nd}]=40 \mu \mathrm{g} g-1$, $187 \mathrm{Os} / 188 \mathrm{Os}=0.15,[\mathrm{Os}]=10 \mathrm{pg} \mathrm{g}^{-1}$; for $\mathrm{UCC}{ }^{143} \mathrm{Nd} /{ }^{144} \mathrm{Nd}=0.512,[\mathrm{Nd}]=27 \mu \mathrm{g} \mathrm{g}^{-1}$ (Rudnick and Fountain, 1995), ${ }^{187} \mathrm{Os} /{ }^{188} \mathrm{Os}=1.4$, [Os] $=50 \mathrm{pg} \mathrm{g}^{-1}$; and for $\mathrm{LCC}{ }^{143} \mathrm{Nd} /{ }^{144} \mathrm{Nd}=0.512,[\mathrm{Nd}]=50 \mu \mathrm{g}$ $\mathrm{g}^{-1}$ (Kwékam et al., 2013), ${ }^{187} \mathrm{Os} /{ }^{188} \mathrm{Os}=0.8$, [Os] $=30 \mathrm{pg} \mathrm{g}^{-1}$ (Saal et al., 1998). Reproduced with permission of Elsevier BV from Gannoun A, Burton KW, Barfod DN, Schiano P, Vlastélic I, Halliday AN (2015a) Resolving mantle and magmatic processes in basalts from the Cameroon volcanic line using the Re-Os isotope system. Lithos 224-225:1-12.

Figure 31. HSE patterns for $1.27 \mathrm{Ga}$ Coppermine CFB, $\sim 130 \mathrm{Ma}$ Parana basalts and $\sim 61 \mathrm{Ma}$ West Greenland picrites versus fractional crystallization models (grey-lines from 13 wt.\% MgO, highest HSE concentrations to $4 \mathrm{wt} . \% \mathrm{MgO}$, lowest HSE concentrations) assuming an 'average' West Greenland picrite composition for model starting composition. Explanation of the model is provided in detail in Day et al. (2013). Data sources are: Woodland (2000), Rocha-Junior et al. (2012) and Day et al. (2013). CI-chondrite normalization from Horan et al. (2003).

Figure 32. ${ }^{187} \mathrm{Os} /{ }^{188} \mathrm{Os}$ vs. 1/Os for the Wudalianchi-Erkeshan highly potassic basalts, NE China. The solid lines represent binary mixing lines modeled as follows: Fields of crust addition to the intraplate basalts of 2\%, 3.5\% and $8 \%$ lower continental crust are calculated using the values of Saal et al. $\left(1988 ;{ }^{187} \mathrm{Os} /{ }^{188} \mathrm{Os}=0.8\right.$ and Os concentration $\left.=49 \mathrm{pg} \mathrm{g}^{-1}\right)$. Metasomatic compositions are based upon mean values from Alard et al. (2002) and Sen et al. (2011). Mean primary sulfide compositions 
are taken from Alard et al. (2000, 2002), Pearson et al. (2002), Harvey et al. (2006, 2010, 2011), Lorand et al. (2013) - see also the supplementary information from Harvey et al. (2015, this volume). Modified after Chu et al. (2013).

Figure 33. World map showing locations of major convergent margin settings (stippled lines) and divergent boundary settings (grey lines) mentioned in the text.

Figure 34. Plots of $\mathrm{Os}$ and $\mathrm{Re}$ versus $\mathrm{MgO}$ content for convergent margin picrites, basalts and evolved rocks. Data sources: Brandon et al. (1996); Alves et al. (1999; 2002); Borg et al. (2000),

Figure 35. Plots of Os and reciprocal Os (1/Os) versus ${ }^{187} \mathrm{Os} /{ }^{188}$ Os for convergent margin picrites, basalts and evolved rocks. Data sources: Brandon et al. (1996); Alves et al. (1999; 2002); Borg et al. (2000), Woodland et al. (2002); Woodhead \& Brauns (2004); Turner et al. (2009); Bezard et al. (2015).

Figure 36. CI-chondrite normalized HSE diagrams for Lihir mantle xenoliths and lavas (McInnes et al., 1999), Grenada picrites and basalts and Izu-Bonin lavas (Woodland et al., 2000), and Kamchatka xenoliths (Widom et al., 2003). Note that PPGE > IPGE lavas from the Izu-Bonin and Grenada. CI chondrite normalization from Horan et al. (2003).

Figure 37. Assimilation accompanied by fractional crystallization (AFC) models of ${ }^{87} \mathrm{Sr} /{ }^{86} \mathrm{Sr}$ versus ${ }^{187} \mathrm{Os} /{ }^{188} \mathrm{Os}$ for Lesser Antilles primitive lavas Parameters for Models 1 and 2 are shown in the figure and in Table 3 of Bezard et al. (2015).

Figure 38. Primitive mantle normalized HSE diagram for cores and rinds of Mèlange metamorphic magic blocks from the Catalina Schist, Franciscan Complex and Samana Metamorphic Complex. Cores are consistent with dominantly reflecting basaltic/sedimentary protoliths with radiogenic Os and rinds are can represent as 70\% peridotite HSE contributions. Data are from Penniston-Dorland et al., 2012; 2014, with primitive mantle normalization from Becker et al. (2006). 
3201 Figure 1

3202
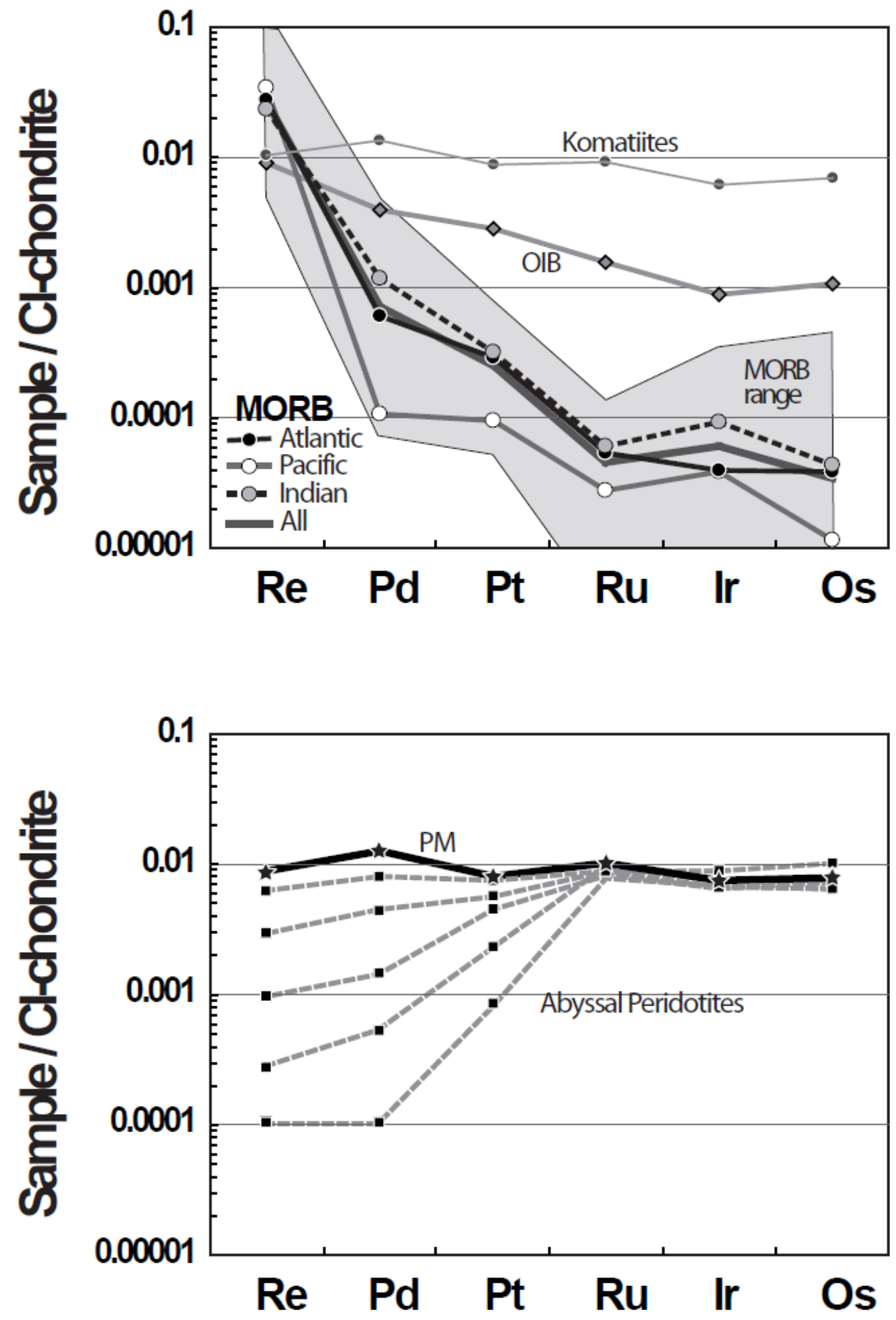


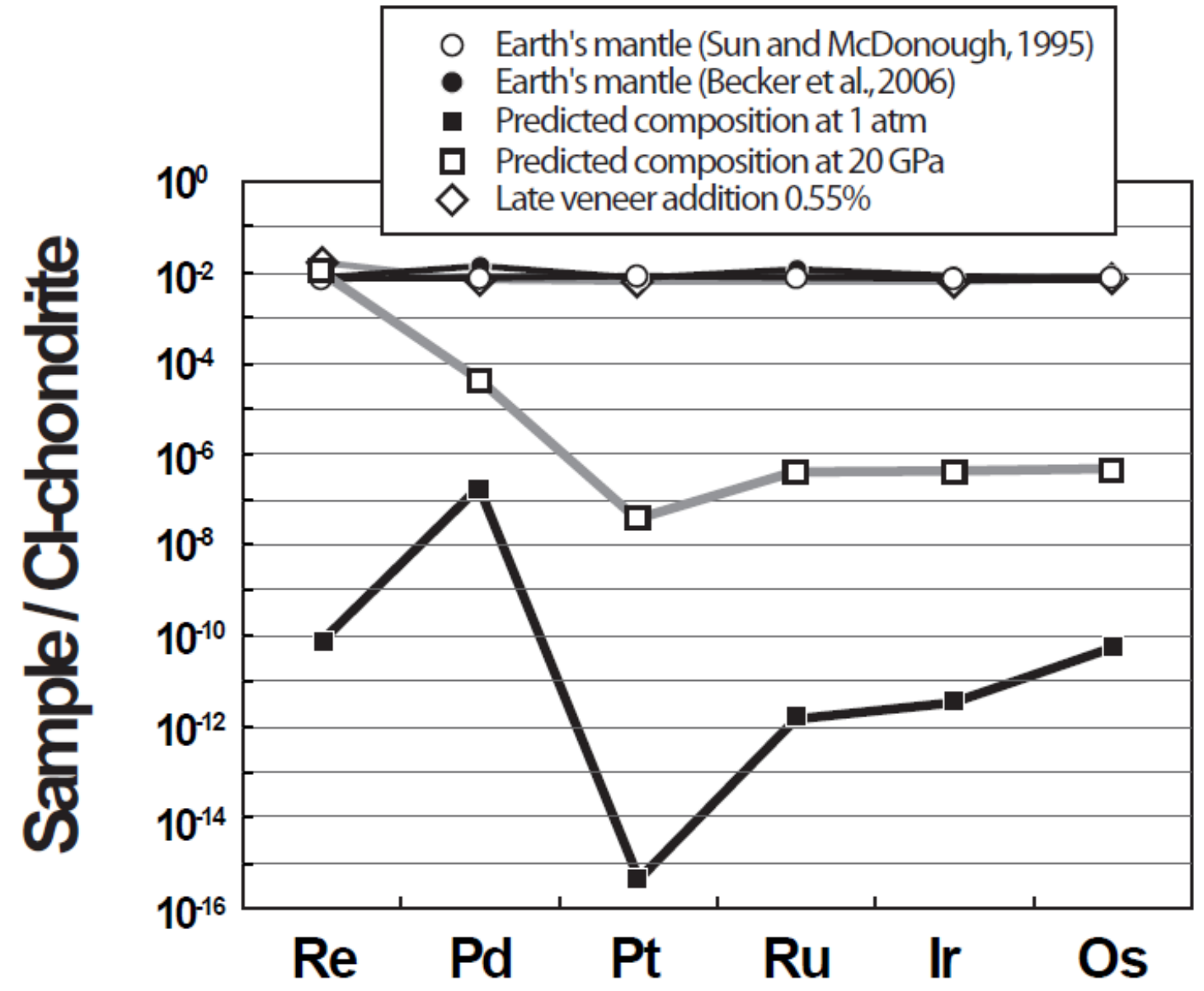




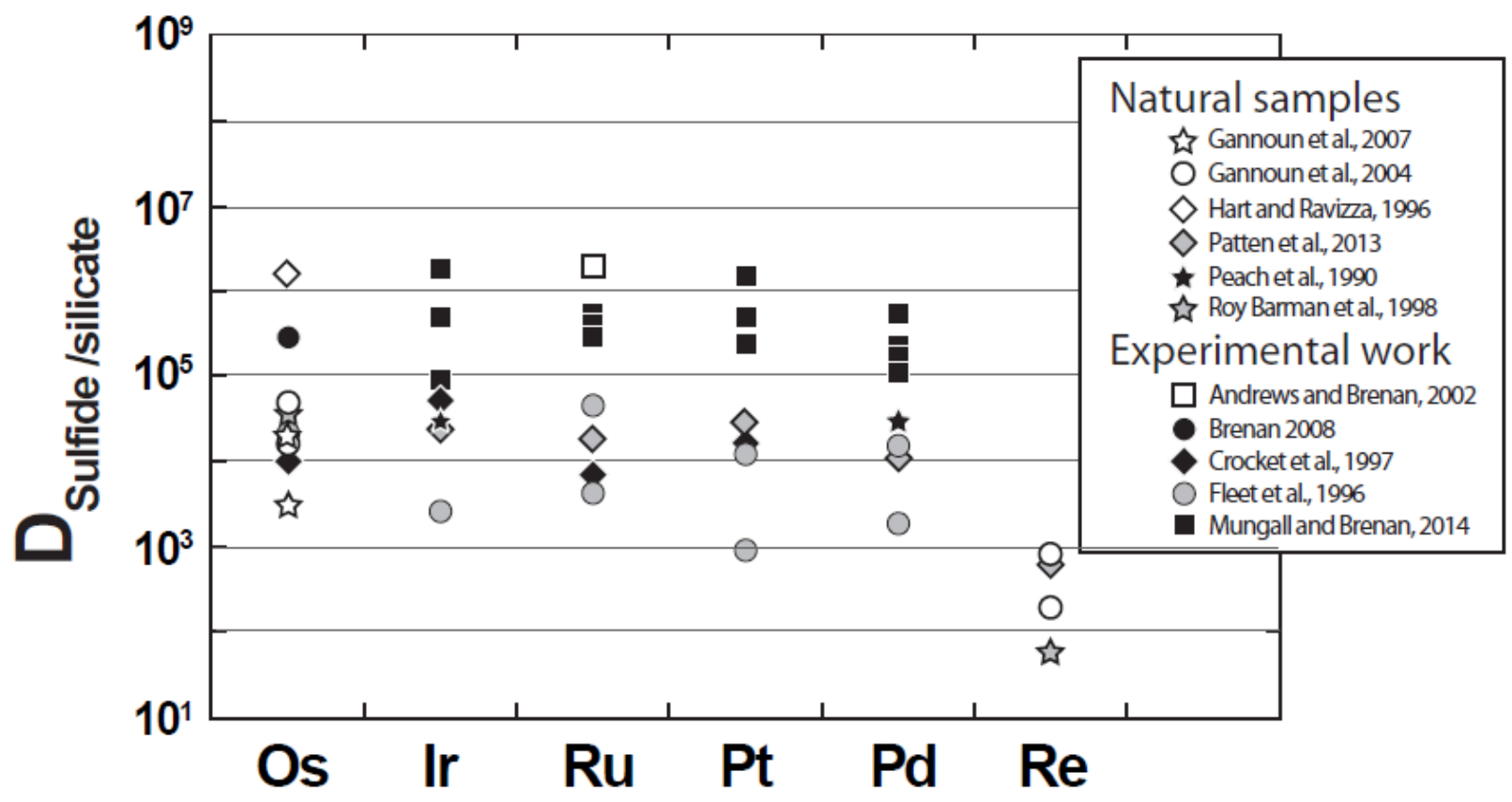


3261

3262

Figure 4
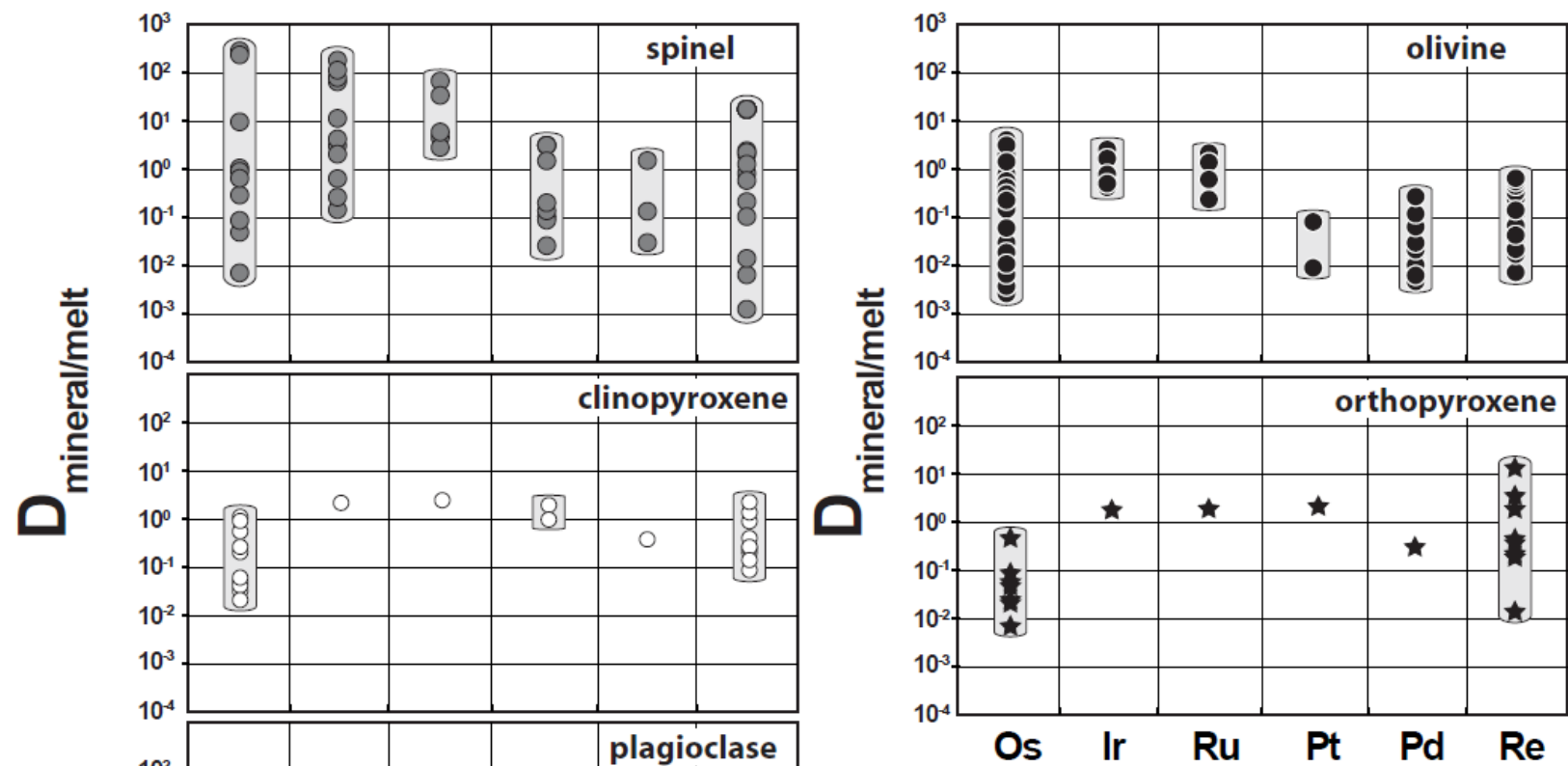

3263

3264

3265

3266

3267

3268

3269

3270

3271

3272

3273

3274

3275

3276

3277

3278

3279

3280

3281

3282

3283

3284

3285

3286 
Figure 5

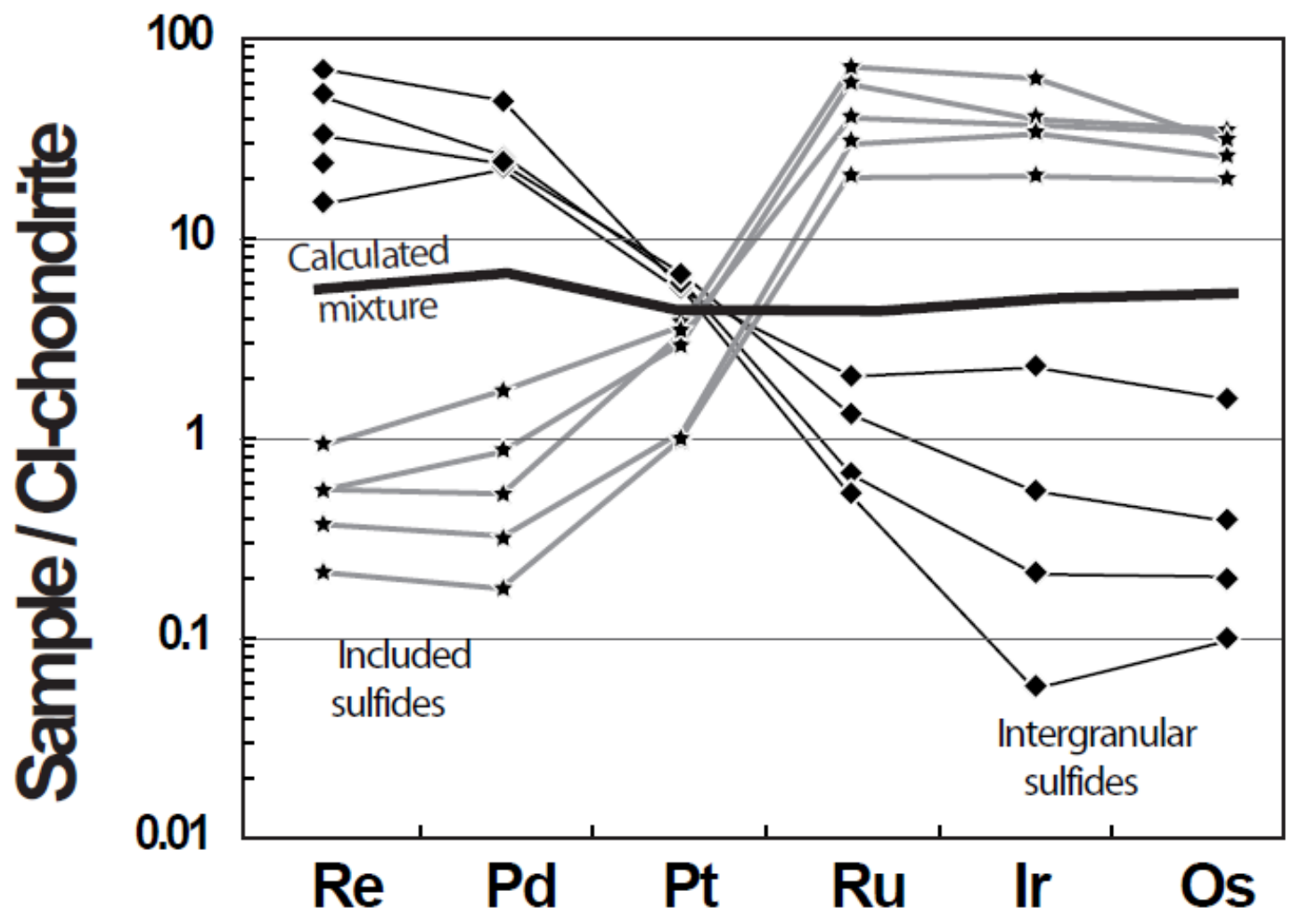


3313 Figure 6

3314

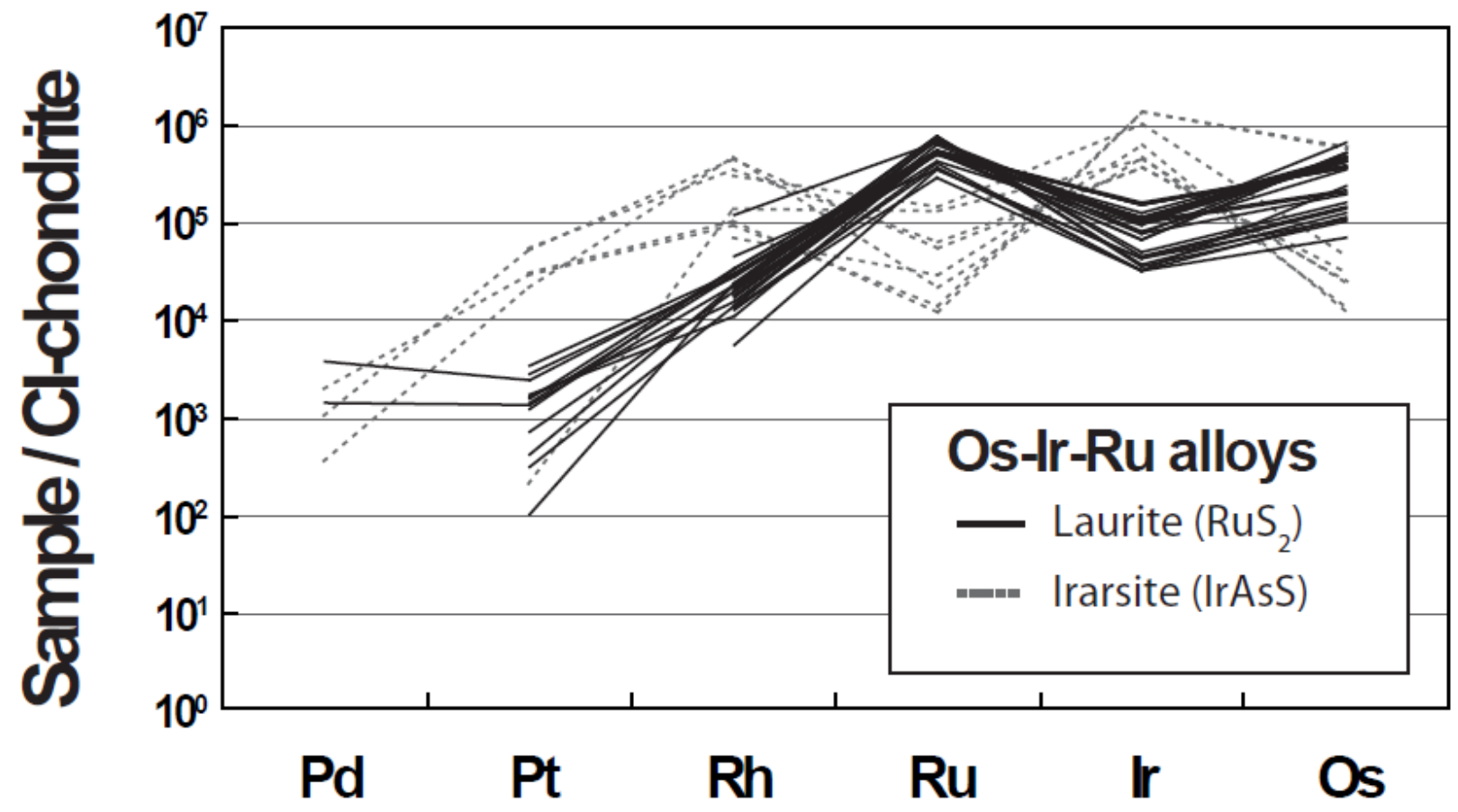

3315

3316

3317

3318

3319

3320

3321

3322

3323

3324

3325

3326

3327

3328

3329

3330

3331

3332

3333

3334

3335

3336

3337

3338

3339

3340

3341

3342 

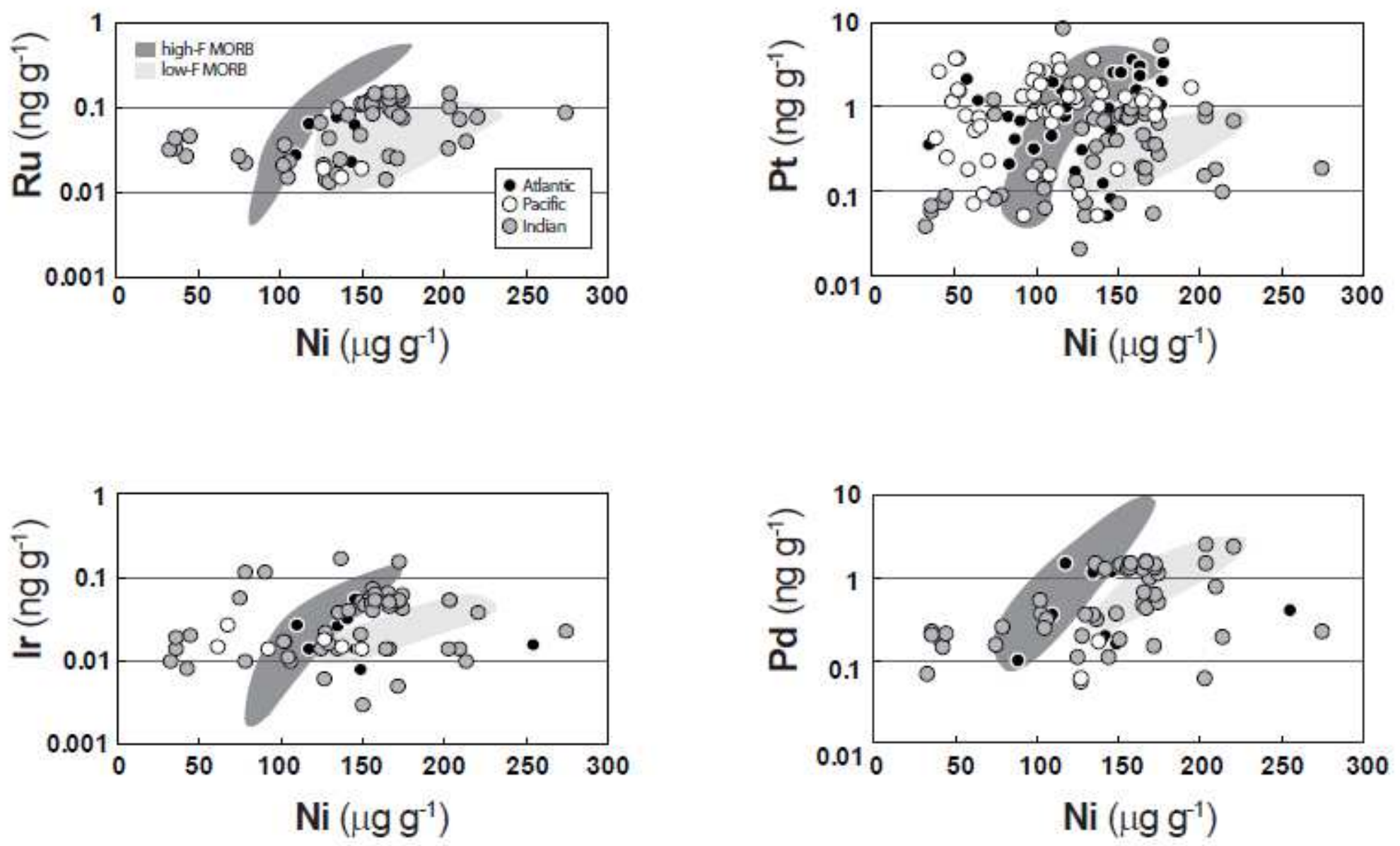


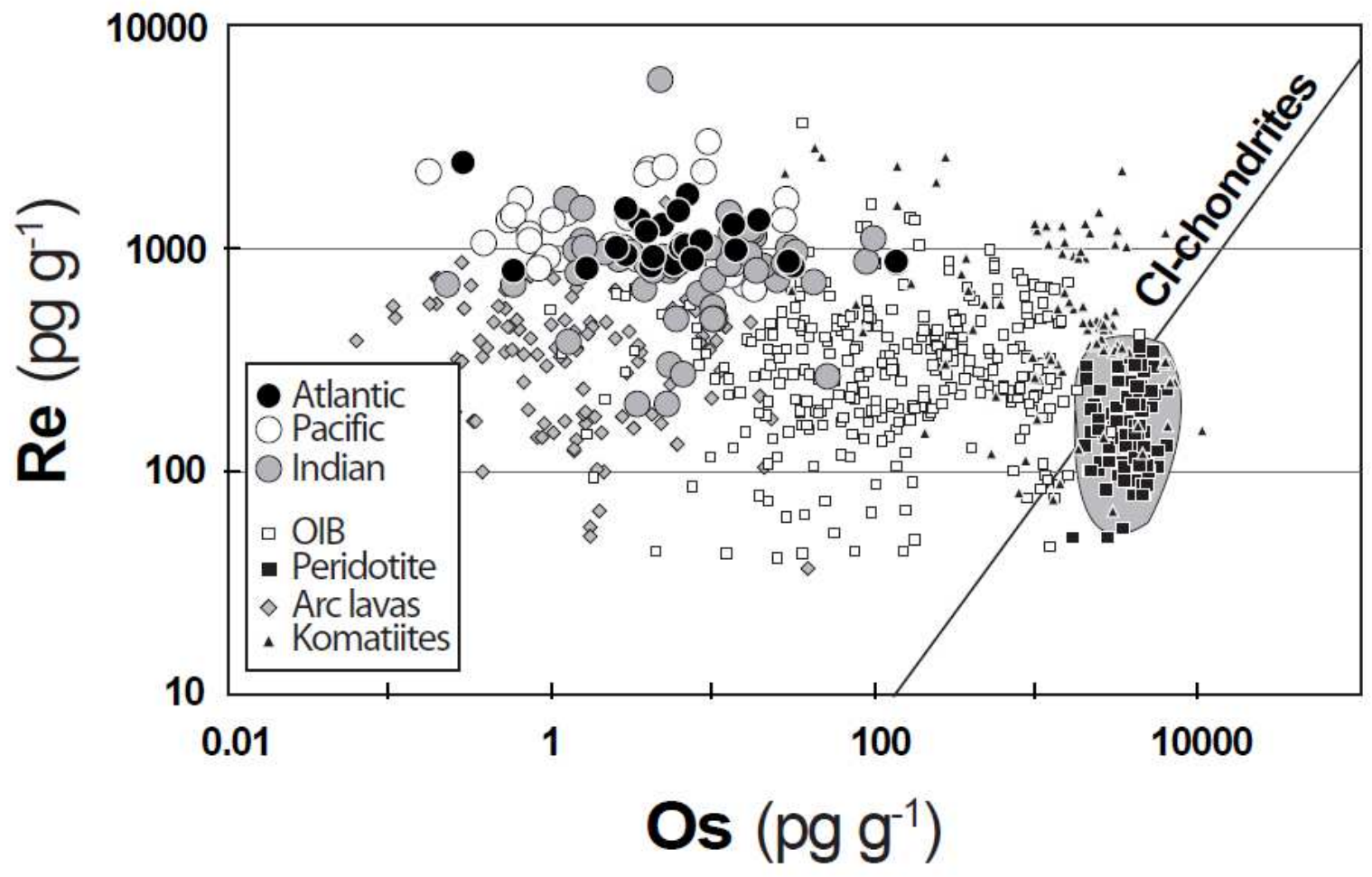


3376

3377

3378

3379

Figure 9

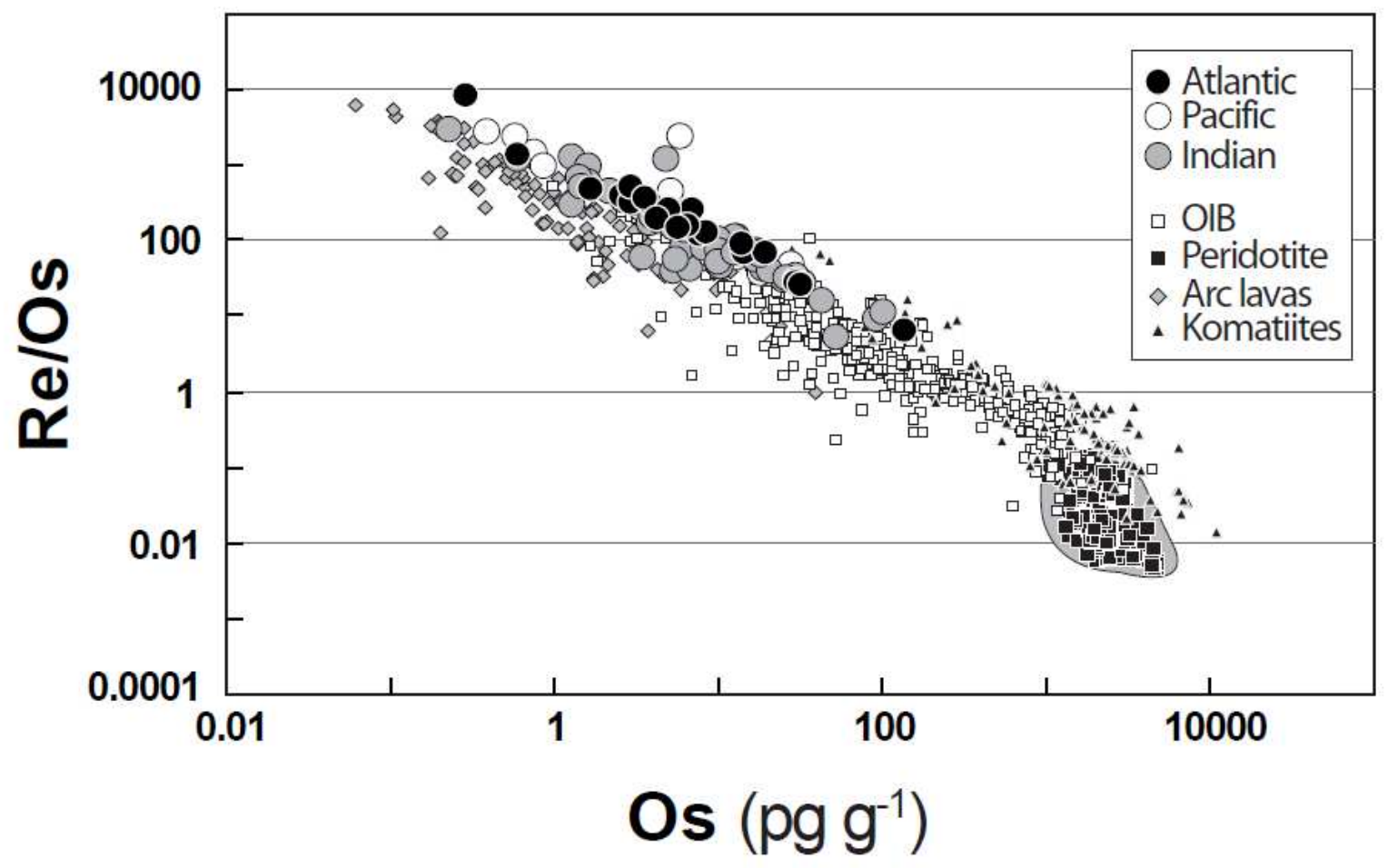

3380

3381

3382

3383

3384

3385

3386

3387

3388

3389

3390

3391

3392

3393

3394

3395

3396

3397

3398

3399

3400

3401

3402 
3403

3404
Figure 10
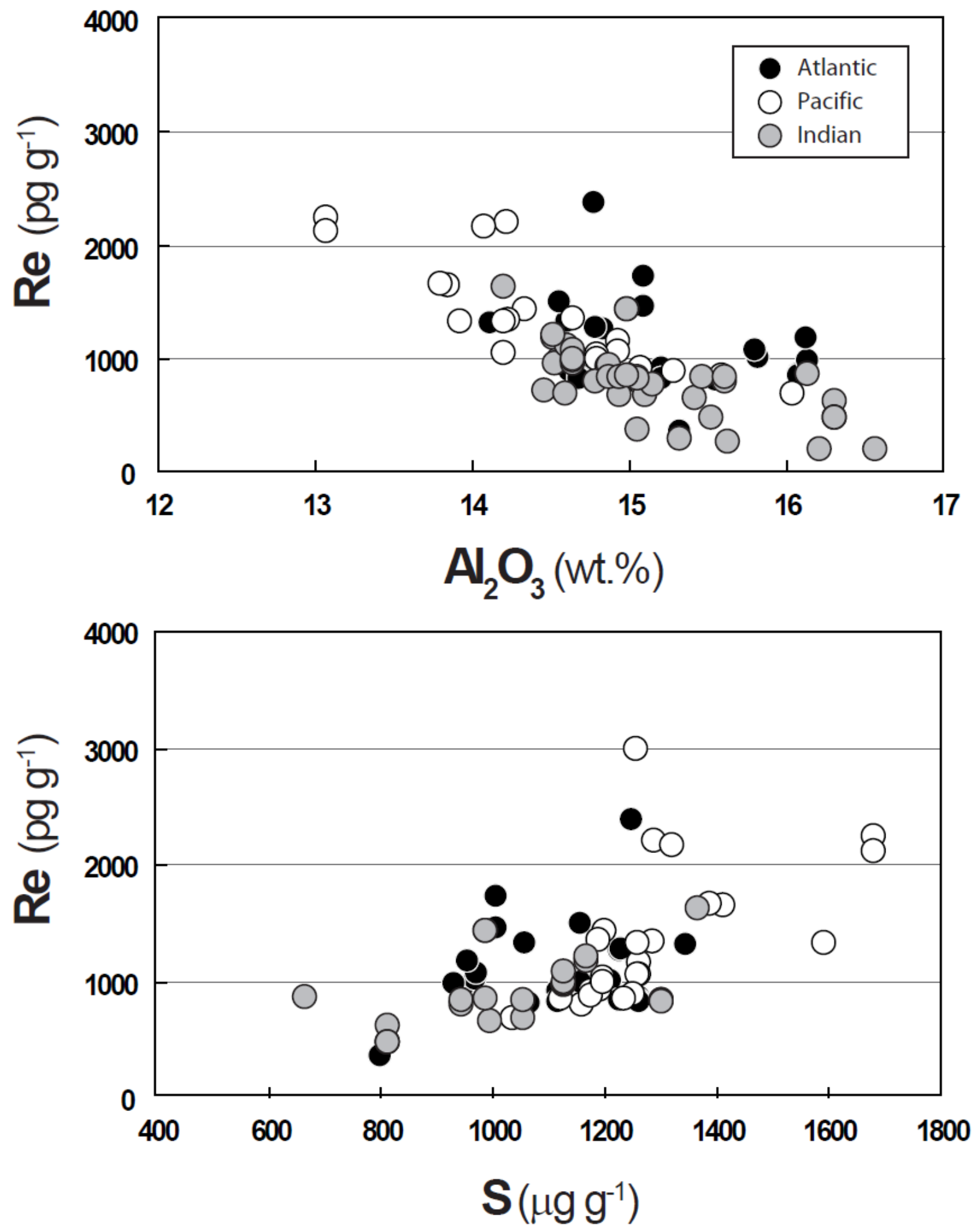
3410

3411

3412

3413

3414

3415

3416

3417

3418

3419

3420

3421

3422

3423

3424

3425

3426

3427

3428

3429

3430

3431

3432

3433

3434

3435

3436

3437

3438

Figure 11

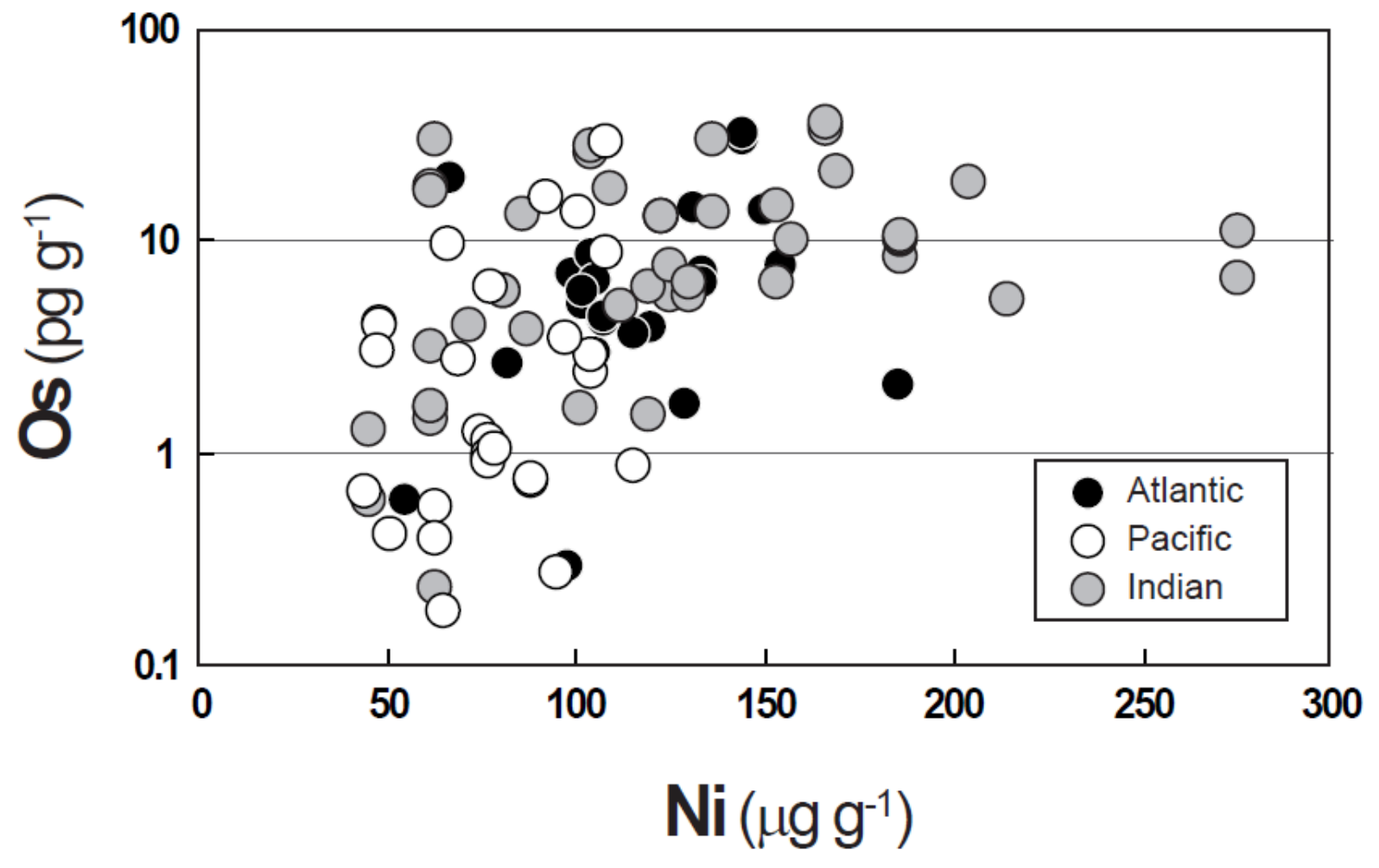


3439

3440
Figure 12

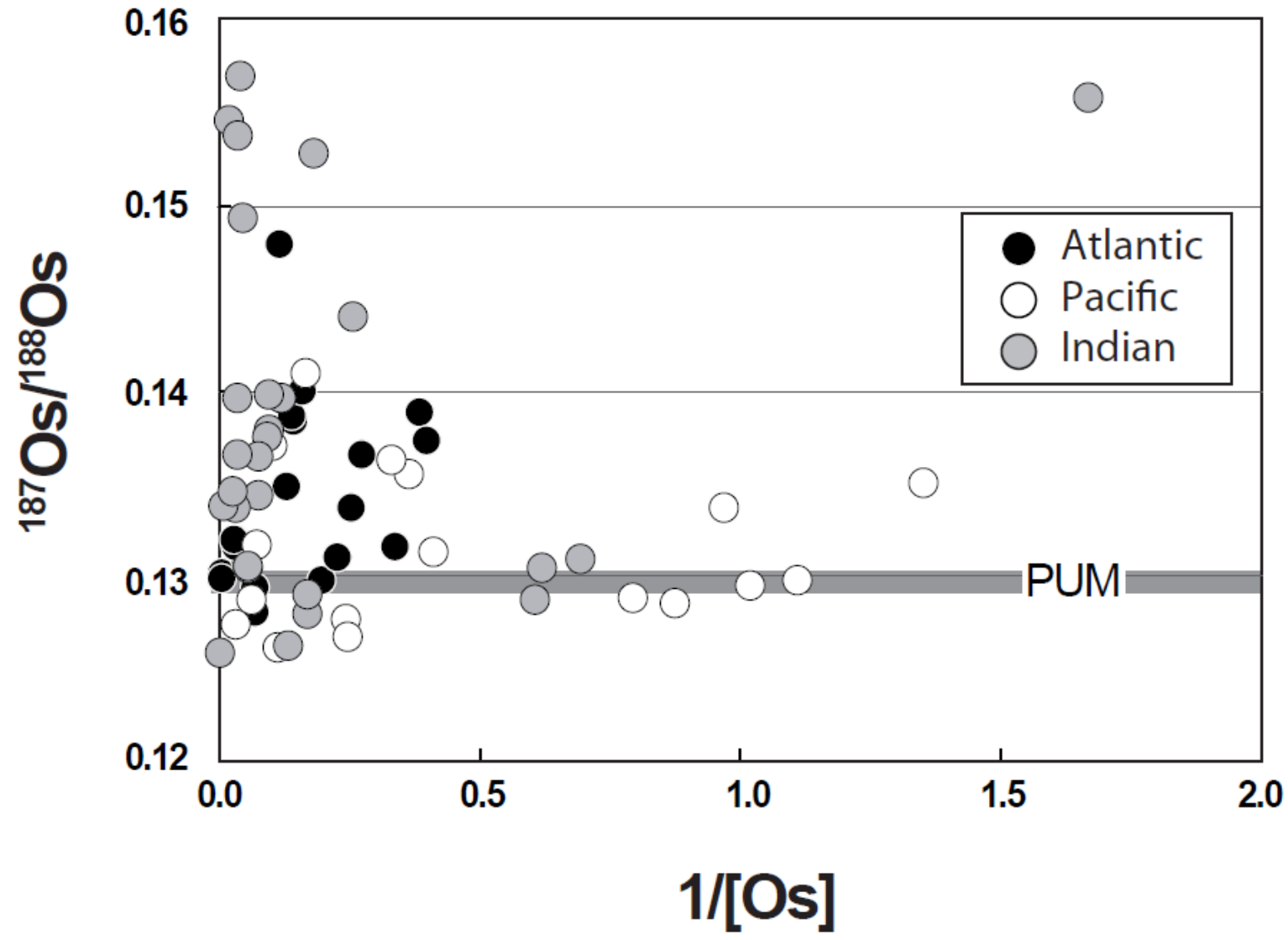

3441

3442

3443

3444

3445

3446

3447

3448

3449

3450

3451

3452

3453

3454

3455

3456

3457

3458

3459

3460

3461

3462

3463 
3464 3465

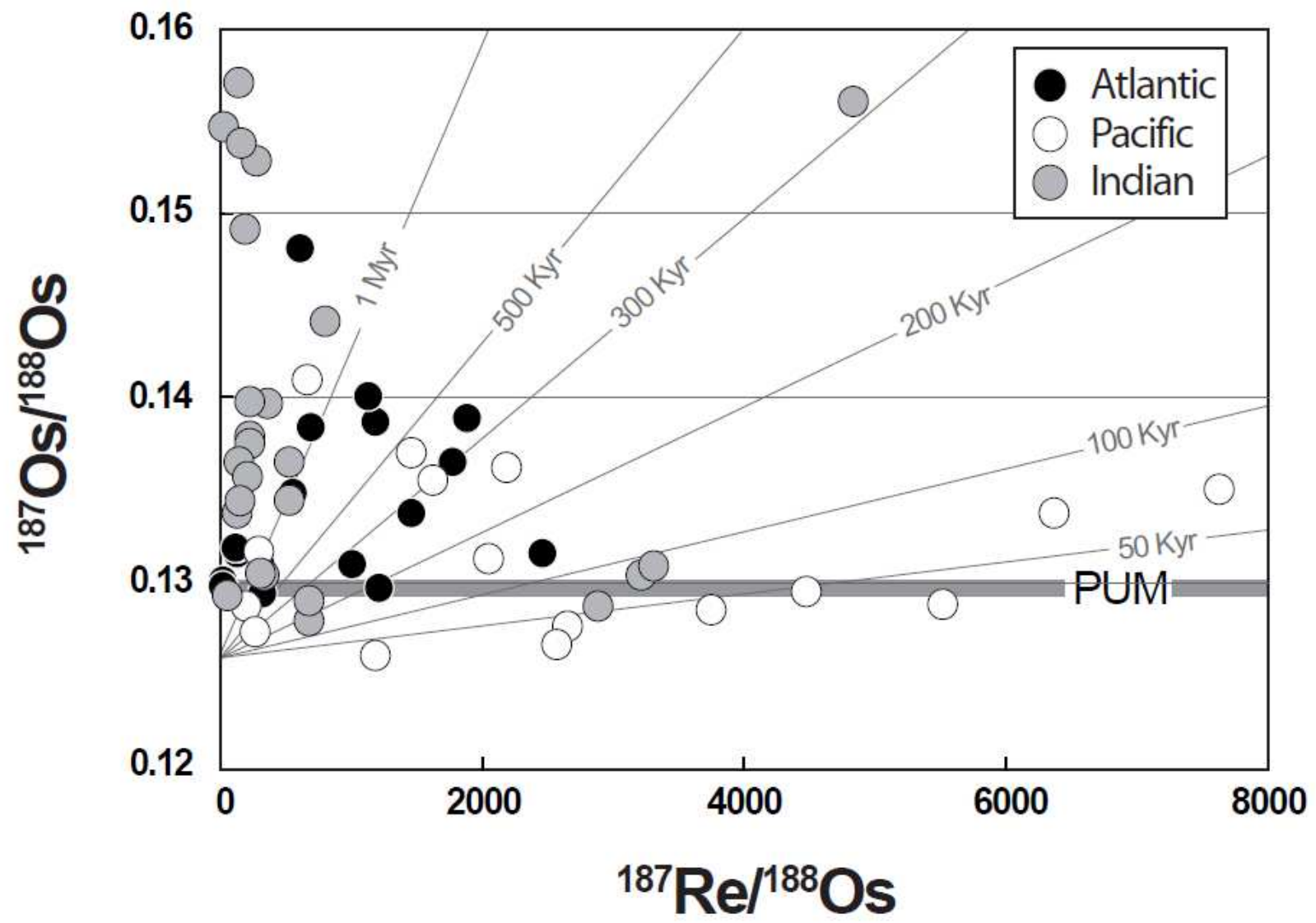



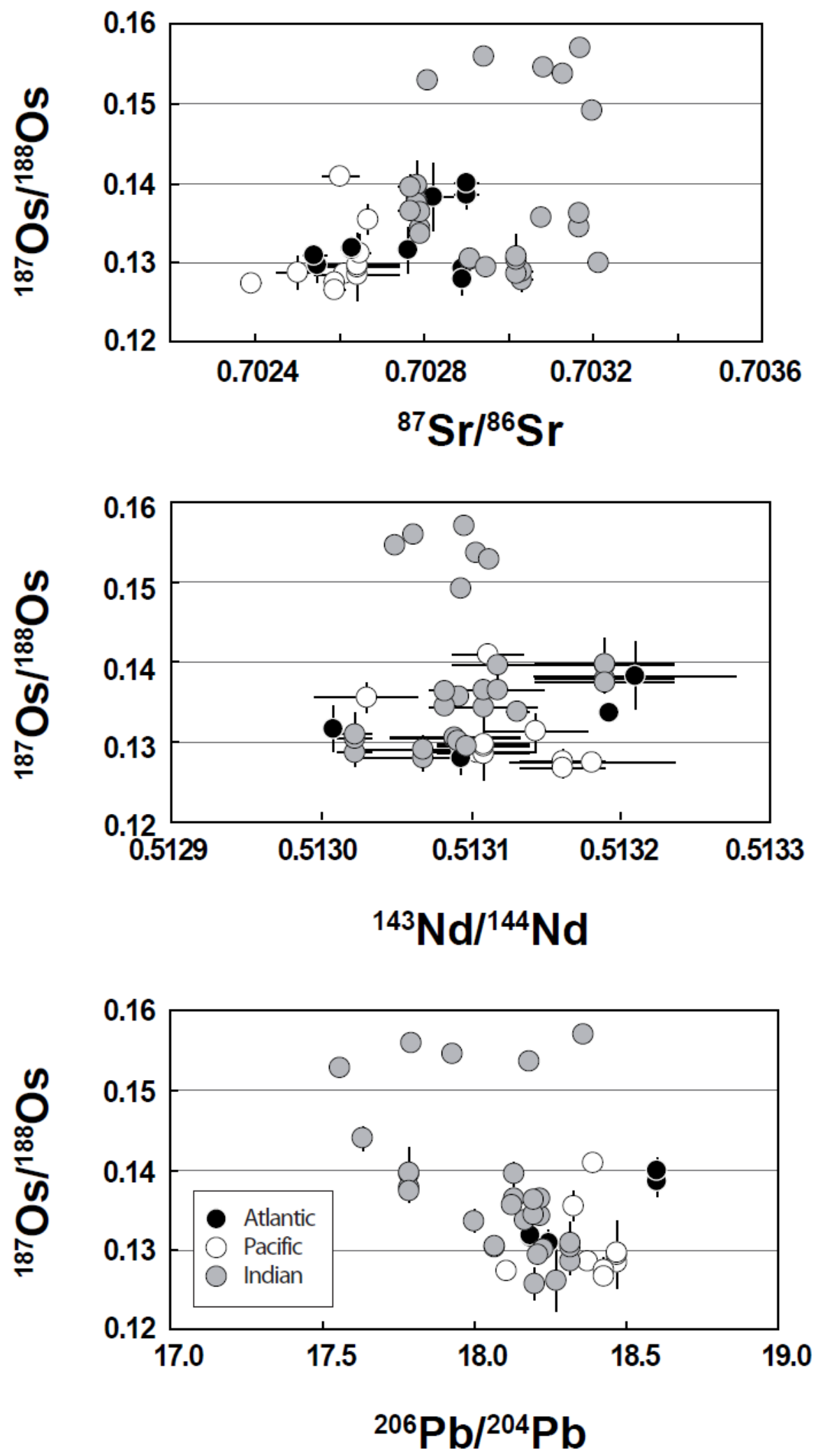
Figure 15

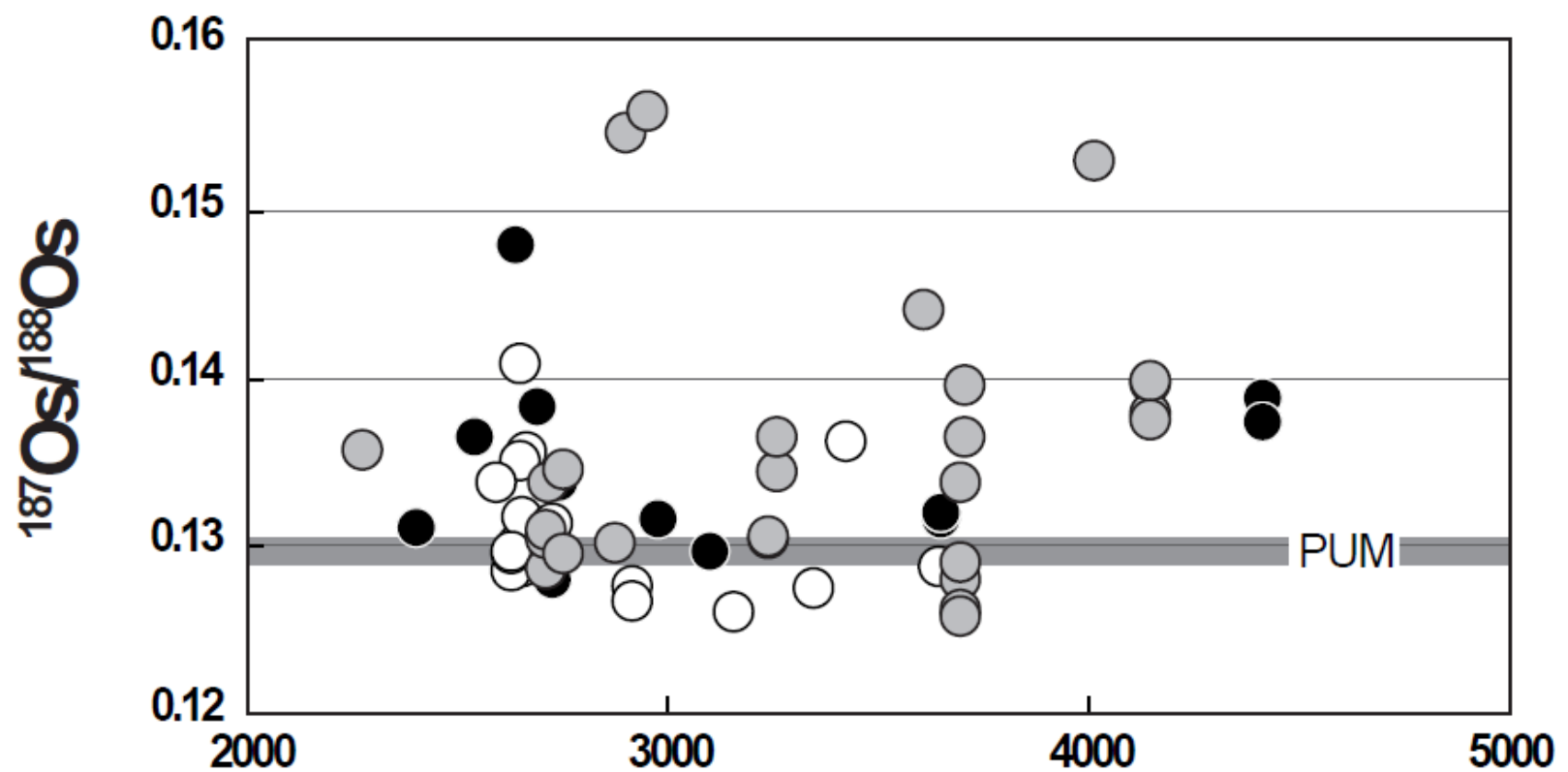

3497 
3528

3529

Figure 16

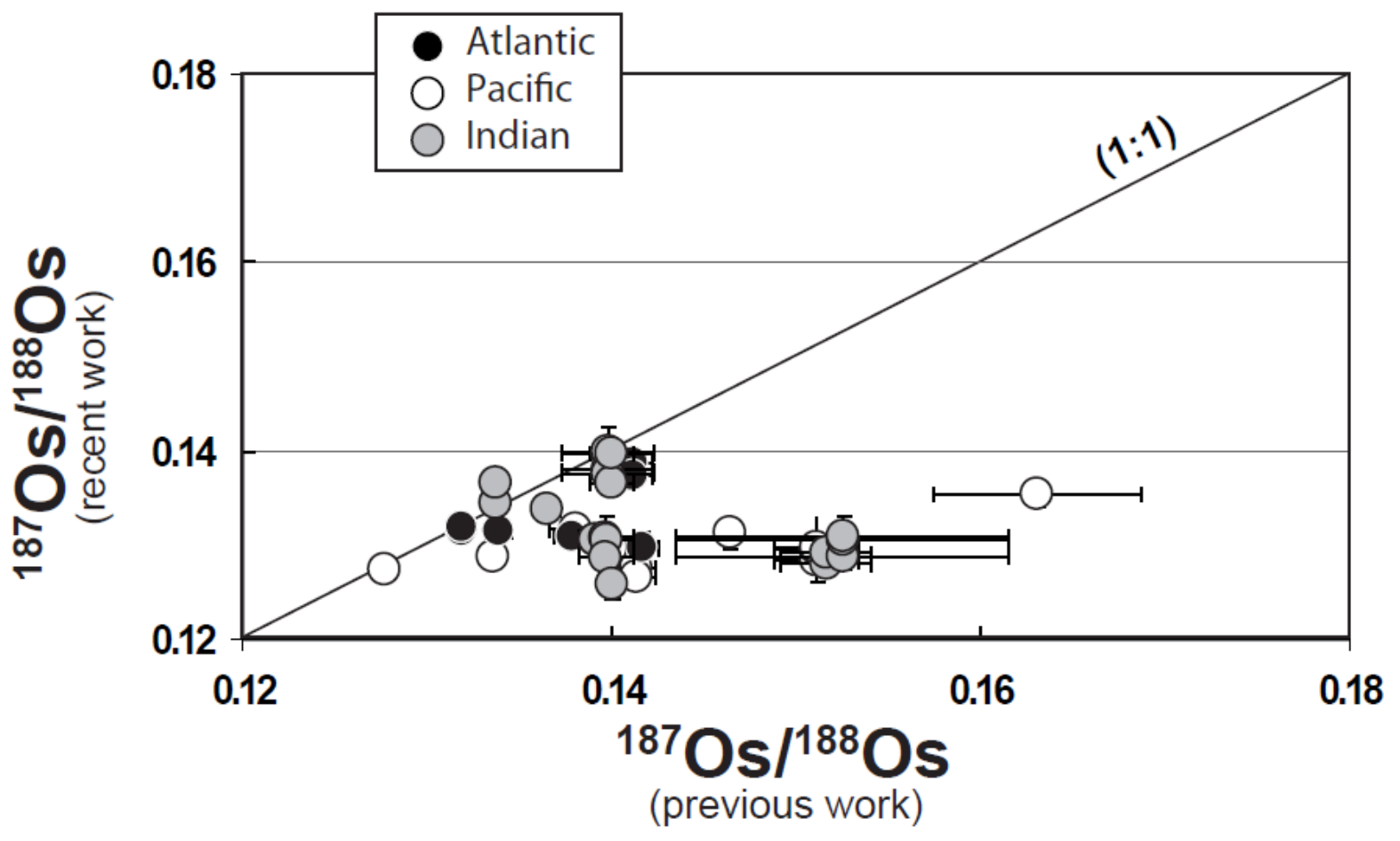

3530

3531

3532

3533

3534

3535

3536

3537

3538

3539

3540

3541

3542

3543

3544

3545

3546

3547

3548

3549

3550

3551

3552

3553

3554 
3558

3559

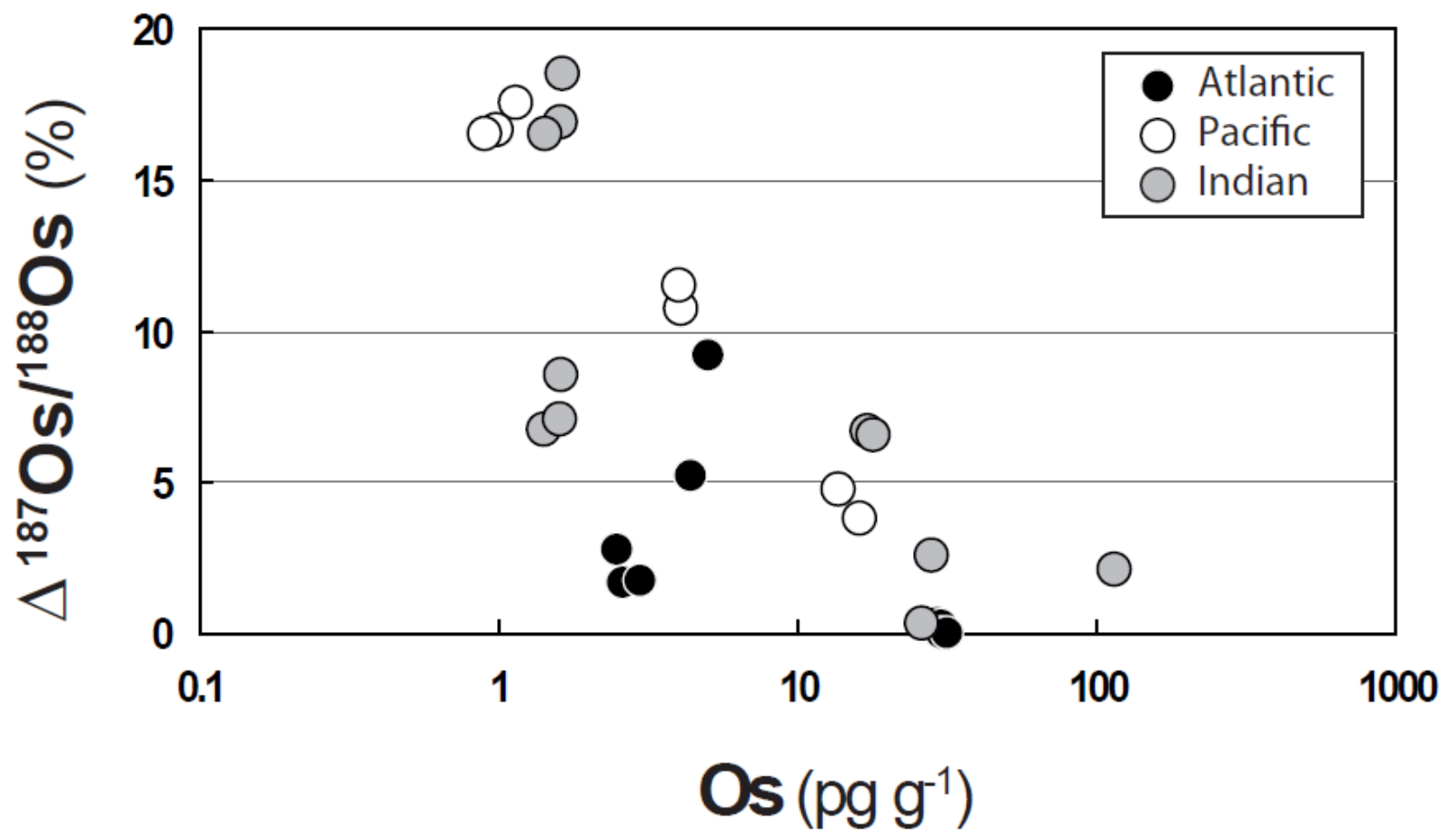

3560

3561

3562

3563

3564

3565

3566

3567

3568

3569

3570

3571

3572

3573

3574

3575

3576

3577

3578

3579

3580

3581

3582

3583

3584

3585

3586

3587 
3588

3589

Figure 18

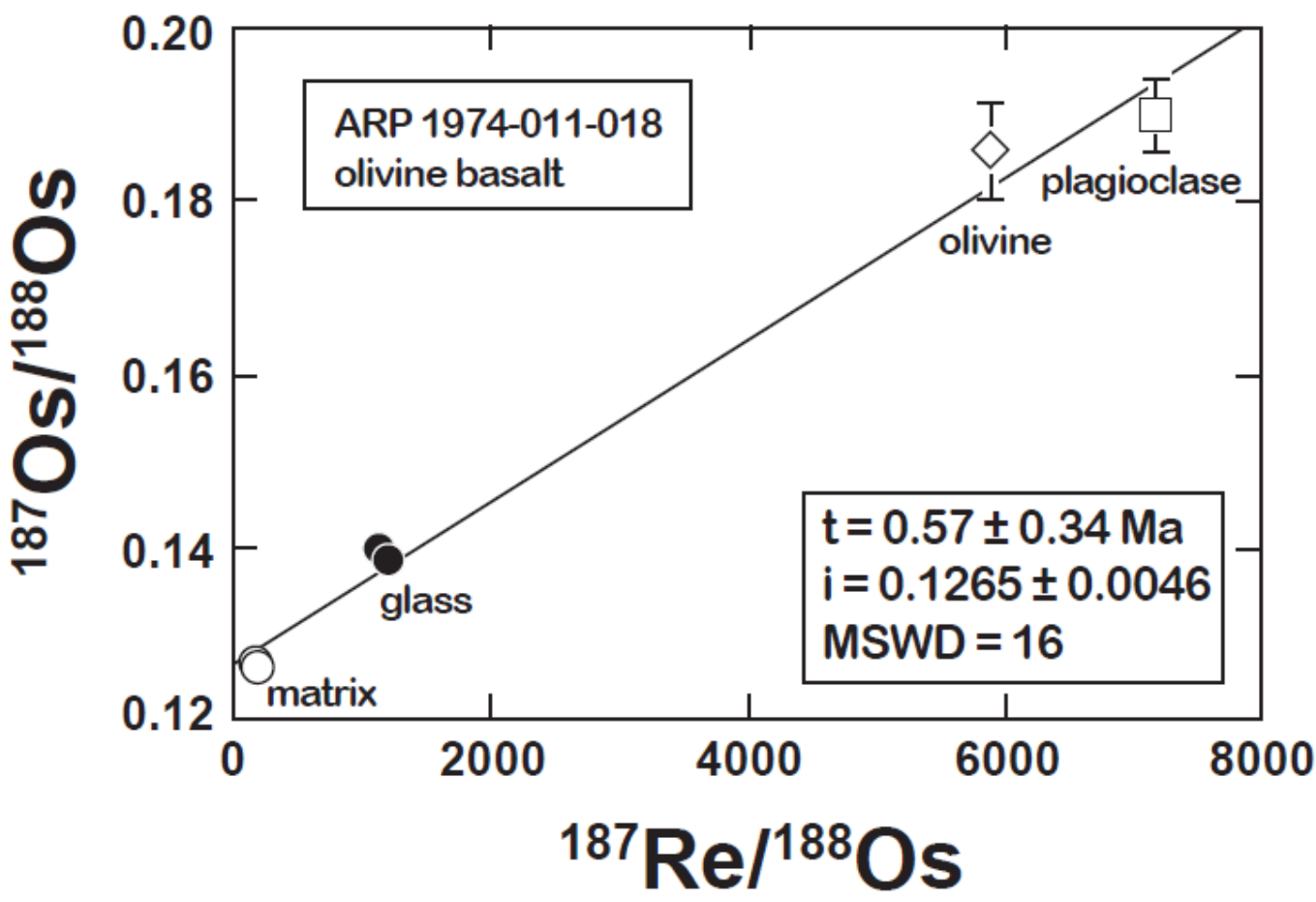


3616

3617
Figure 19

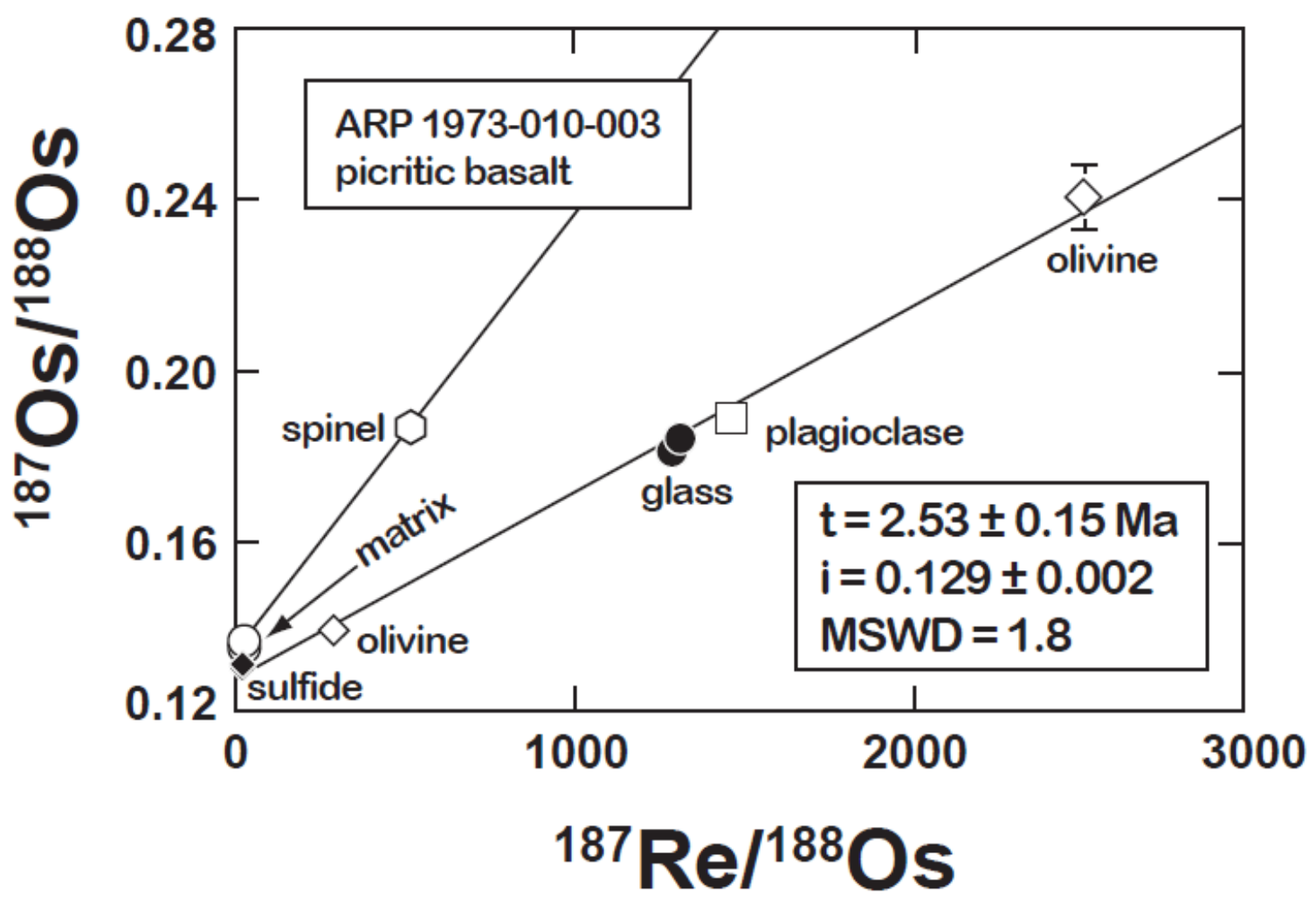


3641

3642
Figure 20

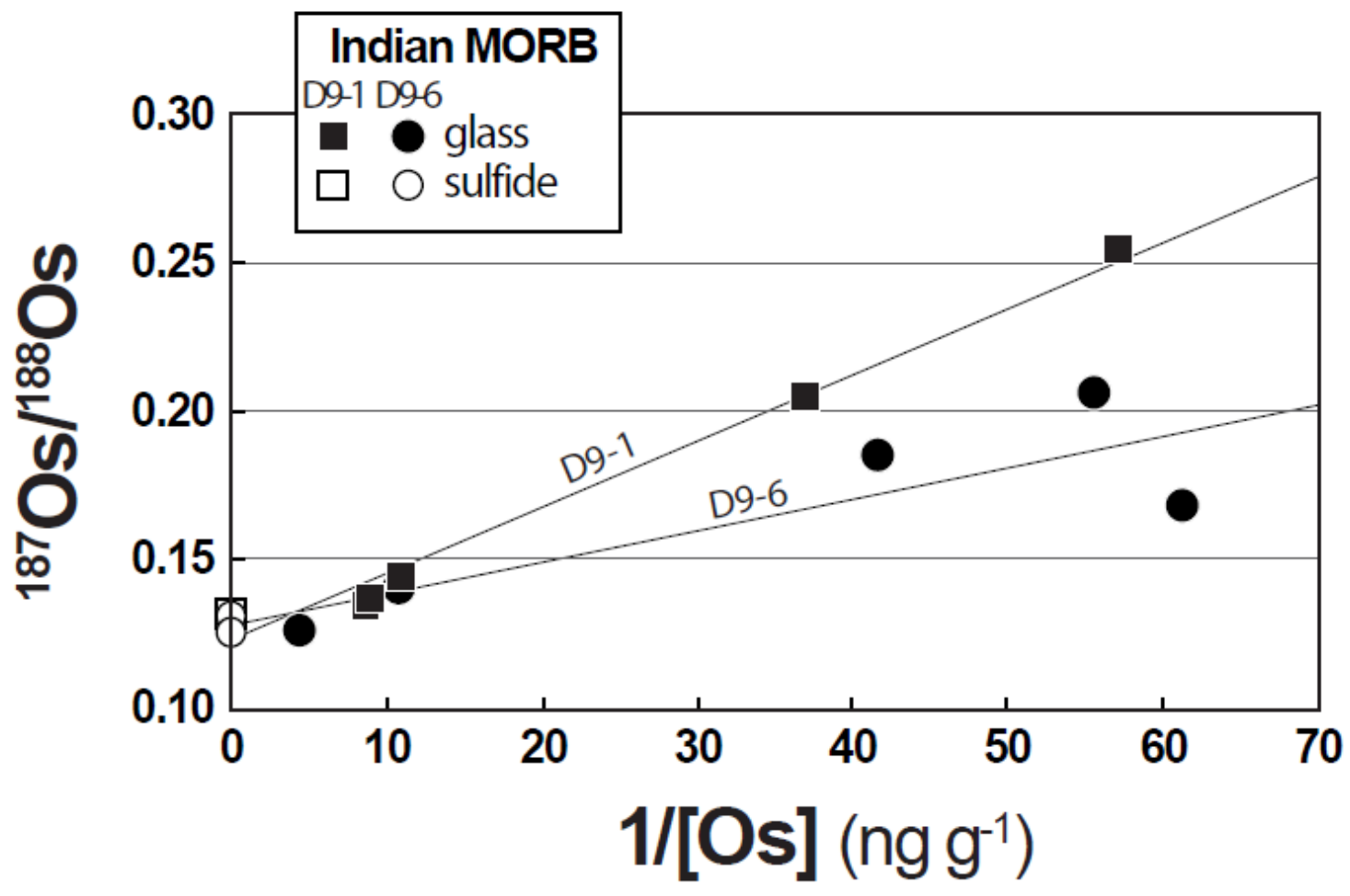

3643 

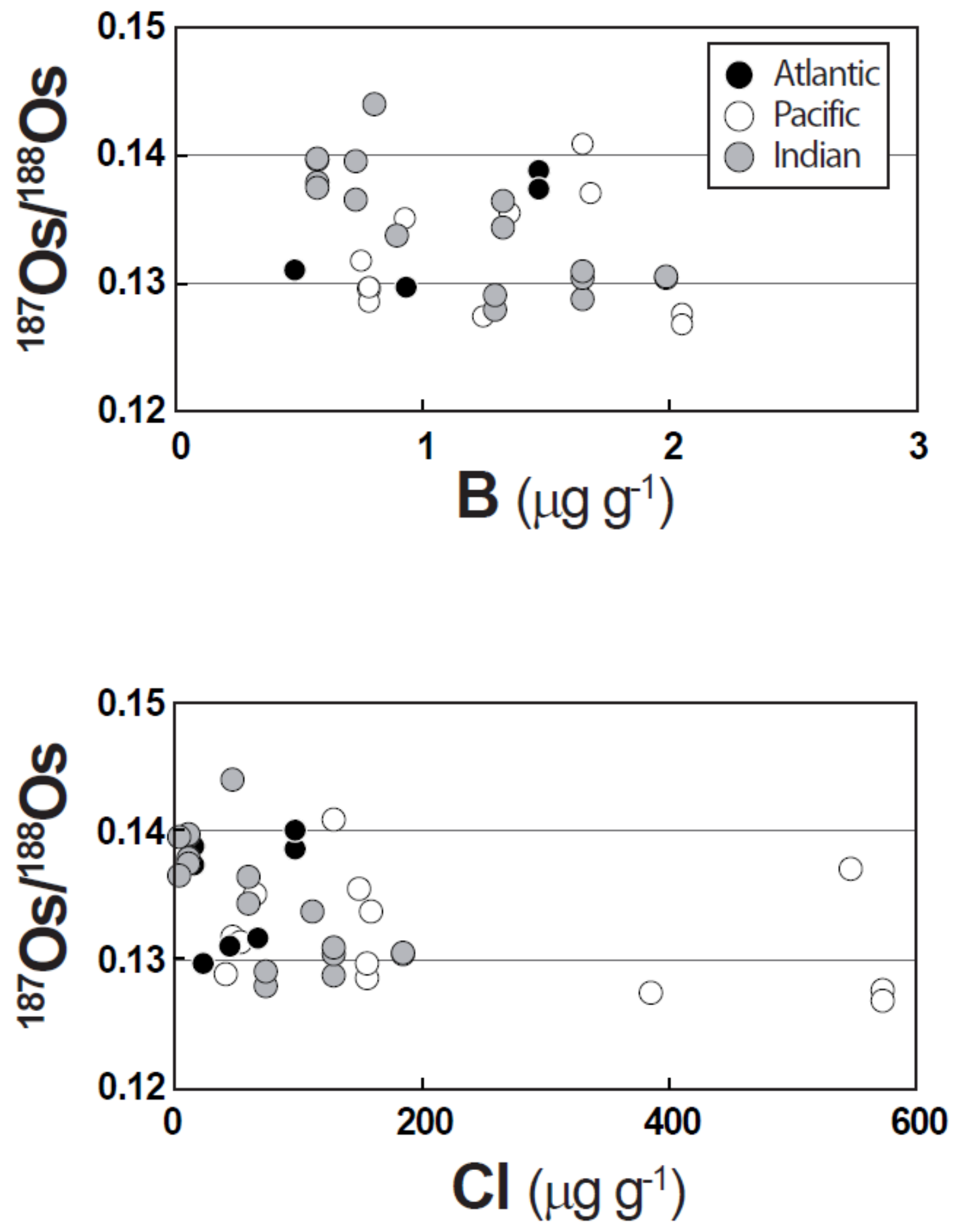
3674

3675
Figure 22

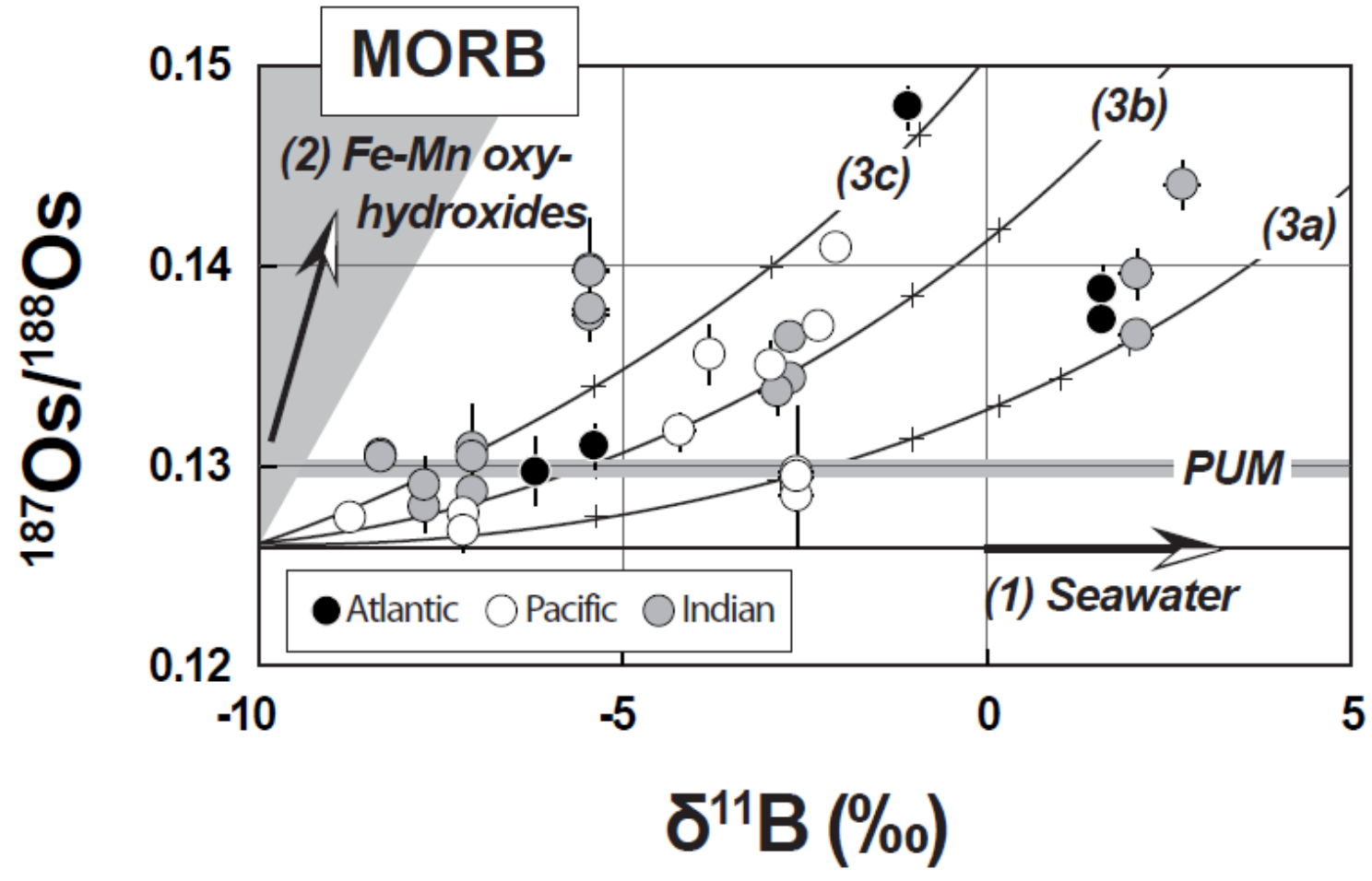



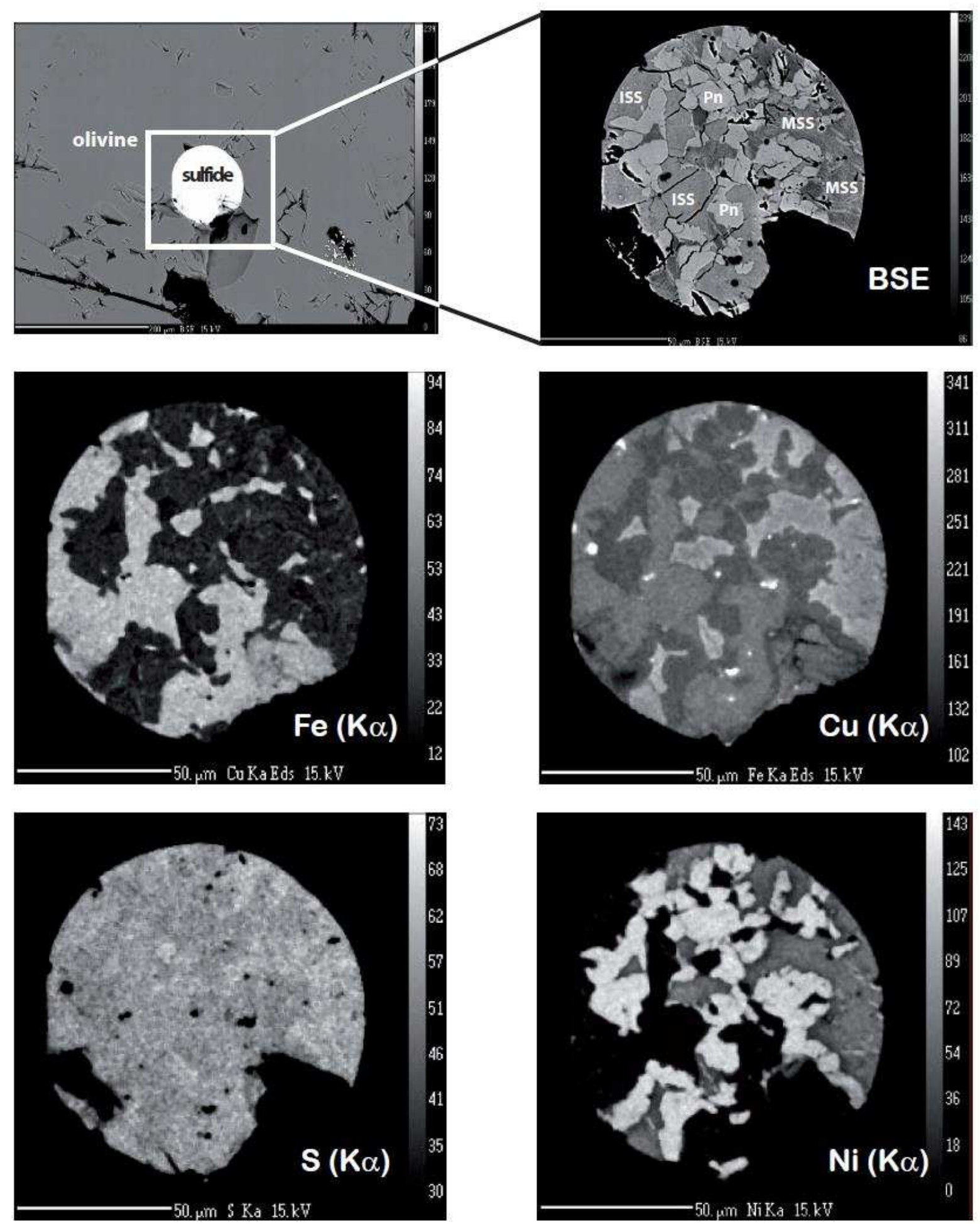
Figure 23b

3708
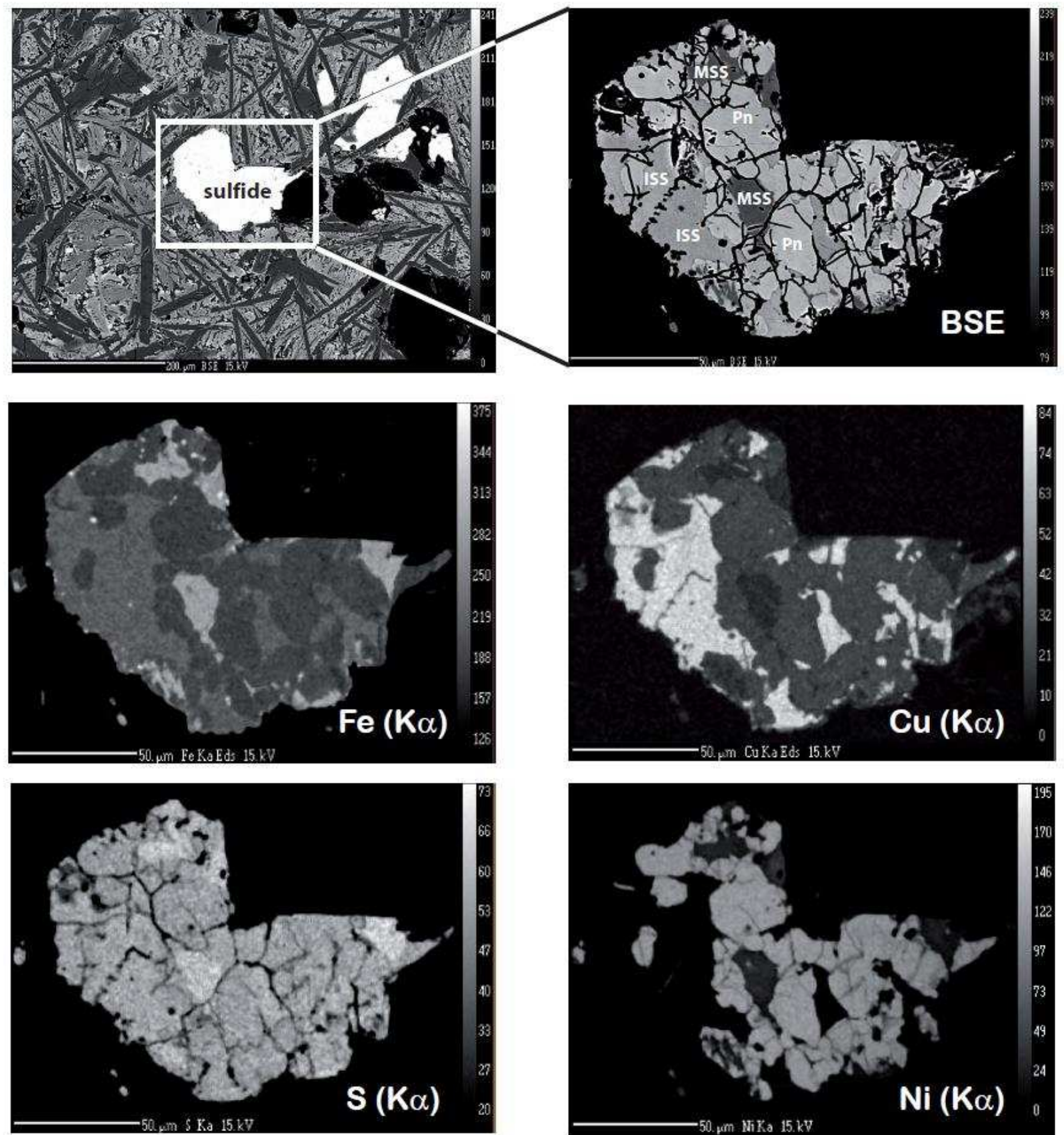


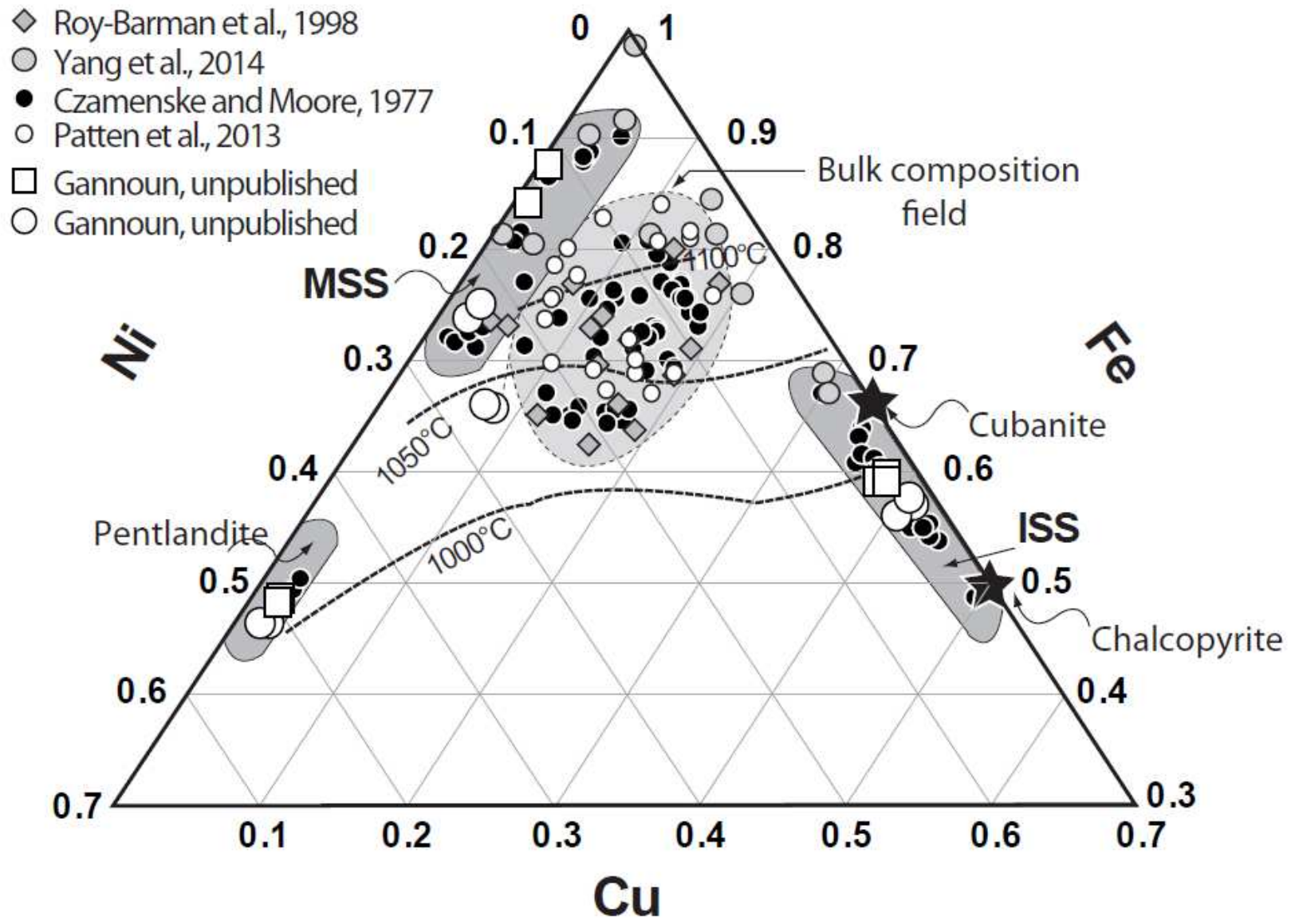




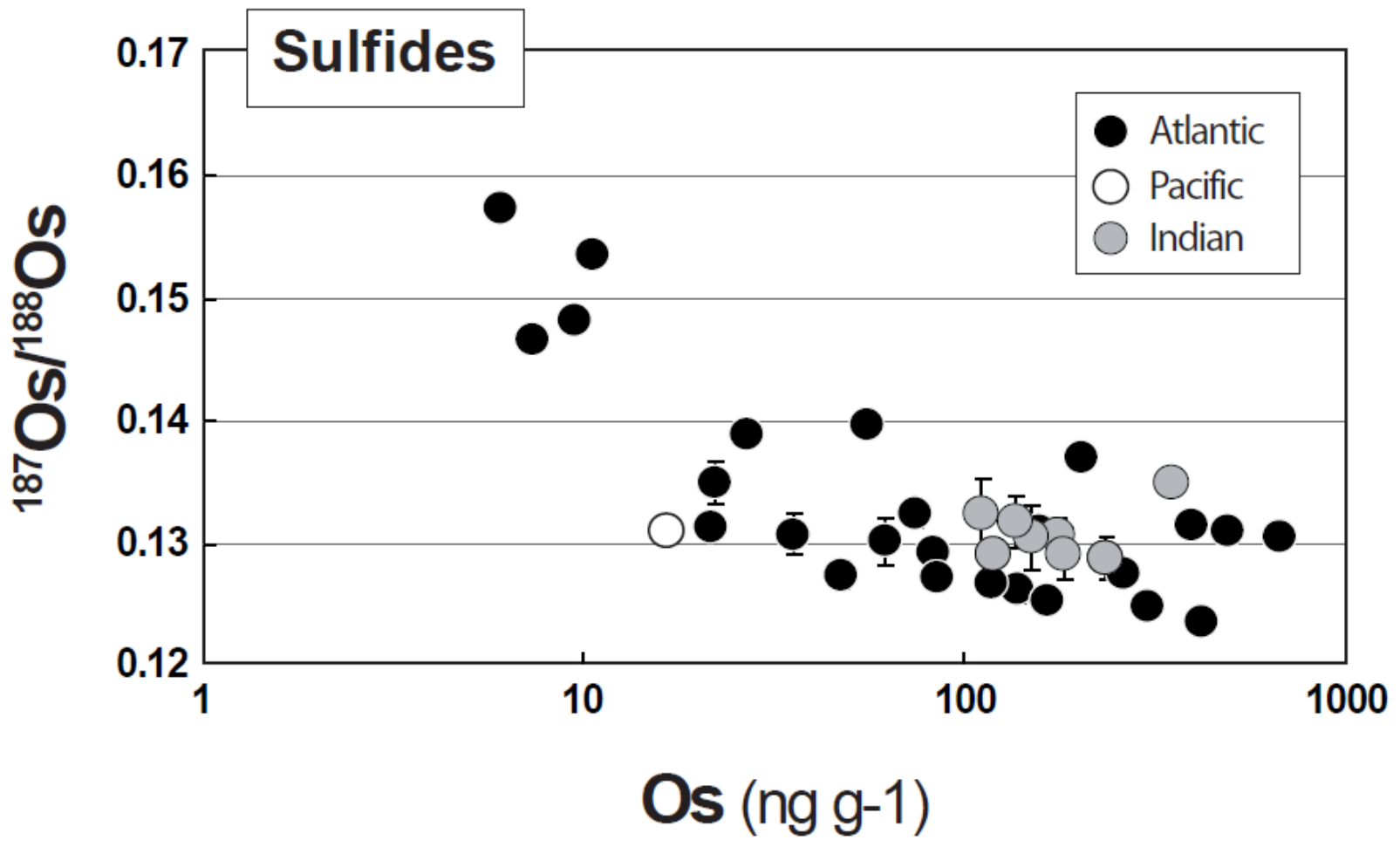


3774

3775

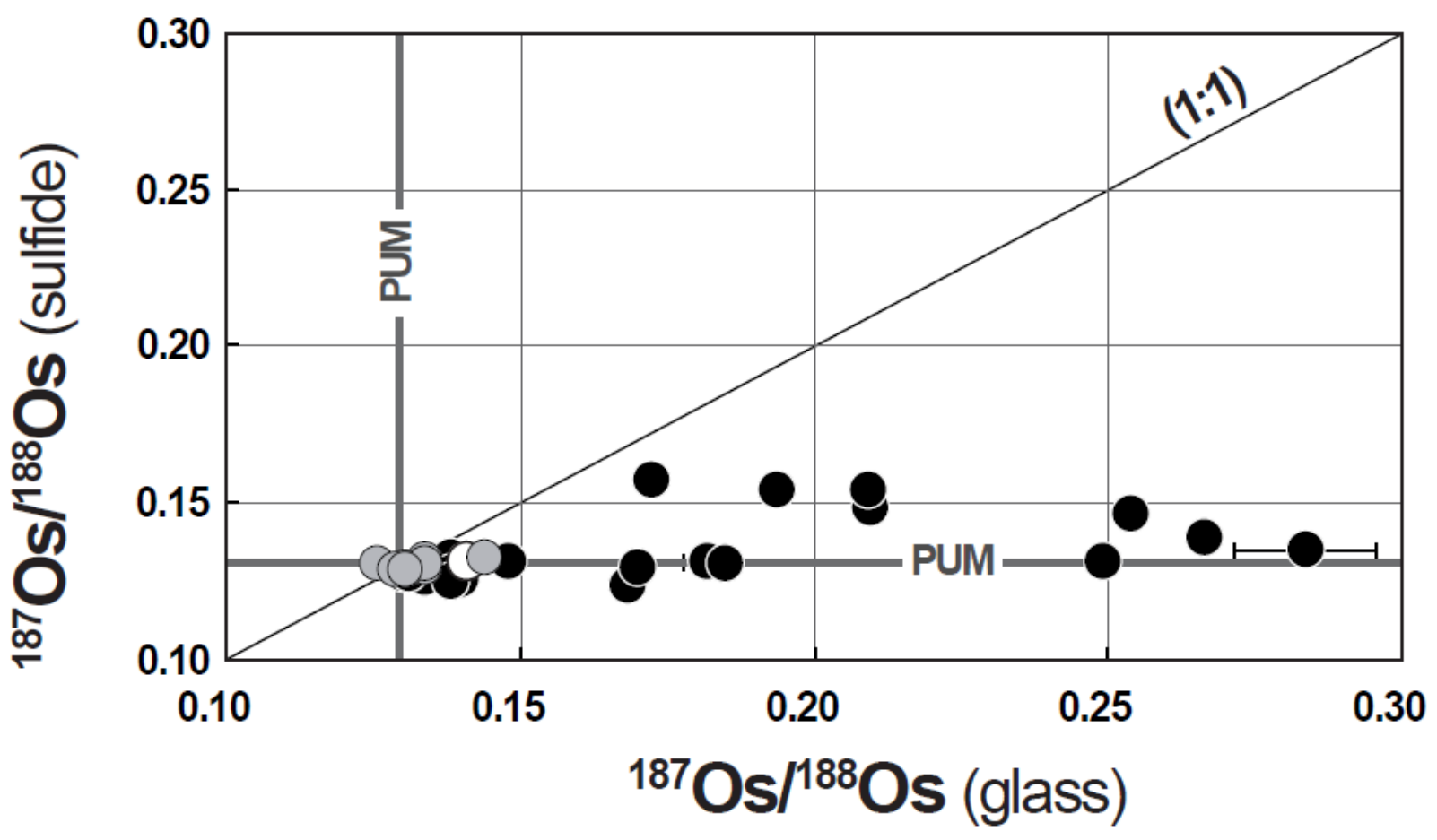

3776

3777

3778

3779

3780

3781

3782

3783

3784

3785

3786

3787

3788

3789

3790

3791

3792

3793

3794

3795

3796

3797

3798

3799

3800

3801

3802 


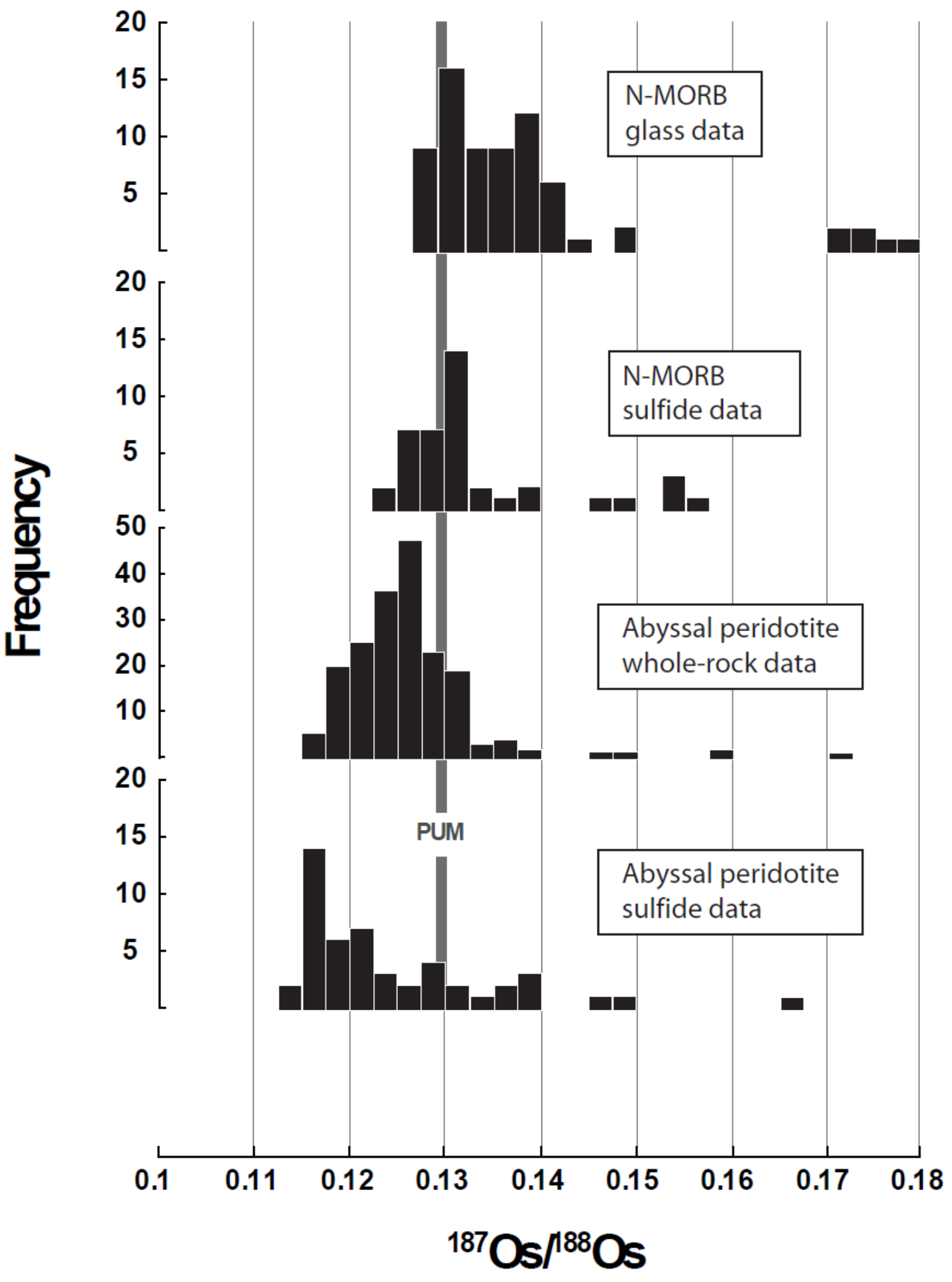


3807

3808

Figure 28

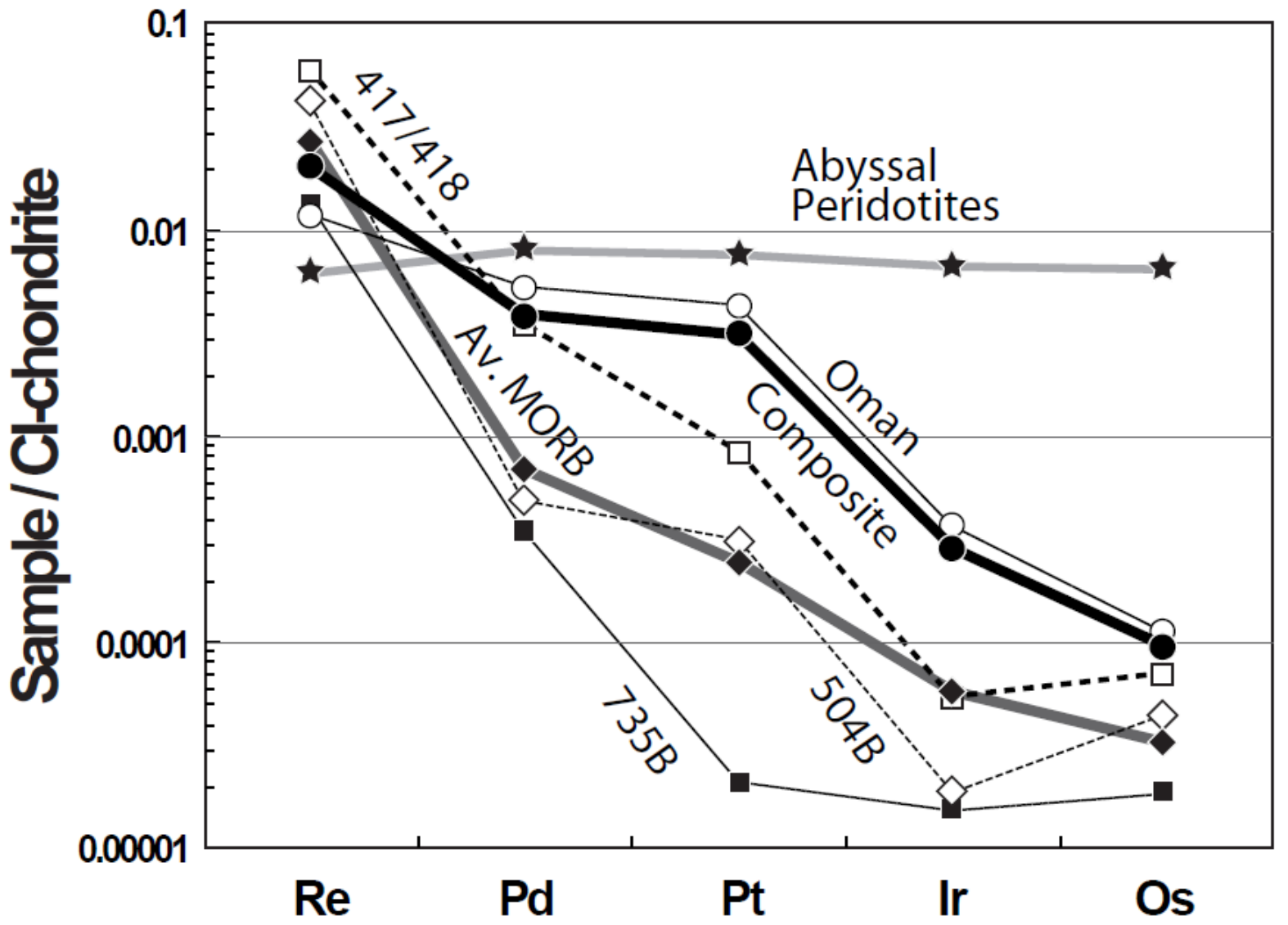

3809

3810

3811

3812

3813

3814

3815

3816

3817

3818

3819

3820

3821

3822

3823

3824

3825

3826

3827

3828

3829

3830 


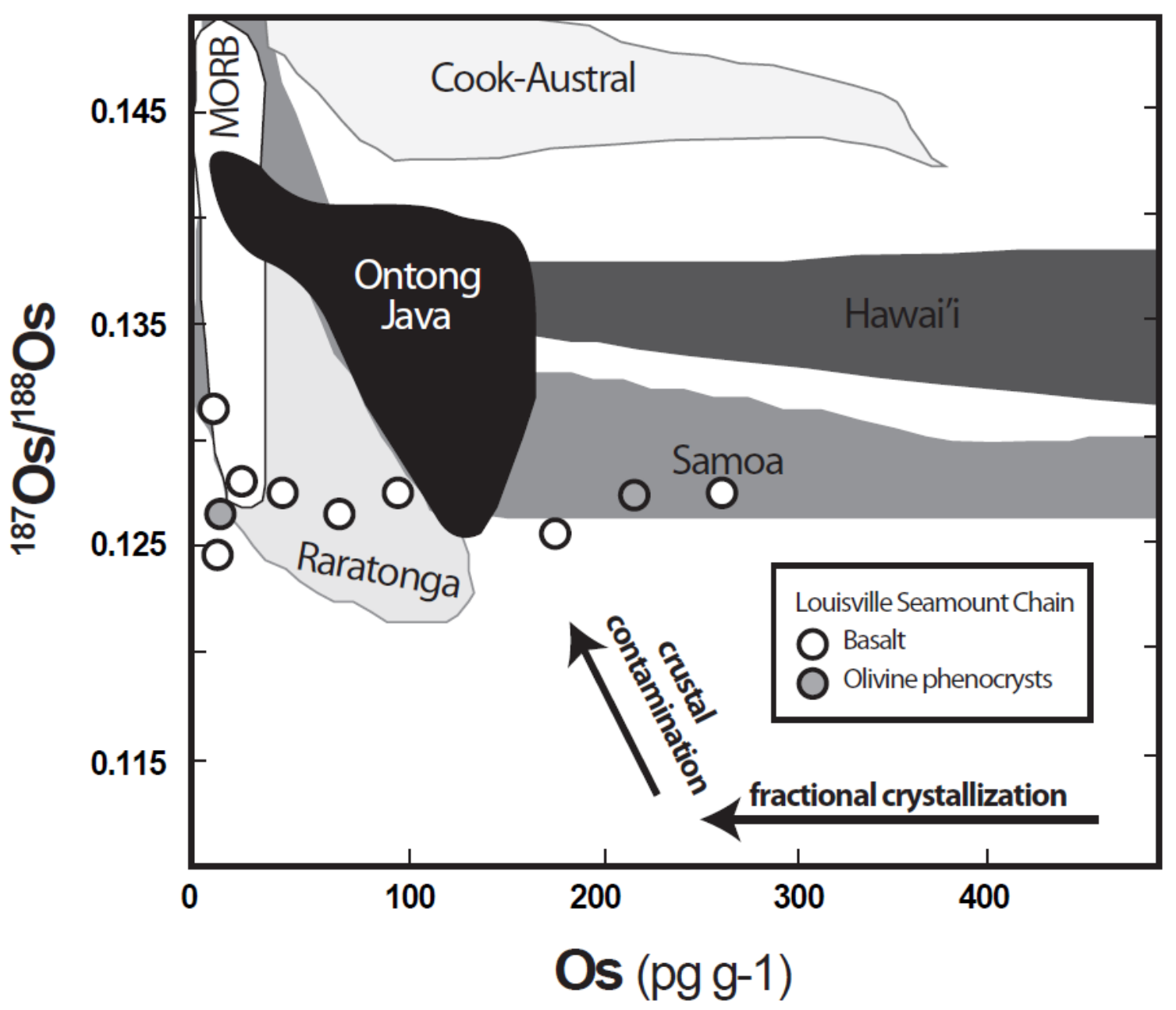


3852

3853

Figure 30
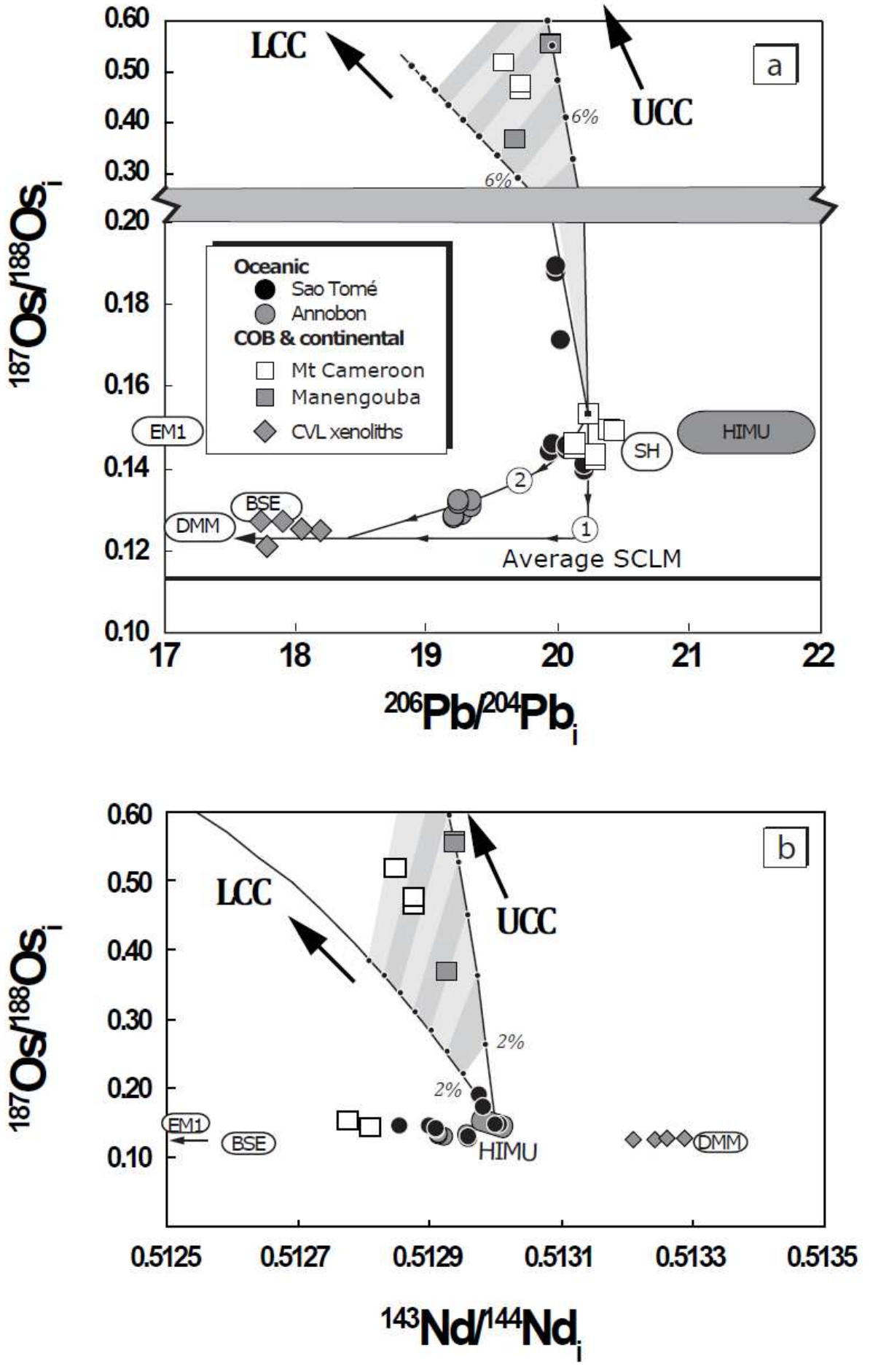
3862

3863

Figure 31

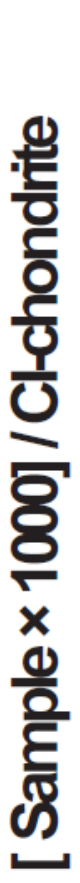

100

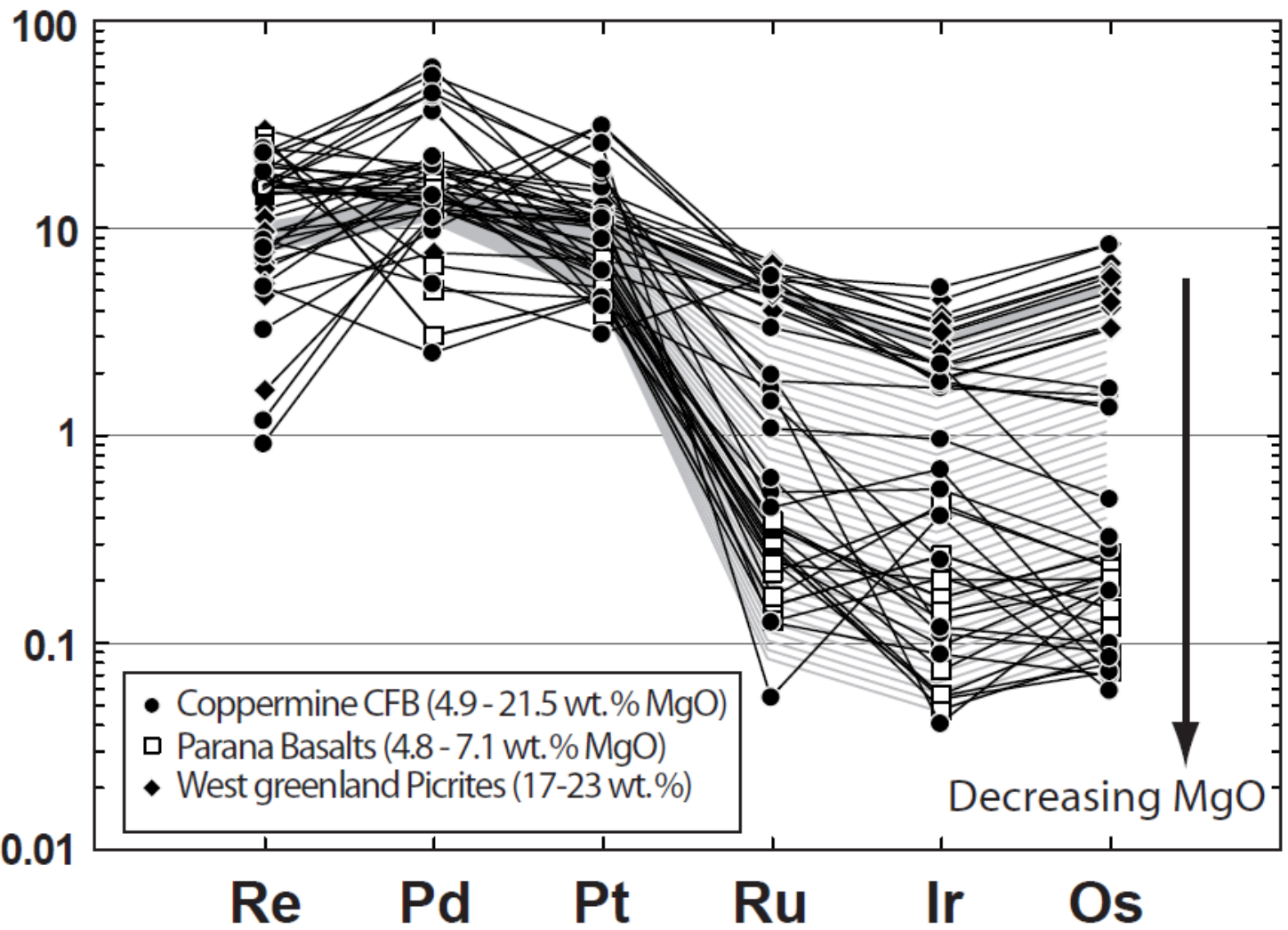

3864

3865

3866

3867

3868

3869

3870

3871

3872

3873

3874

3875

3876

3877

3878

3879

3880

3881

3882

3883

3884

3885

3886

3887 


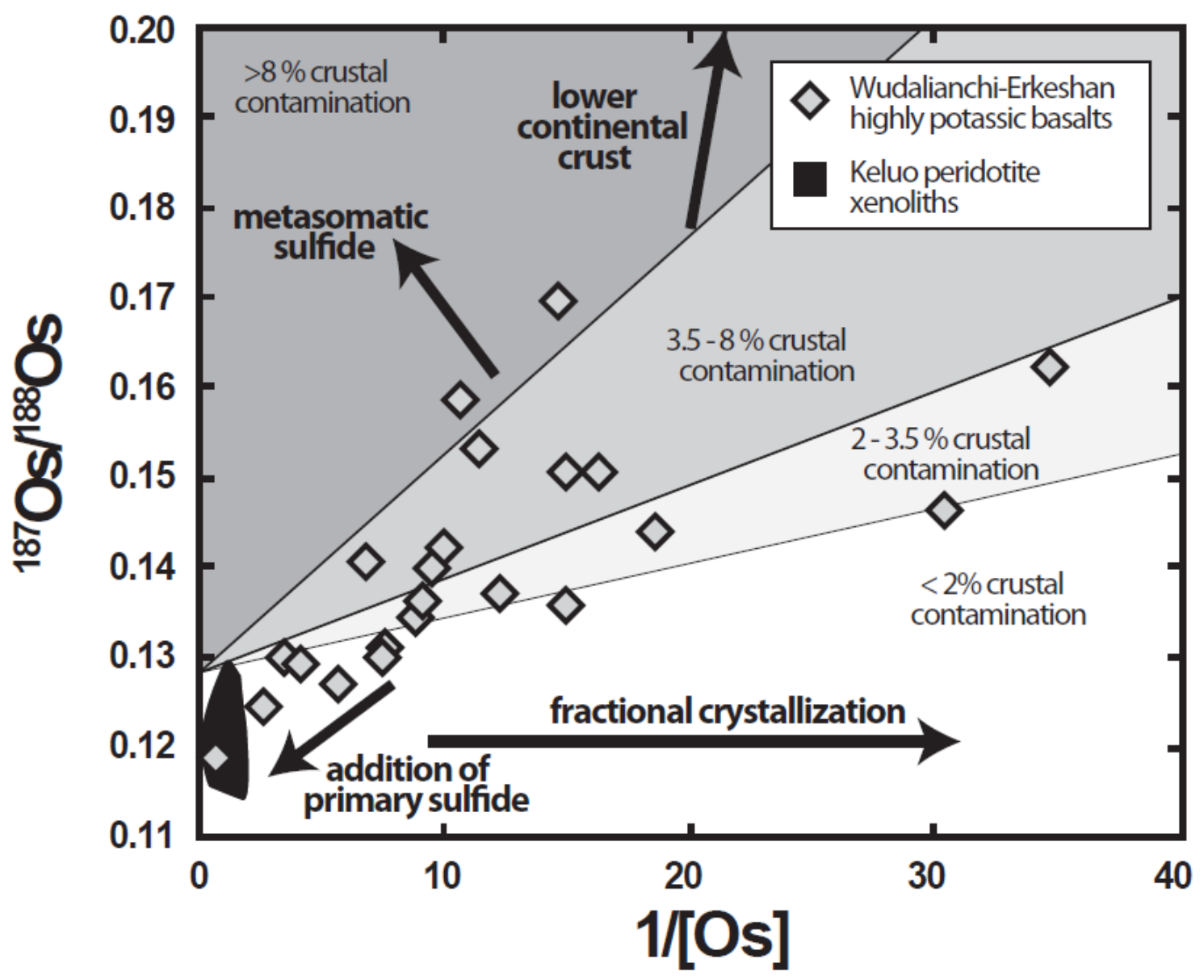




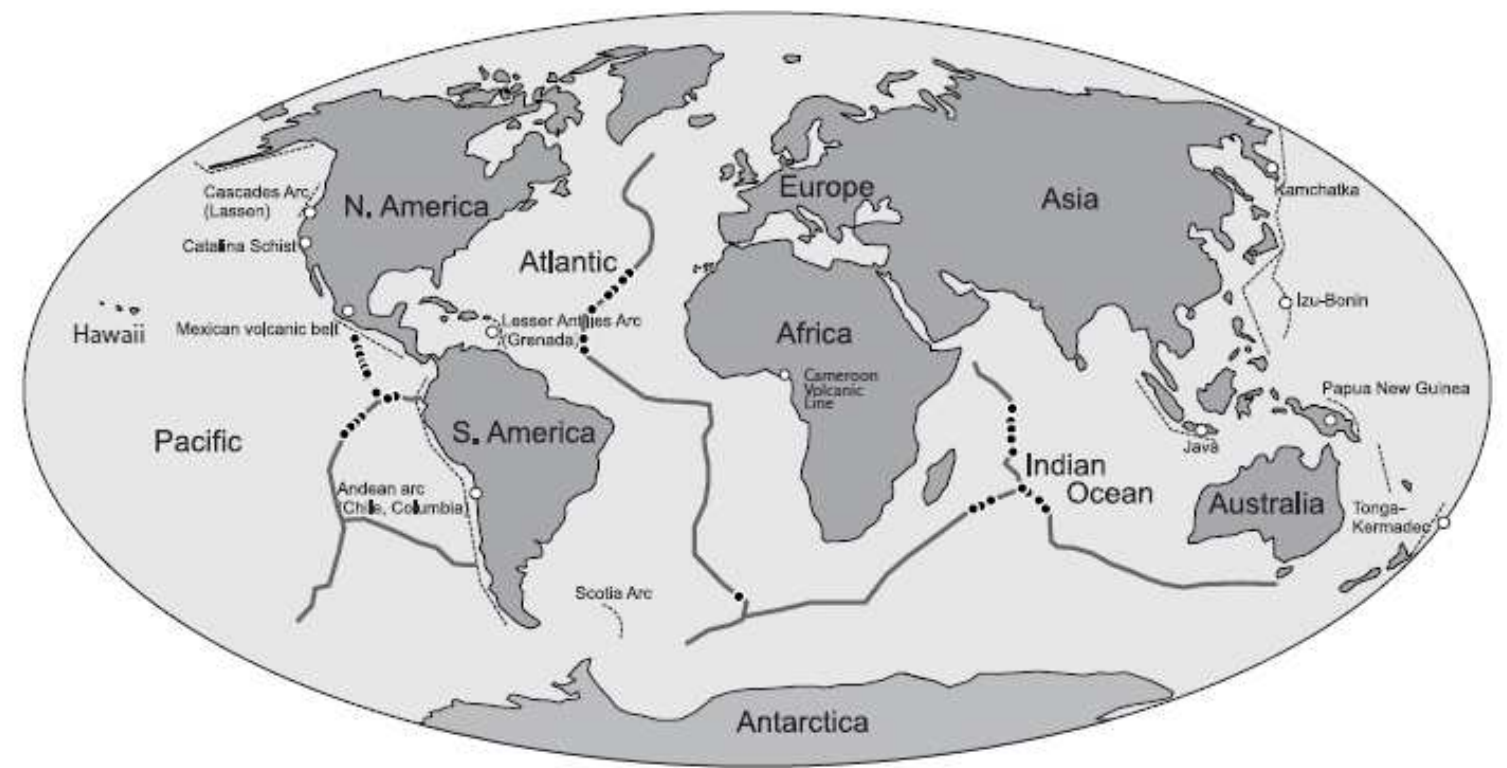

3912

3913

3914

3915

3916

3917

3918

3919

3920

3921

3922

3923

3924

3925 
3942 Figure 34

3943
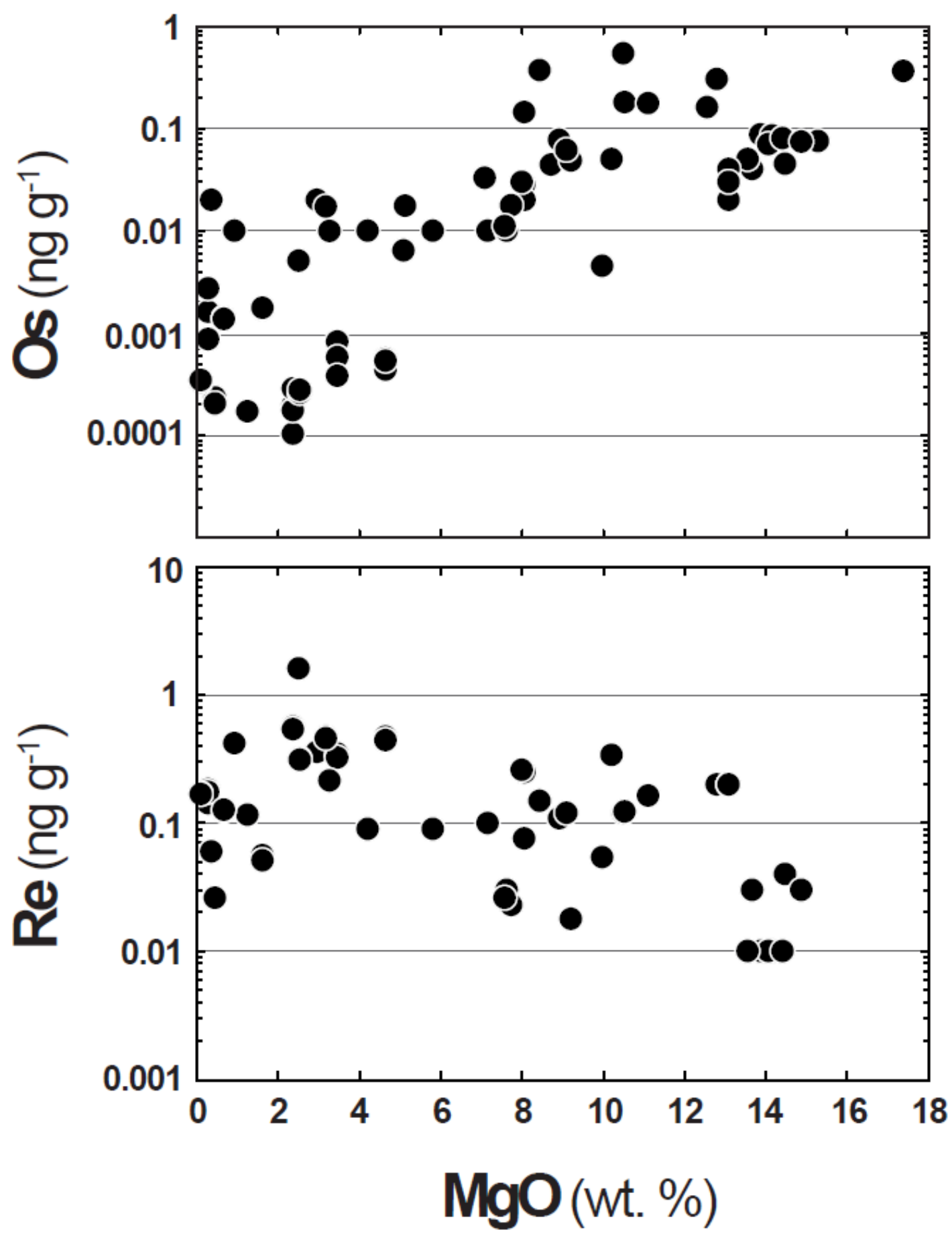

3944

3945

3946

3947

3948

3949

3950 
3951 Figure 35

3952 

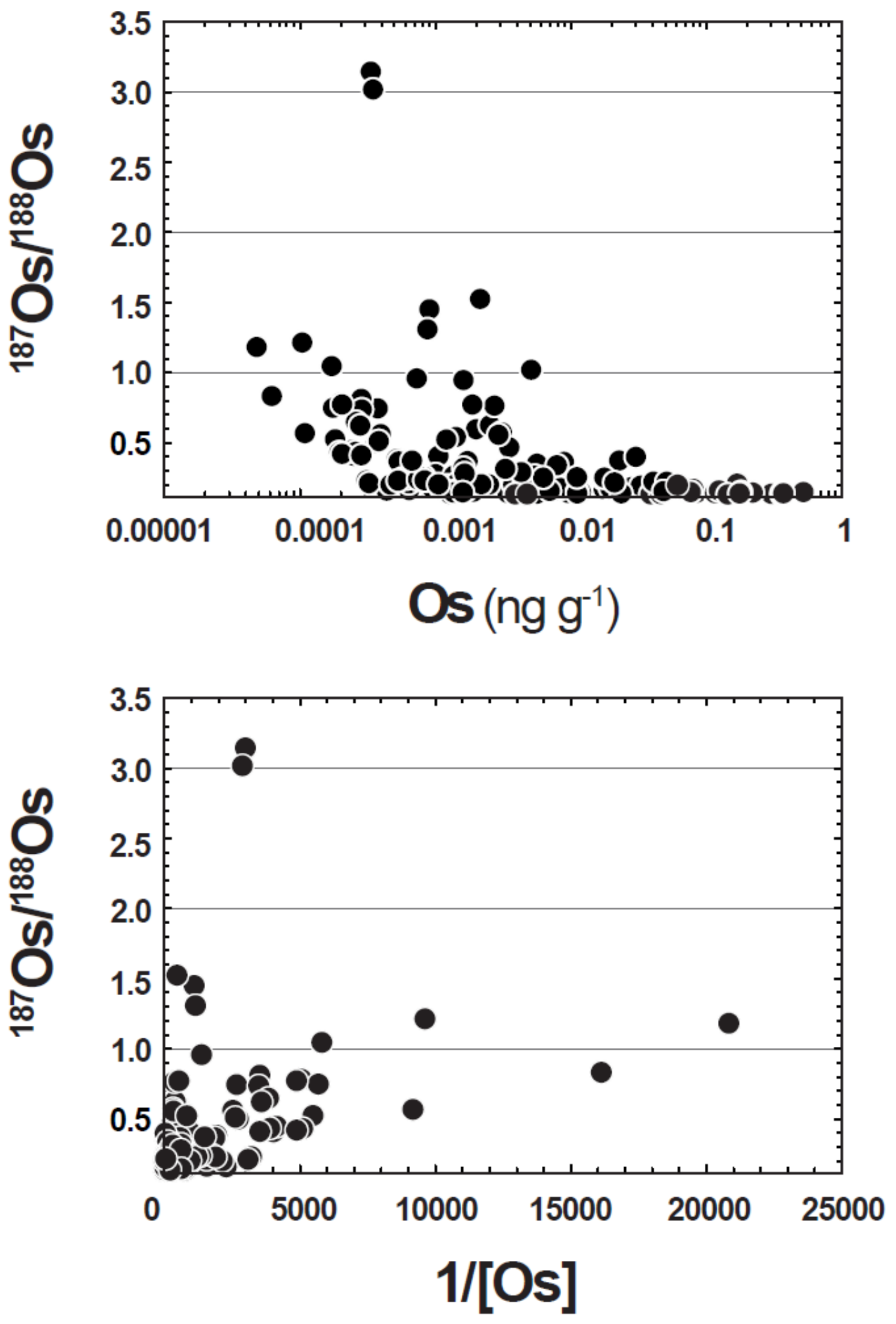
3954 3955

3956

3957

3958

3959

3960

3961

3962

3963

3964

3965

3966

3967

3968

3969

3970

3971

3972

3973

3974

3975

3976

3977

3978

3979

3980

3981

3982

Figure 36
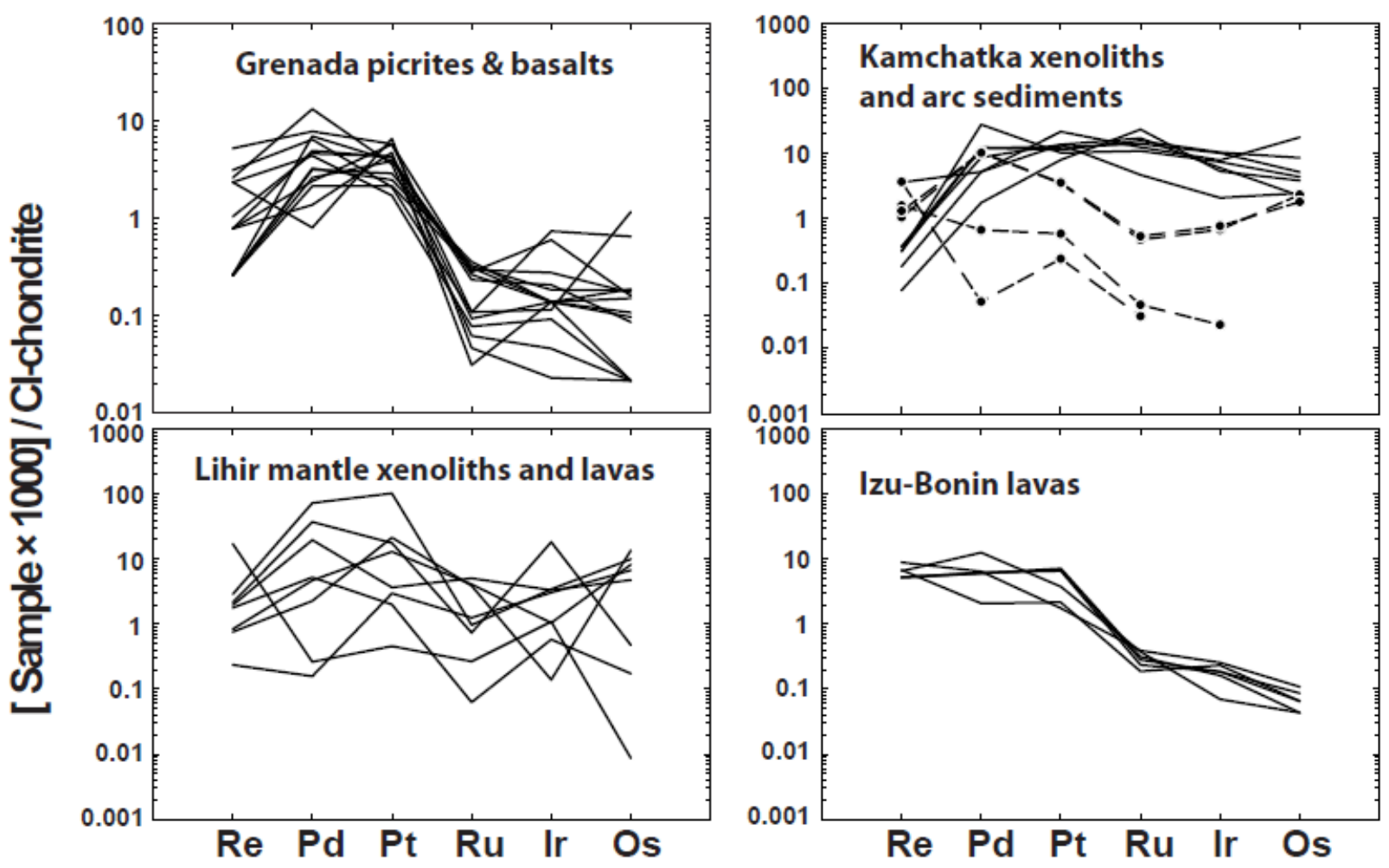

Re Pd Pt Ru Ir Os

6 
3983

3984

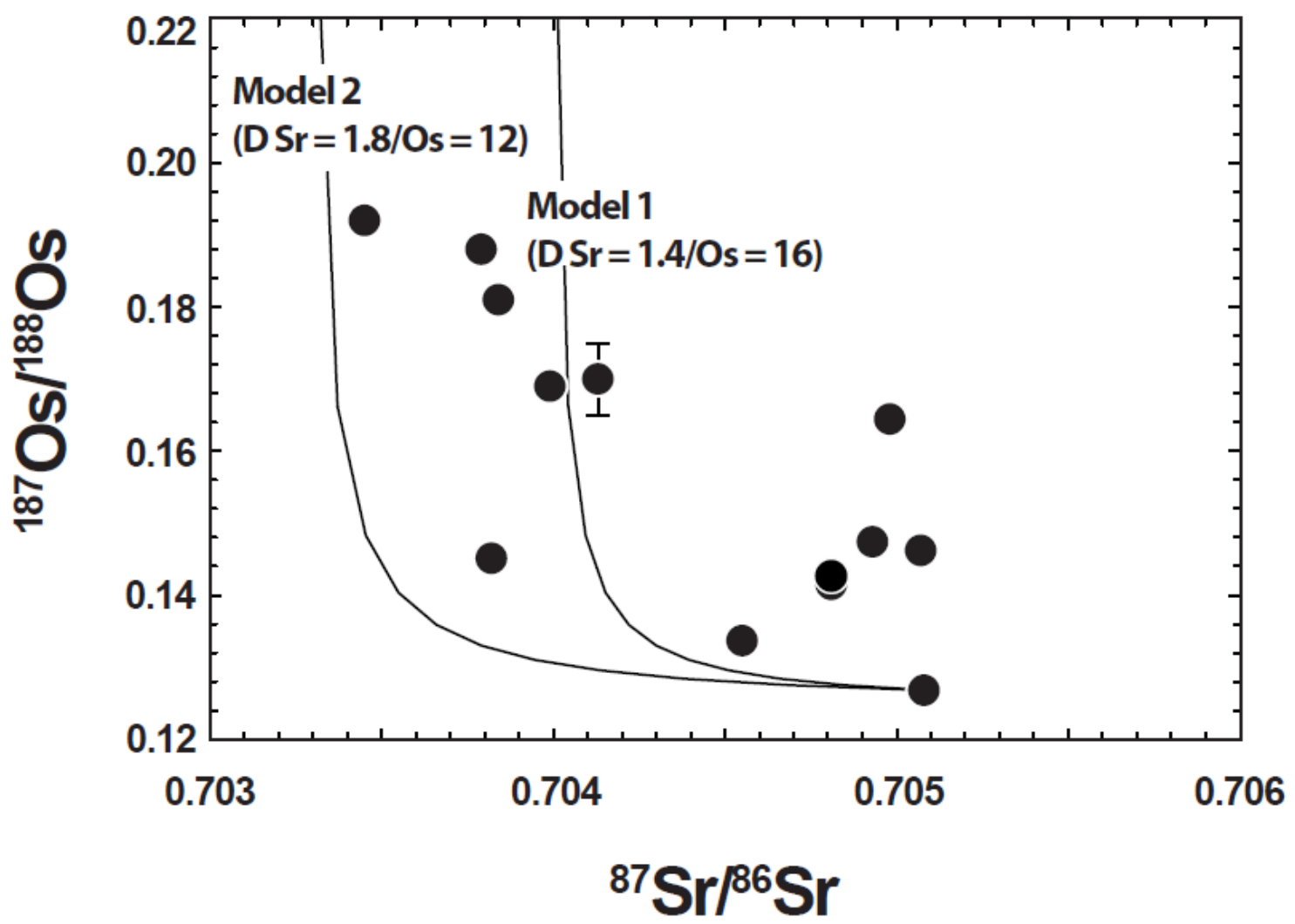

3985

3986

3987

3988

3989

3990

3991

3992

3993

3994

3995

3996

3997

3998

3999

4000

4001

4002

4003

4004

4005

4006 
4007

4008
Figure 38

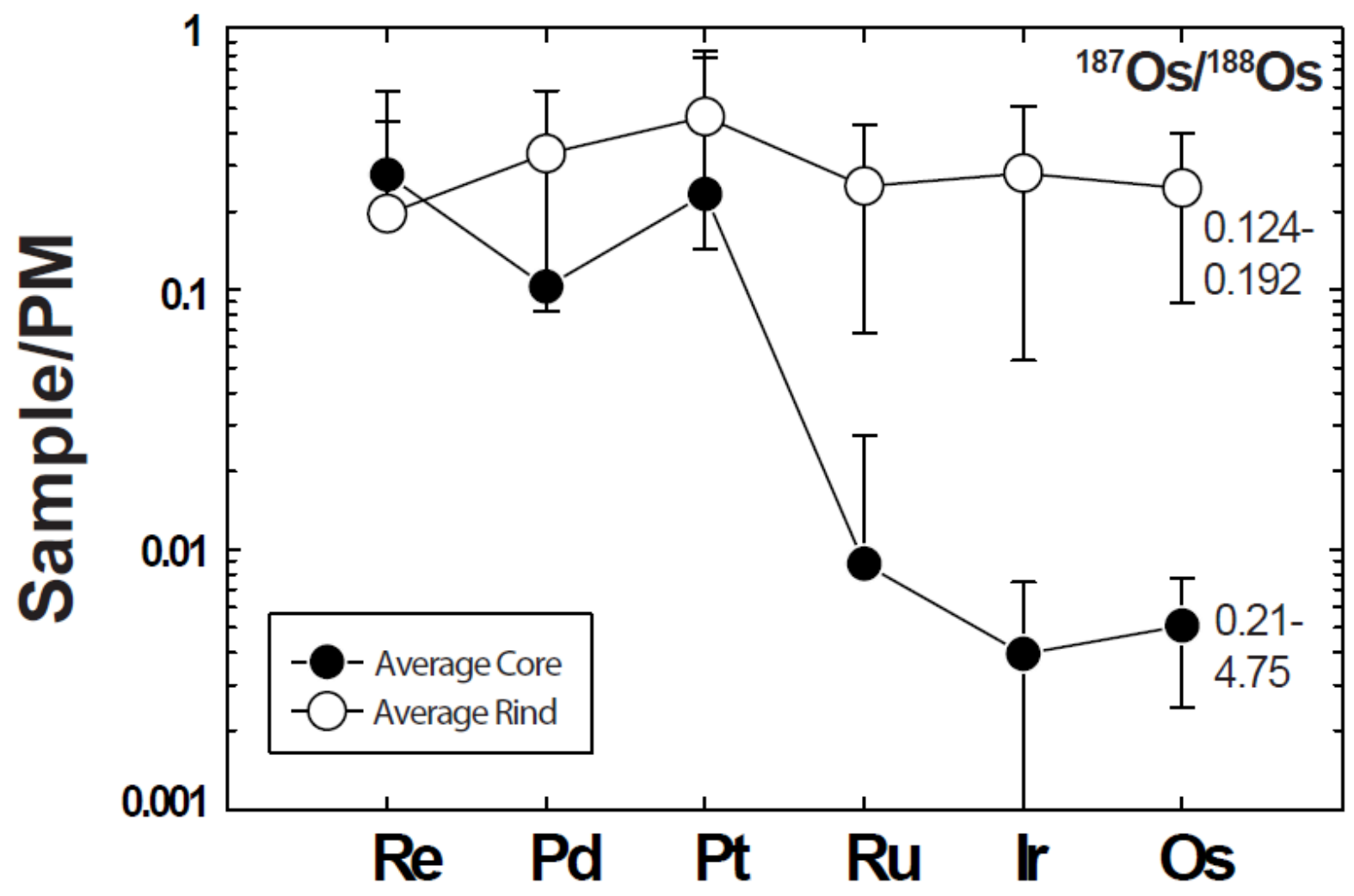

4009

4010

4011

4012

4013

4014

4015

4016

4017

4018

4019

4020

4021

4022

4023

4024

4025

4026

4027

4028

4029

4030

4031 